\title{
Early-Middle Ordovician cephalopods from Ny Friesland, Spitsbergen - a pelagic fauna with Laurentian affinities
}

\author{
Björn KRÖGER ${ }^{\circledR 1, *} \&$ Alexander POHLE ${ }^{\circledR} 2$ \\ ${ }^{1}$ Finnish Museum of Natural History, University of Helsinki, PO Box 44, FI-00014 Helsinki, Finland. \\ ${ }^{2}$ Paläontologisches Institut und Museum, University of Zurich, Zurich, Switzerland. \\ *Corresponding author: bjorn.kroger@helsinki.fi \\ ${ }^{2}$ Email: alexander.pohle@pim.uzh.ch \\ ${ }^{1}$ urn:1sid:zoobank.org:author:72F166B6-51DC-4DD8-9DEE-47EDDEE3D2F2 \\ ${ }^{2}$ urn:1sid:zoobank.org:author:9C9B621D-7A77-41FF-8B63-DD21BEE10B56
}

\begin{abstract}
The collection of cephalopods from eight sampling horizons within the Olenidsletta Member, Valhallfonna Formation, Floian-Dapingian, from Profilstranda and nearby Profilbekken, Ny Friesland, Spitsbergen, resulted in the detection of 31 species, 20 genera, and 12 families from the Ellesmerocerida, Endocerida, Riocerida, Dissidocerida, Orthocerida, Tarphycerida, and Oncocerida. Of these, five genera (Ethanoceras gen. nov., Hinlopoceras gen. nov., Nyfrieslandoceras gen.nov., Olenidslettoceras gen. nov., Svalbardoceras gen. nov.) and 19 species (Bactroceras fluvii sp. nov., Buttsoceras buldrebreenense sp. nov., Cycloplectoceras hinlopense sp. nov., Cyclostomiceras profilstrandense sp. nov., Deltoceras beluga sp. nov., Eosomichelinoceras borealis sp. nov., Ethanoceras solitudines gen. et sp. nov., Hemichoanella occulta sp. nov., Hinlopoceras tempestatis gen. et sp. nov., H. venti gen. et sp. nov., Lawrenceoceras ebenus sp. nov., L. larus sp. nov., Litoceras profilbekkenense sp. nov., Nyfrieslandoceras bassleroceroides gen. et sp. nov., Olenidslettoceras farmi gen. et sp. nov., Protocycloceras minor sp. nov., Proterocameroceras valhallfonnense sp. nov., Svalbardoceras sterna gen. et sp. nov., S. skua gen. et sp. nov.) are new. The diagnoses of the Cyptendoceratidae, Bactroceratidae and of Deltoceras Hyatt, 1894 are emended. Well preserved early growth stages in several species are remarkable. Turnover between the sampling horizons and between sampling intervals is high. The differences in composition, diversity and evenness of the assemblages are interpreted as reflecting changing depth and oxygenation depositional bottom conditions. The co-occurrence of endemic and cosmopolitan species is interpreted as resulting from a high vertical niche differentiation and from eustatically generated lateral shifts of facies zones. Based on calculations of phragmocone implosion depths, depositional depths of 50-130 m are plausible for the Olenidsletta Member, supporting independent evidence from biomarker signatures. Several cephalopod species of the Olenidsletta Member represent odd mosaics of morphological features of previously known cephalopods which cannot be unambiguously assigned to one of the existing cephalopod higher taxa. Results from a cladistic analysis shed new light on the early evolution of the Oncocerida and Orthocerida.
\end{abstract}

Keywords. Depositional depth, Laurentia, Cephalopoda, palaeoecology, palaeogeography, pelagic niche differentiation, protoconch. 
Kröger B. \& Pohle A. 2021. Early-Middle Ordovician cephalopods from Ny Friesland, Spitsbergen - a pelagic fauna with Laurentian affinities. European Journal of Taxonomy 783: 1-102.

https://doi.org/10.5852/ejt.2021.783.1601

\section{Introduction}

The strata of the Valhallfonna Formation, Spitsbergen are unique, because they contain an exceptionally rich shelly fossil fauna of both bottom dwellers and free swimmers from the end of the Early to the Middle Ordovician Period. The transition from the Early to Middle Ordovician is associated with a drastic global diversification of graptolites (Cooper et al. 2014), with major faunal changes among trilobites (Adrain et al. 2004), and with massive shifts in the abundance pattern of skeletal faunal components in Laurentian sediments (Li \& Droser 1999; Finnegan \& Droser 2005; Pruss et al. 2010). The late Early Ordovician is also the time that sets the stage for the main phase of the Ordovician radiation during the Middle Ordovician (Rasmussen et al. 2019; Stigall et al. 2019). Rising atmospheric oxygen levels, the associated oxygenation of the water column, and changes in the availability of trophic resources are potentially major factors behind these ecological shifts (Servais et al. 2008; Trotter et al. 2008; Pruss et al. 2010; Cooper et al. 2012b; Rasmussen et al. 2019; Goldberg et al. 2021).

The lower member of the formation, the Olenidsletta Member, represents a distal depositional environment with predominantly dark-shales of oxygen-depleted bottom conditions and with intermittent, partly bioturbated limestone intervals containing a remarkably rich fauna of trilobites (Fortey 1974, 1975b, 1980; Hopkins 2019), brachiopods (Hansen \& Holmer 2010, 2011) and graptolites (Cooper \& Fortey 1982). A study of the sediments of the formation and its fossils, therefore, can provide valuable information on the structure of this pelagic ecosystem and its geological change at the dawn of the Ordovician radiation.

Cephalopods are an abundant skeletal component in several horizons of the Olenidsletta Member. However, until now only two species with limited stratigraphic information have been described (Evans \& King 1990; Evans 2005). Cephalopods are crucially important for the understanding of the eco-evolutionary shifts within the original water column because they had well constrained nektobenthic to pelagic lifestyles and water depth ranges (e.g., Westermann 1998). A thorough description and palaeoecological analysis of the cephalopods of the Olenidsletta Member is therefore overdue.

\section{Material and methods}

\section{Geological setting}

The Valhallfonna Formation is part of the Oslobreen Group, Hinlopenstretet Supergroup (Harland et al. 1966; Fortey \& Bruton 1973; Harland 1997), and exposed at the northeastern edge of Ny Friesland on the island of Spitsbergen, Svalbard archipelago, Norway, adjacent to the Hinlopen Strait (Hinlopenstretet), which divides Spitsbergen from Nordaustlandet (Fig. 1). Structurally, the Oslobreen Group belongs to the Nordaustlandet terranes of eastern Svalbard (Piepjohn et al. 2019).

In tectonic reconstructions of the early Palaeozoic world, these terranes are part of the margin of the Laurentian craton and placed in close proximity to the Franz Joseph allochthon of northeastern Greenland (Smith \& Rasmussen 2008; Cocks \& Torsvik 2011). During the mid-Paleozoic the sediments of the Hinlopenstretet Supergroup underwent minor folding with predominant NNW-SSE strike directions with little or no metamorphosis (Harland 1997; Gee \& Teben'kov 2004).

Lithostratigraphically, the Valhallfonna Formation is divided into two members (Fig. 2) in ascending order: the Olenidsletta Member contains predominantly dark-shales and intermittent, partly bioturbated, 
grey limestone intervals, and the Profilbekken Member contains grey lime-mudstone and locally distinct silty-glauconitic beds and horizons dominated by intraclastic-skeletal grainstone and packstone lithologies (Kröger et al. 2017). The Olenidsletta Member has a thickness of ca 145-160 m (Fortey \& Bruton 1973; Kröger et al. 2017) and the Profilbekken Member comprises ca 110-160 m (Fortey \& Bruton 1973; Kröger et al. 2017).

The Olenidsletta Member has been divided into six trilobite assemblage zones (Fortey 1980) which can be relatively well correlated with Laurentian shelly faunal zones (Hintze 1953; see also, e.g., Brett \& Westrop 1996; Fortey \& Droser 1999 for discussion). Additionally, the rich graptolite succession of the Olenidsletta Member facilitates a detailed correlation with time equivalent strata elsewhere and a relatively precise biostratigraphic zonation (Cooper \& Fortey 1982). Conodonts help further constrain the biostratigraphy of the Olenidsletta Member (Lehnert et al. 2013). Altogether, these biostratigraphical studies facilitate correlation of the Olenidsletta Member at an exceptionally high resolution (Fig. 2).

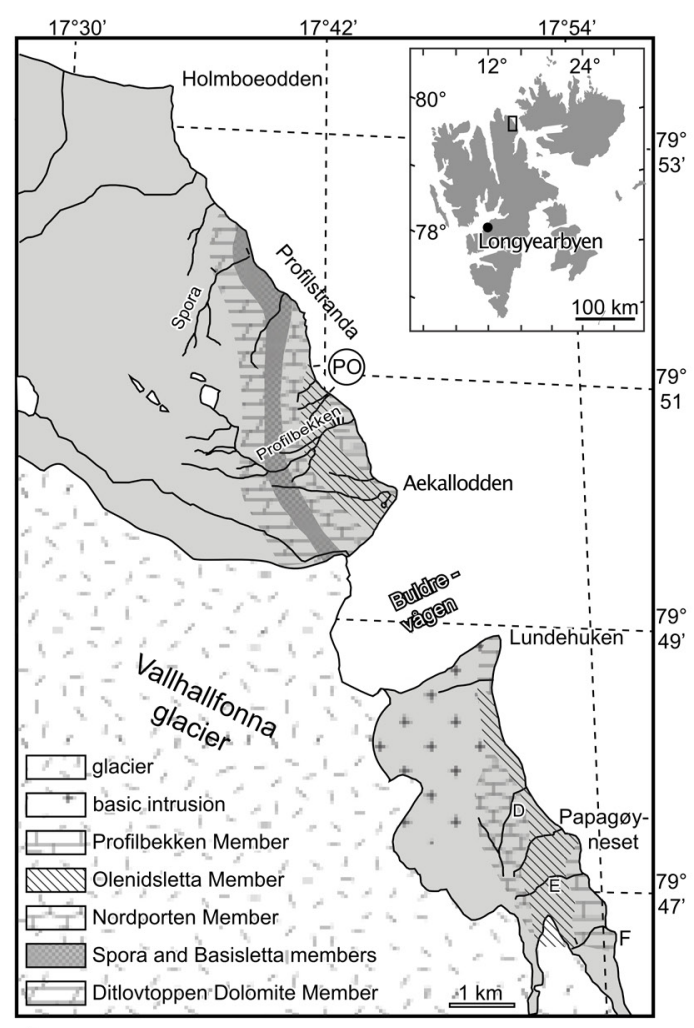

A
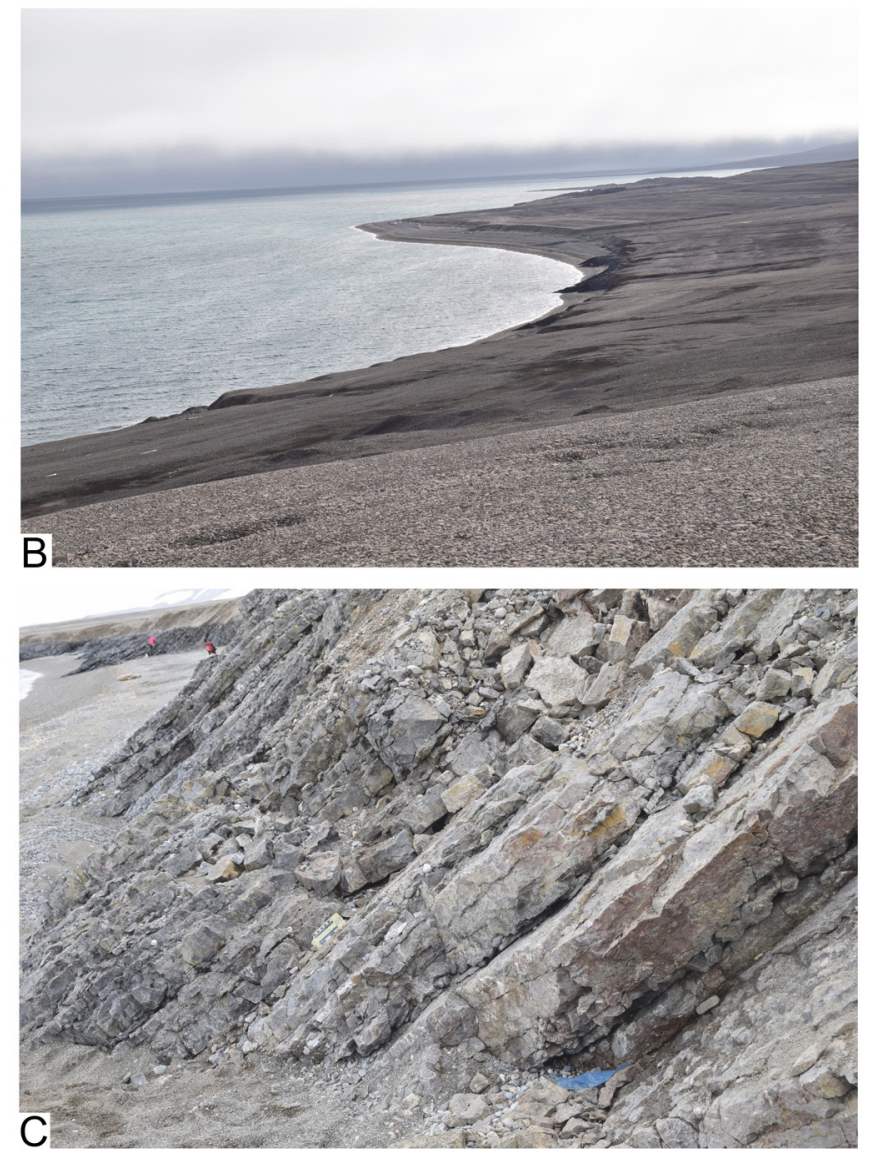

Fig. 1. The Profilstranda-Olenidsletta Member (PO) section adjacent to Hinlopenstretet, Ny Friesland, Spitsbergen. A. Map of the outcrop area adjacent to Hinlopenstretet (Basissletta area in the north and the Olenidsletta in the south; inset is Svalbard, with Spitsbergen as its largest island). The river names $\mathrm{D}$, and $\mathrm{E}$, and the promontory name $\mathrm{F}$ are the same as in Fortey \& Bruton (1973: fig. 1) (modified from Kröger et al. 2017). B. Aspect of the PO section from north-northeast. C. Outcrop situation 07/2016, view from bed PO 3 toward the south with middle and upper part of the Olenidsletta Member in the background. 


\section{Material}

Several expeditions have visited the coastal exposures of the Vallhallfonna Formation adjacent to the Hinlopen Strait (Hinlopenstretet) at the northeastern edge of Ny Friesland, Spitsbergen, and collected samples (see Fortey \& Bruton 1973 and Kröger et al. 2017, for review). A substantial number of cephalopods was collected by D.L. Bruton and R.A. Fortey during their 1971 expedition to the Hinlopenstretet. The material was sent to R.H. Flower (1913-1988), never published, and is currently untraceable in his inheritance, probably now at the U.S. National Museum of Natural History / Smithsonian Institution (Washington, DC, USA) (Wolberg 1991). Only a small part of the originals with limited stratigraphic information has been returned to the collections of the Natural History Museum at the University of Oslo (PMO, Oslo, Norway) (D.L. Bruton pers. com.).

The cephalopods described herein come from the 2016 expedition to the Hinlopenstretet, headed by Melanie J. Hopkins (American Museum of Natural History, New York, USA), and filed under Research in Svalbard (RiS) ID number 10467. The cephalopods were collected by the main author. The material available at PMO was not considered herein, because of limited accessibility during the Covid-19 situation in 2020/2021 and because of the limited stratigraphic resolution of the Oslo material (D.L. Bruton and H.A. Nakrem, Oslo, pers. com.).

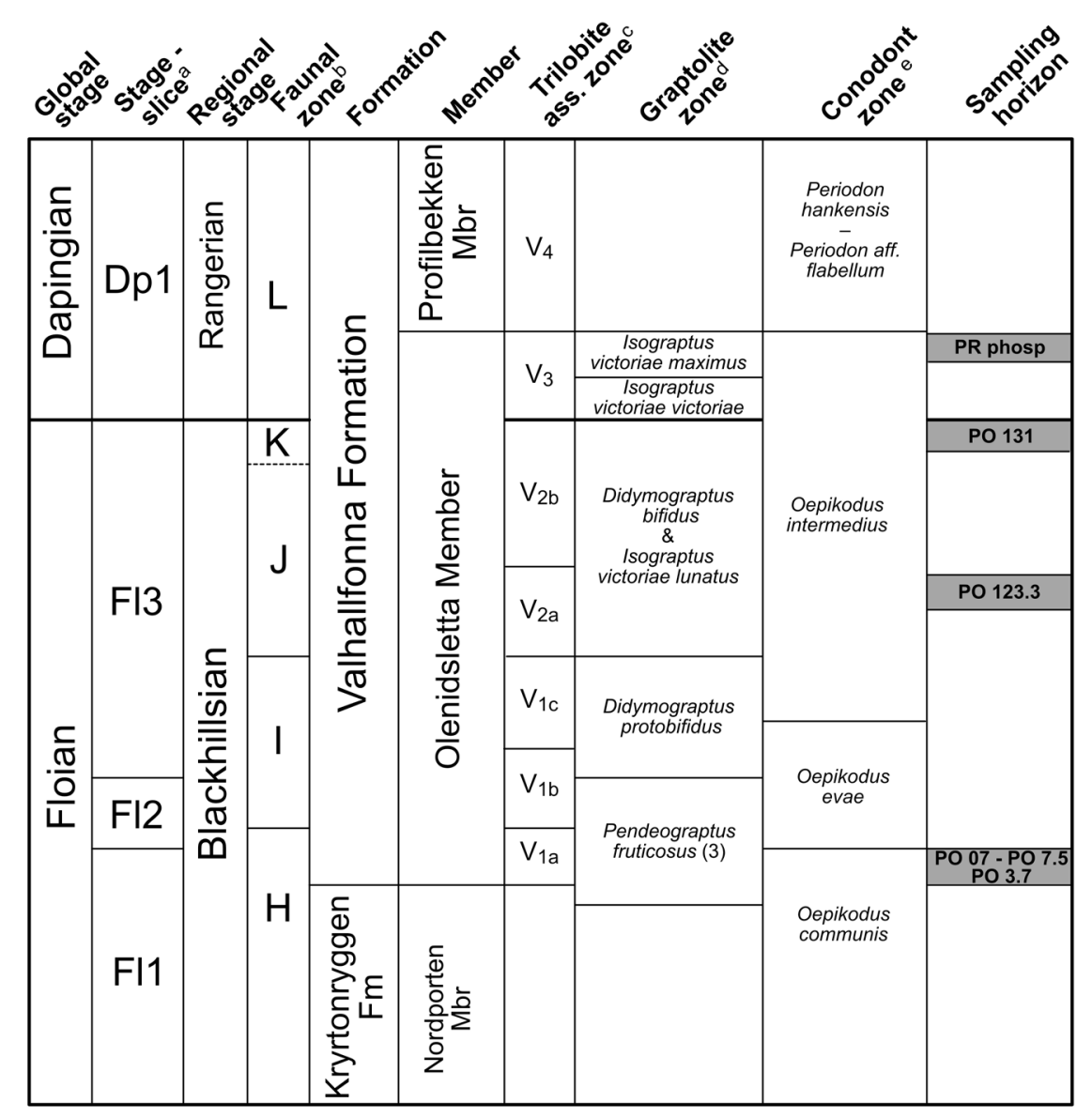

Fig. 2. Stratigraphy of the Olenidsletta Member. ${ }^{a}$ Chronostratigraphic stage slices after Bergström et al. (2009) and Rasmussen et al. (2019), 'b faunal zones western USA after Hintze (1953), ctrilobite assemblage (ass.) zones after Fortey (1980), ${ }^{\mathrm{d}}$ graptolite zones after Cooper \& Fortey (1982), ${ }^{\mathrm{e}}$ conodont zones after Lehnert et al. (2013). Abbreviation: PR phosp = PR-phosphatic (see text). 
The largest part of the material presented and analyzed herein was collected along the outcrop at Profilstranda (section PO of Kröger et al. 2017: fig. 1). The base of the Olenidsletta Member is exposed near $79^{\circ} 51^{\prime} 02.9^{\prime \prime} \mathrm{N}, 017^{\circ} 41^{\prime} 24.0^{\prime \prime} \mathrm{E}$ and the outcrop ends at a mouth of a small melt stream at $79^{\circ} 50^{\prime} 49^{\prime \prime} \mathrm{N}, 017^{\circ} 42^{\prime} 04^{\prime \prime} \mathrm{E}$ within the uppermost few meters of the member.

The cephalopods recovered from the sampling horizons were mechanically prepared and partially cleaned from covering sediment, where necessary. Selected specimens with well-preserved phragmocones were cut and polished. All cephalopod specimens collected at Profilstranda during the 2016 expedition are in the repository of the Finnish Museum of Natural History (FMNH). The complete list of specimens and measurements is available as supplementary file at https://doi.org/10.5281/zenodo.5744814.

\section{Methods}

All measurements were taken using vernier calipers or a calibrated graticule inserted into one eyepiece of a binocular microscope and are available in Supp. file 1 and Supp. file 2. Unless otherwise indicated, the specimens were coated with ammonium chloride and then photographed. Polished median sections of selected specimens were prepared and photographed.

The established naming of nautiloid orders with short endings "cerida" (Teichert et al. 1964; Teichert 1969) is used herein. This practice is used instead of the longer "ceratida", suggested by King \& Evans (2019), in order to avoid confusion in naming and also because of the practicalities in using plurals, because it allows easy distinction between order and family level; e.g., 'riocerids' denominate member of the order Riocerida King \& Evans, 2019 and 'rioceratids' denominate members of the family Rioceratidae Kröger \& Evans, 2011.

\section{Descriptive indices}

The relative chamber length ( $\mathrm{rCL}$ ), the relative siphuncular diameter (rSD), and the relative conch width $(\mathrm{rW})$ are ratios of the corresponding conch height, respectively. The siphuncular position ratio (rSP) is adapted from Frey (1995), and calculated as the minimum distance of the septal foramen from the conch margin divided by the corresponding conch height. It differs from Frey's (1995) rSP in that herein the distance is measured between the conch margin and the nearest part of the septal foramen and not (as in Frey 1995) between the conch margin and the center of the siphuncle. The septal foramen is often poorly preserved, which results in imprecise measurements, and as a consequence a relatively wide scatter of rSD and rSP. The whorl expansion rate (WER) adopted from Korn \& Klug (2003) is used for the description of coiled specimens. The whorl expansion rate is calculated as WER $=(\mathrm{dml} / \mathrm{dms})^{2}$ where $\mathrm{dml}$ is the diameter of the conch and dms the diameter of the $360^{\circ}$ preceding dml. The whorl width index (WWI) is the whorl width divided by the whorl height and corresponds to $\mathrm{rW}$ in non-coiled specimens. Additionally, the relative depth of the impression zone IZR is given as the ratio of the height of the impression zone/whorl height, and the LER describes the expansion of the conch width calculated as LER $=(\mathrm{wml} / \mathrm{wms})^{2}$ where wml is the conch width and wms the conch width $360^{\circ}$ around the preceding wml.

The descriptive terms cyrtochoanitic and suborthochoanitic are often used interchangeably; here, 'loxochoanitic' is used when the angle of the septal neck is less than 90 degrees; 'orthochoanitic' is used when it is nearly 90 degrees; 'suborthochoanitic' is used when it is $90-180$ degrees; and 'cyrtochoanitic' when it is more than 180 degrees. This strict usage in some cases causes deviations from original species or genus diagnoses, which are not evaluated as diagnosis emendations, because they regard the terminology only and not the diagnostic characters themselves.

\section{Ecological proxies and diversity indices}

The implosion depth of orthoconic cephalopod phragmocones was calculated using the implosion depth formula of Hewitt \& Westermann (1996: equation 4) which is based on the septal strength index (SSI) of Westermann (1973). 
The diversity $\left(\mathrm{D}_{\mathrm{H} 0}\right)$ is given as effective number of species or Hill number of order $\mathrm{q}=0$ (see Chao et al. 2016) and was calculated as an extrapolation from the abundance matrix using the function iNEXT() in the R-package "iNEXT" ver. 2.0.19 (Hsieh et al. 2016). The evenness (J) is given as Pielou's evenness index (Pielou 1966), calculated as $\mathrm{H}^{\prime} / \mathrm{H}^{\prime}{ }_{\text {max }}$, where $\mathrm{H}^{\prime}$ is the Shannon diversity index and $\mathrm{H}_{\max }$ is the natural logarithm of the number of species (S) in the sample. Here, $\mathrm{H}^{\prime}$ and $\mathrm{S}$ was calculated as extrapolations from the abundance matrix using the functions ChaoShannon() and ChaoSpecies() in the R-package "iNEXT". Microscopic specimens (apex fragments) were excluded from the diversity analyses because they result from a different sampling practice where selected rock samples were split in small pieces and searched for cephalopods under the microscope.

\section{Cladistic analyses}

A selection of slightly modified characters and taxa from Pohle et al. (submitted) is used herein, combined with several taxa described here (Supp. file 3). The characters were selected to represent only parsimony informative characters with less than $50 \%$ missing data for the selected taxa. The character matrix was analyzed in TNT ver. 1.5 (Goloboff \& Catalano 2016), employing the traditional search algorithm using tree-bisectioning-reconnecting (TBR) branch swapping with 1000 random addition sequences, each holding up to ten trees. Bremer support was calculated for the most parsimonious trees (Bremer 1988, 1994) and absolute and relative (GC) bootstrap frequencies were obtained from 1000 pseudoreplicates (Felsenstein 1985; Goloboff et al. 2003). We conducted four separate analyses to test different scenarios. Because it is sometimes challenging to differentiate between tubular and concave siphuncular segments, two different character matrices were used for each interpretation. For the tubular interpretation, the character "siphuncular segment shape" was treated as continuous, representing the proportion between the heights of the septal foramen and the middle of the siphuncular segment. In cases where the difference was minimal and largely dependent on the exact position of the measurements, we used a value of 1.0, i.e., the shape of the siphuncle was assumed to be tubular. For the concave interpretation, the same character was treated as discrete unordered, with three states: concave, tubular and slightly expanded. Accordingly, all taxa where the shape was treated as tubular in the previous analysis were here considered to be tubular. This approach concerned the following species: Ethanoceras solitudines gen. et sp. nov., Olenidslettoceras farmi gen. et sp. nov., Svalbardoceras sterna gen. et sp. nov., and Valhalloceras floweri Evans \& King, 1990. However, note that these were not the only taxa affected by this change, because the tubular interpretation allows for a more nuanced distinction between segment shapes because of the treatment as a continuous character. In contrast, the concave interpretation puts more emphasis on the change between concave, tubular and expanded siphuncles. This resulted in a character matrix with in total 47 taxa and 45 characters, out of which 11 were continuous, three ordered and the rest unordered. For the concave interpretation, one character was modified from continuous to unordered. For both character sets, an additional tree search was conducted where several topological constraints were enforced at the same time:

1. The monophyly of the Endocerida Teichert, 1933 including Anthoceras vaginatum (Schlotheim, 1820), Cameroceras turrisoides Kröger, 2013, Clitendoceras saylesi Ulrich \& Foerste, 1936, Dideroceras incognitum (Schröder, 1882), Proterocameroceras brainerdi (Whitfield, 1886), Proterovaginoceras belemnitiforme (Holm, 1885), and Thylacoceras kimberleyense Teichert \& Glenister, 1952. Several additional species, namely Hemichoanella canningi Teichert \& Glenister, 1954, H. occulta sp. nov., Lebetoceras oepiki Teichert \& Glenister, 1954, Loxochoanella warburtoni Teichert \& Glenister, 1954, and Ventroloboceras furcillatum Teichert \& Glenister, 1954 were defined as floaters, meaning that they were allowed to fall within the endocerid clade depending on the most parsimonious solution. For this latter set of taxa, an endocerid affinity is somewhat uncertain, because they lack evidence for the diagnostic endocones. Note that $P$. belemnitiforme and possibly also $C$. turrisoides judging by its embryonic conch may belong to the Bisonocerida Evans \& King, 2012, which are here considered as possible sister group to the Endocerida but unlikely to be independent 
descendants of the Ellesmerocerida Flower, 1950 as suggested by Evans \& King (2012). Resolving relationships within the Endocerida/Bisonocerida (see Evans \& King 2012) is out of the scope of this study and the two species are mainly included here to represent a broad spectrum of variation within this clade.

2. The monophyly of the Oncocerida Flower, 1950 including Leonardoceras parvum Flower, 1968, Neumatoceras borense Kröger, Zhang \& Isakar, 2009, Nyfrieslandoceras bassleroceroides gen. et sp. nov., Olenidslettoceras farmi gen. et sp. nov., Richardsonoceras ellipticum (Lossen, 1860), and Valhalloceras floweri Evans \& King, 1990. Phthanoncoceras oelandense Evans \& King, 1990 was considered to belong outside the oncocerid clade (see Kröger et al. 2009b) and thus not included in this constraint.

3. The monophyly of the Orthocerida Kuhn, 1949 including Archigeisonoceras repplingense Kröger, 2004, Nilssonoceras latisiphonatum Kröger, 2004, and Orthoceras regulare Schlotheim, 1820.

\section{Distribution and mode of occurrence}

Cephalopods are abundant at Profilstranda in several beds in the lower part of the Olenidsletta Member at ca 3-5 $\mathrm{m}$ above the base of the formation, in the middle part of the member at ca 119-128 $\mathrm{m}$ above the base of the formation, and in the upper part of the member at 136-141 $\mathrm{m}$ above the base of the formation (Kröger et al. 2017). Because of time constraints during the 2016 expedition, only seven beds within, and only the lower and middle parts of the member were sampled for cephalopods (Fig. 3).

Sampling concentrated on horizons where cephalopods are most abundant, well preserved and easy extractable. The sampling time and effort was approximately similar for PO 7.5, PO 123.3, and PO 131, which are the main sampling horizons. The details of preservation and taphonomy differ among the sampling horizons and can be summarized as follows:

The cephalopods of the sample horizons PO 3.7-PO 04 are from a ca $1 \mathrm{~m}$ thick, massive, burrow homogenized, partly stylolithic, partly dolomitic light grey lime mudstone to skeletal wackestone bed. Cephalopods are less common in PO 3.7-PO 04 than in the other sampled horizons and are often poorly preserved because of local dolomitization and generally massive recrystallization.

The sample horizons PO 07 and PO 7.5 are in a ca $3 \mathrm{~m}$ thick part of the section which consists of upward thickening light gray burrow-homogenized 5 to $30 \mathrm{~cm}$ thick lime mudstone to skeletal wackestone beds, and upward thinning shales. The cephalopods appear to be concentrated in the limestone beds and in part occur in coquina-like concentrations (Fig. 4C-D). The overwhelmingly short (few decimeters in original length) orthoconic conchs are current aligned and often broken and partially gravitationally filled. Telescoping of the conchs is common. The gravitational fillings indicate that no heavy reworking occurred after sparite crystallization within the conchs. However, many conchs show syndepositional erosion or dissolution of the upper, probably exposed, conch surfaces with parts of the shell not preserved.

In many specimens the conch structure and that of the septa and siphuncle are poorly or not at all preserved. The poor preservation is mainly caused by heavy recrystallisation of the original shell. Additionally, septa are often imploded and buckled. This is the case with cephalopods across the taxonomic spectrum. A fine pyrite impregnation of the shells is common.

In terms of sedimentological aspects, the general appearance of the cephalopod concentrations of sample horizons PO 07 and PO 7.5 is comparable to the Braník-type cephalopod limestones of the Silurian of the Prague Basin (see, e.g., Ferreti \& Kř́ž 1995), but lacks bivalves and other benthic faunal elements, as well as epizoans on conch surfaces. Trilobites occur as secondary faunal elements in sample horizons PO 07 and PO 7.5. 
Sample horizon PO 123.3 is positioned in the middle of a ca $2 \mathrm{~m}$ thick parasequence, consisting of intercalations of upwardly thickening light gray to greenish-gray burrow-homogenized 5 to $20 \mathrm{~cm}$ thick nodular to wavy bedded lime mudstone to skeletal wackestone beds and with upwardly thinning dark shale inter-layers. The top of the parasequence at ca $121.2 \mathrm{~m}$ above the base of the Olenidsletta Member is formed by a $<0.2 \mathrm{~m}$ thick succession of at least two hardgrounds with a distinctive, knobbly, irregular surface that cut into a cephalopod and trilobite rich skeletal rudstone layer. The sedimentological features of sample horizon PO 123.3 are in general very similar to that of PO 7.5, except that the cephalopods are less densely packed, and that trilobites and gastropods are more common.

Sample horizon PO 131 is the topmost bed of a ca $0.8 \mathrm{~m}$ thick parasequence of a thickening up of layers of greenish-gray limestone and thinning up dark shale inter-layers. Flint nodules with a thickness of ca $3 \mathrm{~cm}$ are common in the middle part of the parasequence. Bed PO 131 is less than two decimeters thick and consists of a rudstone, rich in skeletons of cephalopods, gastropods and trilobites, which covers a distinctive, knobbly, irregular hardground (Fig. 4A). The fragments of cephalopods and cuticles of trilobites are not current-oriented or sorted; and telescoping of the cephalopod shells is less common when compared with sample horizons PO 7.5 and PO 123.3. The cephalopod shells are comparatively well preserved, and details of the septal neck and connecting ring are visible in polished sections. The matrix of the rudstone consists partly of concentrations of ca 1-3 mm large, dark grey, lens-shaped limestone ooids, is locally rich in minute (mm-size) gastropods, and it can be interpreted as a shell-

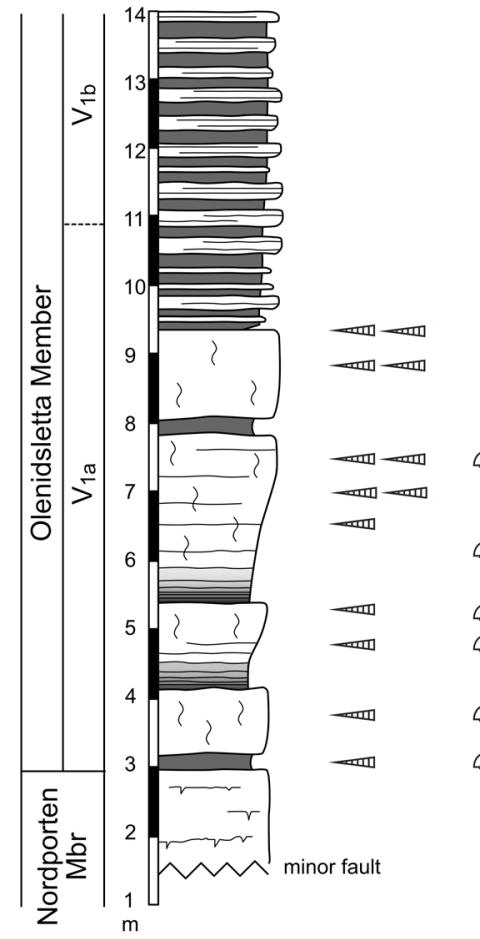

A

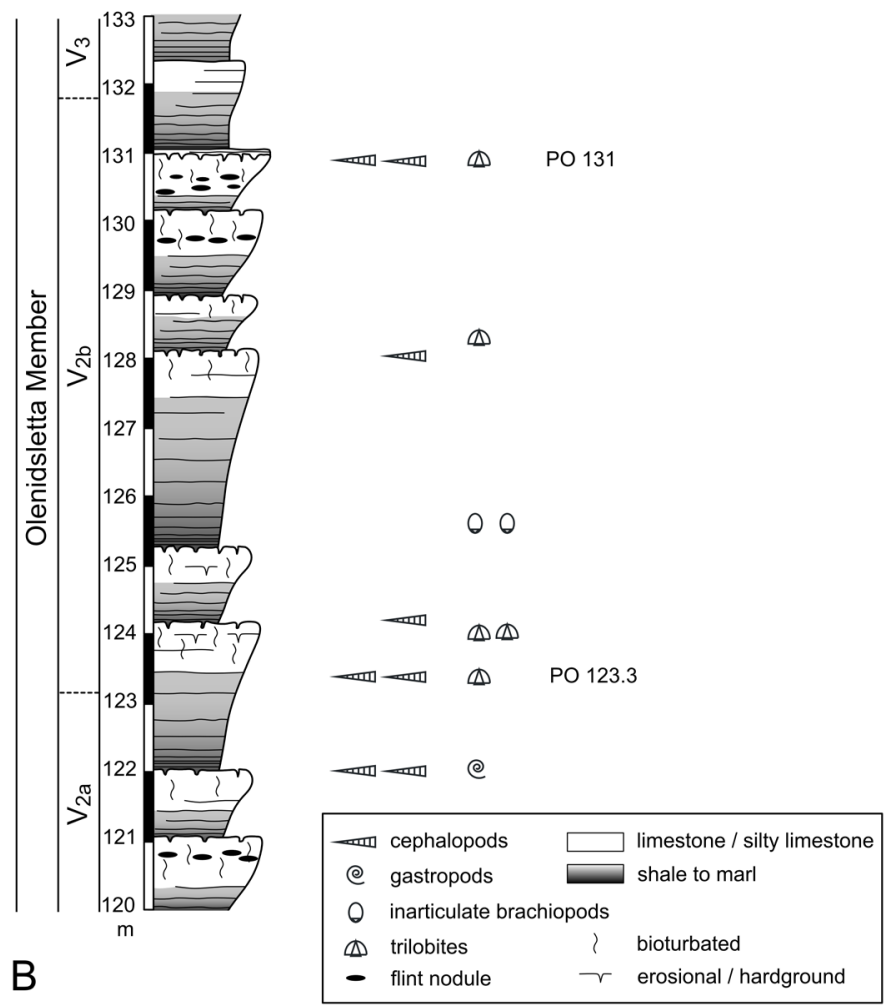

Fig. 3. Details of the lithological succession of the Olenidsletta Member, Floian, Ordovician, Profilstranda section, Ny Friesland, Spitsbergen (for complete section see Fig. 53 and Kröger et al. 2017: fig. 9). A. Lower part of the Olenidsletta Member with sample horizons PO3.7-7.5. B. Middle part of the Olenidsletta Member with sample horizons PO 123-123.5, PO 131. Mbr. = Member, Trilobite biozones after Kröger et al. (2017). Fossil symbols denote abundant ( $1 \times$ per bed) or very abundant $(2 \times$ per bed) occurrences. 
lag deposit on top of a hardground. A fine pyrite impregnation of the shells and the ooids is common. Horizon PO 131 represents the uppermost bed below a marked facies change giving rise to a succession of several ca 1-2 m thick paracycles, each dominated by a dark, laminar shale and topped with a burrowhomogenized, dark grey lime mudstone with a flat hardground or omission surface. The top centimeters of the lime-mudstone are rich in small $(<10 \mathrm{~mm}$ in diameter) orthoconic cephalopods.

The uppermost meters of the Olenidsletta Member are not exposed at Profilstranda, but along the Profilbekken River south of Profilstranda. The river cuts through the Valhallfonna Formation at a very low angle and the beds are repeated by a number of folds and faults, making a reliable thickness measurement very difficult, especially within the Olenidsletta Member / Profilbekken Member boundary interval. An exposure, rich in minute orthoconic cephalopods, is present ca $860 \mathrm{~m}$ south of the upper end of the Profilstranda outcrop $\left(79^{\circ} 50^{\prime} 24.75^{\prime \prime} \mathrm{N}, 017^{\circ} 41^{\prime} 25.83^{\prime \prime} \mathrm{E}\right)$. This site has been named "PRphosphatic" and exposes a series of meter-thick paracycles of dark shales and dark grey lime mudstone, the latter with tending to thickening up sequences. They are topped by a partly erosional hardground. In some places the surface of the hardground has a pinkish color and is interpreted as being phosphate-rich. The uppermost limestone layers of some paracycles contain masses of small, well preserved orthoconic cephalopods (Kröger 2017 et al.: fig. 10c). The lithology at "PR-phosphatic" indicates a stratigraphic position within the uppermost part of the Olenidsletta Member, and within the Dapingian V3 trilobite assemblage zone, Isograptus victoriae maximus graptolite zone (Fortey 1980; Cooper \& Fortey 1982; Kröger et al. 2017).
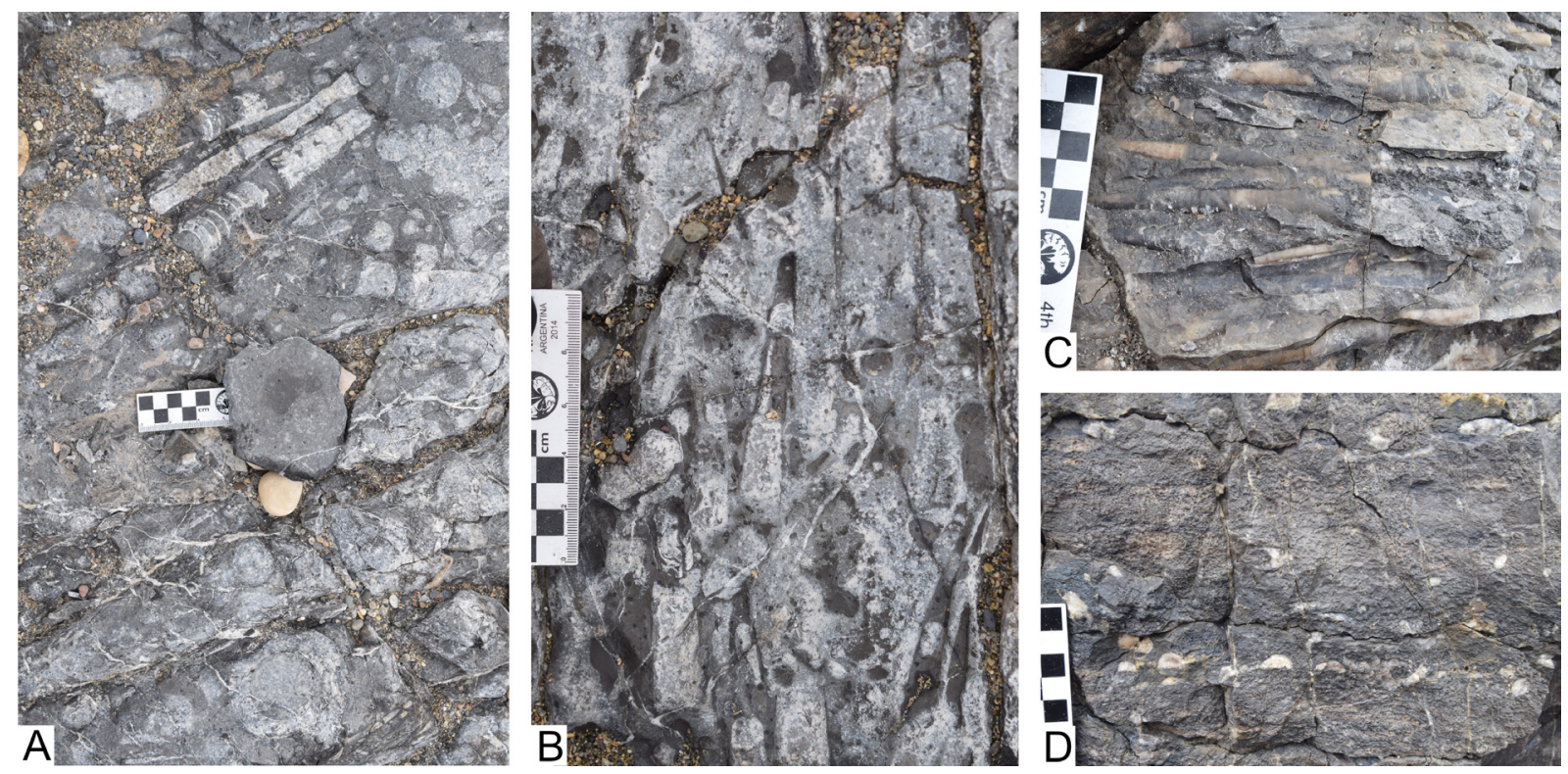

Fig. 4. Field photographs of sample horizons of the Olenidsletta Member, Floian, Ordovician, Profilstranda section, Ny Friesland, Spitsbergen. A. Bed PO 131, $128 \mathrm{~m}$ above the base of the member, view of a bedding surface with several chaotically distributed fragments of orthoconic and coiled cephalopods. Note also the round shapes of individual septa from fragmented orthoconic shells. B. Bed PO 122, $119 \mathrm{~m}$ above the base of the member, view of a top hardground bedding surface of a limestone paracycle; the cephalopod assemblage is strongly dominated by current aligned, abundantly telescoped orthocones, and conchs are poorly preserved as steinkerns. C. Bed PO 7.5, 4.5 m above the base of the member, oblique freshly broken surface of a cephalopod coquina with current aligned, abundantly telescoped orthocones. D. Same bed in vertical view, cutting the current aligned orthocones in perpendicular direction; note the gravitational fillings, which are in original position with sparite fillings on top. 


\section{Results}

Phylum Mollusca Linnaeus, 1758

Class Cephalopoda Cuvier, 1797

Order Ellesmerocerida Flower in Flower \& Kummel, 1950

Family Bassleroceratidae Ulrich, Foerste, Miller \& Unklesbay, 1944

Genus Lawrenceoceras Ulrich, Foerste, Miller \& Unklesbay, 1944

\section{Type species}

Lawrenceoceras collinsi Ulrich, Foerste, Miller \& Unklesbay, 1944 from boulders at Point Levis, Levis County, Quebec, Canada (presumably late Floian); by original designation.

\section{Diagnosis}

Smooth, slender, cyrtocones with elliptically depressed cross section. Sutures directly transverse, with very shallow, broad dorsal and ventral lobes. Siphuncle small, about 0.1 of conch diameter, on convex side of conch, almost marginal in position. Siphuncular segments cylindrical or nearly so (compiled from Ulrich et al. 1944).

Lawrenceoceras ebenus sp. nov

urn:1sid:zoobank.org:act:C148361C-5535-4AE5-8835-282F9C8C3EC3

Figs 5D-E, 6A, 7B, 8A

\section{Diagnosis}

Exogastrically curved conch with angle of expansion of conch width of ca $8^{\circ}$ and slightly depressed conch cross section $(\mathrm{rW}=1.12)$; ornamented with fine directly transverse striae and rugae. Siphuncle small, 0.1 of conch height and near conch margin.

\section{Etymology}

In honour to the Svalbard Husky "Ebony”, from the Latin 'hebenus', 'ebony'.

\section{Type material}

\section{Holotype}

Specimen FMNH-P30335; by monotypy.

\section{Type locality and horizon}

Profilstranda section, adjacent to Hinlopenstretet, Spitsbergen, bed Po123.3, $120.3 \mathrm{~m}$ above base of Olenidsletta Member, V2a trilobite zone, Blackhillsian, Floian.

\section{Description}

Specimen FMNH-P30335 is a fragment of a curved phragmocone and part of a body chamber with a length of $31 \mathrm{~mm}$ and a conch width of $9-13.3 \mathrm{~mm}$ (angle of expansion ca $8^{\circ}$ ). The preserved part of the body chamber is $8 \mathrm{~mm}$ long.

The conch surface is ornamented with fine directly transverse striae, 10-12 striae occur per $\mathrm{mm}$ at a conch height of ca $11 \mathrm{~mm}$. The adoral ca $10 \mathrm{~mm}$ of the fragment surface is additionally ornamented with irregularly spaced rugae. Striae form a very shallow hyponomic sinus on the convex side of the conch curvature. 

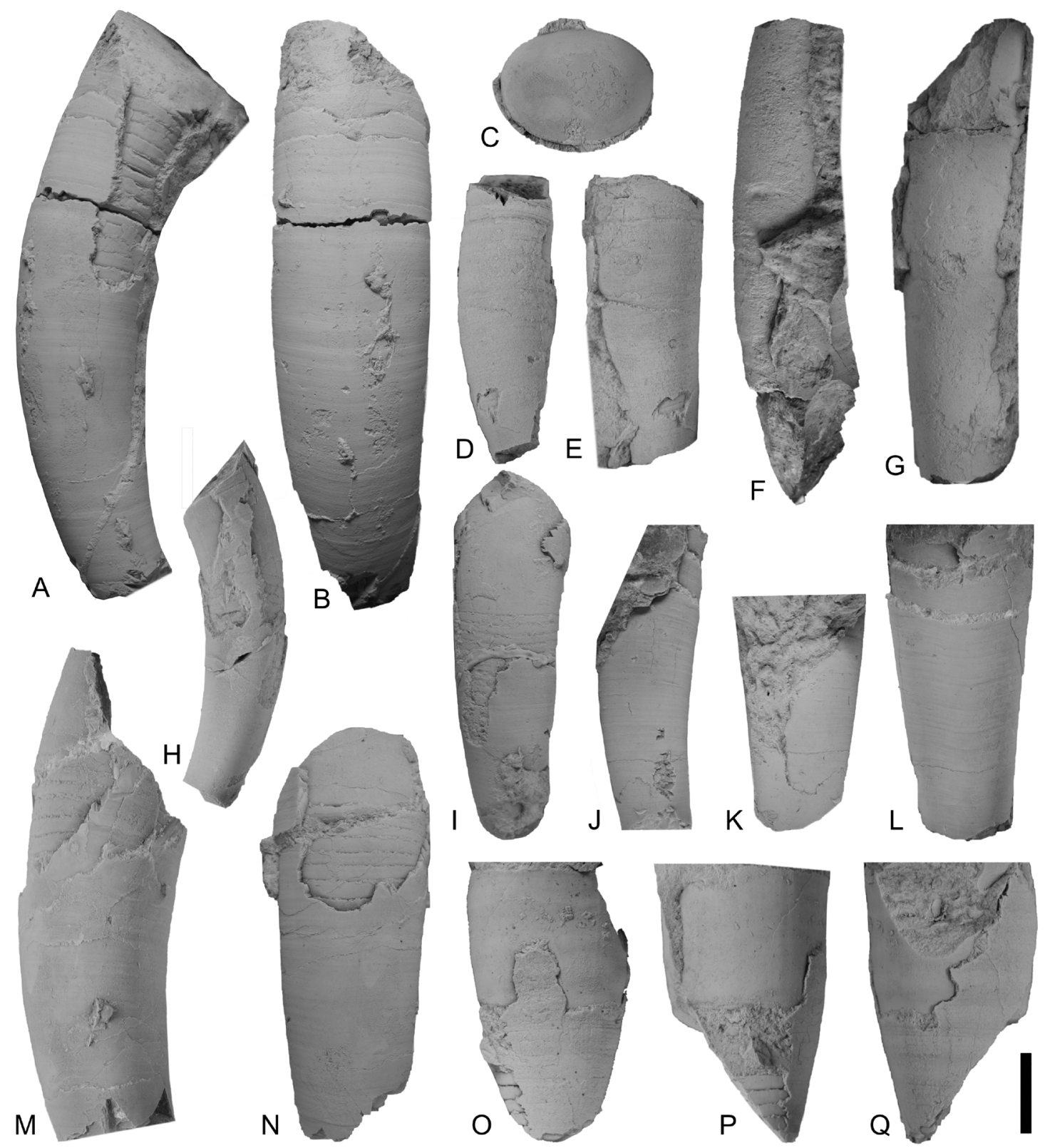

Fig. 5. Cyrtoconic cephalopods from the Olenidsletta Member, Floian, Ordovician, Profilstranda section, Ny Friesland, Spitsbergen. A-C. Lawrenceoceras larus sp. nov., FMNH-P30351, holotype, from bed PO 131. A. Lateral view with siphuncle on left side. B. Ventral view, prosiphuncular side. C. Adoral view of septum and septal perforation. D-E. Lawrenceoceras ebenus sp. nov., FMNH-P30335, holotype, from bed PO 123.3. D. Lateral view with siphuncle on left side. E. Ventral view, prosiphuncular side. F-G. Olenidslettoceras farmi gen. et sp. nov., FMNH-P30334, holotype, from bed PO 123.3. F. Lateral view with siphuncle on left side. G. Ventral view, prosiphuncular side. H-N. Vallhalloceras floweri King \& Evans, 1990. H-I. Specimen FMNH-P30337, from bed PO 131. H. Lateral view, siphuncle on right side I. Ventral view, prosiphuncular side. J-L. Specimen FMNH-P30343 from bed PO 123.3, J. Lateral view with siphuncle on left side. K. Ventral view, prosiphuncular side. L. Dorsal view, antisiphuncular side. M-N. Specimen FMNH-P30338 from bed PO 131. M. Lateral view with siphuncle on left side. N. Ventral view, prosiphuncular side. $\mathbf{O}-\mathbf{Q}$. Cyclostomiceras profilstrandense sp. nov., specimen FMNH-P30336, from bed PO 123.3. O. Lateral view with siphuncle on left side. P. Ventral view, prosiphuncular side. $\mathbf{Q}$. Dorsal view, antisiphuncular side. Scale bar $=10 \mathrm{~mm}$ for all figures. 
The conch cross section is slightly depressed, with a height of $11.1 \mathrm{~mm}$ where the width is $12.5 \mathrm{~mm}(\mathrm{rW}=$ 1.12). The septa are narrowly spaced, ca 10-12 chambers occur per distance similar to corresponding conch.

At the adapical end of the specimen the septal perforation is positioned ca $0.7 \mathrm{~mm}$ from the conch margin positioned on the convex side of the conch curvature and has a diameter of $0.7 \mathrm{~mm}$. The connecting ring is thick and with concave segments. The septal necks are short and loxochoanitic.

\section{Comparison}

Lawrenceoceras ebenus sp. nov. is similar in conch cross section to L. larus sp. nov., but differs from the latter species and other species of this genus in having a distinctively ornamented conch surface.

Lawrenceoceras larus sp. nov

urn:1sid:zoobank.org:act:B0503E12-D63A-4656-BAE7-8C22CFB40D5E

Figs $5 \mathrm{~A}-\mathrm{C}, 6 \mathrm{~B}, 7 \mathrm{~A}$

\section{Diagnosis}

Exogastrically curved conch with angle of expansion of conch width of ca $3^{\circ}$ and slightly depressed conch cross section $(\mathrm{rW}=1.16)$; conch surface smooth with fine irregularly spaced growth lines which
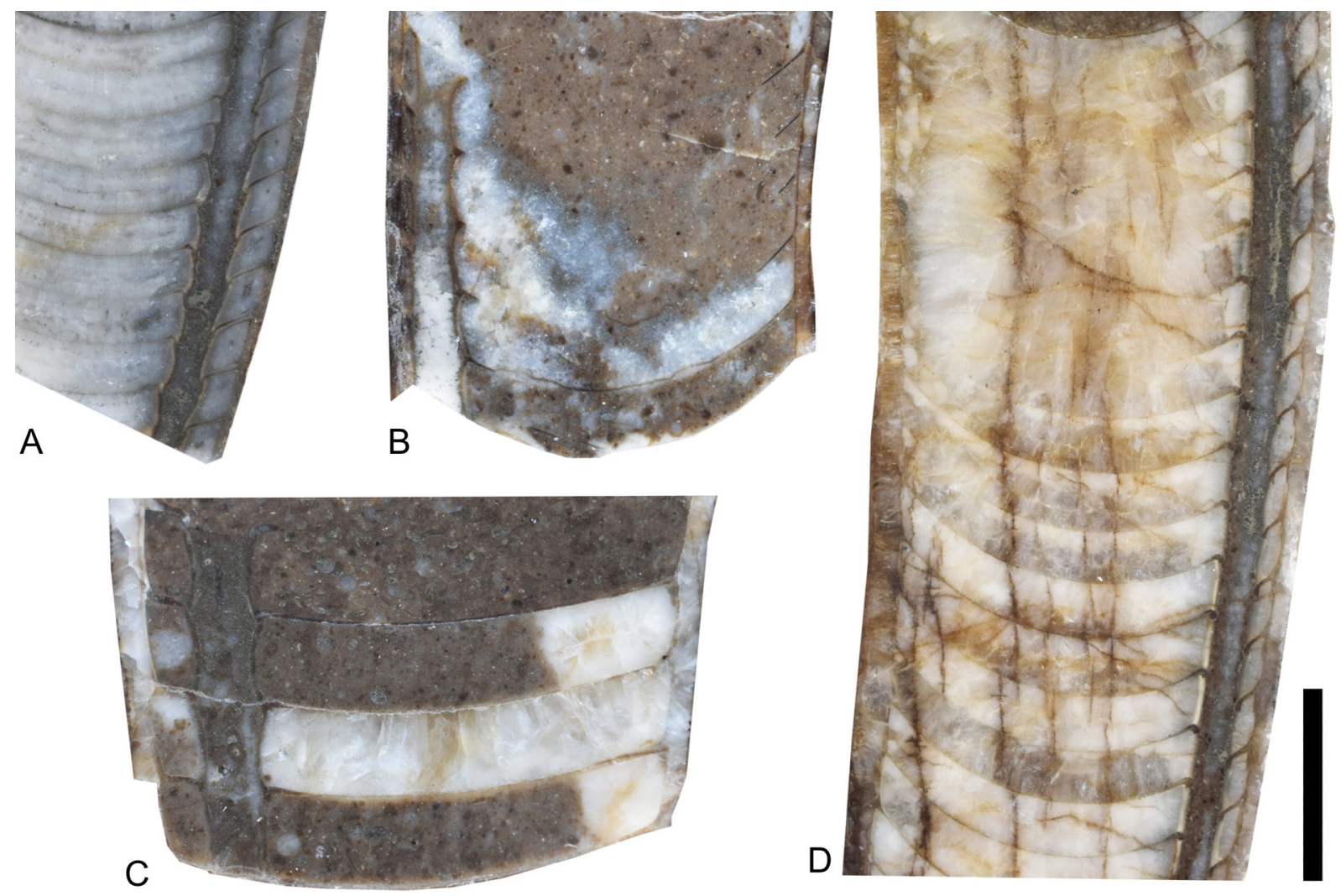

Fig. 6. Median sections of cyrtoconic cephalopods from the Olenidsletta Member, Floian, Ordovician, Profilstranda section, Ny Friesland, Spitsbergen. A. Lawrenceoceras ebenus sp. nov., FMNH-P30335, holotype, from bed PO 123.3. B. Lawrenceoceras larus sp. nov., FMNH-P30355, paratype, from bed PO 131. C. Vallhalloceras floweri Evans \& King, 1990, FMNH-P30340, from bed PO 131. D. Olenidslettoceras farmi gen. et sp. nov., FMNH-P30334, holotype, from bed PO 123.3. Scale bar = $5 \mathrm{~mm}$ for all figures. 
form shallow hyponomic sinus at convex side of conch curvature; siphuncle small, 0.1 of conch height and near conch margin.

\section{Etymology}

From the gull genus Larus Linnaeus, 1758, a common companion during fieldwork at Profilstranda.

\section{Type material}

\section{Holotype}

Specimen FMNH-P30351.

\section{Paratypes}

Five specimens (FMNH-P30337, P30338, P30339, P30342, P30355) from bed PO 131, $128 \mathrm{~m}$ above base of Olenidsletta Member, V2b trilobite zone, Blackhillsian, Floian.

\section{Type locality and horizon}

Profilstranda section, adjacent to Hinlopenstretet, Spitsbergen, bed Po123.3, $120.3 \mathrm{~m}$, above base of Olenidsletta Member, V2a trilobite zone, Blackhillsian, Floian.
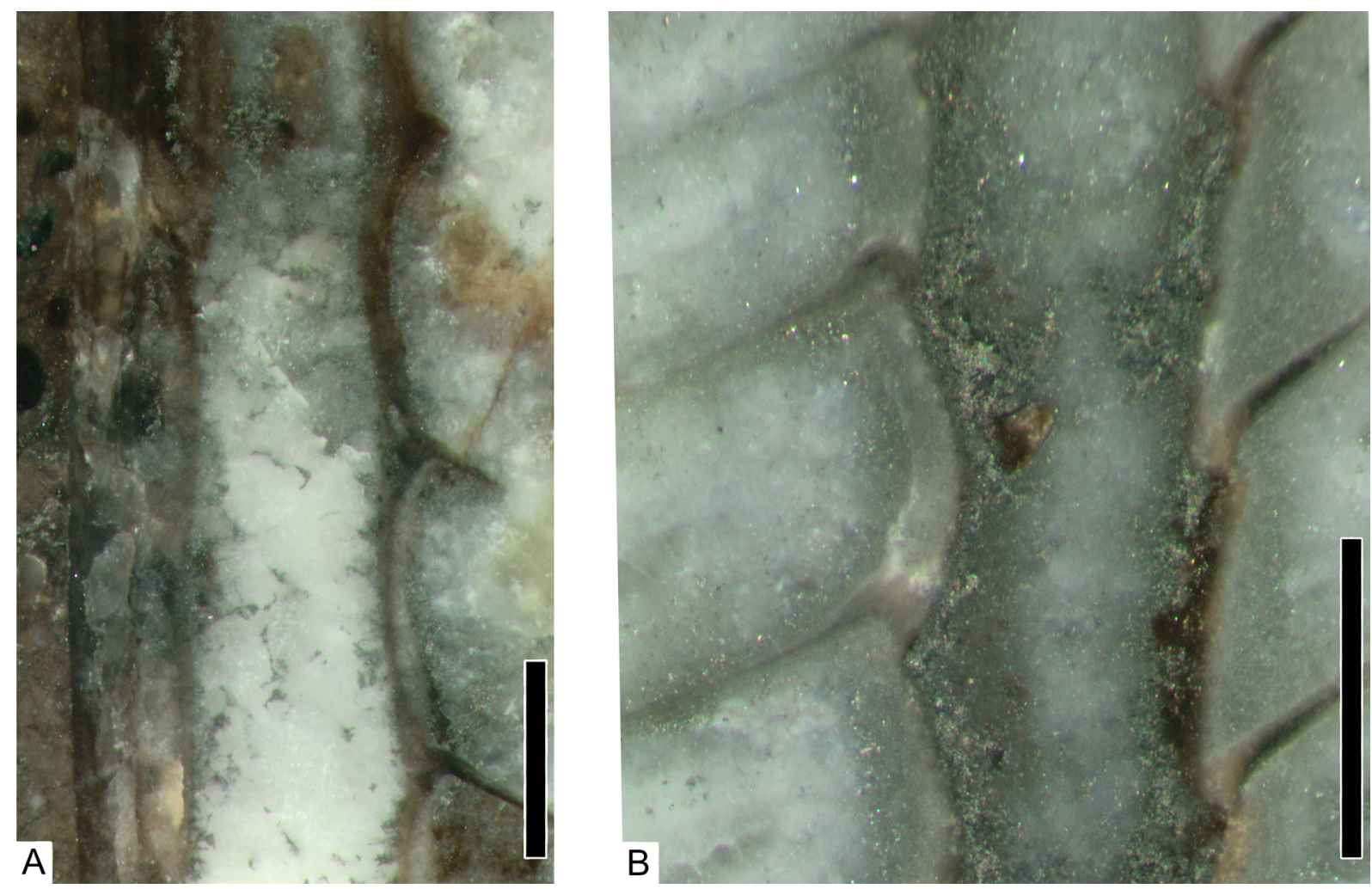

Fig. 7. Details of siphuncle and septal necks, median sections of cyrtoconic ellesmeroceratids from the Olenidsletta Member, Floian, Ordovician, Profilstranda section, Ny Friesland, Spitsbergen. Note the loxochoanitic septal necks and the concave siphuncular segments. A. Lawrenceoceras larus sp. nov., FMNH-P30355, paratype, from bed PO 131. B. Lawrenceoceras ebenus sp. nov., FMNH-P30335, holotype, from bed PO 123.3. Scale bar $=1 \mathrm{~mm}$ for all figures. 


\section{Description}

The holotype is a fragment of a curved phragmocone with a length of $65 \mathrm{~mm}$, its width expands from 13.5 to $16.5 \mathrm{~mm}$ over a length of ca $48 \mathrm{~mm}$ (angle of expansion ca $4^{\circ}$ ). The conch surface is almost smooth, ornamented only with faint irregularly spaced growth lines, which form a very shallow sinus on the convex side of the conch curvature and a broad and shallow, but distinctive hyponomic sinus at the concave side of the conch curvature.

The conch cross section is depressed $(\mathrm{rW}=1.16-1.23)$ with the dorsum slightly flattened compared with the ventral side. Ten measurements of the relative conch width including the additional material result in a mean value of $\mathrm{rW}=1.3\left(1^{\text {st }-3^{\text {rd }}}\right.$ quantile $\left.=1.24-1.33, \mathrm{n}=10\right)$.

The septa are narrowly spaced, ca 10 chambers occur per distance similar to corresponding conch height and the sutures form a shallow lobe at the lateral flanks $(\mathrm{rCL}=0.1)$. The septal curvature is relatively strong, ca $2-3 \mathrm{~mm}$ at the adapical end of the specimen.

The septal perforation is positioned almost at the margin of the conch on the convex side of the conch curvature and has a diameter of $1.5 \mathrm{~mm}$ at a position where the conch height is $13 \mathrm{~mm}$.

In specimen FMNH-P30355 details of the siphuncle and septal necks are preserved. There, the connecting ring is thickened with concave segments and the septal necks are short loxochoanitic. No endosiphuncular and/or cameral deposits are known.

\section{Comparison}

The new species differs from other species of Lawrenceoceras in having a relatively low angle of conch width expansion; it also differs from the type species in having a more depressed conch cross section (rW in L. collinsi is ca 1.06). Lawrenceoceras confertissimum (Whitfield, 1886) from the Fort Cassin Formation, New York, USA has a larger rate of expansion of the conch width $\left(12.5^{\circ}\right.$ compared with $4^{\circ}$ in L. larus sp. nov.). Lawrenceoceras australe (Ulrich et al., 1944) from the Odenville Limestone, Alabama, USA differs in having a more depressed conch $(\mathrm{rW}=1.34)$ with a distinctive triangular conch cross section.

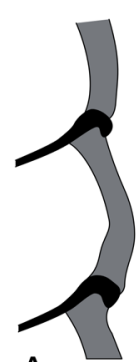

A

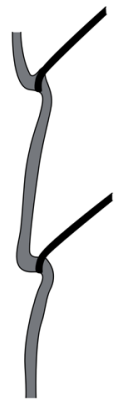

$\mathrm{B}$

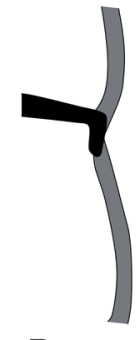

(1)

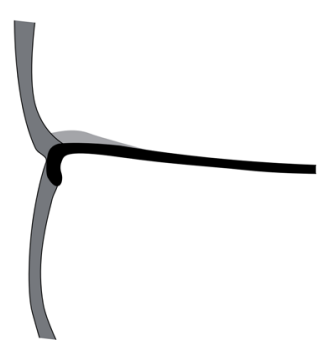

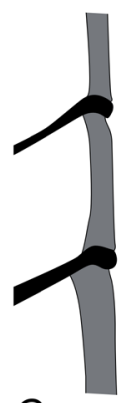

C

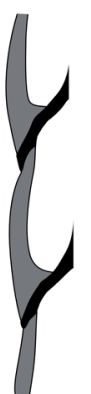

$\mathrm{D}$

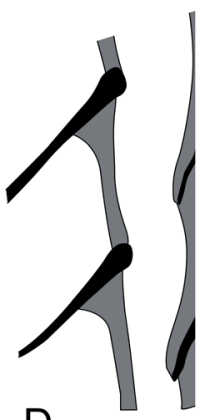

Fig. 8. Reconstruction and interpretation of details of connecting ring and septal necks in cyrtoconic cephalopods from the Olenidsletta Member, Floian, Ordovician, Profilstranda section, Ny Friesland, Spitsbergen. A. Lawrenceoceras ebenus sp. nov., FMNH-P30335, holotype, see also Fig. 7B. B. Vallhalloceras floweri Evans \& King, 1990, FMNH-P30340, see also Fig. 50B. C. Olenidslettoceras farmi gen. et sp. nov., FMNH-P30334, holotype, see also Fig. 50A. D. Nyfrieslandoceras bassleroceroides gen. et sp. nov., FMNH-P30353, holotype, see also Fig. 49C. Black: septal neck and septum. Dark grey: connecting ring. Light grey: cameral deposits. Without scale. 
KRÖGER B. \& POHLE A., Ordovician Spitsbergen cephalopods

Family Cyclostomiceratidae Foerste, 1925

Genus Cyclostomiceras Hyatt, 1900

\section{Type species}

Gomphoceras cassinense Whitfield, 1886 from the Fort Cassin Formation (Floian) at Fort Cassin headland, Vermont, USA; by original designation.

\section{Diagnosis}

Gomphoceroid, breviconic orthocones with circular to depressed conch cross section; phragmocone expanding adorally rapidly; anterior half of mature body chamber slightly contracted. Sutures and growth lines straight and directly transverse; siphuncle small, $\mathrm{rSD}=0.15$, ventral in position but not marginal; septal necks orthochoanitic, connecting rings thick and layered (from King 1998).

Cyclostomiceras profilstrandense sp. nov. urn:1sid:zoobank.org:act:538BB8F6-F83E-47EA-A28F-AD4E316CDAFC

Fig. 5O-Q

\section{Diagnosis}

Small Cyclostomiceras with adult conch width of ca $14 \mathrm{~mm}$, slightly depressed conch cross section; ornamented with shallow, widely spaced, directly transverse annulations.

\section{Etymology}

Referring to the type locality.

\section{Type material}

\section{Holotype}

Specimen FMNH-P30336, by monotypy.

\section{Type locality and horizon}

Profilstranda section, adjacent to Hinlopenstretet, Spitsbergen, from bed Po123.3, $120.3 \mathrm{~m}$ above base of Olenidsletta Member, V2a trilobite zone, Blackhillsian, Floian.

\section{Description}

Specimen FMNH-P30336 is a fragment of part of the phragmocone and a nearly complete body chamber. At the base of the body chamber the cross section is slightly depressed, the conch height is $11.8 \mathrm{~mm}$, the width $12.3 \mathrm{~mm}(\mathrm{rW}=1.08)$. The maximum conch width is $13.7 \mathrm{~mm}$ and reached at ca mid-length of the body chamber. The length of the body chamber is $11 \mathrm{~mm}$, and its aperture is simple transverse and slightly contracted with a width of $13.5 \mathrm{~mm}$ (angle of expansion of conch width $6^{\circ}$ ).

The conch surface is ornamented with widely rounded annuli which have a distance of ca $3 \mathrm{~mm}$ in distance (ca 0.25 of corresponding conch height). Additionally, distinct, irregularly spaced growth lines occur. The annuli and the growth lines form a shallow hyponomic sinus at the prosiphuncular side of the conch.

The chamber spacing is narrow with a distance between two septa of ca $1.3 \mathrm{~mm}$ at an assumed conch height of ca $11 \mathrm{~mm}$. The sutures form a very shallow lateral lobe. The siphuncle is preserved in the last chamber, and has a thickness of ca $1.1 \mathrm{~mm}$ and a distance from the conch margin of $0.8 \mathrm{~mm}$ and is presumably tubular. 


\section{Comparison}

The conch shape and conch dimensions are almost identical to those of Cyclostomiceras minimum (Whitfield, 1886) from the Fort Cassin Formation, Vermont, USA (see Ulrich et al. 1943). However, the new species differs in possessing a weakly ornamented conch surface.

Order Endocerida Teichert, 1933

Family Proterocameroceratidae Kobayashi, 1937

Genus Proterocameroceras Ruedemann, 1905

\section{Type species}

Orthoceras brainerdi Whitfield, 1886, from Fort Cassin Formation, Floian, at Fort Cassin headland, Vermont; by original designation.

\section{Diagnosis}

Slender, gradually expanding orthocones with broadly elliptically depressed cross section; short chambers; sutures directly transverse, slightly sinuous, forming gentle dorsal and ventral lobes; siphuncle large, almost marginal, circular cross section; connecting ring thick, concave segments; septal necks curved orthochoanitic to loxochoanitic; endosiphuncular deposits form endocones with narrow endosiphotube and three endosiphoblades (after Flower 1941; Ulrich et al. 1944: 55; Teichert 1964: K166).

\section{Remarks}

Numerous species have been assigned to Proterocameroceras, especially from the Early and Middle Ordovician of Russia (Balashov 1962, 1968) and South China (Xu \& Lai 1987); some of them differ strongly from the type species. Proterocameroceras valhallfonnense sp. nov. (see below) is one of these forms. A revision of this genus is therefore desirable, but not within the scope of this monograph.

Proterocameroceras valhallfonnense sp. nov. urn:Isid:zoobank.org:act:A94148C2-2CBC-438E-B4C9-36EAE5161A76

Figs 9H-I, 10B-D, 11C

\section{Diagnosis}

Slender orthocones with smooth shell and with weakly depressed conch cross section with a relative conch width (rW) of ca 1.1-1.2; chambers are relatively widely spaced, ca four-six chambers occur per distance similar to the corresponding conch height; the siphuncle is ca $1 / 3$ of the diameter of the corresponding conch height.

\section{Etymology}

From Valhallfonna Glacier, referring to the type region of this species.

\section{Type material}

\section{Holotype}

Specimen FMNH-P30427.

\section{Paratypes}

Specimens FMNH-P30277 and P30429 from type locality and horizon. 
KRÖGER B. \& POHLE A., Ordovician Spitsbergen cephalopods

\section{Type locality and horizon}

Profilstranda section, adjacent to Hinlopenstretet, Spitsbergen, bed PO 131, $128 \mathrm{~m}$ above base of Olenidsletta Member, V2b trilobite zone, Blackhillsian, Floian.

\section{Description}

The holotype is the most complete fragment of this species; it is a $21 \mathrm{~mm}$ long fragment of a phragmocone which grows from 10-12 $\mathrm{mm}$ in conch height with an angle of expansion of $5.5^{\circ}$ (Fig. 9H-I). It has a slightly depressed conch cross section and a well-preserved smooth conch surface. The chambers have a distance of ca $2.5 \mathrm{~mm}$ at a corresponding conch height of $10 \mathrm{~mm}(\mathrm{rCL}=0.25)$. The diameter of the siphuncle is $4 \mathrm{~mm}(\mathrm{rSD}=0.4)$ with slightly concave siphuncular segments. The connecting ring is poorly
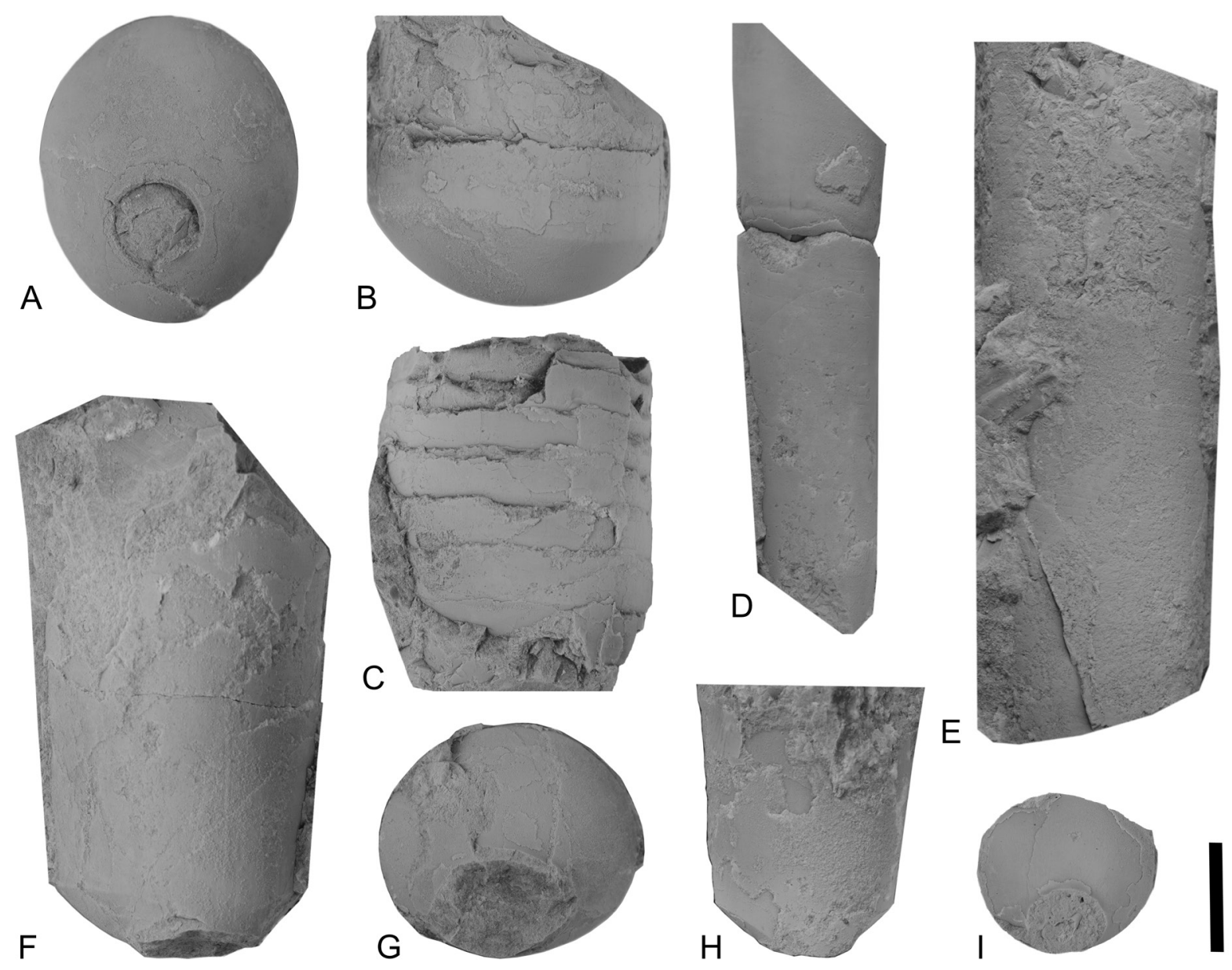

Fig. 9. Orthoconic cephalopods with large siphuncles from the Olenidsletta Member, Floian, Ordovician, Profilstranda section, Ny Friesland, Spitsbergen. A-B, D-E. Buttsoceras buldrebreenense sp. nov. A-B. Specimen FMNH-P30422, from bed PO 131. A. Adoral view of septum and septal perforation. B. Lateral view with prosiphuncular side toward right. C. Cyptendoceratid genus and species indet., FMNH-P30431, from bed PO 131. D. Specimen FMNH-P30423, from bed PO 131, lateral view. E. Specimen FMNH-P30421, holotype, lateral view, note faint transverse ornament partly preserved. F-G. Cyptendoceras sp. A, FMNH-P30426, from bed PO 07. F. Ventral view, prosiphuncular side. G. Adoral view of septum and septal perforation. H-I. Proterocameroceras valhallfonnense sp. nov., FMNH-P30277, from bed PO 131. H. Ventral view, prosiphuncular side. I. Adoral view of septum and septal perforation. Scale bar $=10 \mathrm{~mm}$ for all figures. 
preserved but where visible of moderate thickness. The septal necks are loxochoanitic to orthochoanitic with a length of ca 0.28 of the corresponding chamber length. The siphuncle is filled with asymmetric endocones which are more pronounced and reach ca $30 \mathrm{~mm}$ toward the aperture at the ventral side and only ca $15 \mathrm{~mm}$ at the dorsal side (Fig.10C).

The shell of the other two specimens is slender, orthoconic with a smooth surface and a slightly elliptically depressed cross section. In specimen FMNH-P30277 a conch height of $13.5 \mathrm{~mm}$ relates to a width of ca $14.5 \mathrm{~mm}$, and in the specimen FMNH-P30429 the conch height is $17 \mathrm{~mm}$, where the conch width is $20 \mathrm{~mm}(\mathrm{rW}=1.07,1.18$ respectively).

The siphuncle is circular in cross section and positioned close to the conch margin, with a diameter of $5 \mathrm{~mm}$ in specimen FMNH-P30277 and $6 \mathrm{~mm}$ in specimen FMNH-P30429 (rSD = 0.37 and 0.35, respectively). The exact angle of expansion cannot be measured in either specimen because of the fragmentary preservation.

In specimen FMNH-P30277 the preserved septum is obliquely transverse, shifted toward the aperture at the antisiphuncular side of the conch. The suture forms a broad saddle at the lateral flanks, a broad shallow lobe at the dorsum and a pronounced broad u-shaped lobe at the venter. More details of septa and siphuncle are preserved in the specimen FMNH-P30429, which has a chamber distance of $3 \mathrm{~mm}$ (ca six chambers occur per distance similar to the corresponding conch height) and loxochoanitic to orthochoanitic septal necks which are ca $0.7 \mathrm{~mm}$ long, where measurable (Figs 10D, 11C). The shape of the siphuncular segments and the thickness of the connecting ring cannot be determined with certainty in specimen FMNH-P30277 because of poor preservation.
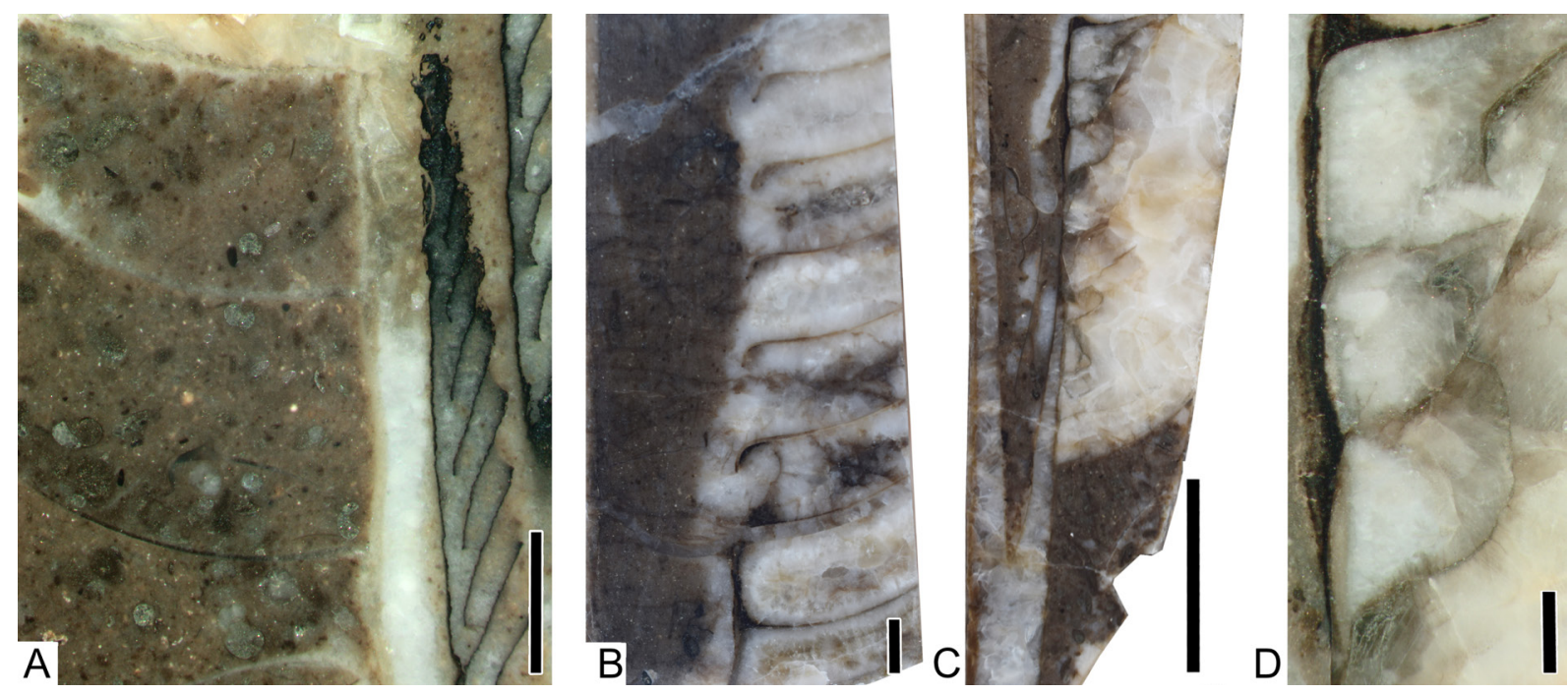

Fig. 10. Median section of orthocones from bed PO 131 of the Olenidsletta Member, Floian, Ordovician, Profilstranda section, Ny Friesland, Spitsbergen. A. Catoraphiceras sp., FMNH-P30425, with graptolite trapped in siphuncle. B-D. Proterocameroceras vallhallfonnense sp. nov. B. Specimen FMNH-P30429. C-D. Holotype, specimen FMNH-P30427. C. Complete specimen with asymmetric endosiphuncular deposits and imploded septa. D. Detail of holotype showing dorsal side of connecting ring and septal necks. Scale bars: A-B $=2 \mathrm{~mm} ; \mathrm{C}=10 \mathrm{~mm} ; \mathrm{D}=1 \mathrm{~mm}$. 


\section{Comparison}

The placement of this new species in Proterocameroceras is somewhat provisional, because the endosiphuncular deposits are poorly known and preserved. Characters of the endocones, such as the presence of endosiphoblades (Teichert 1964: K166) and of an endosiphotube (Ulrich et al. 1944) are explicitly mentioned in the genus diagnosis (see above), but they are not preserved in the material described herein. Furthermore, $P$. valhallfonnense sp. nov. differs from the type species and from other Early Ordovician species of Proterocameroceras in having relatively widely spaced septa. In P. brainerdi, e.g., ca 10-12 chambers occur at a distance similar to the corresponding diameter.

Two species assigned to Proterocameroceras from the Middle Ordovician of the Baltica paleocontinent, from Mishina Gora, western Russia, have a septal spacing which is comparable to that of $P$. valhallfonnense. Of these, $P$. gdovense Balashov, 1968 differs in having nearly tubular siphuncular segments and a thin connecting ring, and P. mishinagorense Balashov 1968 has a lower angle of expansion. In both species from western Russia the siphuncle is narrower, measuring only ca $1 / 3$ of the conch diameter (Balashov 1968).

Order Riocerida King \& Evans, 2019

Family Rioceratidae Kröger \& Evans, 2011

\section{Diagnosis}

Slender, orthocones with essentially simple, straight, transverse sutures and thin marginal, or nearly so siphuncle; sutures may form ventral lobe; septal necks achoanitic through loxochoanitic to nearly orthochoanitic; siphuncular segments concave, with thick connecting rings; endosiphuncular and cameral deposits unknown; diaphragms may be present in some forms (from Kröger \& Evans 2011).

\section{Remarks}

The Rioceratidae were erected to include Rioceras Flower, 1964, Felinoceras Kröger \& Evans, 2011, Microbaltoceras Flower, 1964, and Pachendoceras Ulrich \& Foerste, 1936. Rioceras and Felinoceras, but not Pachendoceras (which is better interpreted as an ellesmerocerid of different affinity, see discussion in Evans \& King 2012, and below), are longitudinally faintly curved with the siphuncle at the concave side of the curvature, and are hence slightly endogastrically curved. The direction of the curvature of
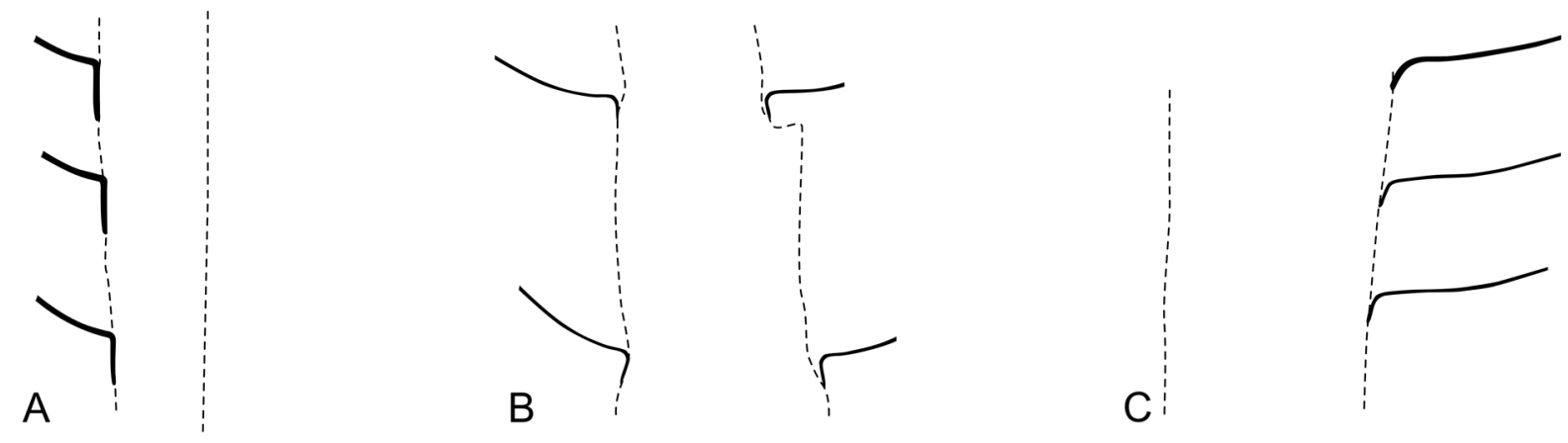

Fig. 11. Reconstruction and interpretation of details of connecting ring and septal necks in orthoconic cephalopods from the Olenidsletta Member, Floian, Ordovician, Profilstranda section, Ny Friesland, Spitsbergen. A. Order, genus and species indet. B, FMNH-P30424, see also Fig. 49A. B. Buttsoceras buldrebreenense sp. nov., FMNH-P30421, holotype, see also Fig. 35A. C. Proterocameroceras vallhallfonnense sp. nov., FMNH-P30429, see also Fig. 10B. Without scale. 
the conch is - as well as their loxochoanitic septal necks - the rationale behind classifying the newly erected, slightly endogastrically curved, partly annulated longiconic genera of the Olendisletta Member within the Rioceratidae and not within the closely similar Rudolfoceratidae Ulrich, Foerste, Miller \& Unklesbay, 1944 (see also below). Kröger \& Landing (2009) revived the Rudolfoceratidae for a group of annulated, breviconic to longiconic ellesmerocerids with slightly exogastrically curved conchs, with thin connecting rings with concave segments (see also Evans 2011). The group with high probability comprises a paraphyletic set of genera which can be phylogenetically positioned basal to the Orthocerida and Dissidocerida Zhuravleva, 1964 (see below). The paraphyletic grouping is also evident by the presence of a spherical protoconch in Ethanoceras gen. nov. and a cup-shaped apex in Svalbardoceras gen. nov. (see below). Further studies and new finds with early ontogenies preserved are needed in order to better resolve the phylogenetic relationships of the genera which are now placed within the Rioceratidae.

Genus Ethanoceras gen. nov.

urn:1sid:zoobank.org:act:7D492453-6BC0-4F56-8DD4-806D508E9DD4

\section{Type species}

Ethanoceras solitudines gen. et sp. nov. from the Olenidsletta Member, V2 trilobite zone, Blackhillsian, Floian; by monotypy.

\section{Diagnosis}

Longiconic orthocones with angle of expansion of ca $5^{\circ}$, with circular conch cross section; shell surface ornamented with distinctive, narrowly spaced transverse striae; strongly eccentrically positioned siphuncle with relative siphuncle diameter $\mathrm{rSD} \approx 0.16$; septal necks relatively long, s-shaped orthochoanitic to loxochoanitic; connecting rings are thick and slightly s-shaped in sagittal section; cameral and endosiphuncular deposits not known.

\section{Etymology}

Referring to Ethan, the name of a Svalbard reindeer, Rangifer tarandus platyrhynchus (Vrolik, 1829), browsing at the Profilbekken area during the summer of 2017.

\section{Comparison}

Ethanoceras gen. nov. differs from other Rioceratidae in having a siphuncle that is completely detached from the conch margin. Specimens of Ethanoceras gen. nov. with conch cross section diameter $<6$ $\mathrm{mm}$ can be distinguished from Bactroceras boliviensis Aubrechtová, 2015 in having only a very weak transverse ornamentation and a distinctive septal neck. Nevadaceras conicum Flower, 1968 differs in having a compressed conch cross section and a slightly expanded siphuncle with thin connecting rings. In Michelinoceras toquimense Flower, 1968 the siphuncle is strictly tubular and eccentrically positioned on the convex side of the conch curvature. The shape of the septal necks of Ethanoceras solitudines gen. et sp. nov. is unique among the Rioceratidae and related taxa; it is morphologically transitional to species with relatively long and partly curved septal necks such as Hemichoanella canningi Teichert \& Glenister, 1954 and Lebetoceras oepiki Teichert \& Glenister, 1954, known from late Tremadocian-early Floian beds of the Emanuel Formation, Western Australia.

Ethanoceras solitudines gen. et sp. nov. urn:Isid:zoobank.org:act:6627FF29-392E-46AF-89AC-D4528B10385A

Figs 12I, 13A, 14-15, 16A

\section{Diagnosis}

Same as for genus, by monotypy. 


\section{Etymology}

From the Latin 'solitudine', 'loneliness'.

\section{Type material}

\section{Holotype}

Specimen FMNH-P30383.

\section{Paratypes}

Twenty-five specimens (P20265, P30191, P30384 to P30404, P30406, P30433, P30435, P30436; see Supp. file 1 for list of specimens): twenty-two from bed PO 123.3, and three from bed PO 131 Profilbekken section, adjacent to Hinlopenstretet; 120.3 and $128 \mathrm{~m}$ above base of Olenidsletta Member, V2 trilobite zone, Blackhillsian, late Floian. Five additional microscopic specimens (FMNH-P30173, P30174, P30192, P30423, P30463) from bed PO 123.3.

\section{Type locality and horizon}

Profilstranda section, adjacent to Hinlopenstretet, bed PO 131, $128 \mathrm{~m}$ above base of Olenidsletta Member, V2 trilobite zone, Blackhillsian, late Floian.

\section{Description}

The holotype is a $40 \mathrm{~mm}$ long orthoconic fragment of a phragmocone with a diameter of 3.4-6.1 $\mathrm{mm}$; it has a circular conch cross section and an apical angle of ca $4^{\circ}$. This is similar in the entire sample. The total sample has a circular conch cross section and a mean angle of expansion of $4^{\circ}\left(1^{\text {st }}-3^{\text {rd }}\right.$ quantile: $\left.3^{\circ}-5^{\circ} ; n=10\right)$ (Fig. 14). The angle of expansion continuously decreases with growth and with maximum values in those fragments with the smallest diameters (Fig. 14).

The conch surface is ornamented with very fine but distinctive, narrowly and irregularly spaced striae (Fig. 13A). In the holotype ca 10-12 striae occur per one millimeter; these are directly transverse.

The relative chamber length ( $\mathrm{rCL}$ ) varies between 0.3 and 0.6 in the macroscopic specimens and is ca 0.55 in the holotype (Fig. 14). The microscopic fragments have relative chamber lengths of $0.6-0.8$, indicating a decrease in rCL during ontogeny. The siphuncle is positioned between the conch center and conch margin with a rSP of $0.08-0.12$, except in the fragments with the smallest diameter preserved, where the maximum rSP is 0.18 at a conch diameter of $2.2 \mathrm{~mm}$ (specimen FMNH-P30463). The measurements indicate a slight shift of the siphuncle from more detached positions in early growth stages toward more marginal positions in later growth stages. The relative diameter of the septal perforation (rSD) varies between 0.16 and 0.21 ; it is ca 0.16 in the holotype (Fig. 14).

The septal necks are uniquely shaped and relatively long: in specimens FMNH-P30395 and FMNH-P30394, where the conch diameter is ca $5 \mathrm{~mm}$, the septal perforation is $0.8 \mathrm{~mm}$, and the chamber length is ca $1.8 \mathrm{~mm}$, the length of the septal neck is $0.4-0.5 \mathrm{~mm}(0.2-0.3$ of corresponding chamber length). The necks are s-shaped at the dorsal (toward the conch center) side of the connecting ring and have a loxochoanitic distal tip (Figs 15, 16A). At the ventral (toward the conch margin) and lateral sides the necks are loxochoanitic.

The connecting ring is relatively thick. Where the siphuncle is $0.8 \mathrm{~mm}$ in diameter, the thickness of the connecting ring is ca $0.13 \mathrm{~mm}$ and it is slightly s-shaped, with the maximum diameter of the connecting ring segment within the adapical third of the chamber.

The protoconch is preserved in specimen FMNH-P30173, a slightly curved fragment with a length of $8 \mathrm{~mm}$ which shows traces of a very fine transverse striation at its adoral end. The protoconch is spherical 
European Journal of Taxonomy 783: 1-102 (2021)

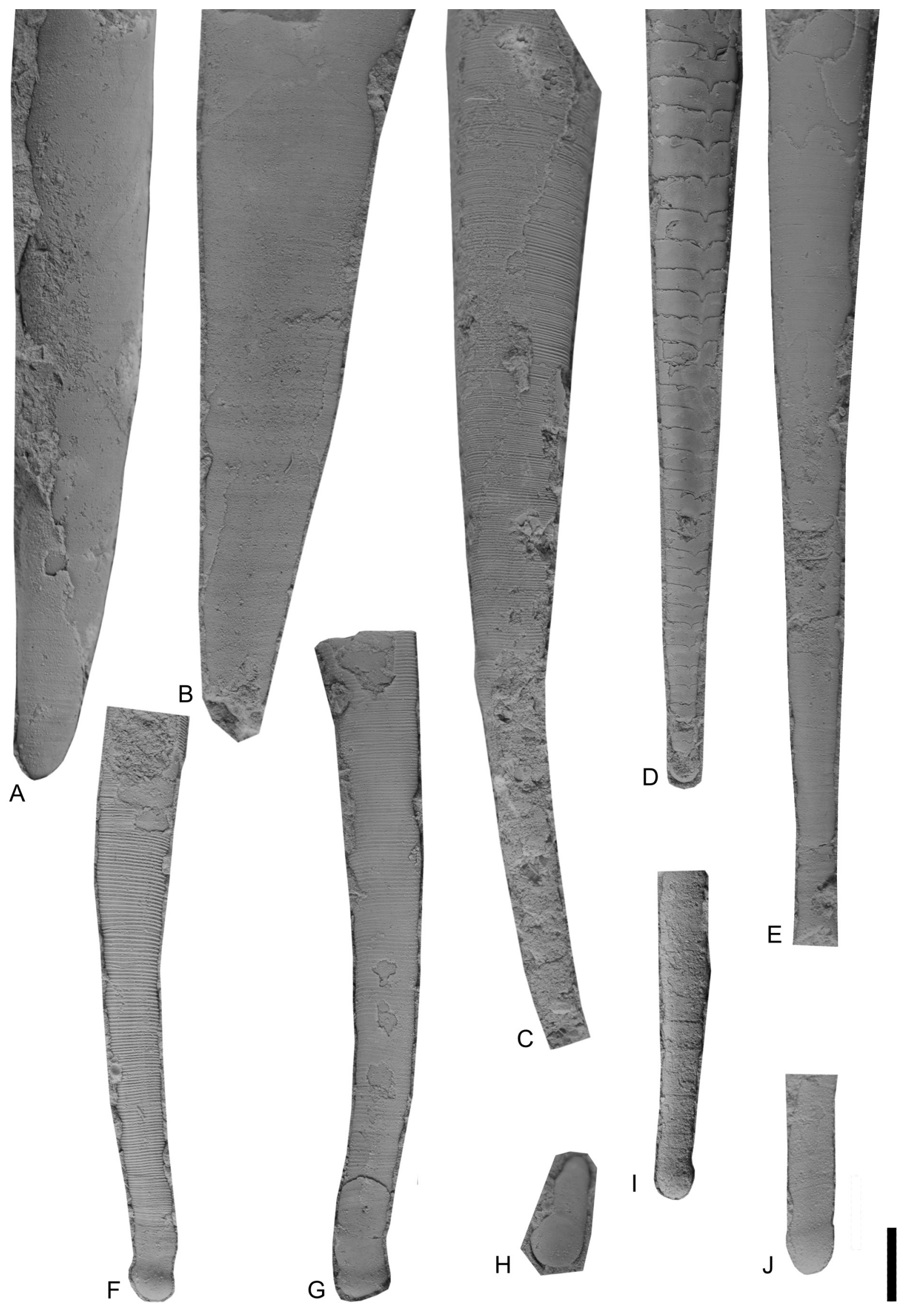


with a diameter of $0.9 \mathrm{~mm}$ and distinguished from the shaft by a distinctive constriction with a diameter of $0.8 \mathrm{~mm}$. The maximum diameter of the fragment is ca $1.4 \mathrm{~mm}$. The chamber lengths are difficult to evaluate, but apparently the first two or three chambers have a length of $0.5-0.6 \mathrm{~mm}$, the fifth and sixth chambers are shortened, with a distance of $0.4-0.5 \mathrm{~mm}$ only, and the subsequent chambers have a length of ca $0.7 \mathrm{~mm}$.

\section{Remarks}

The single apical fragment with a protoconch preserved can be assigned to Ethanoceras solitudines gen. et. sp. nov. because several fragments of this species exist which preserve intermediate growth stages from different individuals. These pieces can be assembled together, helping to reconstruct the complete early growth of this species. The early growth stages are very similar to those of Bactrites boliviensis in general shape and dimensions, and differ mainly in having a higher rate of expansion at sections just adoral to the protoconch (the shaft), where B. boliviensis is almost tubular and E. solitudines gen. et sp. nov. grows with an angle of ca $4-7^{\circ}$.

\section{Stratigraphic and geographic range}

$\mathrm{V}_{2}$ trilobite zone, Olenidsletta Member, Blackhillsian, Floian, Early Ordovician.

Genus Hinlopoceras gen. nov. urn:1sid:zoobank.org:act:1B85F4BE-F04C-4D03-A909-29003ACF507B

\section{Type species}

Hinlopoceras tempestatis gen. et sp. nov. from Olenidsletta Member, V1a trilobite zone, Blackhillsian, Floian.

\section{Diagnosis}

Longicones with slightly curved endogastric curvature during early ontogeny and orthoconic growth during later ontogeny, with cross section changing from circular in juvenile to compressed in adult growth stages; angle of expansion decreases during growth from ca $14^{\circ}$ to $10^{\circ}$; ornamented with distinct transverse growth lines and striae; weak transverse annuli occur during latest growth stages; approximately four chambers occur at a distance similar to the corresponding conch height; siphuncle narrow with diameter ca $1 / 8$ of corresponding conch height, strictly marginally positioned, with slightly concave segments and loxochoanitic septal necks.

Fig. 12 (previous page). Apical parts of orthoconic cephalopods from the Olenidsletta Member, Floian, Ordovician, near Hinlopenstretet, Ny Friesland, Spitsbergen. A. Cyptendoceras sp. B., FMNH-P30472 from Profilbekken river basin, locality PR-phosphatic. Lateral view with siphuncle toward the left. B. Svalbardoceras sterna gen. et sp. nov, FMNH-P30169, from PO 7.5. Lateral view with siphuncle toward left. C, F-G. Eosomichelinoceras borealis sp. nov. C. Specimen FMNH-P30171, from bed PO 123.3. Lateral view with prosiphuncular side toward the right. D. Bactroceras fluvii sp. nov., FMNH-P30168, from Profilbekken river basin, locality PR-phosphatic, showing the ventral side with ventral sutural lobe. E, H, J. Bactroceras boliviensis Aubrechtová, 2015 from bed PO 131. E. Specimen FMNH-P30165, nearly dorsal view, showing the transition of the extreme apical part toward the juvenile part of the conch. F. Specimen FMNH-P30182, lateral view with siphuncle toward the right. G. Specimen FMNH-P30184, lateral view with siphuncle toward the left. H. Specimen FMNH-P30183, apical view, showing the smooth apical surface of the protoconch. I. Ethanoceras solitudines gen. et sp. nov., FMNH-P30173, from bed PO 123.3, note the fine transverse striation. J. FMNH-P30160, showing details of fine transverse ornamentation. Scale bar $=2 \mathrm{~mm}$ for all figures. 


\section{Etymology}

Referring to Hinlopen Strait, Svalbard, the type region of this genus.

\section{Comparison}

The new genus is unique within the Rioceratidae in having a combination of a relatively large angle of expansion, wide septal spacing, and a distinct transversely lirate ornamentation. The internal characters of this genus are relatively poorly known, because most specimens available have a strongly recrystallized phragmocone. The thin marginal siphuncle is nearly tubular or only very slightly concave, which can best be compared with that of Svalbardoceras gen. nov. The consistently poor preservation of the internal shell of specimens of Hinlopoceras gen. nov. in beds where internal features of Svalbardoceras gen. nov. are better preserved indicates that the septa were originally more fragile and sensitive to early dissolution and/or implosion. Species of Hinlopoceras gen. nov. can be distinguished from species of Svalbardoceras gen. nov. by their distinct ornamentation; in Hinlopoceras gen. nov. the conch is ornamented with transverse bands or striae, in Svalbardoceras gen. nov. the ornament consists of fine irregularly spaced growth lines.

Hinlopoceras tempestatis gen. et sp. nov.

urn:1sid:zoobank.org:act:8D1729CE-0726-42C1-85C9-E2AE55BDC1C6

Figs 17D-F, I, 18, 19B

\section{Diagnosis}

Hinlopoceras gen. nov. with cross section changing from circular in juvenile growth stage to ca 0.9 in adult specimen; angle of expansion decreases during growth from ca $14^{\circ}$ to $10^{\circ}$; ornamented with distinct directly transverse, irregularly spaced lirae, 1.5-3 lirae occur per millimeter, and with weak, directly
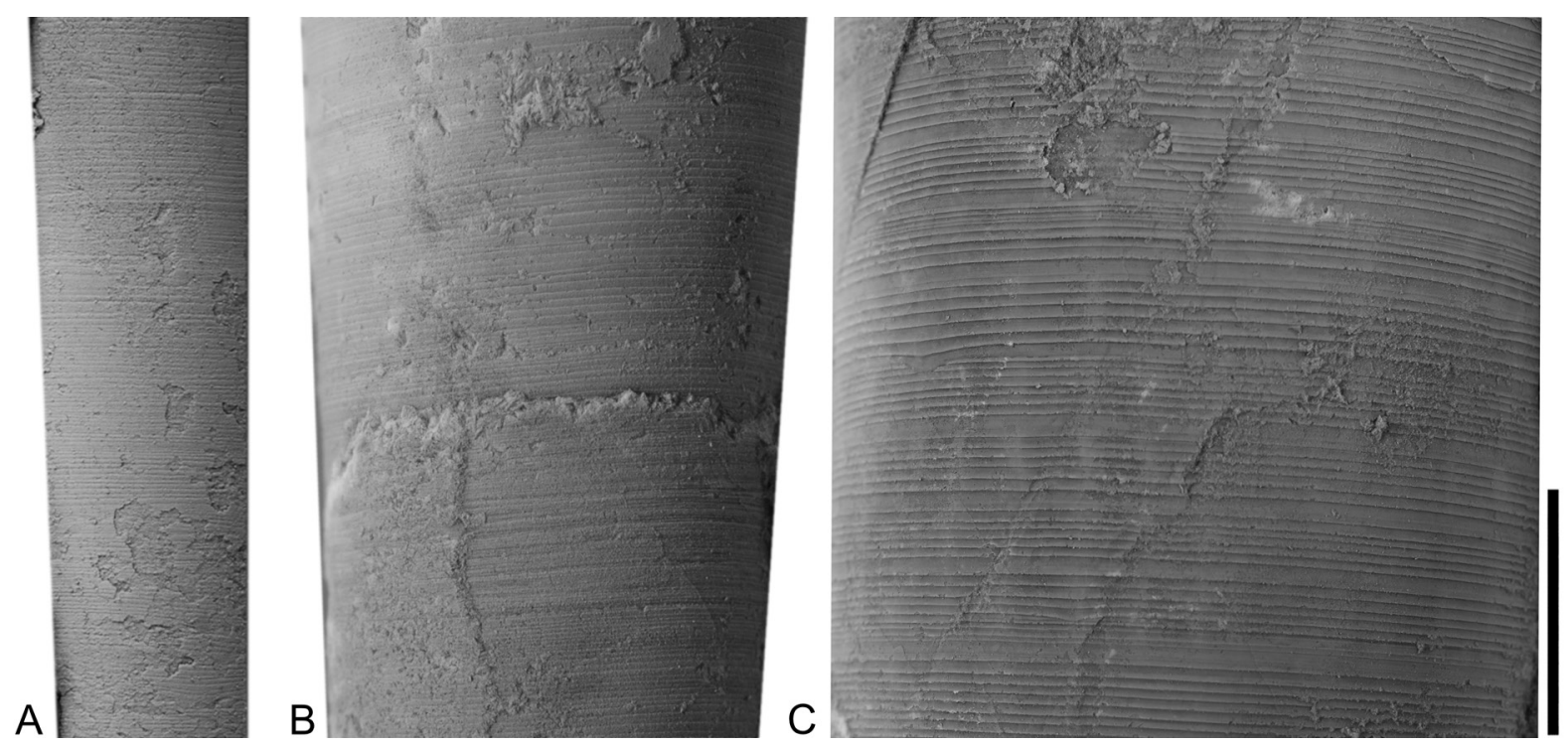

Fig. 13. Details of the conch surface of transversally ornamented orthocones from the Olenidsletta Member, Floian, Ordovician, Profilstranda section, Ny Friesland, Spitsbergen. A. Ethanoceras solitudines gen. et sp. nov., FMNH-P30383, holotype, from bed PO 131. B. Eosomichelinoceras borealis sp. nov., FMNH-P30279, holotype, from bed PO 123.3. C. Bactroceras boliviensis Aubrechtová, 2015, FMNH-P30232, from bed PO 131, conch section with nearly cyclic spacing of transverse striae. Scale $\mathrm{bar}=10 \mathrm{~mm}$ for all figures. 
transverse annulations in latest growth stages. Siphuncle narrow with diameter 0.15 of corresponding conch height, strictly marginally positioned.

\section{Etymology}

From the Latin 'tempestas', 'storm'; referring to its wave-like distinct transversely lirate ornamentation.

\section{Type material}

\section{Holotype}

Specimen FMNH-P30360.

\section{Paratypes}

Fifteen specimens (FMNH-P30450, P30357 to P30359, P30260 to P30269, P30479) all are from type locality and type horizon.

\section{Type locality and horizon}

From Profilstranda section, adjacent to Hinlopenstretet, Spistbergen, from bed PO 07, 4.0 m above base of Olenidsletta Member, V1a trilobite zone, Blackhillsian, Floian.

\section{Description}

The conch is curved and has a cross section that changes from circular during early growth stages, with diameters less than $10 \mathrm{~mm}$, to slightly compressed (rCW ca 0.9 ) in later growth stages (Fig. 18). The conch expands in conch height with an angle of $9^{\circ}-14^{\circ}$ and in conch width from $9^{\circ}$ to $13^{\circ}$. The conch curvature also decreases adorally, with specimens $>10 \mathrm{~mm}$ in conch height having a nearly orthoconic conch with an angle of expansion of ca $10^{\circ}$ (Fig. 18).

The conch ornament consists of distinct, directly transverse lirae which are relatively widely spaced and form a shallow hyponomic sinus on the concave side of the conch curvature (Figs 17D, 19B). In specimen FMNH-P30268 the distance between lirae is $0.3 \mathrm{~mm}$ to $1 \mathrm{~mm}$ where the conch height is $7 \mathrm{~mm}$, and sometimes several subordinate finer lirae occur between two more pronounced lirae.

Two specimens have the siphuncle preserved; in the holotype the siphuncle is marginally positioned at the concave side of the conch curvature, and $0.4 \mathrm{~mm}$ wide where the conch cross section is $2.9 \mathrm{~mm}$. In specimen FMNH-P30365 the siphuncle has a diameter of $1.2 \mathrm{~mm}$ where the conch cross section is
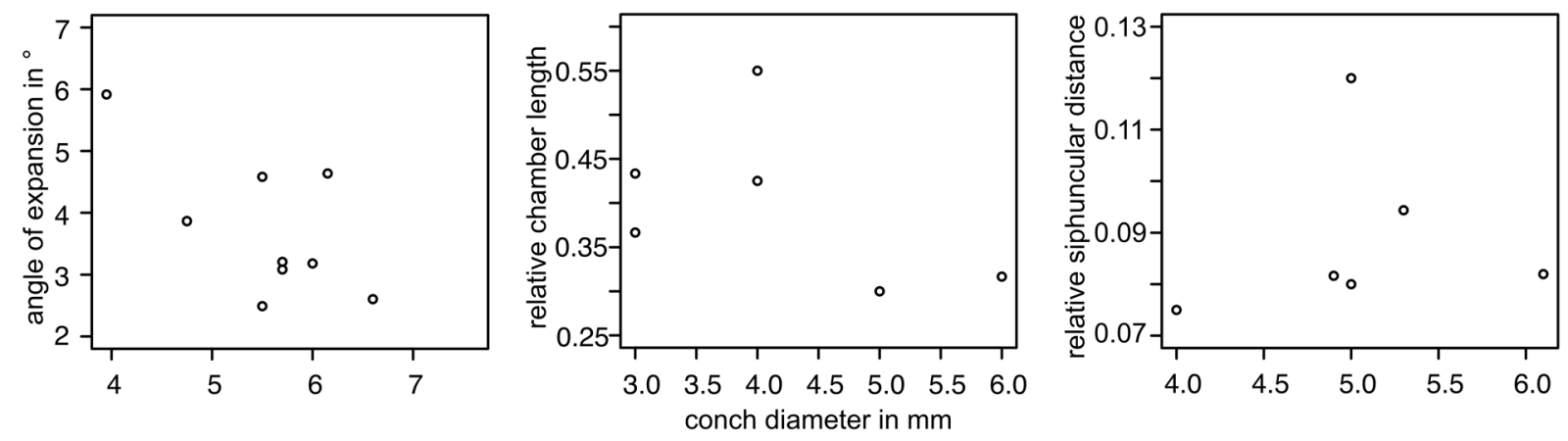

Fig. 14. Diagrams of angle of expansion, relative chamber length, and relative position of siphuncle of Ethanoceras solitudines gen. et sp. nov. from the Olenidsletta Member, Floian, Ordovician, Profilstranda section, Ny Friesland, Spitsbergen. See Supp. file 1, for details of measurements. 
$7.2 \mathrm{~mm}$. The chamber length is known from two specimens only; in the holotype the chamber length is $0.7 \mathrm{~mm}$ at a corresponding conch height of $3 \mathrm{~mm}$, and in FMNH-P30269 the septa have a distance of $1 \mathrm{~mm}$ where the conch is $3.7 \mathrm{~mm}$ in diameter. The largest fragments (specimens FMNH-P30358, FMNH-P30362) have maximum conch heights of $16.4 \mathrm{~mm}$ and $17 \mathrm{~mm}$, respectively, and are ornamented additionally with a weak transverse annulation, which is more pronounced adorally. The distance between the rounded annuli is ca $3 \mathrm{~mm}$ and ca seven lirae occur per cycle of annulation.

\section{Comparison}

See comparison of Hinlopoceras venti gen. et sp. nov.

Hinlopoceras venti gen. et sp. nov. urn:1sid:zoobank.org:act:BFD524AB-81E0-4B03-9467-42F127845E61

Figs $17 \mathrm{G}-\mathrm{H}, \mathrm{J}, 18,19 \mathrm{~A}$

\section{Diagnosis}

Hinlopoceras gen. nov. with cross section changing from circular in juvenile growth stage to slightly compressed $(\mathrm{rW} \approx 0.8)$ in adult specimen; angle of expansion decreases during growth from ca $14^{\circ}$ to $11^{\circ}$; ornamented with distinct irregularly spaced directly transverse lirae which are more pronounced during later growth stages. Siphuncle narrow with $\mathrm{rSD}=0.12$, strictly marginally positioned and with loxochoanitic septal necks.

\section{Etymology}

From Latin 'ventus', 'wind'; referring to its wave-like faint transversely lirate ornamentation.

\section{Type material}

\section{Holotype}

Specimen FMNH-P30266.
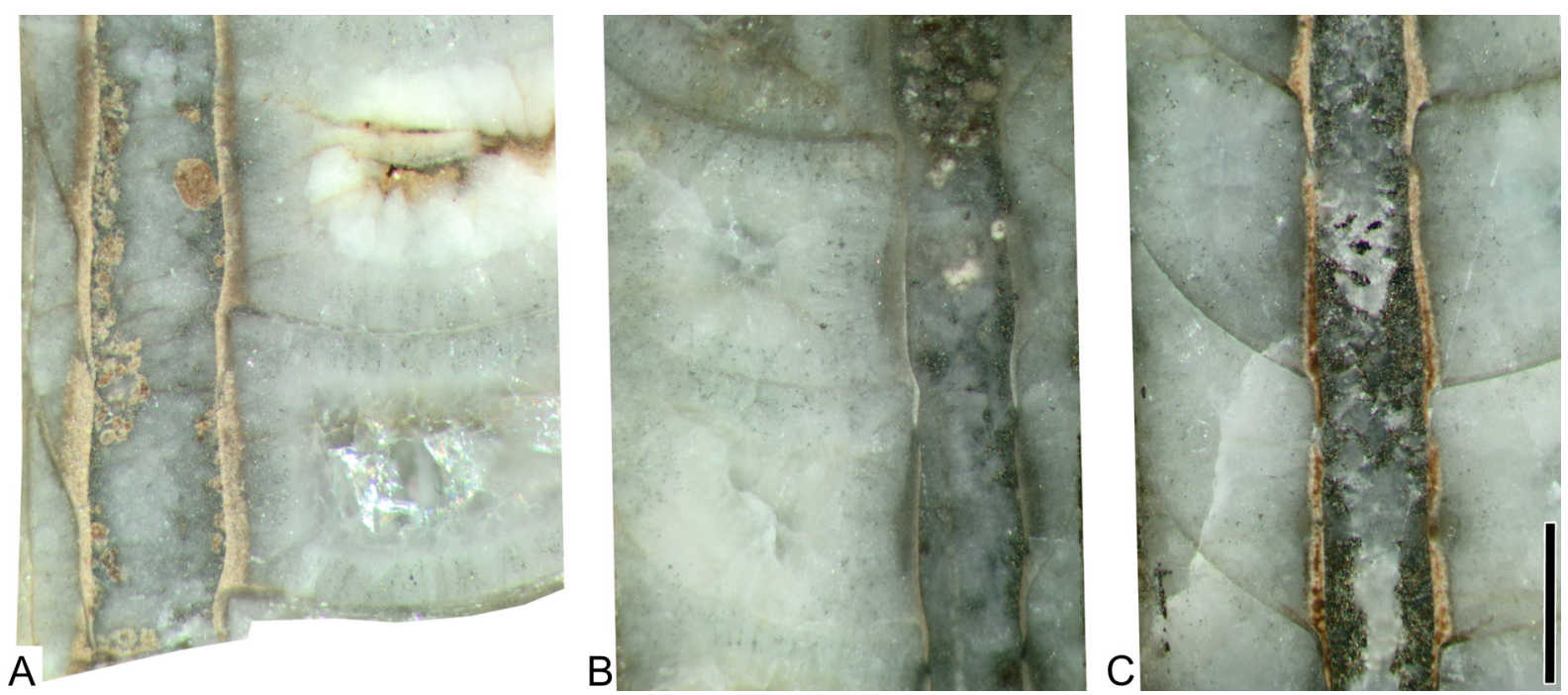

Fig. 15. Median sections of phragmocones of Ethanoceras solitudines gen. et sp. nov. from from bed PO 123.3, Olenidsletta Member, Floian, Ordovician, Profilstranda section, Ny Friesland, Spitsbergen. A. Specimen FMNH-P30394. B. Specimen FMNH-P30406. C. Specimen FMNH-P30395, oblique section roughly dorsal-ventrally oriented with ventral side directed toward the left. Scale bar $=1 \mathrm{~mm}$ for all figures. 


\section{Paratypes}

Two additional specimens from the type locality: FMNH-P30267 from bed PO 7.5 and FMNH-P30262 from bed PO 07, $4.5 \mathrm{~m}$ and $4.0 \mathrm{~m}$ above the base of Olenidsletta Member, V1 a trilobite zone, Blackhillsian, Floian.

\section{Type locality and horizon}

From Profilstranda section, adjacent Hinlopenstretet, Spitsbergen, from bed PO 7.5, 4.5 m above base of Olenidsletta Member, V1a trilobite zone, Blackhillsian, Floian.

\section{Description}

The conch is curved in growth stages less then ca $10 \mathrm{~mm}$, and almost orthoconic in later growth stages; its conch height increases at an angle of $14^{\circ}$ in early growth stages and $11^{\circ}-13^{\circ}$ in later growth stages (Fig. 18). The degree of compression increases during growth, with specimens $>10 \mathrm{~mm}$ in conch height with $\mathrm{rW} \approx 0.9$ or less (Fig. 18).

The ornament consists of transverse lirae which are less pronounced and faint during early growth stages; conch almost smooth in growth stages with conch height $<7 \mathrm{~mm}$; at conch height $>$ ca $9 \mathrm{~mm}$ the lirae are well expressed, with a distance of ca 0.3-0.6 mm (specimens FMNH-P30266, P30267). In specimen FMNH-P30262 the distance between two major lirae is $0.7 \mathrm{~mm}$ with one subordinate lira in between at a conch height of ca $14 \mathrm{~mm}$ (Fig. 19A).

The siphuncle is preserved in the adapical part of specimen FMNH-P30266, where the conch diameter is $3.4 \mathrm{~mm}$ and the siphuncular diameter is $0.4 \mathrm{~mm}$.
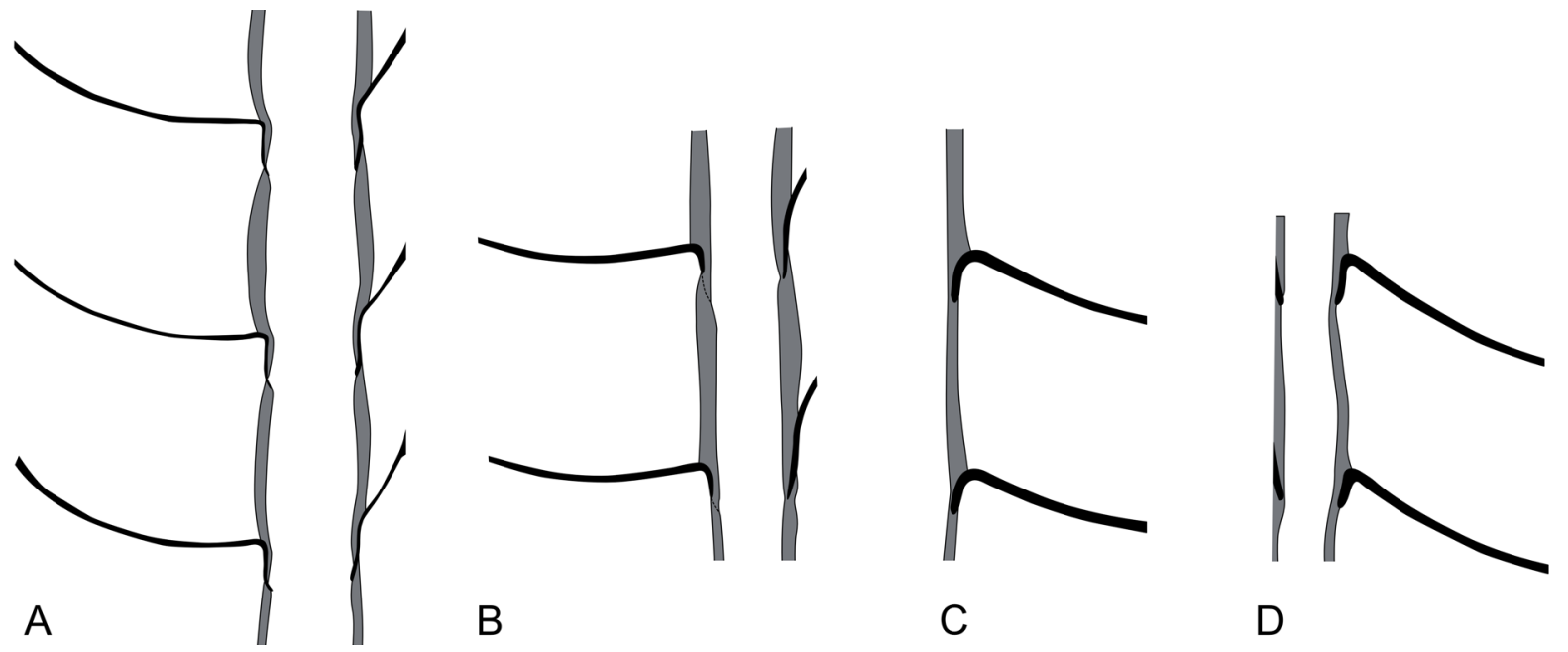

Fig. 16. Reconstruction and interpretation of details of connecting ring and septal necks in rioceratid cephalopods from the Olenidsletta Member, Floian, Ordovician, Profilstranda section, Ny Friesland, Spitsbergen. A. Ethanoceras solitudines gen. et sp. nov., FMNH-P30406, see Fig. 15B. B. Svalbardoceras skua gen. et sp. nov., FMNH-P30274, see Fig. 23F. C-D. Svalbardoceras sterna gen. et. sp. nov., note variability of septal neck shape, which is interpreted as an effect of poor preservation. C. Specimen, FMNH-P30368, see Fig. 23G. D. Specimen, FMNH-P30371, see Fig. 23E. Black: septal neck and septum. Dark grey: connecting ring. Without scale. 

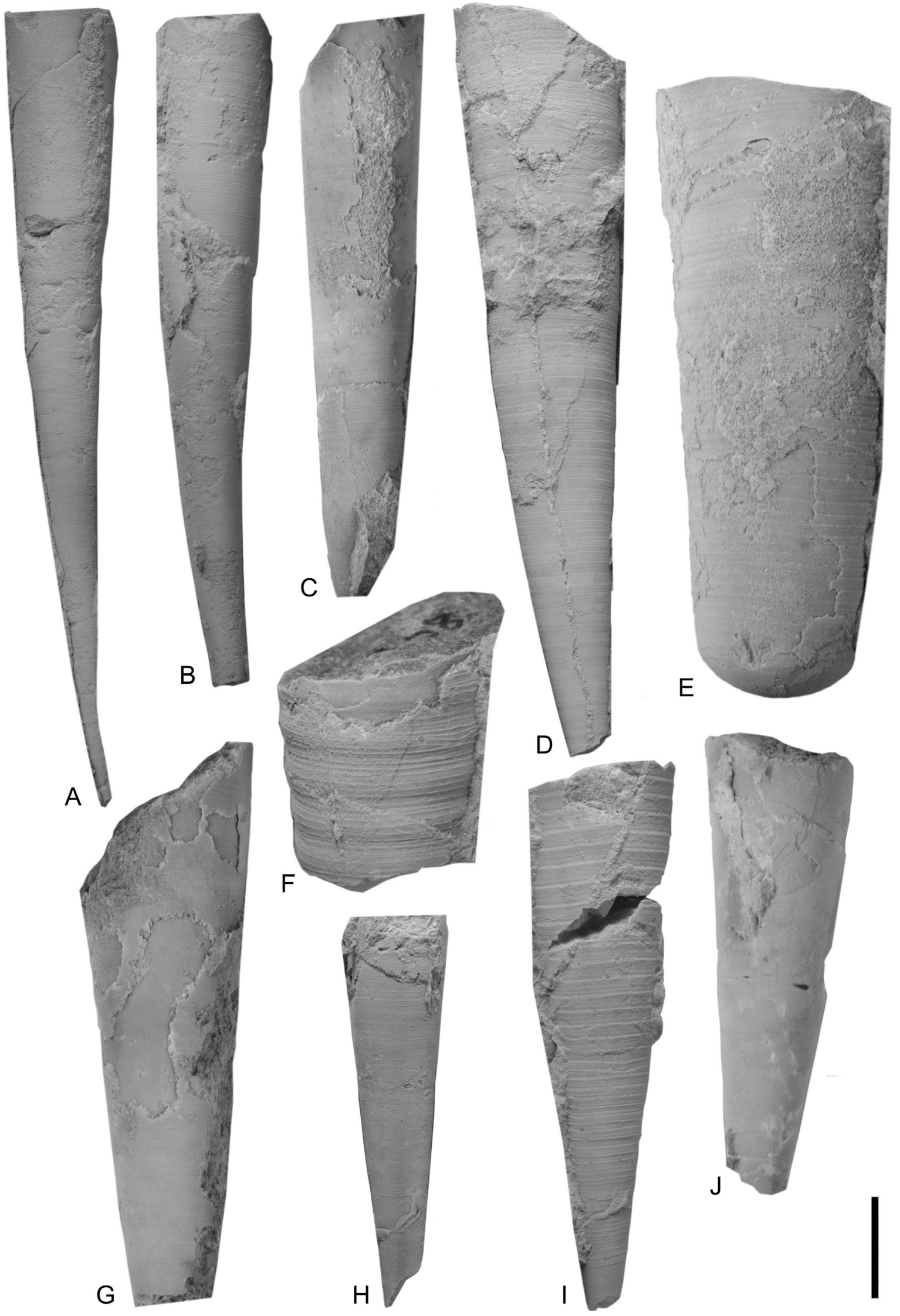


\section{Comparison}

Hinlopoceras venti gen. et sp. nov. differs from H. tempestatis gen. et sp. nov. mainly in its less pronounced ornamentation, which is faint during early growth stages and consists of irregularly spaced transverse lirae of different strength in growth stages with conch height larger than ca 8-9 mm. Hinlopoceras tempestatis gen. et sp. nov. has pronounced lirae throughout its entire growth (except the very adapical ca $10 \mathrm{~mm}$, Fig. 17I) and a clear differentiation between primary and secondary lirae exists throughout its growth. Little is known about the internal characters of $H$. venti gen. et sp. nov. because all specimens of the sample have a strongly recrystallized phragmocone. The general similarity of this species with $H$. tempestatis gen. et sp. nov., however, suggests a similar chamber spacing, siphuncular position and shape.

Genus Svalbardoceras gen. nov. urn:1sid:zoobank.org:act:AE232B80-8CB8-45F8-A9BA-80620CD0D41C

\section{Type species}

Svalbardoceras sterna gen. et sp. nov.; Early Ordovician, late Floian, Olenidsletta Member, Valhallfonna Formation Öland, Spitsbergen.

\section{Diagnosis}

Weakly curved endogastric longicones with angle of expansion $5^{\circ}$ to $7^{\circ}$; shell ornamented with shallow, irregularly spaced undulations, which are more pronounced in later growth stages, and with fine but distinct irregularly spaced directly transverse, imbricate growth lines; three to four chambers occur per distance similar to the corresponding conch cross section; thin marginal siphuncle with $\mathrm{rSD} \approx 1 / 8$ to $1 / 6$, siphuncle marginally, or nearly so, positioned at concave side of conch curvature; septal necks loxochoanitic to orthochoanitic; connecting ring relatively thick with slightly concave segments, almost tubular, endosiphuncular and cameral deposits not known.

\section{Etymology}

Referring to Svalbard, the type region of this genus.

\section{Comparison}

This new genus is unique within the Rioceratidae in having a combination of relatively wide septal spacing, a thin marginal siphuncle and an ornamentation with shallow, irregularly spaced undulations that are more pronounced in later growth stages. The similarly annulated and weakly curved Felinoceras Kröger \& Evans, 2011 differs in having a narrower septal spacing and a distinctive annulation throughout

Fig. 17 (previous page). Rioceratid and orthocerid cephalopods from the Olenidsletta Member, Floian, Ordovician, Profilstranda section, Ny Friesland, Spitsbergen. A-C. Eosomichelinoceras borealis sp. nov., from bed PO 123.3. A. Specimen FMNH-P30278, lateral view with ventral, prosiphuncular side toward left. B. Specimen FMNH-P30279, lateral view with ventral, prosiphuncular side toward left. C. Specimen FMNH-20288, holotype, ventral view. D-F, I. Hinlopoceras tempestatis gen. et sp. nov., from bed PO 07. D. Specimen FMNH-P30359, lateral view with ventral, prosiphuncular side toward right. E. Specimen FMNH-30479, adult(?) body chamber, ventral view, prosiphuncular side. F. Specimen FMNH-P30362, strongly annulated fragment of body chamber. G-H, J. Hinlopoceras venti gen. et sp. nov. G. Specimen FMNH-P30262, from bed PO 07, lateral view with ventral, prosiphuncular side toward left. H. Specimen FMNH-P30266, from bed PO 7.5, lateral view with ventral, prosiphuncular side toward right. I. Specimen FMNH-P30360; note the nearly smooth adapical part of the fragment. J. Specimen FMNH-P30267, from bed PO 7.5, lateral view with ventral, prosiphuncular side toward left. Scale bar $=10 \mathrm{~mm}$ for all figures. 
its growth. Semiannuloceras Evans, 2005 differs in possessing, in addition, a longitudinal ornamentation. The conch of Rioceras Flower, 1964 is smooth throughout its entire growth.

Svalbardoceras sterna gen. et sp. nov.

urn:1sid:zoobank.org:act:F4069C31-5F45-44C0-A05D-03223749C9DE

Figs 12B, 16C-D, 19D, 20-21, 22E-G, 23A, C, E, G

\section{Diagnosis}

Slightly curved longicones with compressed conch cross section; with shallow irregularly spaced undulations that are more pronounced in later growth stages and with fine, irregularly spaced, directly transverse imbricate growth lines which form a shallow hyponomic sinus at prosiphuncular side of the conch; thin marginal siphuncle with $\mathrm{rSD} \approx 0.13$, siphuncle positioned at concave side of conch curvature; septal necks orthochoantic to loxochoantic, connecting ring nearly tubular, weakly concave.

\section{Etymology}

Referring to the laridid genus Sterna Linneaus, 1758, birds which were common companions during our field work at Profilstranda, Ny Friesland.

\section{Type material}

\section{Holotype}

Specimen FMNH-P30368.

\section{Paratypes}

Forty-four specimens (P30368 to P30382, P30437 to P30449, P30451 hasta P30462, P30465, P30466, P30468 to P30470; see Suppl. file 1 for list of specimens) from type locality, two from bed PO 07, fortytwo from bed PO 7.5, $4 \mathrm{~m}$ and $4.5 \mathrm{~m}$ above the base base of the Olenidsletta Member, Valhallfonna Formation, V1a trilobite zone, Blackhillsian, Floian. Two additional specimens (FMNH-P30169, FMNH-P30172) from bed PO 7.5 are apical fragments.

\section{Type locality and horizon}

From Profilstranda section, adjacent to Hinlopenstretet, Spitsbergen, from bed PO 7.5, 4.5 m above the base of the Olenidsletta Member, Valhallfonna Formation, V1a trilobite zone, Blackhillsian, Floian.
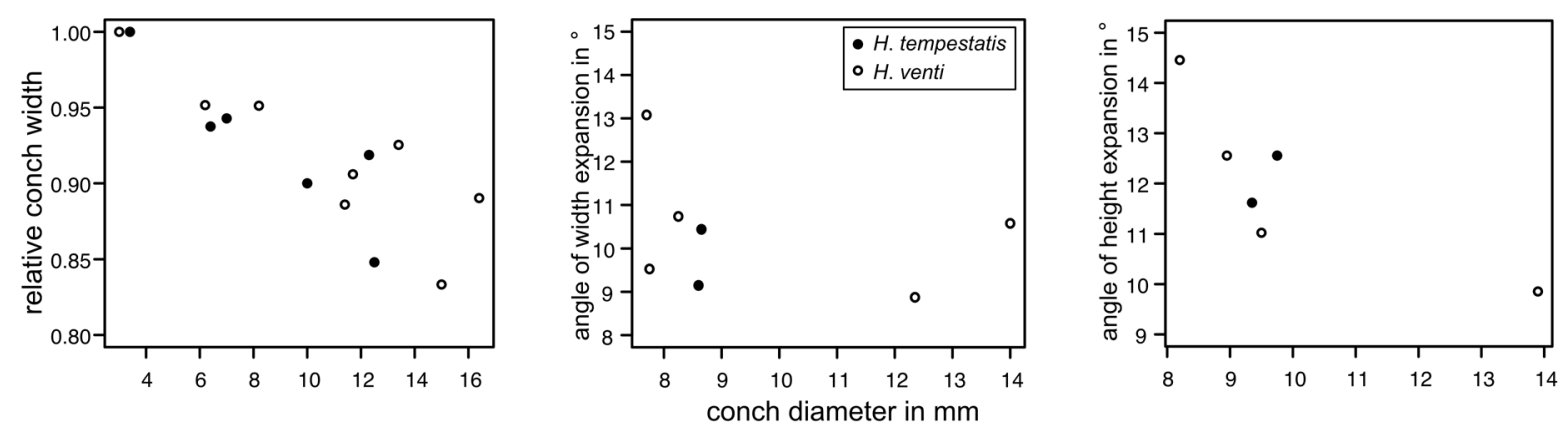

Fig. 18. Diagrams of relative conch width and angles of expansion of species of Hinlopoceras gen. nov. from the Olenidsletta Member, Floian, Ordovician, Profilstranda section, Ny Friesland, Spitsbergen. See Supp. file 1 for details of measurements. 


\section{Description}

The conchs are slightly curved with an angle of expansion of conch width $<$ ca $9^{\circ}$ (mean angle of expansion $=6.7^{\circ}, 1^{\text {st }}-3^{\text {rd }}$ quantile: $5.7-7.8 ; \mathrm{n}=12$ ), and of conch height $<12^{\circ}$ (mean angle of expansion $=$ $7^{\circ}, 1^{\text {st }}-3^{\text {rd }}$ quantile: $\left.6.6-9.3 ; \mathrm{n}=14\right)$. The conchs reach their largest angle of expansion in growth stages with conch heights of $10-17 \mathrm{~mm}$ (Fig. 20). The conch cross section is compressed with a mean $\mathrm{rW}=$ $0.89\left(1^{\text {st }-3^{\text {rd }}}\right.$ quantile: $\left.0.86-0.92 ; n=29\right)($ Fig. 21$)$.

The conch surface is ornamented with growth lines or growth bands and weak irregularly spaced annulations, which are more pronounced in specimens with conch height $>10 \mathrm{~mm}$. Annulation and ornamentation are slightly obliquely transverse, shifted toward aperture at antisiphuncular side and form a shallow hyponomic sinus at the prosiphuncular side. In some specimens, e.g., FMNH-P30379, the conch surface appears to be finely imbricated (Fig. 22E).

The siphuncle is marginal, positioned at the concave side of the conch curvature with a mean $\mathrm{rSD}=0.13$ $\left(1^{\text {st }-3^{\text {rd }}}\right.$ quantile: $\left.0.11-0.15 ; \mathrm{n}=4\right)$. The sutures are directly transverse with an $\mathrm{rCL}$ between 0.27 and 0.36 (Fig. 21).

The septal necks are loxochoanitic to orthochoanitic. The connecting ring is relatively thin and forms slightly concave segments, which can vary within one specimen from nearly tubular to slightly s-shaped (Fig. 23E-G). The largest known specimen is a fragment of a phragmocone, FMNH-P30446, with a maximum diameter of $22 \mathrm{~mm}$.

Two specimens preserve the apical parts of the conch. In the apical $0.5 \mathrm{~mm}$ FMNH-P30169 reaches $1.7 \mathrm{~mm}$ in diameter; increasing to $2.2 \mathrm{~mm}$ at a distance $2 \mathrm{~mm}$ from the apex, and then respectively $3 \mathrm{~mm}$ at $5 \mathrm{~mm}$ and $6 \mathrm{~mm}$ at $17 \mathrm{~mm}$. The conch has a slightly compressed cross section. The extreme ca $0.5 \mathrm{~mm}$ of the apex of specimen FMNH-P30169 was broken during preparation, is poorly preserved and the presence or absence of a cicatrix is not possible to determine.

\section{Comparison}

Svalbardoceras sterna gen. et sp. nov. differs from S. skua gen. et sp. nov. in having a compressed conch cross section. Svalbardoceras sterna gen. et sp. nov. is similar to Bactroceras morguesi Kröger \& Evans,
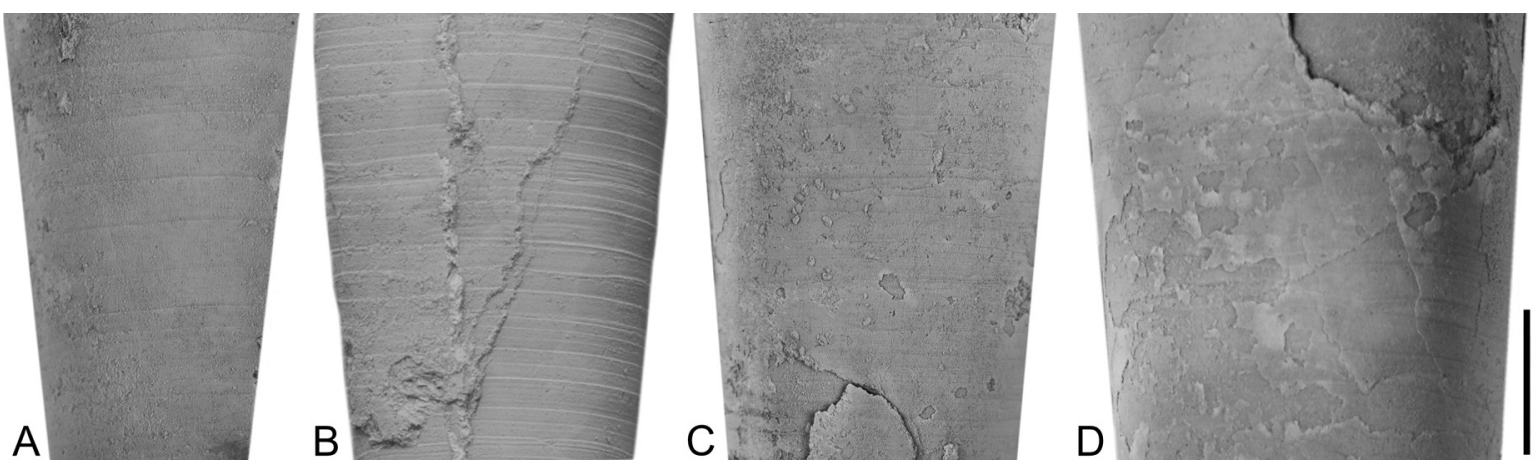

Fig. 19. Details of the conch surface of rioceratid cephalopods from the Olenidsletta Member, Floian, Ordovician, Profilstranda section, Ny Friesland, Spitsbergen. A. Hinlopoceras venti gen. et sp. nov., FMNH- P30262, from bed PO 07, lateral view with ventral, prosiphuncular side toward left. B. Hinlopoceras tempestatis gen. et sp. nov., FMNH-P30359, from bed PO 07, lateral view with ventral, prosiphuncular side toward right. C. Svalbardoceras skua gen. et sp. nov., FMNH-P30408, from bed PO 123.3. D. Svalbardoceras sterna gen. et sp. nov., FMNH-P30373, from bed PO 7.5. Scale bar $=$ $5 \mathrm{~mm}$ for all figures. 
2011 with respect to the angle of expansion and the slight conch curvature, but the latter differs in having a circular conch cross section and in not being annulated.

Svalbardocreas skua gen. et sp. nov.

urn:1sid:zoobank.org:act:9385D872-8656-4B53-9CA8-05F7575BEB6F

Figs 16B, 19C, 20-21, 22A-D, 23B, D, F

\section{Diagnosis}

Slightly curved longicones with circular conch cross section; shell ornamented with shallow, irregularly spaced undulations that are more pronounced in later growth stages and with fine, irregularly spaced, directly transverse growth lines or bands; thin, nearly marginal siphuncle with relative siphuncle diameter of ca 0.16 of corresponding conch cross section, siphuncle positioned at concave side of conch curvature; septal necks orthochoanitic; connecting ring relatively thick with slightly concave segments, weak hyposeptal and episeptal deposits occur.

\section{Etymology}

Referring to Stercorarius skua (Brünnich, 1764), a bird which was a common companion during our field work at Profilstranda, Ny Friesland.

\section{Type material}

\section{Holotype}

Specimen FMNH-P30272.

\section{Paratypes}

Nine specimens from type locality, one from bed PO 123 (FMNH-P30271), eight from bed PO 123.3 (FMNH-P30263, P30264, P30273, P30275 to P30277, P30408, P30471), 120-120.3 m above the base of the Olenidsletta Member, V2a trilobite zone, Blackhillsian, Floian.

\section{Type locality and horizon}

From Profilstranda section, adjacent to Hinlopenstretet, Spitsbergen, bed PO 123.3, $120.3 \mathrm{~m}$ above the base of the Olenidsletta Member, V2a trilobite zone, Blackhillsian, Floian.
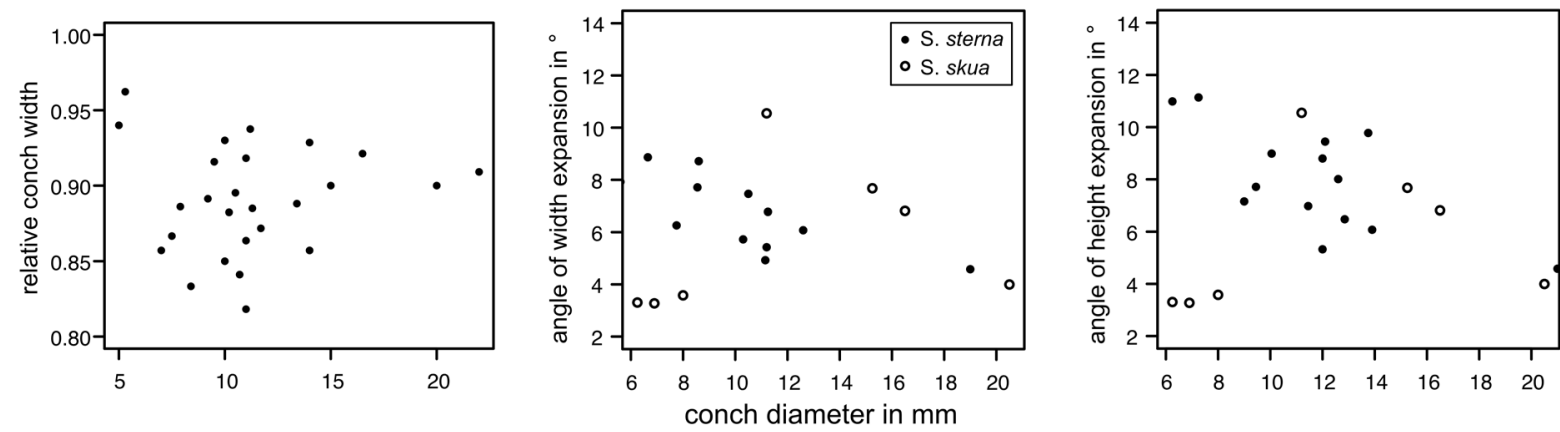

Fig. 20. Diagrams of relative conch width and angles of expansion of species of Svalbardoceras gen. nov. from the Olenidsletta Member, Floian, Ordovician, Profilstranda section, Ny Friesland, Spitsbergen. See Supp. file 1 for details of measurements. 


\section{Description}

The conchs are slightly curved with angle of expansion of $<$ ca $7^{\circ}$ (mean angle of expansion $=4.8^{\circ}$, $1^{\text {st }}-3^{\text {rd }}$ quantile: $3.3-4.8 ; n=7$ ), which decreases with conch size from ca $11^{\circ}$ to $5^{\circ}$ (Figs $20,22 \mathrm{~A}-\mathrm{D}$ ). The conch cross section is invariantly circular.

The conch surface is ornamented with fine growth lines or growth bands (Fig. 29C) and annulations, which are slightly obliquely transverse, and shifted toward the aperture at the antisiphuncular side.

The sutures are slightly obliquely transverse and shifted toward the aperture at the antisiphuncular side. The relative chamber length ( $\mathrm{rCL}$ ) decreases with increasing conch cross section (Fig. 21), ranging from ca 0.25 to more than 0.3 .

The siphuncle is marginally positioned, very slightly removed from the conch margin (Fig. 23B), at the concave side of the conch curvature with a mean rSD of $0.16\left(1^{\text {st }}-3^{\text {rd }}\right.$ quantile: $\left.0.13-0.19 ; n=4\right)$. The septal necks are orthochoanitic. The connecting ring is moderately thick and forms slightly concave siphuncular segments (Fig. 23F). Weak epi-, and hyposeptal deposits occur in the extreme apical part of specimen FMNH-P30274 at a conch height of ca $<2.8 \mathrm{~mm}$. In one specimen part of the body chamber is preserved (specimen FMNH-P30276); the body chamber is $>26 \mathrm{~mm}$ long and the conch diameter at the position of the last septum is $5.5 \mathrm{~mm}$.

\section{Comparison}

See above, under Svalbardoceras sterna gen. et sp. nov.

Family Bactroceratidae King \& Evans, 2019

\section{Emended diagnosis}

Slender orthoconic to weakly cyrtoconic shells with usually faint ornamentation consisting of transverse growth lines or low striae; siphuncle marginal, narrow; dorsomyarian muscle scars; septal necks orthochoanitic to hemichoanitic, connecting rings thin and homogeneous, slightly expanded into chambers; embryonic shell moderately large, subspherical and with constriction; cicatrix absent (slightly modified from King \& Evans 2019).

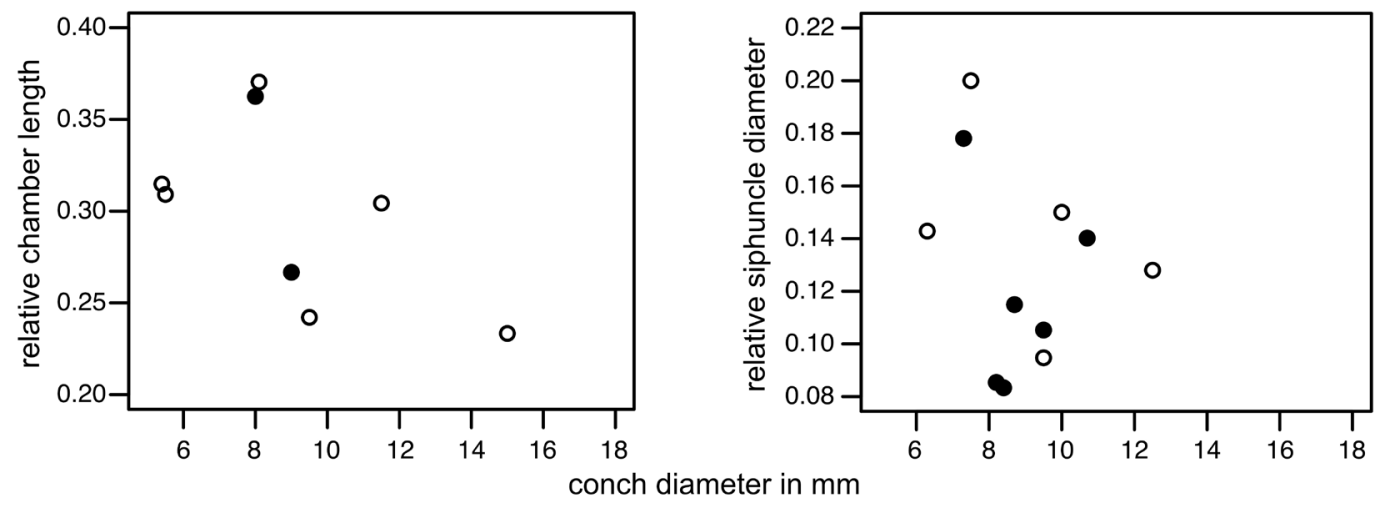

Fig. 21. Diagrams of relative chamber length and relative siphuncular diameter of species of Svalbardoceras gen. nov. from the Olenidsletta Member, Floian, Ordovician, Profilstranda section, Ny Friesland, Spitsbergen. See Supp. file 1 for details of measurements. 


\section{Remarks}

The diagnosis of the Bactroceratidae King \& Evans, 2019 is emended with respect to the statement of a presence or absence of endosiphuncular and cameral deposits, which follows a discussion of the type genus of this family (see below). A statement about the presence or absence of deposits is removed from the diagnosis herein.

Genus Bactroceras Holm, 1898

\section{Type species}

Bactroceras avus Holm, 1898; Middle Ordovician, late Darriwilian Stage, Seby Limestone Formation; Öland, Sweden; by original designation.
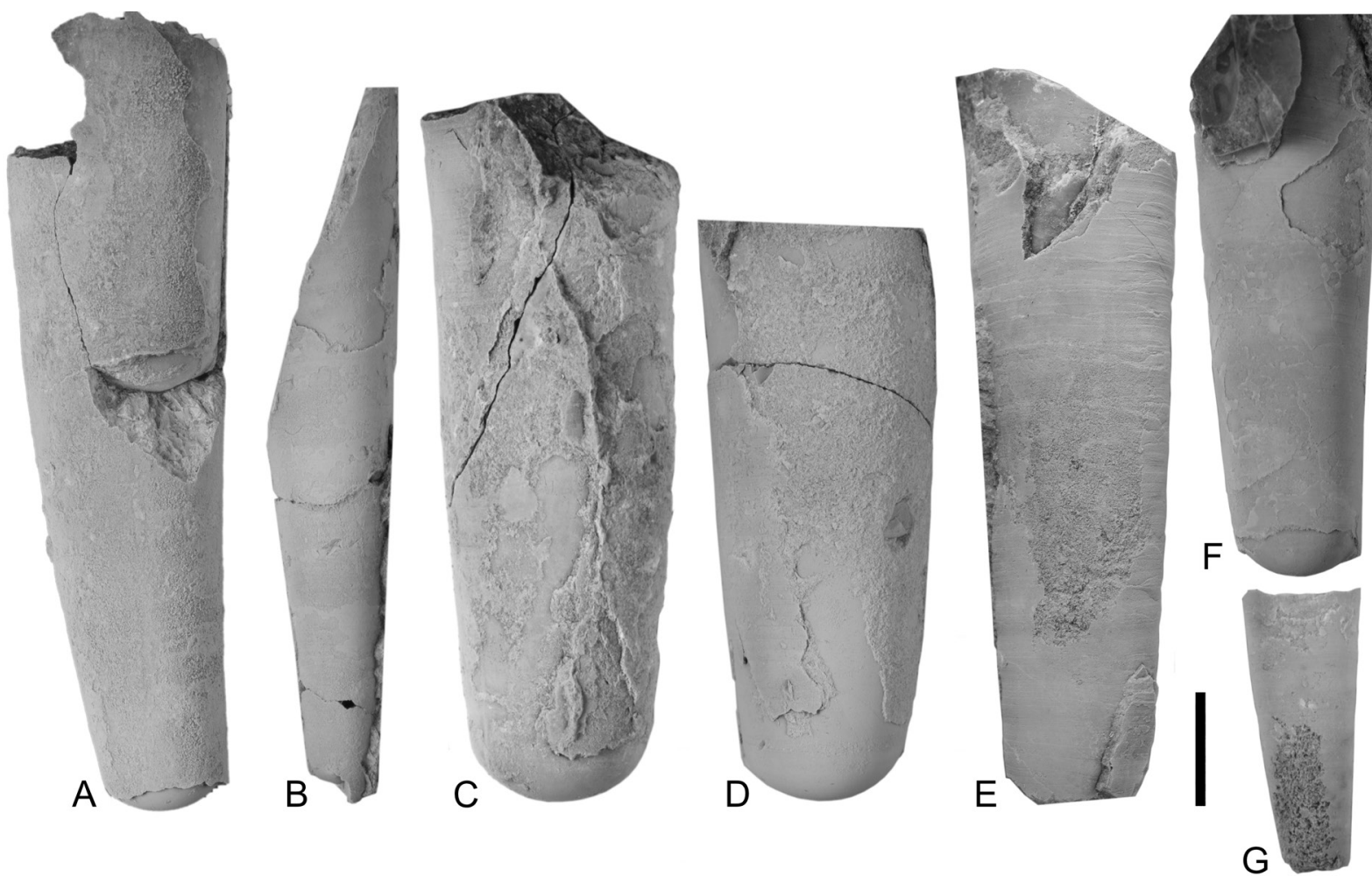

Fig. 22. Svalbardoceras gen. nov. from the Olenidsletta Member, Floian, Ordovician, Profilstranda section, Ny Friesland, Spitsbergen. A-D. Svalbardoceras skua gen. et sp. nov. from bed PO 123.3. A. Specimen FMNH-P30277, lateral view, venter, prosiphuncular side toward the right. B. Specimen FMNH-P30272, holotype, lateral view, venter, prosiphuncular side toward the left. C. Specimen FMNH-P30276, lateral view of adult (?), body chamber, with venter, prosiphuncular side toward the left. D. Specimen FMNH-P30263, lateral view of a fragmentary body chamber, with venter, prosiphuncular side toward the left. E-G. Svalbardoceras sterna gen. et sp. nov., from bed PO 7.5. E. Specimen FMNH-P30379. F. Specimen FMNH-P30373, lateral view with venter, prosiphuncular side toward the right. G. Specimen FMNH-P30368, holotype, lateral view with venter, prosiphuncular side toward the right. Scale bar $=10 \mathrm{~mm}$ for all figures. 


\section{Diagnosis}

Slender, orthocones or weakly curved cyrtocones with sub-circular or circular conch cross section; apical angle low, typically below $10^{\circ}$; surface sculpture with straight, transverse growth lines or annulations, and/or striae; hyponomic sinus broad and shallow; phragmocone chambers rather deep, concavity at least 0.3 of conch height; sutures straight and transverse; distance between two sutures between 0.25 and 0.5 of corresponding conch cross section; siphuncle marginal or slightly removed from shell margin; diameter of the siphuncle between $1 / 7$ and $1 / 20$ of corresponding conch cross section; septal necks
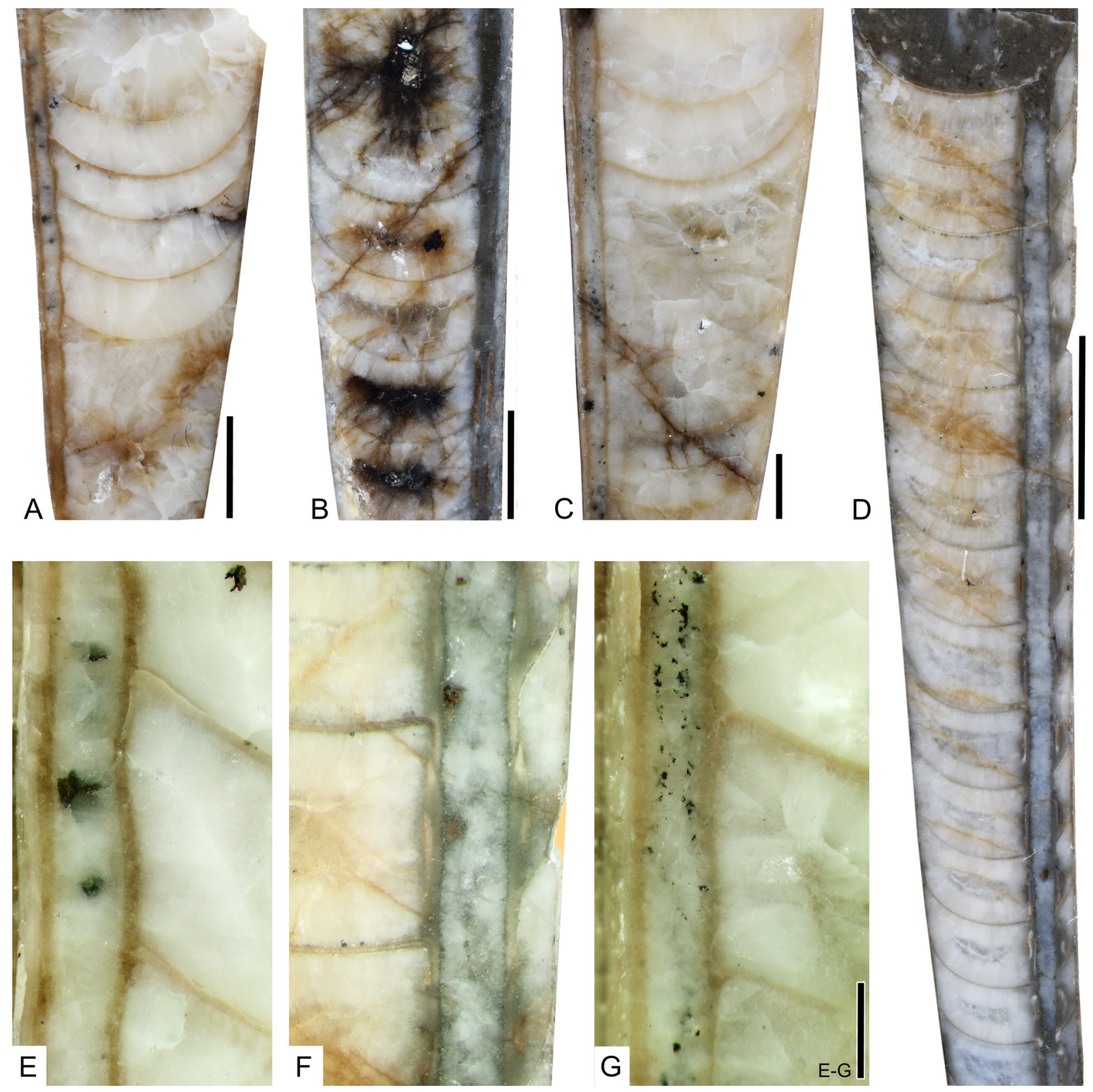

Fig. 23. Median sections of phragmocones of Svalbardoceras gen. nov., from Olenidsletta Member, Floian, Ordovician, Profilstranda section, Ny Friesland, Spitsbergen. A, C, E, G. Svalbardoceras sterna gen. et sp. nov., from bed PO 7.5. A, E. Specimen FMNH-P30371. B, D, F. Svalbardoceras skua gen. et sp. nov., from bed PO 123.3. B. Specimen FMNH-P30275. C, G. Specimen FMNH-P30368, holotype. D, F. Specimen FMNH-P30471, oblique sagittal section through siphuncle, distance from conch margin is cutting effect. Scale bars: $A-D=5 \mathrm{~mm} ; \mathrm{E}-\mathrm{G}=1 \mathrm{~mm}$. 
orthochoanitic to hemichoanitic; siphuncular segments tubular to slightly expanded; connecting rings thin and homogeneous (adopted from Aubrechtová 2015).

\section{Remarks}

One of the diagnostic characters of Bactroceras, given in Aubrechtová (2015), is the absence of endosiphuncular deposits. This is a slight emendation of previous diagnoses of the genus by Aubrechtová (2015) adopted by King \& Evans (2019). In Kröger \& Evans (2011) the diagnosis reads "endosiphuncular deposits unknown" and in the original diagnosis of Bactroceras of Holm (1898) no statement about endosiphuncular deposits is given.

With the discovery of endosiphuncular deposits, herein, in a species which is very similar to the type species of Bactroceras, the subtle emendation by Aubrechtová (2015) becomes crucial. Accepting it would require the erection of a new genus, which would be identical to Bactroceras, but which would differ in the known presence of endosiphuncular deposits. Alternatively, the original genus diagnosis could be revived again, so that potentially species with endosiphuncular deposits can be included. Here the latter solution of the problem is suggested, because it is very difficult, and often impossible, to definitively make a statement on the absence of endosiphuncular deposits. A sufficiently large sample of apical fragments to contain individuals that grew large enough to have developed endosiphuncular deposits is required. This character (the absence of deposits) would render the genus very difficult to practically apply to species, or it would increase the risk that it becomes a wastebasket taxon for inadequately known fragments (e.g., Ormoceras Stokes, 1840). And more generally, the absence of a feature, such as endosiphuncular deposits, whose presence theoretically cannot be ruled out, is a diagnostic character that can be falsified, even if the chances of falsification are low. Therefore, the original diagnosis of Holm (1898) is here taken as a reference. Thoraloceras Kröger \& Evans, 2011, which is a troedsonellid with a marginal siphuncle with endosiphocones, similar to Bactroceras, and which occurs in Tremadocian strata of the Montagne Noir, differs from the latter mainly in having a wider siphuncle $(1 / 4$ of the conch cross section) and a smooth conch surface.

Bactroceras boliviensis Aubrechtová, 2015

Figs 12E, H, J, 13C, 24-27, 28A-B, 29B

Bactroceras boliviensis Aubrechtová, 2015: 206-207, fig. 6a-d, g.

Bactroceras aff. avus Holm - Marek et al. 2000: 56.

Bactroceras angustisiphonatum (Rüdiger) - Evans 2005: 27-31, pl. 3 figs 12-13, 15, 17-18, pl. 4 figs 2, 16.
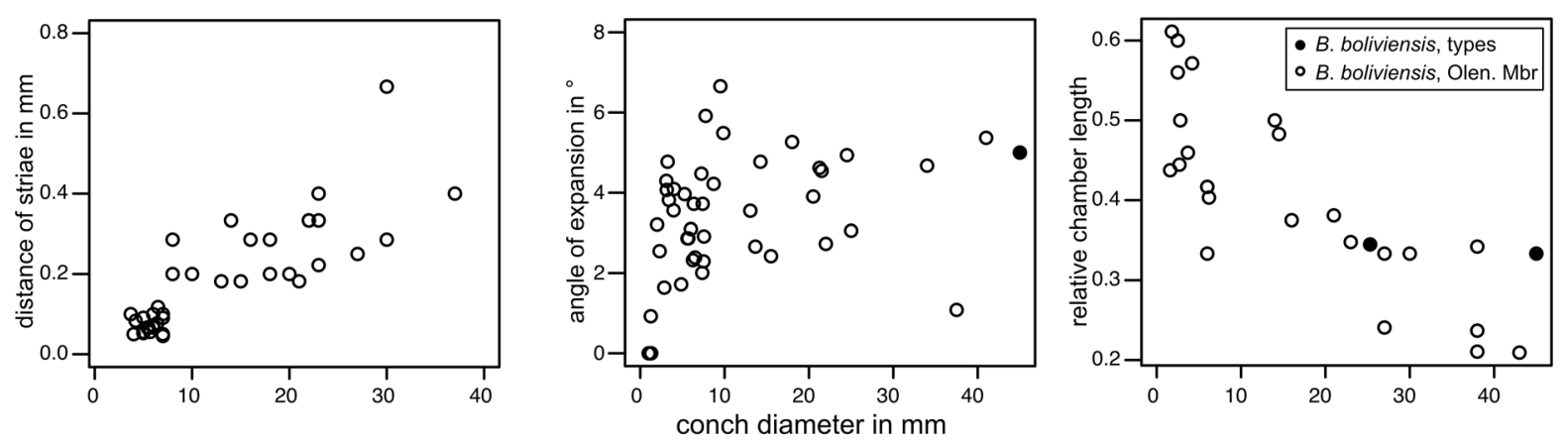

Fig. 24. Diagrams of spacing of ornamentation, angle of expansion, and relative chamber length of Bactroceras boliviensis Aubrechtová, 2015 from the Olenidsletta Member (Olen. Mbr), Floian, Ordovician, Profilstranda section, Ny Friesland, Spitsbergen. Data of type specimens from Aubrechtová (2015). See Supp. file 1 for details of measurements. 


\section{Diagnosis}

Bactroceras with a large shell diameter $(>45 \mathrm{~mm})$, ornamented with transverse striae, and with concavity of septa of $30 \%$; siphuncle tubular, marginal; diameter of siphuncle $1 / 8$ to $1 / 7$ of the corresponding conch diameter; connecting ring very thin (after Aubrechtová 2015).

\section{Material examined}

Sixty-eight specimens (see Supp. file 1 for list of specimens); one from bed PO 7, two from bed PO 7.5, two from bed PO 123.3, and 62 from bed PO 131, $4 \mathrm{~m}, 4.5 \mathrm{~m}, 120.3 \mathrm{~m}$, and $128 \mathrm{~m}$ above base of Olenidsletta Member, V1-V2 trilobite zone, Blackhillsian, Floian. An additional number of 15 microscopic specimens from bed PO 131.

\section{Description}

The conchs are straight and expand gradually with a low angle of expansion, ca $4^{\circ}$ (mean $3.7^{\circ} ; 1^{\text {st }}-3^{\text {rd }}$ quantile: $2.7-4.5 ; \mathrm{n}=37$ ) (Fig. 24). The conch cross section is invariantly circular. The largest specimen in the sample is a fragmentary body chamber with a maximum diameter of ca $48 \mathrm{~mm}$ and a length of
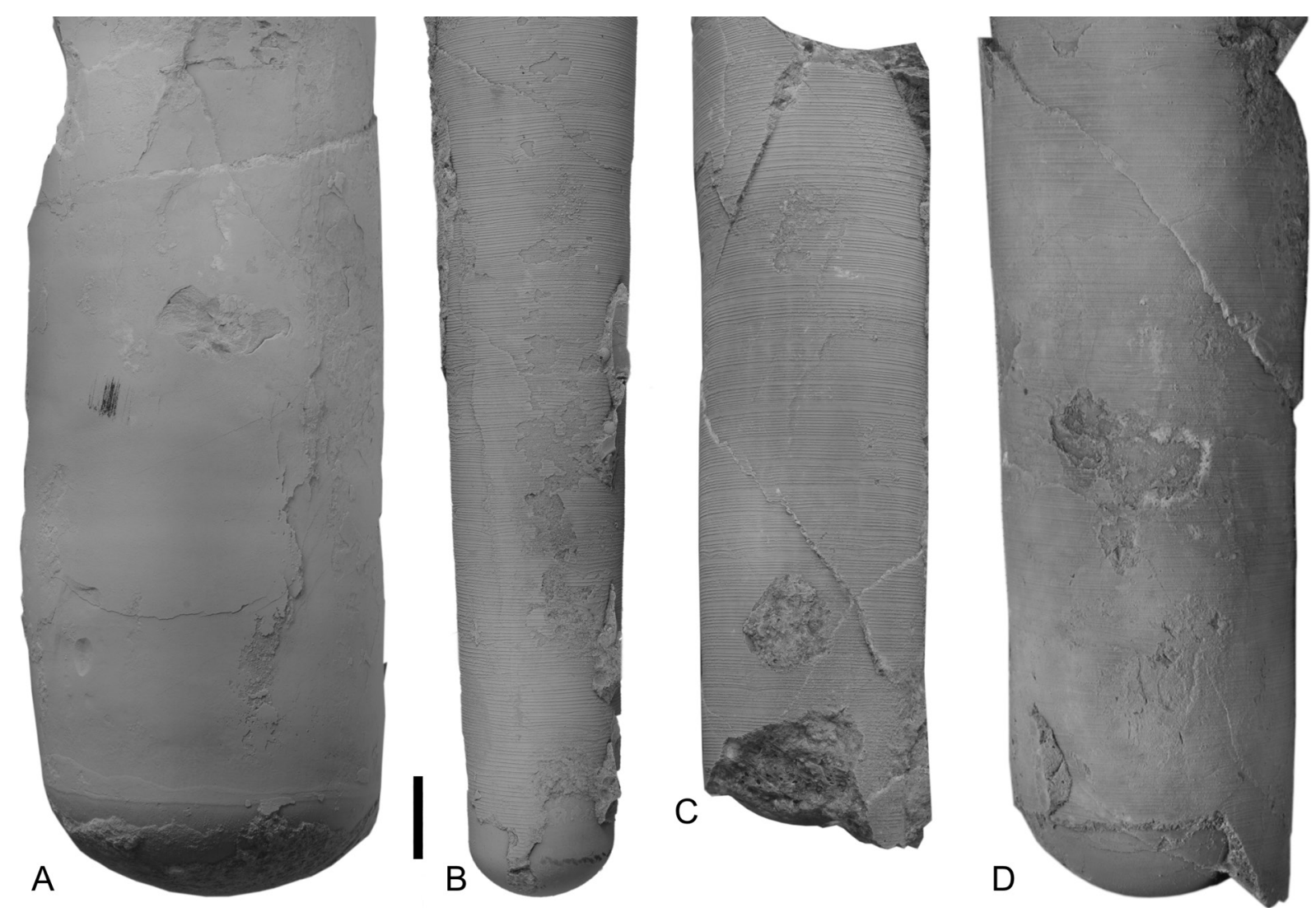

Fig. 25. Bactroceras boliviensis Aubrechtová, 2015, from bed PO 131, from the Olenidsletta Member, Floian, Ordovician, Profilstranda section, Ny Friesland, Spitsbergen. A. Specimen FMNH-P30430, lateral view of body chamber with dorsomyarian muscle impression at base ventral, prosiphuncular side toward the left. B. Specimen FMNH-P30231, view of ventral, prosiphuncular side. C. Specimen FMNH-P30248, lateral view of specimen with partly cyclic spacing of ornamentation; ventral, prosiphuncular side toward the right. D. Specimen FMNH-P30215, with fine transverse ornamentation; ventral, prosiphuncular side toward the right. Scale bar $=10 \mathrm{~mm}$ for all figures. 
$92 \mathrm{~mm}$ (specimen FMNH-P30179). At the base of the body chamber, where the diameter is $38 \mathrm{~mm}$, a narrow paired dorsomyarian muscle scar is preserved (Fig. 25A).

The conch surface is ornamented with striae, which are directly transverse and run parallel to the sutures (Figs 13C, 25B-D). The striae are very slightly shifted toward the apex at the prosiphuncular side, forming a very shallow ventral sinus. The striae have partly an imbricated profile in well preserved specimens and are rounded in less well preserved and smaller specimens. The spacing of the striae increases with growth in relation to the conch diameter (Fig. 24), reaching densities between 1-20 lirae per one millimeter.

The relative chamber length varies between 0.6 in the smallest preserved growth stages with diameters of less than $5 \mathrm{~mm}$ and 0.2 in the largest specimens with diameters $>35 \mathrm{~mm}$. The diameter of the septal foramen is ca $1 / 6$ of corresponding conch cross section (mean $\mathrm{rSD}=0.17 ; 1^{\text {st }}-3^{\text {rd }}$ quantile: $0.15-0.19$; $\mathrm{n}=55$ ) (Fig. 26). The rSD decreases with conch diameter toward 0.15 at a maximum conch diameter of $43 \mathrm{~mm}$ (Fig. 26). The siphuncle is eccentric, positioned between the center of the conch and the conch margin in early growth stages with conch cross section diameters $<6 \mathrm{~mm}$, and it is nearly marginal in later growth stages (Fig. 26). The septal necks are orthochoanitic and the siphuncular segments are tubular and have a thin connecting ring (Fig. 27).

The siphuncles of specimen FMNH-P30215 from bed PO 131, and specimens FMNH-P30243 and FMNH-P30259 from bed PO 7.5 (Figs 27A-D, 28A-B), contain an irregular conical continuous endosiphuncular lining, which adapically fills the entire siphuncle but thins out adorally within a length of ca $20-30 \mathrm{~mm}$ at conch diameters of up to $38 \mathrm{~mm}$.

The conch apex consists of a nearly spherical protoconch with a mean diameter of $1.1 \mathrm{~mm}\left(1^{\mathrm{st}}-3^{\text {rd }}\right.$ quantile: $1.1-1.2 ; \mathrm{n}=15)$ and a mean length of $1 \mathrm{~mm}\left(1^{\text {st }}-3^{\text {rd }}\right.$ quantile: $\left.1.0-1.1 ; \mathrm{n}=15\right)$, which is distinguished from a shaft by a shallow, often very indistinct constriction (Figs 12J, 29B). The spherical initial part is smooth, without a cicatrix (Fig. 12H), and the following ca 5-10 mm of the initial part of the conch is nearly smooth. In some well-preserved specimens a faint, narrow, transverse ornamentation is visible, which becomes more pronounced during growth. The shaft and the following ca $5-10 \mathrm{~mm}$ are almost straight and have a very low angle of expansion or are tubular. At a distance of $25 \mathrm{~mm}$ from the apical tip the conch is only $2.7 \mathrm{~mm}$ wide in specimen FMNH-P30165. The caecum is elongated; in specimen FMNH-P30176 it is ca $0.4 \mathrm{~mm}$ long and $0.3 \mathrm{~mm}$ wide, directly marginal and reaches only through the adoral half of the initial chamber, which is $0.7 \mathrm{~mm}$ long. Septal crowing occurs in specimen

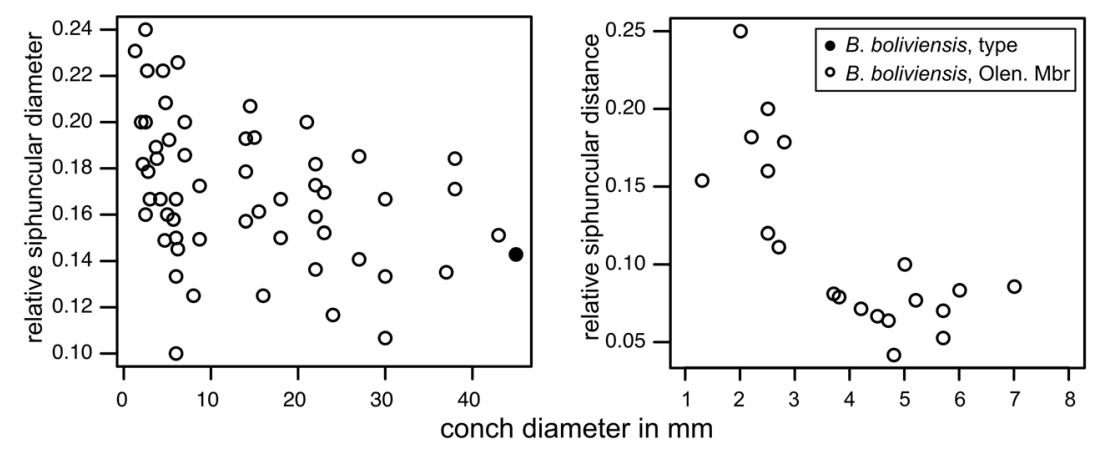

Fig. 26. Diagrams of relative siphuncular diameter and relative siphuncular distance of Bactroceras boliviensis Aubrechtová, 2015, from the Olenidsletta Member (Olen. Mbr), Floian, Ordovician, Profilstranda section, Ny Friesland, Spitsbergen. Data of type specimen from Aubrechtová (2015). See Supp. file 1 for details of measurements. 
FMNH-P30176 between the second to fourth septum with a distance between 0.4 and $0.5 \mathrm{~mm}$, and the subsequent four chambers have a length of 0.7-0.9 mm (Fig. 29B).

\section{Remarks}

The assignment of the specimens described above to B. boliviensis is justified herein by the combination of the distinctively pronounced transverse ornamentation, a relatively wide siphuncle, and a relatively
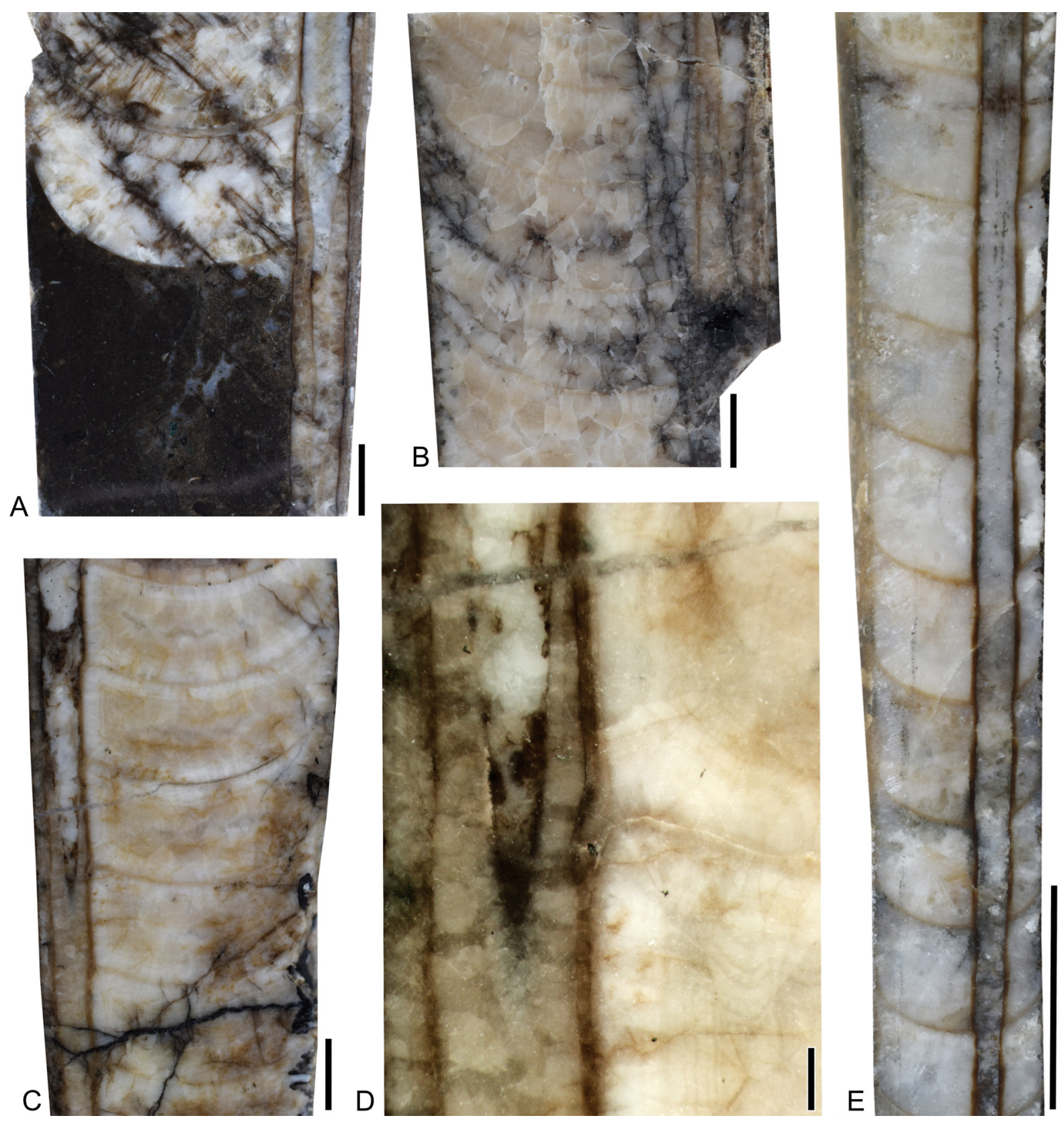

Fig. 27. Median sections of phragmocones of Bactroceras boliviensis Aubrechtová, 2015, from the Olenidsletta Member, Floian, Ordovician, Profilstranda section, Ny Friesland, Spitsbergen. Note conical endisiphuncular lining in A-D. A. Specimen FMNH-P30215, from bed PO 131. B. Specimen FMNH-P30259, from bed PO 7.5. C-D. Specimen FMNH-P30243, from bed PO 7.5. E. Specimen FMNH-P30383, from bed PO 131. Scale bars: A-C, $E=5 \mathrm{~mm}$; $\mathrm{D}=1 \mathrm{~mm}$. 
large adult size. The relative siphuncular diameter of the Olenidsletta Member specimens is on average slightly wider than that of the holotype and syntype of B. boliviensis. However, the range of measurements of the two types is well within the range of our specimens (see Fig. 24).

Another species of Bactroceras with a similarly wide siphuncle $(\mathrm{rSD}=1 / 6)$ is $B$. wilsoni Flower, 1968 from the Antelope Valley Limestone, Nevada, USA, which differs, however, in lacking the distinctively striated ornamentation. The types of $B$. angustisiphonatum (Rüdiger, 1889) differ from the Bactroceras specimens of the Olenidsletta Member in having a very narrow siphuncle with an rSD of ca $1 / 12$ (Holm 1898: 9) to ${ }^{1 / 11}$ (Rüdiger 1889: 37). Additionally, the ornamentation of $B$. angustisiphonatum, as originally described by Rüdiger (1889: 37), is weak; Rüdiger (1889) referred to it as "Anwachsstreifen", i.e., growth lines (this is in contrast to his use of the term "Ringlinien", i.e., transverse striae, e.g., Rüdiger 1889: 38). The relatively weak ornamentation, with growth lines only, of the original material of B. angustisiphonatum is also explicitly mentioned in Holm (1898: 9). Bactroceras sandbergeri (Barrande, 1867) differs also in having a siphuncle with a diameter of $<0.1$ of the corresponding conch cross section (Aubrechtová 2015).

Evans (2005) described an assemblage of ca 40 specimens from the Olenidssletta Member, collected by R.A. Fortey and D.L. Bruton, under "B. angustisiphonatum (Rüdiger, 1891)" (sic!). The assemblage came from "the top of division $\mathrm{V}_{2}$ " (Evans 2005: 28), with high probability from exactly the same horizon as most of the specimens assigned to B. boliviensis herein. Bactroceras boliviensis is distinctive within the orthocones of the Olenidssletta Member and occurs in great numbers at $128 \mathrm{~m}$ above the base of the member at Profilstranda. The specimens from the Olenidssletta Member described by Evans (2005) are therefore with high probability in large part conspecific with the specimens described herein under B. boliviensis. Our measurements add to the knowledge of the variability of this assemblage, and specifically the dimensions and characters of the apical parts are almost identical (compare Evans 2005: text-fig. 8e). However, B. boliviensis co-occurs with Ethanoceras solitudines gen. et sp. nov., which differs in having a less pronounced ornamentation and a non-marginal, eccentrically positioned siphuncle throughout its entire growth. This makes the distinction between Bactroceras and Ethanoceras difficult or impossible in specimens with diameters $<6 \mathrm{~mm}$ and without well preserved outer shell or extreme

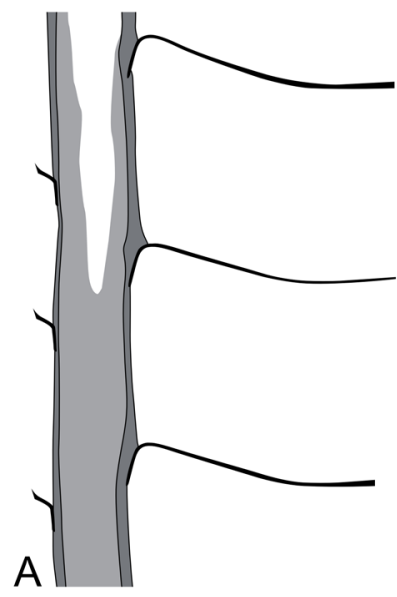

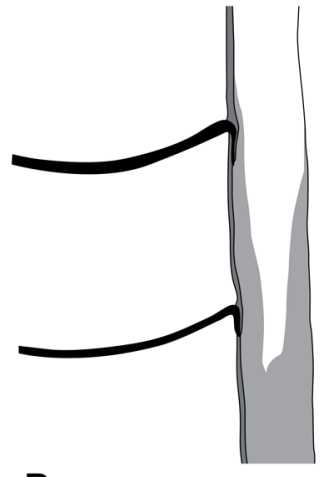

B

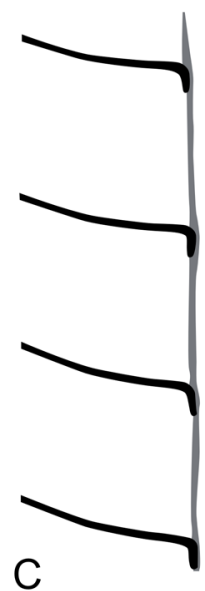

C

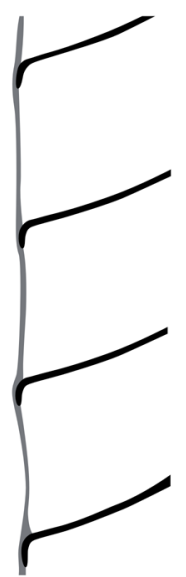

Fig. 28. Reconstruction and interpretation of details of connecting ring and septal necks. A-B. Bactroceras boliviensis Aubrechtová, 2015. A. Specimen FMNH-P30243, see Fig. 27D. B. Specimen FMNH-P30215, see Fig. 29A. C. Eosomichelinoceras borealis sp. nov., from the Olenidsletta Member, Floian, Ordovician, Profilstranda section, Ny Friesland, Spitsbergen, specimen FMNH-P30305, see Fig. 33C. Black: septal neck and septum. Dark grey: connecting ring. Light grey: endosiphuncular deposits. Without scale. 

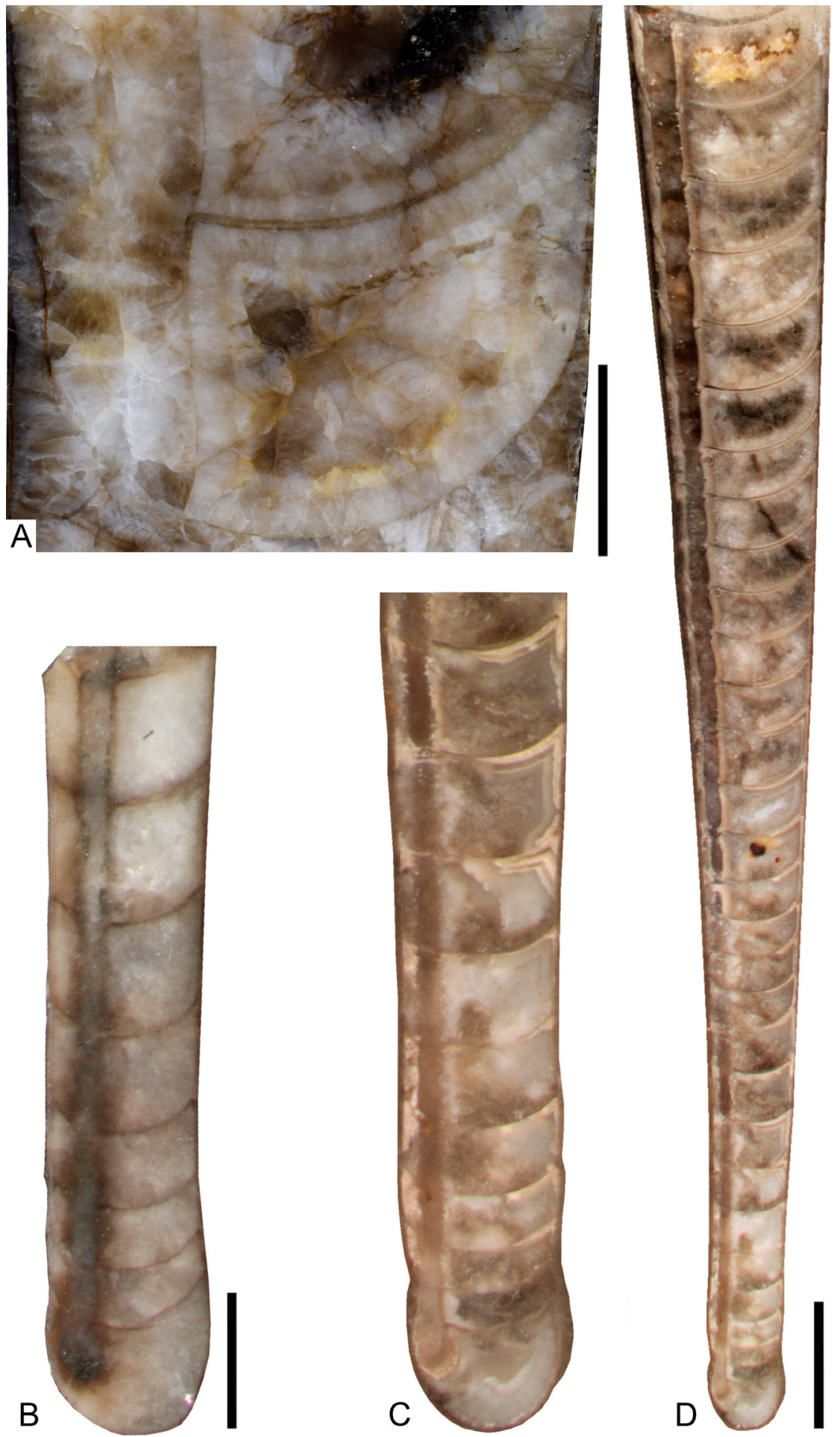

Fig. 29. Median sections of phragmocones of Bactroceras Holm, 1898. A, C-D. Bactroceras fluvii sp. nov., from Profilbekken river basin, locality PR-phosphatic. A. Specimen FMNH-P30159, with adapical siphuncular segment, taphonomically slightly distorted. B. Bactroceras boliviensis Aubrechtová, 2015, FMNH-P30176 from bed PO 131, extreme apical part. C-D. Specimen FMNH-P30177, holotype. C. Details of the protoconch. D. Apical part with transition toward juvenile growth stages; note the slightly expanded siphuncular segments. Scale bars: A $=5 \mathrm{~mm}$; $\mathrm{B}-\mathrm{C}=1 \mathrm{~mm} ; \mathrm{D}=2 \mathrm{~mm}$. 
apical parts. Therefore, we measured only specimens with a well-preserved shell surface. Our results differ slightly from the measurements of Evans (2005: text-fig. 8) in having a strictly marginal siphuncle position in B. boliviensis in specimens with diameters $>$ ca $6-7 \mathrm{~mm}$. This difference is potentially a result of unrecognized specimens of Ethanoceras solitudines gen. et sp. nov. in the sample of Evans (2005).

\section{Stratigraphic and geographic range}

The types and previously only known specimens of $B$. boliviensis are from the Pircancha Formation, Bolivia, Baltograptus minutus graptolite zone, which is time equivalent to the lower part of the Didymograptus bifidus graptolite zone (see Gutiérrez-Marco \& Martin 2016). The D. bifidus graptolite zone reaches into the upper part of the $\mathrm{V}_{1}$ division of the Olenidsletta Member (Cooper \& Fortey 1982). The specimens described herein are from $\mathrm{V}_{1}-\mathrm{V}_{2}$ trilobite zones; hence the species is known from the Blackhillsian, late Floian of Bolivia and Spitsbergen.

$$
\begin{gathered}
\text { Bactroceras fluvii sp. nov. } \\
\text { urn:Isid:zoobank.org:act:A0C49BC7-0551-4BD0-ABC5-77A446BBF5D1 } \\
\text { Figs 12D, 29A, C-D, 30 }
\end{gathered}
$$

\section{Diagnosis}

Bactroceras with smooth shell or very faint transverse ornamentation; angle of expansion relatively low, ca $5^{\circ}$; siphuncle slightly expanded within chambers, marginal; diameter of siphuncle ca $1 / 5$ of the corresponding conch diameter during early growth stages, increasing during ontogeny.

\section{Etymology}

From the Latin 'fluvius', 'river', referring to the type locality of this species.

\section{Type material}

\section{Holotype}

Specimen FMNH-P30177.

\section{Paratypes}

One additional specimen from type locality and horizon and 18 specimens from Profilbekken river basin, locality PR-phosphatic, adjacent to Hinlopenstretet, Spitsbergen, uppermost Olenidsletta Member, V3 trilobite zone, Dapingian.

\section{Type locality and horizon}

From Profilstranda section, adjacent to Hinlopenstretet, Spitsbergen, topmost exposed layer ca 153 meters above the base of the Olenidsletta Member, V3 trilobite zone, Dapingian.

\section{Description}

The holotype is an apical part of a phragmocone with a length of $32 \mathrm{~mm}$, with a maximum measurable diameter of $3.3 \mathrm{~mm}$, and a subspherical protoconch with a diameter $1.1 \mathrm{~mm}$ (Fig. 29C-D). The conch surface is apparently smooth and the conch cross section circular. The protonconch is clearly distinguished from the subsequent shaft by a constriction with a diameter of $0.9 \mathrm{~mm}$ at a distance of ca $1 \mathrm{~mm}$ from the apical end of the shell. The conch is weakly curved with a concave curvature at the ventral (prosiphuncular) side and grows within the first $2 \mathrm{~mm}$ only to a conch diameter of $1.1 \mathrm{~mm}$. A diameter of $1.3 \mathrm{~mm}$ is reached at a distance $5 \mathrm{~mm}$ from the apical end of the shell. The siphuncle is marginal throughout the entire length of the holotype, it is tubular to slightly expanded within the chambers and has a diameter of $0.6 \mathrm{~mm}$ at the adoral end of the specimen $(\mathrm{rSD}=0.18)$. The septal necks are short orthochoanitic with a length of ca $1 / 3$ of the length of the siphuncular segment. The chamber 
spacing varies greatly depending on the growth stage. The first chamber has a length of $0.6 \mathrm{~mm}$, the next three chambers, which are roughly at the position of the constriction and initial shaft, are very short, with lengths of $0.25-0.35 \mathrm{~mm}$, and the subsequent chambers have a length of $0.5-0.7 \mathrm{~mm}$. At a conch diameter of $3.3 \mathrm{~mm}$ the chamber length is $1.2 \mathrm{~mm}(\mathrm{rCL}=0.37)$ and the septum curvature is $0.7 \mathrm{~mm}$ deep. The caecum is slightly elongated and reaches through the adoral half of the initial chamber with a length of $0.35 \mathrm{~mm}$ and a maximum diameter of $0.3 \mathrm{~mm}$. The septal perforation of the first septum has a diameter of $0.2 \mathrm{~mm}$.

In specimens FMNH-P30168 and FMNH-P30177 (holotype) the sutures of the initial growth stages are well preserved. They run directly transverse and form a shallow ventral lobe in the vicinity of the ventral siphuncle (Fig. 12D).

Only two specimens with diameters $>>3 \mathrm{~mm}$ are available. Specimen FMNH-P30200 is a natural sagittal section through a phragmocone with a diameter of 2.2-7.5 mm and a length of $34 \mathrm{~mm}$ (angle of expansion $\left.9^{\circ}\right)$, a siphuncular diameter of $1.5 \mathrm{~mm}(\mathrm{rSD}=0.21)$ and a chamber height of $3.8 \mathrm{~mm}(\mathrm{rCL}=$ $0.51)$ at the adoral end of the fragment.

The largest specimen (FMNH-P30167) is a straight, ca $97 \mathrm{~mm}$ long fragment of a phragmocone with partly imploded septa with circular conch cross section, a smooth conch surface and a diameter of 12-19 mm (angle of expansion 4.4 ${ }^{\circ}$ ) (Fig. 29A). The specimen has a marginal siphuncle with a $4.5 \mathrm{~mm}$ wide siphuncle at a corresponding conch cross section of $14.5 \mathrm{~mm}(\mathrm{rSD}=0.31)$ and a septal distance of $7.5 \mathrm{~mm}$ at the same position on the conch $(\mathrm{rCL}=0.51)$. The septal necks are $1.7 \mathrm{~mm}$ long where the siphuncular segment is $7.5 \mathrm{~mm}$ long, and the septa have a curvature of $5 \mathrm{~mm}$ where the diameter of the septa is $14 \mathrm{~mm}$.

\section{Remarks}

The sample of specimens of Bactroceras fluvii sp. nov. consists of 18 microscopic specimens with diameters $<3 \mathrm{~mm}$ or slightly larger, one specimen with a maximum diameter of $7.5 \mathrm{~mm}$ and a single specimen with conch diameters of $12-19 \mathrm{~mm}$. The large specimen differs from the microscopic specimens in its large relative siphuncle size $(\mathrm{rSD}=0.31)$ and in its deep septal curvature (Fig. 30). Because no transitional growth stages are known, the combination of the two size classes and the assumption of large ontogenetic changes is somewhat speculative. However, because a similar increasing rSD is known from Bactroceras mourgesi Kröger \& Evans, 2011, which also has a slightly expanded siphuncle, the assumption of a similar change in the phragmocone dimensions in B. fluvii gen. et sp. nov. is not unrealistic.
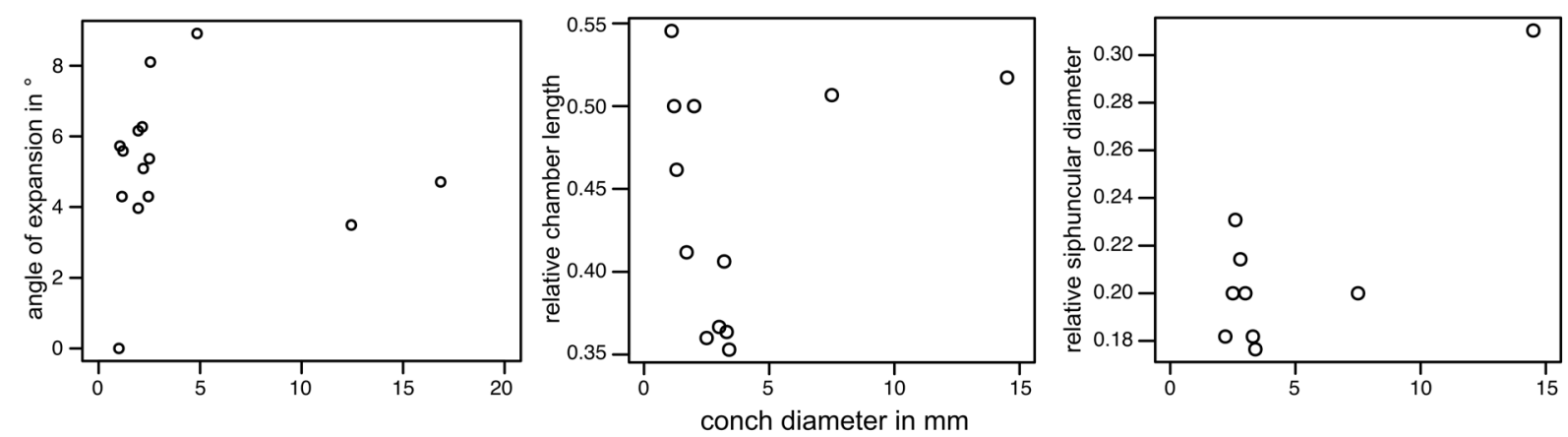

Fig. 30. Diagrams of relative angle of expansion, relative chamber length, and relative siphuncular diameter of Bactroceras fluvii sp. nov., uppermost Olenidsletta Member, V3 trilobite zone, Dapingian, adjacent to Hinlopenstretet, Ny Friesland, Spitsbergen. See Supp. file 1 for details of measurements. 


\section{Comparison}

This new species of Bactroceras is similar to B. mourgesi, from the Tremadocian of the Montagne Noire, in having a slightly expanded siphuncle with a diameter of ca 0.2 of the conch diameter and in having slightly curved early growth stages. Bactroceras fluvii gen. et sp. nov. differs from B. mourgesi in its concave curvature on the prosiphuncluar side in early growth stages and in having a lower angle of expansion. Bactroceras boliviensis differs in its distinctively striated conch and in being nearly tubular and straight immediately adoral of the protoconch. Additionally, the siphuncle of B. boliviensis is nearly tubular. Other species of Bactroceras have a narrower siphuncle (compare Aubrechtová 2015).

Order Dissidocerida Zhuravleva, 1964

Family Cyptendoceratidae Zhuravleva, 1994

\section{Emended diagnosis}

Straight longicones with siphuncle marginal or submarginal, relatively wide with concave or convexoconcave segments; septal necks short, loxochoanitic to orthochoanitic; connecting rings relatively thick; endosiphuncular deposits form thick ventral rod which merges adapically into a complete siphuncular filling, diaphragms unknown; cameral deposits epi- and hyposeptal, concentrated on prosiphuncular side.

\section{Remarks}

The diagnosis of the Cyptendoceratidae largely follows Zhuravleva (1994), but is more restricted following the emendation of the Baltoceratidae by Kröger et al. (2007), in which rod-bearing smooth longicones with tubular siphuncles, such as Rangeroceras Hook \& Flower, 1977, Rhabdiferoceras Flower, 1964 and Veneficoceras Hook \& Flower, 1977, are now included within the Baltoceratidae. The family now contains rod-bearing smooth and annulated forms with concave siphuncular segments and includes four genera: Cyptendoceras Ulrich \& Foerste, 1936, Amsleroceras Hook \& Flower, 1977, Catoraphiceras Ulrich \& Foerste, 1936, and Hemichoanella Teichert \& Glenister, 1954.

Genus Cyptendoceras Ulrich \& Foerste, 1936

\section{Type species}

Cyptendoceras ruedemanni Ulrich \& Foerste, 1936; from Fort Cassin Formation, Floian Stage, from near Fort Cassin, Vermont, USA; by original designation.

\section{Diagnosis}

Straight, slender, depressed conchs with short camerae; sutures with ventral lobe, in some forms also dorsal lobe; siphuncle ventral with tubular or faintly concave segments; short septal necks; endosiphuncular rod; cameral deposits adjacent to siphuncle are present (adopted from Flower 1964).

\section{Cyptendoceras sp. A}

Fig. $9 \mathrm{~F}-\mathrm{G}$

\section{Material examined}

Specimen FMNH-P30426, from Profilstranda section, adjacent to Hinlopenstretet, Spitsbergen, bed PO 07, 4 m above base of Olenidsletta Member, V1a trilobite zone, Blackhillsian, Floian. 


\section{Description}

The specimen is a fragment of a slightly crushed $30 \mathrm{~mm}$ long portion of a body chamber with the last septum preserved. The conch is smooth, straight and slender and has an elliptically depressed cross section with a height of $18 \mathrm{~mm}$ and a width of $22 \mathrm{~mm}(\mathrm{rW}=1.22)$. The preserved septum forms a suture that is slightly oblique across the flanks of the conch shifted toward the aperture at the antisiphuncular side of the conch; it forms shallow lateral saddles, is almost transverse dorsally, and forms a deep, broad u-shaped ventral lobe. The siphuncle is marginally positioned and elliptically depressed with a septal perforation $8 \mathrm{~mm}$ in height and $9 \mathrm{~mm}$ in width $(\mathrm{rSD}=0.4)$. No details of the septal necks or the connecting ring are preserved.

\section{Remarks}

The specimen is assigned to Cyptendoceras because of the presence of the characteristic u-shaped ventral lobe. However, neither the septal spacing, nor the details of the septal necks and connecting ring are known, which precludes a species level determination of the specimen.

\section{Cyptendoceras sp. B}

Figs $12 \mathrm{~A}, 31 \mathrm{C}$

\section{Material examined}

Specimens FMNH-P30166 and FMNH-P30472, from Profilbekken river basin, locality PR-phosphatic, adjacent to Hinlopenstretet, Spitsbergen, uppermost Olenidsletta Member, V3 trilobite zone, Dapingian.

\section{Description}

The larger specimen, FMNH-P30166, is a fragment of a phragmocone with smooth shell, a circular or slightly compressed conch cross section with diameters $31-38 \mathrm{~mm}$ and a length of $82 \mathrm{~mm}$ (angle of expansion ca $5^{\circ}$ ). The siphuncle is marginally positioned, is subcircular or slightly depressed in cross section with a height of $11.5 \mathrm{~mm}$, where the conch height is $36 \mathrm{~mm}(\mathrm{rSD}=0.32)$. The septa are imploded and crushed. Where visible they are $5 \mathrm{~mm}$ apart at a conch height of $34 \mathrm{~mm}(\mathrm{rCL}=0.15)$ with the sutures forming a distinct ventral lobe. The septal necks are loxochoanitic with a length of $1.2-1.7 \mathrm{~mm}$ where the siphuncular segment is $5 \mathrm{~mm}$ long $(0.24-0.34$ of chamber length). The connecting ring is slightly concave and poorly preserved, making an estimation of its thickness impossible (Fig. 31C).

The second specimen, FMNH-P30472 (Fig. 12A), is a $20 \mathrm{~mm}$ long apical portion of a phragmocone with a smooth outer surface and a slightly compressed conch cross section. This fragment is slightly curved with the siphuncle marginally positioned at the concave side of conch curvature. The siphuncle is empty and apparently circular in cross section, with a diameter of $1.4 \mathrm{~mm}$ where the conch height is $4 \mathrm{~mm}$. The extreme apex is cup-shaped without constriction and grows from its extreme tip toward a conch height of $1.3 \mathrm{~mm}$ within the apical $1 \mathrm{~mm}$; at a distance of $2 \mathrm{~mm}$ from the tip the conch is $1.7 \mathrm{~mm}$ high, at a distance of $5 \mathrm{~mm}$ the conch height is $2.3 \mathrm{~mm}$. The angle of expansion between $1 \mathrm{~mm}$ from tip toward the adoral end of the specimen is ca $7^{\circ}$.

\section{Remarks}

These specimens are assigned to Cyptendoceras because they combine a relatively wide marginal siphuncle and (in the larger specimen) concave segments, loxochoanitic septal necks and a ventral sutural lobe, although the preserved parts of the siphuncle are empty. Most species of Cyptendoceras have a narrower chamber spacing and a slightly depressed cross section. In C. mesleri Ulrich, Foerste, Miller \& Unklesbay, 1944 only five chambers occur in a distance similar to conch height, which is comparable to the rCL of specimen FMNH-P30166. However, neither C. mesleri nor the specimens 
described above allow for detailed comparison and the fragmentary character of the available specimens do not allow for a species level determination.

Genus Catoraphiceras Ulrich \& Foerste, 1936

\section{Type species}

Catoraphiceras lobatum Ulrich \& Foerste, 1936; probably from the Powell horizon (late Floian-early Dapingian Stage), Wells Creek basin, northeast of Erin, Tennessee, USA; by original designation.

\section{Diagnosis}

Annulated orthocones whose sutures form ventral lobes; cross section is depressed to circular; siphuncles are moderately large $(\mathrm{rSD}=0.25-0.35)$ and somewhat removed from the venter; septal necks are short; connecting rings are thin; some species develop ventral rods and cameral deposits (adopted from Hook \& Flower 1977).

\section{Remarks}

The genus was previously placed within the Protocycloceratidae.

Catoraphiceras sp.

Figs 10A, 32A, 36D

\section{Material examined}

Specimen FMNH-P30425 from Profilstranda section, adjacent to Hinlopenstretet, Spitsbergen, bed PO 131, $128 \mathrm{~m}$ above base of Olenidsletta Member, V2b trilobite zone, Blackhillsian, Floian.

\section{Description}

The specimen is a $20 \mathrm{~mm}$ long orthoconic fragment of a phragmocone with a ca $3 \mathrm{~mm}$ long basal part of the body chamber. The conch cross section is slightly elliptically depressed with a width of $9.5-10.8 \mathrm{~mm}$ and a height of $8.7-9.2 \mathrm{~mm}\left(\mathrm{rW}=1.13\right.$; angle of expansion of conch height $\left.9^{\circ}\right)$.

The ornamentation consists of widely rounded annulations that form a shallow sinus at the prosiphuncular side of the conch and have a distance of ca $3 \mathrm{~mm}$ and an amplitude of ca $0.5 \mathrm{~mm}$; the valley and ridges of the annulations are widely rounded. Fine details of the conch surface, which potentially exist, such as growth lines or striae, are not preserved. Roughly one annulation occurs per one chamber.

The chambers have a distance of 3-3.5 mm (ca three chambers occur at a distance similar to conch height, $\mathrm{rCL}=0.33$ ). The siphuncle is nearly marginal and has a diameter of 3.7 at the adapical end, and $3.9 \mathrm{~mm}$ at the adoral end ( 0.42 of conch height). The connecting ring is thick and consists of slightly concave segments. The shape and length of the septal necks is difficult to interpret because of the poor preservation of the specimen, but they appear to be short orthochoanitic. No cameral or endosiphuncular deposits occur.

\section{Remarks}

This is an annulated orthocone with a large siphuncle, larger than the range given for Catoraphiceras in the diagnosis of Hook \& Flower (1977). The assignment of the fragment to Catoraphiceras is justified because all other characters are in agreement with the diagnosis of this genus and there is no other annulated orthocone with a marginal, empty siphuncle with slightly concave segments and short septal necks. Among the species of Catoraphiceras with depressed conch cross section C. colon (White, 1875) and C. resseri Ulrich et al., 1944 are most similar to specimen FMNH-P30425; the former mainly differs 
in having an annulation of only 2 annuli per distance similar to corresponding conch height, the latter differs in having a smaller siphuncle with $\mathrm{rSD}=0.35$. The siphuncle of Catoraphiceras sp. is also larger than the siphuncle of $C$. ibexense Hook \& Flower, 1977 (rSD = 0.24). The single, relatively poorly preserved fragment available from the Olenidsletta Member, however, does not allow for the erection of a new species. The erection of a new species based on this fragmentary specimen is also not possible, because several species are known to contain endosiphuncular deposits, which may or may not exist in more apical, non-preserved, portions of specimen FMNH-P30425.

\section{Genus Hemichoanella Teichert \& Glenister, 1954}

\section{Type species}

Hemichoanella canningi Teichert \& Glenister, 1954, from Emanuel Formation, stage III (BendigonianChewtonian, see Legg 1978; Floian), Emanuel Creek, Kimberley Division, Western Australia; by original designation.

\section{Diagnosis}

Orthoconic longicones with circular conch cross section; sutures with deep, narrow siphonal lobe; siphuncle marginal, nearly tubular with $\mathrm{rSD} \approx 0.3$; septal necks hemichoanitic, connecting ring thick (compiled from Teichert \& Glenister 1954 and Furnish \& Glenister 1964).

\section{Remarks}

The genus is provisionally placed within the Cyptendoceratidae because of the presence of a relatively wide siphuncle with relatively long septal necks and concave, relatively thick connecting rings (see additional remarks below in chapter Cladistic Analysis).
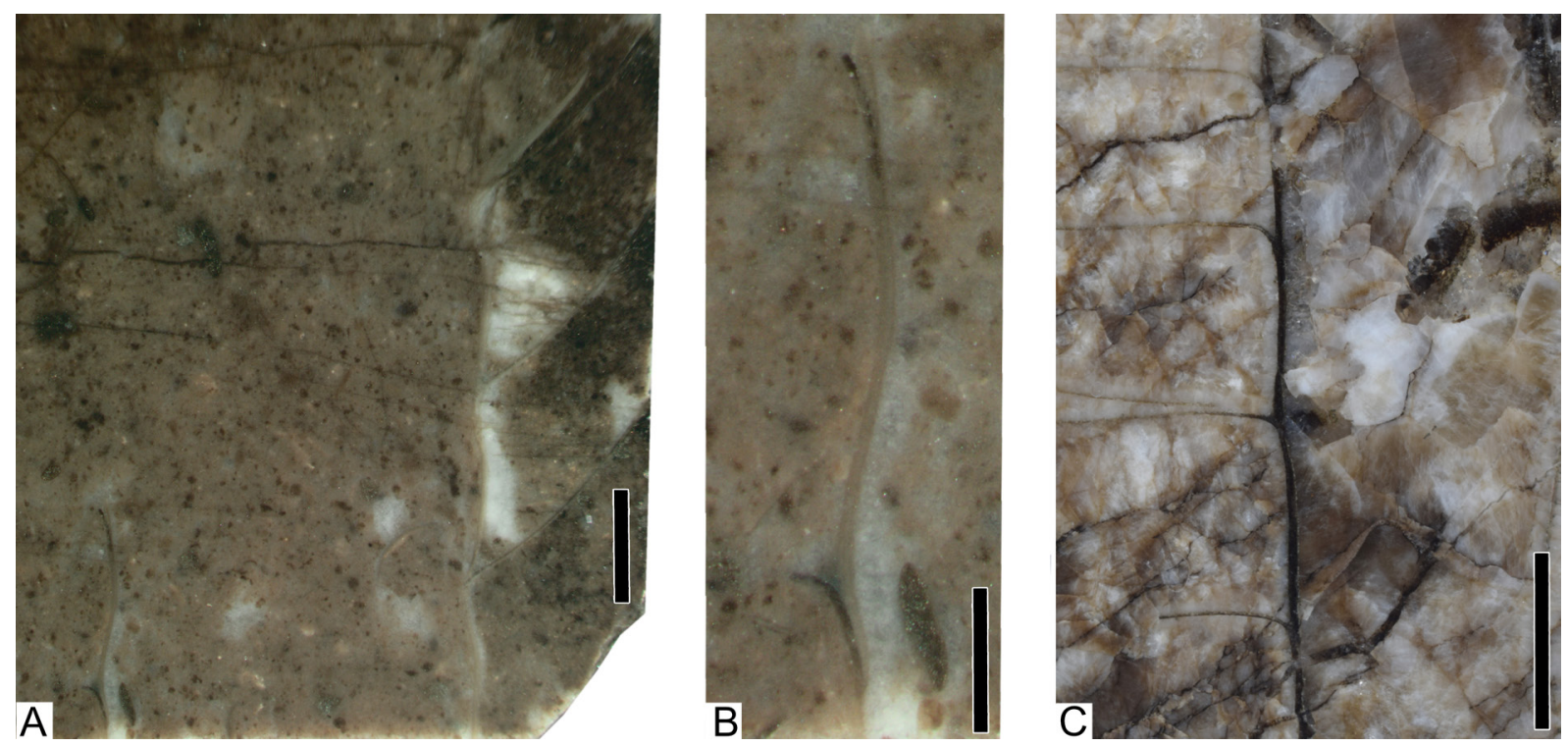

Fig. 31. Median section of details of septal necks and siphuncle of cyptendoceratids from Olenidsletta Member, adjacent to Hinlopenstretet, Spitsbergen. A-B. Cyptendoceratid gen. et sp. indet., FMNH-P30431 from bed PO 131, Floian, Ordovician, Profilstranda section, Ny Friesland, Spitsbergen. Dorsal side directed toward left. A. General view of the siphuncle. Scale bar $=2 \mathrm{~mm}$. B. Details of dorsal side of connecting ring. Scale bar $=1 \mathrm{~mm}$. C. Cyptendoceras sp. B, FMNH-P30166 from Profilbekken river basin, locality PR-phosphatic, uppermost Olenidsletta Member, V3 trilobite zone, Dapingian. Scale bar $=5 \mathrm{~mm}$. 
Hemicoanella occulta sp. nov. urn:lsid:zoobank.org:act:F8F91097-8EF4-454F-8317-F4AA1A270616

Figs $32 \mathrm{C}, 33 \mathrm{~A}-\mathrm{B}$

\section{Diagnosis}

Hemichoanella with ca three directly transverse annulations at distance similar to conch diameter and ornamented additionally with finely transverse striae; conch cross section circular; angle of expansion ca $5^{\circ}$; relatively wide marginal siphuncle with $\mathrm{rSD}$ of 0.36 ; septal necks hemichoanitic.

\section{Etymology}

From 'hidden', in Latin 'occultus', because of its Catoraphiceras-like external morphology.

\section{Type material}

\section{Holotype}

Specimen FMNH-P30420; by monotypy.

\section{Type locality and horizon}

From Profilstranda section, adjacent Hinlopenstretet, Ny Friesland, Spitsbergen; bed PO 131, $128 \mathrm{~m}$ above base of Olenidsletta Member, V2b trilobite zone, Blackhillsian, Floian.

\section{Description}

The holotype is a ca $17 \mathrm{~mm}$ long fragment of a phragmocone with a slightly compressed or circular conch cross section with a conch height of 7-8.4 mm (angle of expansion ca $5^{\circ}$ ). The conch is annulated with ca three directly transverse annulations at a distance similar to the corresponding conch cross section. Additionally, it is ornamented with ca 10 fine striae that run parallel to the annuli. The sutures are directly transverse at the flanks and at the antisiphuncular side and are not exposed at the prosiphuncular

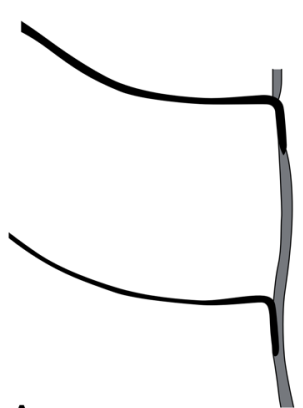

A

Fig. 32. Reconstruction and interpretation of details of connecting ring and septal necks in orthoconic cephalopods from the Olenidsletta Member, Floian, Ordovician, Profilstranda section, Ny Friesland, Spitsbergen. A. Catoraphiceras sp., FMNH-P30425, dorsal side of the connecting ring, see Fig. 10A. B. Cyptendoceratid gen. et sp. indet., FMNH-P30431, see Fig. 31B. C. Hemichoanella occulta sp. nov., FMNH-P30420, from bed PO 131, dorsal side of the connecting ring, see Fig. 36B. Black: septal neck and septum. Dark grey: connecting ring. Without scale. 
side. The chambers have a distance of ca 2.1-2.5 mm (3-4 chambers per corresponding conch cross section). The septal position does not correspond with the position of the annuli, some septa occur in the valleys, others in the rings of the annuli. The siphuncle is marginal and relatively large with a diameter of ca $3 \mathrm{~mm}$ at the adoral end of the specimen $(\mathrm{rSD}=0.36)$. The connecting ring is not preserved. The septal necks are hemichoanitic, $0.6-1 \mathrm{~mm}$ long.

\section{Remarks}

The internal characters of this species are similar to those of $H$. canningi Teichert \& Glenister, 1954, hitherto the only known species of Hemichoanella, which, however, has a smooth shell. Externally H. occulta sp. nov. is similar to species of Catoraphiceras, which differ in having shorter, orthochoanitic septal necks. Notocycloceras yurabiense Teichert \& Glenister, 1954 differs in having subholochoanitic
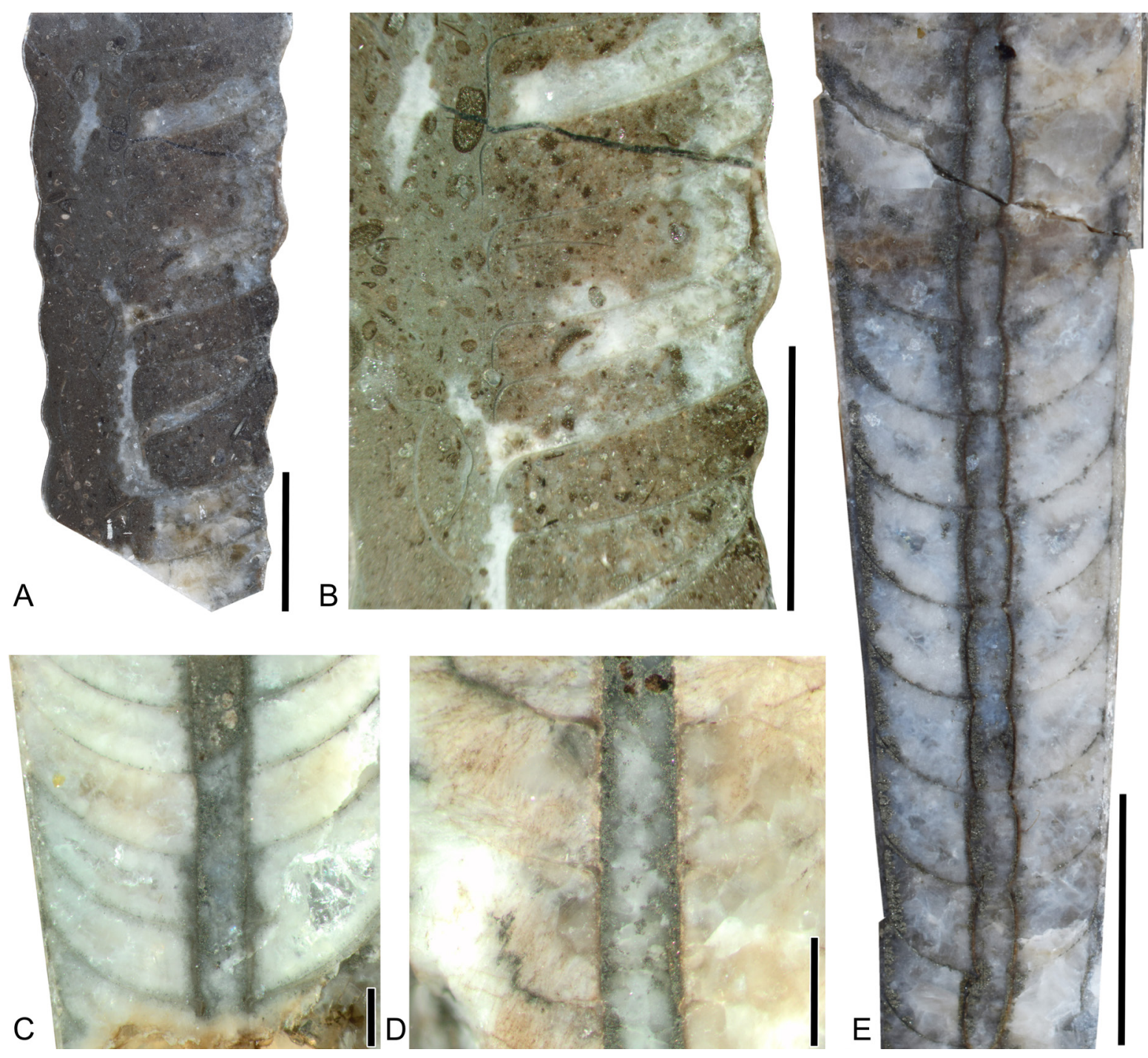

$\mathrm{E}$

Fig. 33. Median sections of phragmocones. A-B. Hemichoanella occulta sp. nov., from bed PO 131. C-E. Eosomichelinoceras borealis sp. nov., from bed PO 123.3, Olenidsletta Member, Floian, Ordovician, Profilstranda section, Ny Friesland, Spitsbergen. A-B. Specimen FMNH-P30420, holotype. C. Specimen FMNH-P30305. D. Specimen FMNH-30288. E. Specimen FMNH-30284. Scale bars: $\mathrm{A}-\mathrm{B}, \mathrm{E}=5 \mathrm{~mm} ; \mathrm{C}-\mathrm{D}=1 \mathrm{~mm}$. 
septal necks. Anthoceras warburtoni Teichert \& Glenister, 1954, A. arrowsmithense Stait \& Laurie, 1985, and Notocycloceras yurabiense Teichert \& Glenister, 1954 differ in having subholochoanitic septal necks. The siphuncle of Anthoceras xerxes (Billings, 1865) is wider ( $\mathrm{rSD}=0.43)$. The Siberian forms A. angarense Balashov, 1960 and A. bajkitense Balashov, 1960 differ in having less well pronounced annulations and a narrower septal spacing, with ca 10 chambers per distance similar to the corresponding conch diameter, and A. sibiricum Balashov, 1962 has an extremely wide siphuncle with an rSD of ca 0.5 .

Cyptendoceratid gen. et sp. indet.

Figs 9C, 31A-B, 32B

\section{Material examined}

Specimen FMNH-P30431, from Profilstranda section, adjacent to Hinlopenstretet, Spitsbergen, from bed PO 131, $128 \mathrm{~m}$ above base of Olenidsletta Member, V2b trilobite zone, Blackhillsian, Floian.

\section{Description}

The specimen is a $20 \mathrm{~mm}$ long, nearly tubular fragment of a phragmocone with a circular conch cross section, $20 \mathrm{~mm}$ in diameter. Eight chambers occur in the length of the fragment and the sutures are straight and directly transverse. The conch surface is poorly preserved but was apparently smooth. The chambers are internally imploded and crushed, preserving only a small part of the siphuncle. This is $7 \mathrm{~mm}$ in diameter and positioned between the conch center and conch margin at a distance of ca $4 \mathrm{~mm}$ from the conch margin. The septal necks are orthochoanitic and $0.7 \mathrm{~mm}$ long, where the septal distance is $3 \mathrm{~mm}$. The connecting ring is relatively thin compared to the septa and septal necks and concave on the dorsal side (the side directed toward the conch center), but convex on the ventral side.

\section{Remarks}

The combination of a large, eccentric, but not marginal siphuncle with relatively narrowly spaced septa, partly concave connecting rings and short orthochoanitic septal necks are arguments to place this specimen in the Cyptendoceratidae. A combination of ventrally expanded and dorsally contracted siphuncular segments is not known from other cyptendoceratids. However, the limited information available from this species, based on a single relatively small fragment, does not allow for a better determination.

Family Troedssonellidae Kobayashi, 1935

\section{Remarks}

In the cladistic analyses (see below), Troedssonella Kobayashi, 1935 was not recovered within the same clade as other typical troedssonellids such as Buttsoceras Ulrich \& Foerste, 1933, Tajaroceras Hook \& Flower, 1977 and Moridunoceras Evans, 2005. Therefore, the Troedssonellidae may be polyphyletic and Troedssonella is perhaps more closely related to the Orthoceratidae instead. Since Troedssonella is the type genus of the family, this would require an emendation of the family and a new family for Buttsoceras and allied genera. However, because of the unclear relationships between many Floian dissidocerids, including the Rangeroceratidae and the Polymeridae, we refrain from establishing another family here, but point out the necessity for further studies on these relationships.

Genus Buttsoceras Ulrich \& Foerste, 1936

\section{Type species}

Orthoceras? adamsi Butts, 1926, from the Odenville Limestone (late Floian-early Dapingian), near Odenville, St. Clair County, Alabama, USA; by original designation. 


\section{Diagnosis}

Slender orthocones with circular or subcircular cross section, and large subcentral siphuncles; siphuncular segments are tubular and composed of short, straight necks and thin, homogeneous connecting rings; a lamellar lining within the siphuncle thickens apically and either fills the siphuncle completely or leaves a narrow cavity dorsad of center that may be crossed by diaphragms; both hyposeptal and episeptal cameral deposits are known to develop (adopted from Hook \& Flower 1977).

Buttsoceras buldrebreenense sp. nov urn:lsid:zoobank.org:act:D6C02A7F-2CAF-44FC-A243-52AB01FCEB2C

Figs 9A-B, D-E, 11B, 34-35

\section{Diagnosis}

Smooth orthocones with elliptically compressed conch cross sections, widely spaced chambers (relative chamber length up to ca 0.6$)$; with large siphuncles $(\mathrm{rSD}=0.25)$ which are slightly expanded into the chambers and are eccentrically positioned $(\mathrm{rSP}=0.21)$; septal necks are short orthochoanitic; continuous endosiphuncular lining and episeptal deposits are present.

\section{Etymology}

From Buldrebreen, a glacier near Olenidsletta, Ny Friesland, Svalbard close to the type locality of the specimen.

\section{Type material}

\section{Holotype}

Specimen FMNH-P30421.

\section{Paratypes}

Four specimens (FMNH-P30422, P30423, P30428, P30430) from type locality and horizon.

\section{Type locality and horizon}

Profilstranda section, adjacent Hinlopenstretet, Spitsbergen, from bed PO 131, $128 \mathrm{~m}$ above base of Olenidsletta Member, V2b trilobite zone, Blackhillsian, Floian.

\section{Description}

The holotype, FMNH-P30421, is a $44 \mathrm{~mm}$ long, nearly straight fragment of a phragmocone with a smooth conch surface and a compressed conch with a height of $16.7-17.3 \mathrm{~mm}$ and a width of 14.8 $16 \mathrm{~mm}\left(\mathrm{rW} \approx 0.9\right.$, angle of expansion of conch height $2^{\circ}$ ) (Fig. 9E). The angle of expansion is $5^{\circ}$ in specimen FMNH-P30430, which has a conch height of 21-23 mm.

The conch surface is almost smooth with faint, irregularly spaced growth lines which may form striae with a distance between 1 and $2 \mathrm{~mm}$ in the holotype. The growth bands or growth lines are obliquely transverse, shifted adorally at the antisiphuncular side of the conch (visible in specimen FMNH-P30423 and in holotype, Fig. 9D-E).

The diameter of the septal perforation of the holotype is ca 0.25 of the corresponding conch height and positioned between the center and conch margin with an rSP of 0.21 . This is identical to the mean of the $\mathrm{rSP}$ of all five measurements from the available specimens (mean se $=0.21$; minimum measured $\mathrm{rSP}=$ 0.21 , maximum measured $\mathrm{rSP}=0.21 ; \mathrm{n}=5$ ). The mean relative siphuncular diameter of all measured specimens is 0.25 (range of rSD: $0.23-0.28 ; \mathrm{n}=6$ ) (Fig. 34). 
The sutures are directly transverse. The relative chamber length varies between 0.26 and 0.58 in four measured specimens (FMNH-P30421, P30422, P30423, P30430) and decreases with conch height (Fig. 34).

The septal necks are short, orthochoanitic, and in the holotype $0.6 \mathrm{~mm}$ long where the corresponding chamber length is ca $5 \mathrm{~mm}$. The connecting ring is thin, and its segments expand slightly into the chambers (Figs 11B, 35A). The siphuncle is completely filled with endosiphuncular deposits in the holotype at a conch height of $14 \mathrm{~mm}$ and $16 \mathrm{~mm}$, leaving only a questionable $0.6 \mathrm{~mm}$ central canal. At a conch height of $17 \mathrm{~mm}$ the ventral half of the siphuncle is completely filled with a massive endosiphuncular deposit. In the holotype, episeptal deposits are developed at the pro-siphuncular (ventral) side of the conch.

\section{Comparison}

This species is unique among species of Buttsoceras with regard to its elliptically compressed conch cross section. The type species of Buttsoceras, B. adamsi, differs in having a nearly circular to slightly depressed conch cross section and a transversally striated conch surface. The center of the siphuncle of this species is at a position with a distance of ca 0.35 of the conch height from the conch margin; this is more eccentric than in the specimens of Buttsoceras sp. of the Croisaphuill Formation (late Floian Stage), Scotland, UK (compare Evans 2011).

Genus Protocycloceras Hyatt, 1900

\section{Type species}

Orthoceras lamarcki Billings, 1859, from the Fort Cassin Formation (Floian Stage), Township of Godmanchester, Huntingdon County, southwest Quebec; by original designation.

\section{Diagnosis}

Nearly straight, annulated longicones with circular or subcircular cross section and straight sutures; camerae narrow, about 6-7 over a length similar to conch cross section; siphuncle located between center and ventral conch margin; siphuncular segments concave; septal necks short, loxochoanitic to orthochoanitic; connecting ring comparatively thick; siphuncular deposits wedge out adorally at steep angle to ventral side; diaphragms in apical portions of siphuncle; epi-and hyposeptal cameral deposits more strongly developed on ventral side (adopted from Kröger \& Landing 2009).
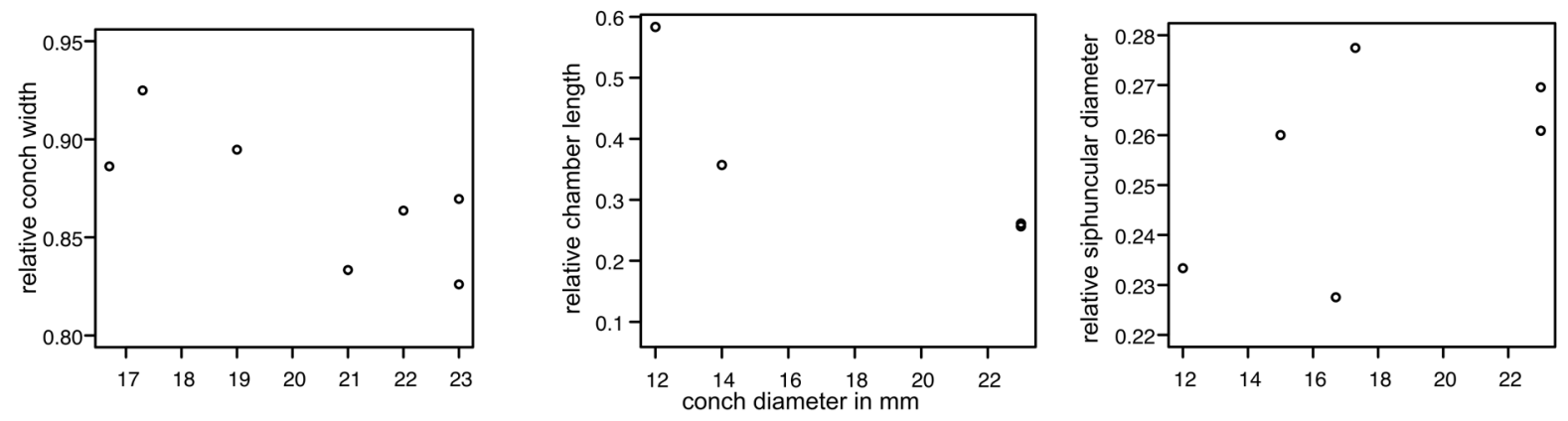

Fig. 34. Diagrams of relative conch width, relative chamber length, and relative siphuncular diameter of Buttsoceras buldrebreenensis sp. nov., from the Olenidsletta Member, Floian, Ordovician, Profilstranda section, Ny Friesland, Spitsbergen. See Supp. file 1 for details of measurements. 


\section{Remarks}

The genus Protocycloceras is type genus for the Protocycloceratidae Kobayashi, 1935. Based on the cladistic analysis (below) this family is abandoned. The genus clusters consistently with other members of the Troedsonellida, such as Buttsoceras (see below). The close relationship between the two genera is also suggested by the combination of diaphragms and endosiphuncular linings, which is unknown in any other genus.

Protocycloceras lamarcki (Billings, 1859)

Figs 36I, 37A-B

Orthoceras lamarcki Billings, 1859: 362, fig. 11f-h.

Protocycloceras lamarcki - Kröger \& Landing 2009: 679-681, figs 10.5, 10.6, 11.6-8 (cum syn). Evans 2011: 82-94, pl. 13 figs 6-9, 11-39, pl. 14 figs 1-16, pl. 15 figs 9-10, text-figs 22-26, table 14 (cum syn).

\section{Diagnosis}

Slightly curved longicones with prominent undulation; conch cross section circular-subcircular; ribs directly transverse, rounded, concave interspaces; ribs and interspaces similar in size and shape; one rib and a concave interspace correspond to one chamber; sutures directly transverse; approximately 4-5 chambers over a length similar to conch cross section; siphuncle eccentric between center of conch and ventral conch margin; siphuncular diameter approximately one third of conch cross section; siphuncular segments concave; septal necks short, loxochoanitic to orthochoanitic; connecting ring thick; endosiphuncular rod in ventral part of siphuncle, fills entire siphuncle in more adapical part; rod wedges out adorally with steep angle toward the venter; diaphragms in adapical portions of siphuncle; epi- and hyposeptal deposits present (from Kröger \& Landing 2009).
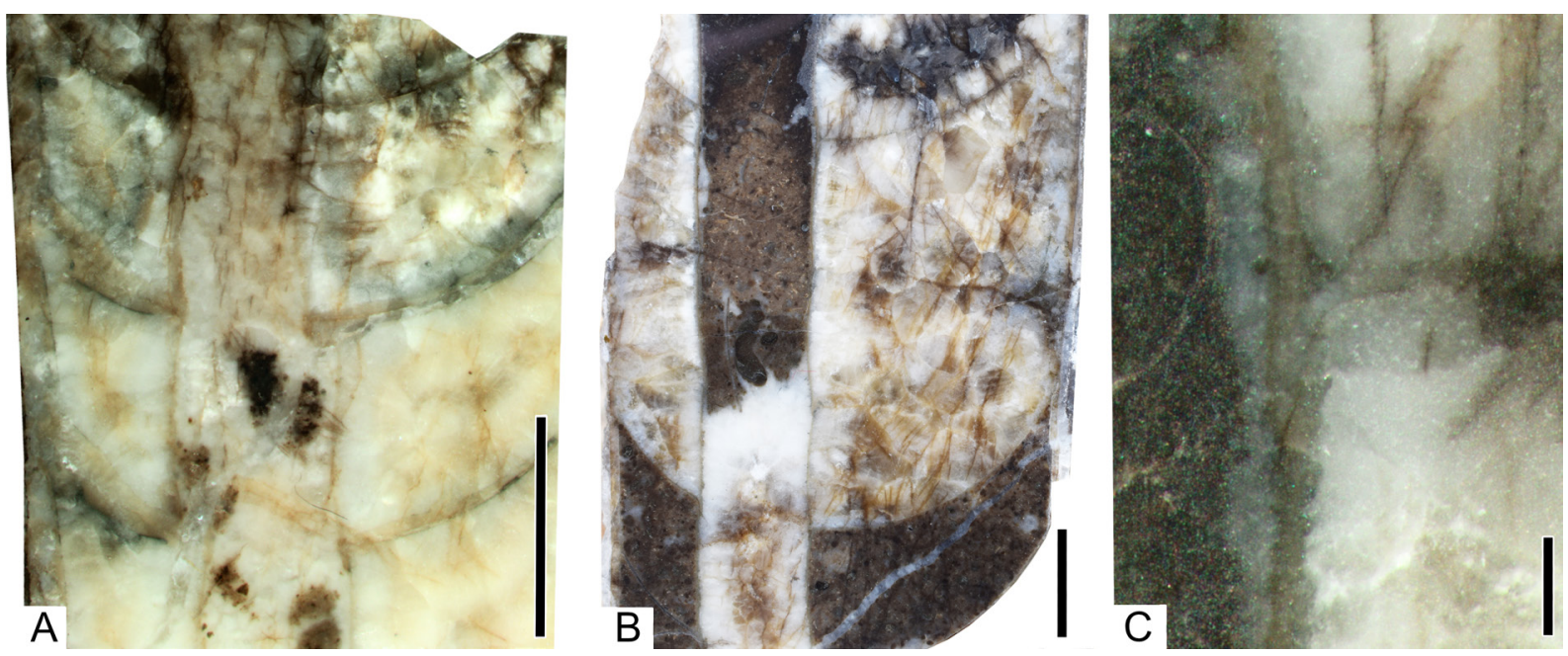

Fig. 35. Median sections of phragmocones of Buttsoceras buldrebreenensis sp. nov. from bed PO 131, from the Olenidsletta Member, Floian, Ordovician, Profilstranda section, Ny Friesland, Spitsbergen. A. Specimen FMNH-P30421, heavily recrystallized phragmocone, ventral side toward the left, see Fig. 11B for interpretation. B-C. Specimen FMNH-P30430, septa are only partly preserved. C. Detail of $\mathrm{B}$ with loxochoanitic septal neck and connecting ring relatively well preserved. Scale bars: $\mathrm{A}-\mathrm{B}=$ $5 \mathrm{~mm} ; \mathrm{C}=1 \mathrm{~mm}$. 


\section{Material examined}

Specimen FMNH-P30409, from Profilstranda section, adjacent to Hinlopenstretet, Spitsbergen, from bed PO 3.7, $0.7 \mathrm{~m}$ above base of Olenidsletta Member, and specimen FMNH-P30418 from bed PO 04, $1 \mathrm{~m}$ above base of Olenidsletta Member, both V1a trilobite zone, Blackhillsian, Floian.

\section{Description}

Specimen FMNH-P30418 consists of a portion of a phragmocone and $3 \mathrm{~mm}$ of the basal part of the body chamber. In total, the length of the specimen exceeds $24 \mathrm{~mm}$. The conch cross section is slightly subcircular with a diameter of $6.5-8.0 \mathrm{~mm}$. The exact angle of expansion is unknown.

The surface is ornamented with rounded, directly transverse ribs, which run parallel to the sutures and are very slightly shifted toward the apex at the prosiphuncular side, forming a very shallow ventral sinus (Fig. 36I). Approximately one rib and one valley occur per chamber, and ca four ribs occur in a distance similar to corresponding conch cross section.
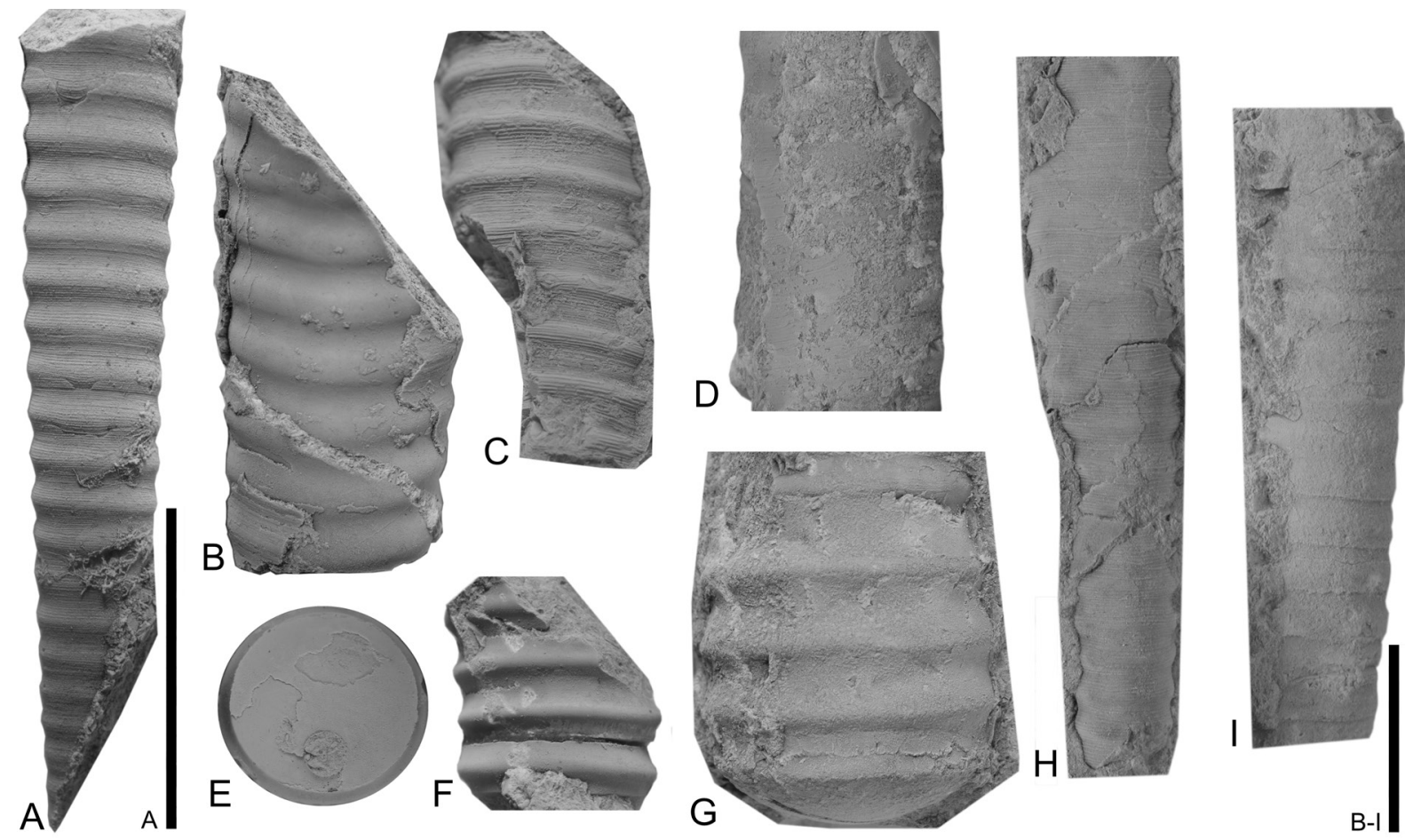

Fig. 36. Protocycloceratid cephalopods from the Olenidsletta Member, Floian, Ordovician, Profilstranda section, Ny Friesland, Spitsbergen. A. Protocycloceras sp. FMNH-P30417, lateral view, from bed PO 123.3. B-C, E-H. Protocycloceras minor sp. nov. B, E-F. Specimen FMNH-P30411, holotype, from bed PO 131. B. Ventral view, prosiphuncular side. C. Specimen FMNH-P30412, from bed PO 131, with details of ornamentation well preserved. D. Catoraphiceras sp., FMNH-P30425, from bed PO 131, oblique lateral view. E. Adoral view of holotype with septal perforation visible. F. Fragment of holotype with chamber spacing G. Specimen FMNH-P30413 showing the shape of the septal curvature, dorsal view, antisiphuncular side. H. Specimen FMNH-P30410, with conch surface well preserved. I. Protocycloceras lamarcki (Billings, 1859), FMNH-P30418, from bed PO 04, with poorly preserved conch surface. Scale bars $=5 \mathrm{~mm}$. 
The three adoral chambers counted from body chamber toward apex measure $1 \mathrm{~mm}, 1.4 \mathrm{~mm}$, and $1.7 \mathrm{~mm}(\mathrm{rCL}=0.25-0.21)$ and probably represent adult septal chambers. The siphuncle is at least $2.2 \mathrm{~mm}$ in diameter $(\mathrm{rSD}=0.28)$; the distance from the ventral conch margin cannot be measured with certainty but is approximately $1.4-1.8 \mathrm{~mm}(\mathrm{rSP}=0.18-0.25)$.

The siphuncular segments are strongly concave and the connecting rings are thick. The septal necks of the two adoralmost chambers are preserved and are relatively long (ca $0.6-0.7 \mathrm{~mm}$ ) and loxochoanitic (Fig. 37A). An interpretation of the endosiphuncular structure is difficult because of the state of preservation of the specimen, but episeptal and mural cameral deposits are visible in the polished section of the specimen.

A second specimen, FMNH-P30409, is a naturally weathered sagittal cut of a phragmocone, exposing the siphuncle and the central parts of the septa. The conch is straight and slender. The conch cross section is only known from the ventral parts and does not allow any inference on the cross-section shape. The surface is weakly annulated with ca one undulation per chamber. The chambers have a distance of ca $1.2-0.7 \mathrm{~mm}$. The siphuncle is $0.8 \mathrm{~mm}$ in diameter, with weakly concave segments and orthochoanitic septal necks, and has no endosiphuncular deposits. Episeptal cameral deposits are present in specimen FMNH-P30409.

\section{Remarks}

The morphological characters of the two specimens, including shape and spacing of annulation, spacing of septa, siphuncular position and relative thickness and the preserved details of the connecting ring and septal necks all are within the well documented (Kröger \& Landing 2009; Evans 2011) variability of $P$. lamarcki.
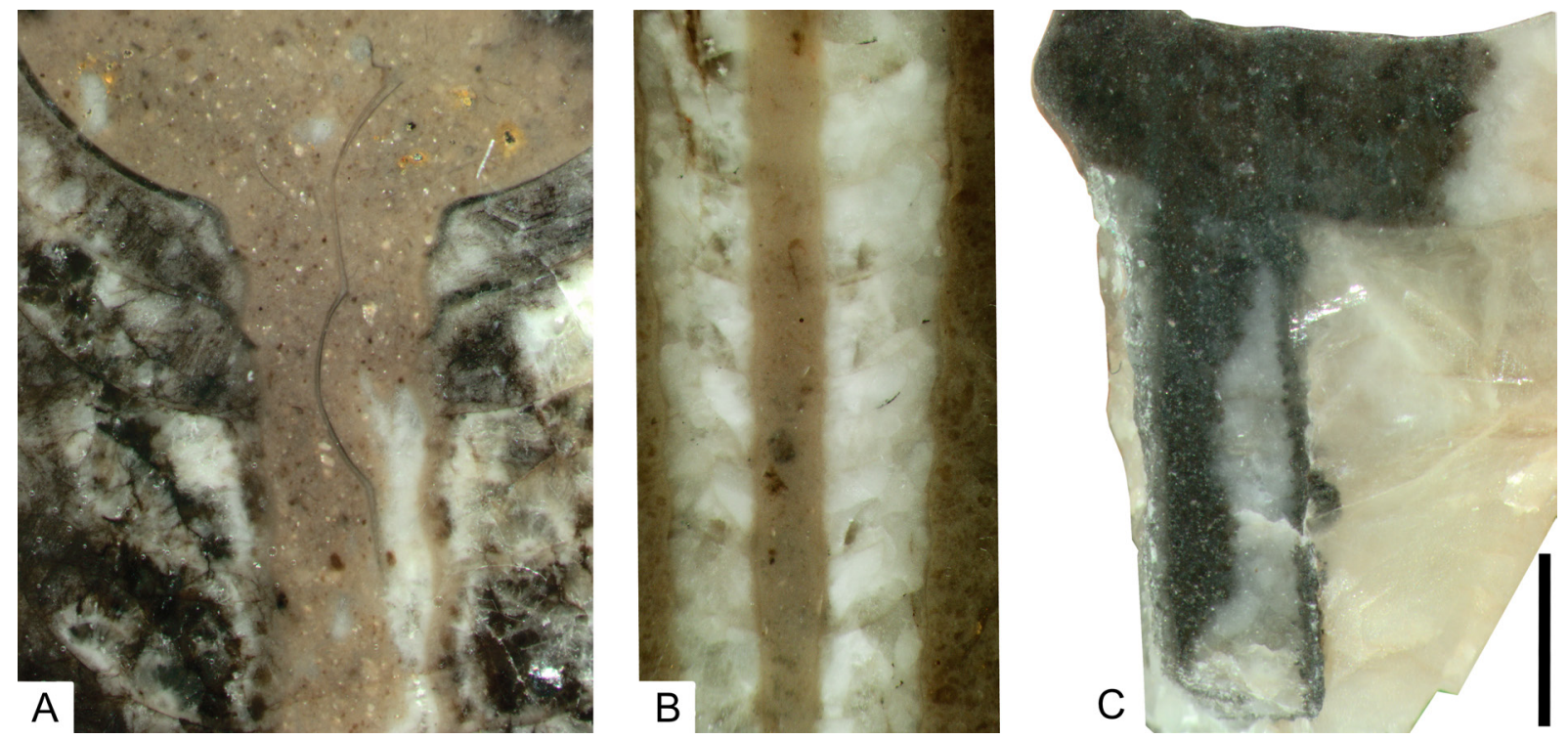

Fig. 37. Longitudinal cross sections of protocycloceratid cephalopods from the Olenidsletta Member, Floian, Ordovician, Profilstranda section, Ny Friesland, Spitsbergen. A-B. Protocycloceras lamarcki (Billings, 1859). A. Specimen FMNH-P30418, approximal dorso-ventral median section with details of heavily recrystallized siphuncle and sepal necks, showing concave siphuncular segments. B. Specimen FMNH-30409, apical fragment of phragmocone with cameral deposits and siphuncle with concave segments and orthochoanitic septal necks. C. Protocycloceras minor sp. nov., FMNH-P30411, holotype, with poorly preserved details; siphuncle with nearly tubular segments and probably short orthochoanitic septal necks. Scale bar $=2 \mathrm{~mm}$ for all figures. 
This justifies the assignment of these fragments to $P$. lamarcki, herein. It should be noted, however, that specimen FMNH-P30418 probably represents an adult specimen (based on adult septal crowding). With an adult size of only $8 \mathrm{~mm}$ it is clearly smaller than many specimens measured from the Fort Cassin Formation, New York, USA, which reach conch diameters of more than $30 \mathrm{~mm}$ (Kröger \& Landing 2009) and from the Durness Group, Scotland, UK (Evans 2011), which reach diameters of ca $25 \mathrm{~mm}$.

\section{Stratigraphic and geographic range}

Widespread in North America (see details in Kröger \& Landing 2009), Scotland, UK (see review in Evans 2011), and Spitsbergen, herein, Floian Stage.

Protocycloceras minor sp. nov. urn:1sid:zoobank.org:act:C3D57CD1-2758-40A3-8596-6865D77F3620

Figs 36B-C, E-H, 37C, 38

\section{Etymology}

From the Latin 'minor', 'relatively small', referring to the relatively small size of this species of Protocycloceras.

\section{Type material}

\section{Holotype}

Specimen FMNH-P30411.

\section{Paratypes}

Five additional specimens (FMNH-P30410, P30412 to P30415) all from type horizon and locality.

\section{Type locality and horizon}

From Profilstranda section, adjacent to Hinlopenstratet, Spitsbergen, bed PO 131, $128 \mathrm{~m}$ above base of Olenidsletta Member, V2 trilobite zone, Blackhillsian, Floian.

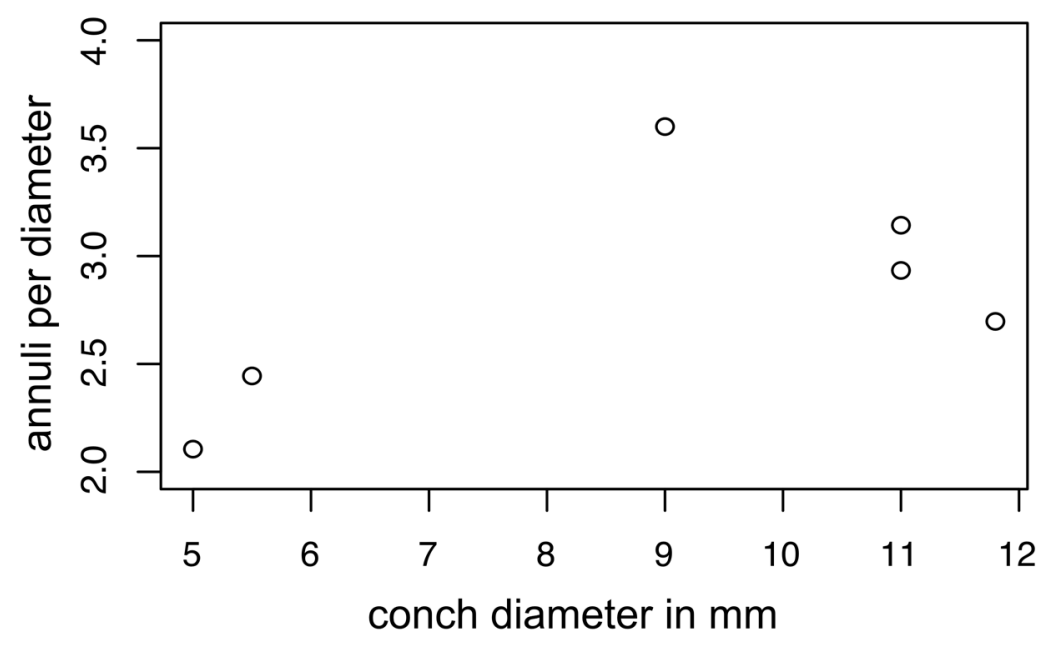

Fig. 38. Diagram of the spacing of the annulation in Protocycloceras minor sp. nov. from the Olenidsletta Member, Floian, Ordovician, Profilstranda section, Ny Friesland, Spitsbergen. See Supp. file 1 for details of measurements. 


\section{Description}

The holotype is a fragment of a body chamber and part of the phragmocone with a nearly circular conch cross section of $9.5 \mathrm{~mm}$ in diameter (Fig. 36B, E-F). The preservation does not allow precise measurement of the angle of expansion. The preserved part of the body chamber is $12 \mathrm{~mm}$ long. The conch is annulated, with annulations running parallel to the sutures with a distance of ca $2 \mathrm{~mm}$ and a chamber length of ca $2 \mathrm{~mm}$ (ca 4-5 chambers and annulations per corresponding cross section diameter).

The siphuncle is nearly tubular, has a diameter of $2.1 \mathrm{~mm}(\mathrm{rSD}=0.22)$, and is located ca $0.7 \mathrm{~mm}$ from the conch margin $(\mathrm{rSP}=0.07)($ Fig. $37 \mathrm{C})$. The holotype has two complete septa preserved with a distance of $2.2 \mathrm{~mm}$ at a corresponding conch cross section of $9.5 \mathrm{~mm}(\mathrm{rCL}=0.23)$. The septal necks are poorly preserved but appear to be orthochoanitic and with a length of ca $0.5 \mathrm{~mm}$.

The conch cross section is circular to subcircular and grows with an angle of expansion of $\mathrm{ca}^{\circ}$ in the two other measured specimens (FMNH- P30410, FMNH-P30414). The septal perforation was measured in FMNH-P30412 and FMNH-P30415 with some inaccuracy because of poor preservation and varies from 0.29 to 0.34 in the two specimens. The conch surface in all specimens is ornamented with ribs and transverse striae. The ribs are directly transverse and run parallel to the sutures; they are very slightly shifted toward the apex at the prosiphuncular side, forming a very shallow ventral sinus. The ribs are more sharply rounded than the valleys, ca one rib and one concave interspace occur per chamber, and ca 3 ribs occur per distance similar to corresponding conch cross section. The relative spacing of the annulation increases with increasing conch diameter (Fig. 38). Additionally, the surface is ornamented with ca 15-20 fine transverse striae or growth lines per annulation. The largest specimen in the collection has a diameter of ca $12 \mathrm{~mm}$ (specimen FMNH-P30415).

\section{Comparison}

The siphuncle is more eccentric ( $\mathrm{rSP} \approx 0.1$ in $P$. minor sp. nov. compared with 0.25 in P. lamarcki) and

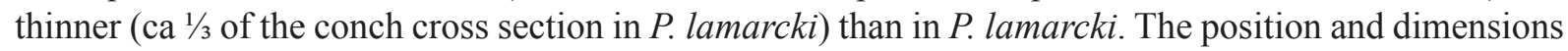
of the septal perforation are similar to those of Castelloceras arennigense Evans, 2005, from the Bohaul Member of the Ogof Hên Formation, Moridunian Regional Stage (Floian), which is slightly older than division V2 of the Olenidsletta Member. However, the details of the siphuncle are not known from that species, which precludes further comparison.

\section{Protocycloceras sp.}

Fig. 36A

\section{Material examined}

Specimen FMNH-P30417 from Profilstranda section, bed PO 123.3, $120.3 \mathrm{~m}$ above base of Olenidsletta Member, V2a trilobite zone, Blackhillsian, Floian.

\section{Description}

The specimen is an orthoconic fragment of a phragmocone with a circular conch cross section $2.0-5.5 \mathrm{~mm}$ in diameter and $17 \mathrm{~mm}$ long (angle of expansion $12^{\circ}$ ). The specimen is ornamented with a transverse annulation, the annuli slope very slightly toward the aperture at the antispihuncular side, ca 3 annuli occur per distance similar to the corresponding conch diameter. Additionally, fine striae occur, which run parallel to the annulations, ca 20 striae occur per one millimeter. The chamber distance is roughly similar to the distance of the annuli; at the adoral end of the specimen the chamber length is $1.5 \mathrm{~mm}$. There the siphuncle is $0.75 \mathrm{~mm}$ in diameter $(\mathrm{rSD}=0.14)$ and positioned ca $0.6 \mathrm{~mm}$ from the conch margin (rSP $=0.1$ ). The connecting ring segments are slightly concave and relatively thick, and the septal necks are orthochoanitic to loxochoanitic with a length of $0.4 \mathrm{~mm}$, where the chamber length is $1.5 \mathrm{~mm}$. 


\section{Remarks}

This specimen differs from $P$. minor sp. nov. in having a very thin siphuncle $(\mathrm{rSD}=0.14$, compared with $\mathrm{rSD}=0.22$ in P. minor). Hence, it is morphologically transitional to Slemmestadoceras attavus (Brøgger, 1882) and Kyminoceras forresti Teichert \& Glenister, 1954, which have a thin marginal siphuncle, and C. arennigense and P. lamarcki which have a much thicker siphuncle, that is positioned close to the conch center. However, based on this single, small fragment the erection of a new species would be not justified and it will be left in open nomenclature until more material is available.

Order Orthocerida Kuhn, 1949

Family Baltoceratidae Kobayashi, 1935

Genus Eosomichelinoceras J.-Y. Chen, 1974

\section{Type species}

Eosomichelinoceras huananense J.-Y. Chen, 1974, from the Middle Ordovician of Southwest China; by original designation.

\section{Diagnosis}

Smooth or transversally striated, slender, orthoconic baltoceratids with narrow, tubular siphuncle. Siphuncle is eccentric with $\mathrm{rSP}$ of more than 0.2 , and with $\mathrm{rSD} \approx 0.2$ or less. Septal necks are orthochoanitic. Endosiphuncular or cameral deposits are not known (adopted from Kröger et al. 2007).

Eosomichelinoceras borealis sp. nov. urn:lsid:zoobank.org:act:C53AC527-FC9D-4433-A853-5BF9AE4C2B6C

Figs $12 \mathrm{C}, \mathrm{F}-\mathrm{G}, 13 \mathrm{~B}, 28 \mathrm{C}, 33 \mathrm{C}-\mathrm{E}, 39-40$

\section{Diagnosis}

Eosomichelinoceras with circular to slightly compressed conch cross section; conch in early growth stages slightly curved; shell surface ornamented with narrowly spaced transverse striae which form shallow hyponomic sinus at concave side of conch curvature; siphuncle eccentric, at convex side of conch curvature with rSP of 0.36 , relative siphuncle diameter $(\mathrm{rSD})$ ca 0.16 of corresponding conch cross section; septal necks loxochoanitic during earliest growth stages, orthochoanitic during later ontogeny; ca three chambers per length similar to corresponding conch cross section; connecting ring thin, tubular or slightly expanded.
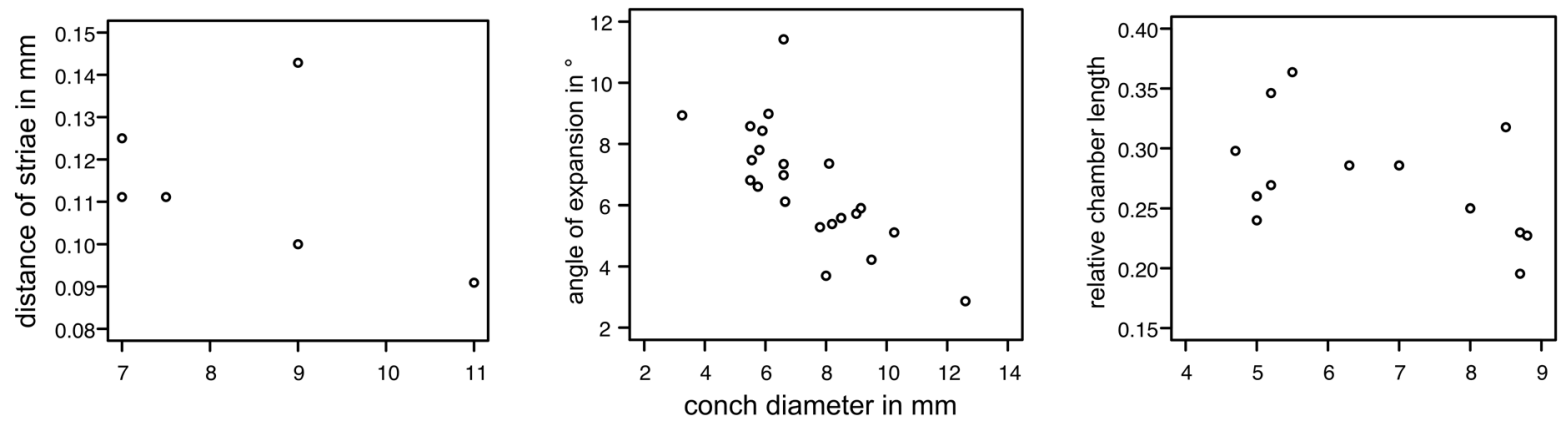

Fig. 39. Diagrams of spacing of ornamentation, angle of expansion, and relative chamber length of Eosomichelinoceras borealis gen. et sp. nov., from the Olenidsletta Member, Floian, Ordovician, Profilstranda section, Ny Friesland, Spitsbergen. See Supp. file 1 for details of measurements. 


\section{Etymology}

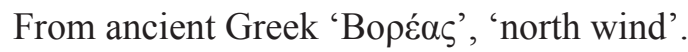

\section{Type material}

\section{Holotype}

Specimen FMNH-P30279.

\section{Paratypes}

Fourty-one specimens (FMNH-P30171, P30182, P30193, P30278, P30280 to P30318, P30434; see Supp. file 1 for list of specimens) from type horizon and one specimen from bed PO 131, $128 \mathrm{~m}$ above base of Olenidsletta Member, all from type locality. Additionally, two microscopic fragments (FMNH-P30170, FMNH-P30184) from type horizon and one (FMNH-P30182) from bed PO 131.

\section{Type locality and horizon}

From Profilstranda, adjacent to Hinlopenstretet, Spitsbergen, bed PO 123.3, $120.3 \mathrm{~m}$ above the base of the Olenidsletta Member, V2a trilobite zone, Blackhillsian, Floian.

\section{Description}

Conch with circular to slightly compressed cross section, exogastrically curved in juvenile growth stages, becoming nearly straight in growth stages with diameter $>10 \mathrm{~mm}$. The holotype (specimen FMNH-P30279) is a fragment of a phragmocone which growths within a length of $53 \mathrm{~mm}$ from 3.2 to $10 \mathrm{~mm}$ (angle of expansion ca $7^{\circ}$ ). The largest conch cross section diameter known is $11.5 \mathrm{~mm}$ (specimen FMNH-P30297), which is a completely preserved, nearly straight body chamber with a length of $28 \mathrm{~mm}$ and an angle of expansion of ca $5^{\circ}$. The low angle of expansion of this fragment indicates that a diameter of ca $12 \mathrm{~mm}$ is probably the adult size of this species (see also Fig. 39).

The ornamentation consists of fine striae, which run slightly obliquely transverse, which are deflected adorally on the convex side of the conch and form a shallow, but distinct hyponomic sinus at the concave side of the conch curvature (Fig. 13B). The holotype is ornamented with 7-10 transverse striae in a length of $1 \mathrm{~mm}$ where the conch is $9 \mathrm{~mm}$ in diameter. Six random measurements from the holotype and other specimens result in a mean distance of $0.11 \mathrm{~mm}$ between striae.

The sutures are directly transverse with a mean relative chamber length of 0.28 of the corresponding cross section. The chamber length is $2.0-2.5 \mathrm{~mm}$ at $8-9 \mathrm{~mm}$ conch diameter in the holotype. The septal

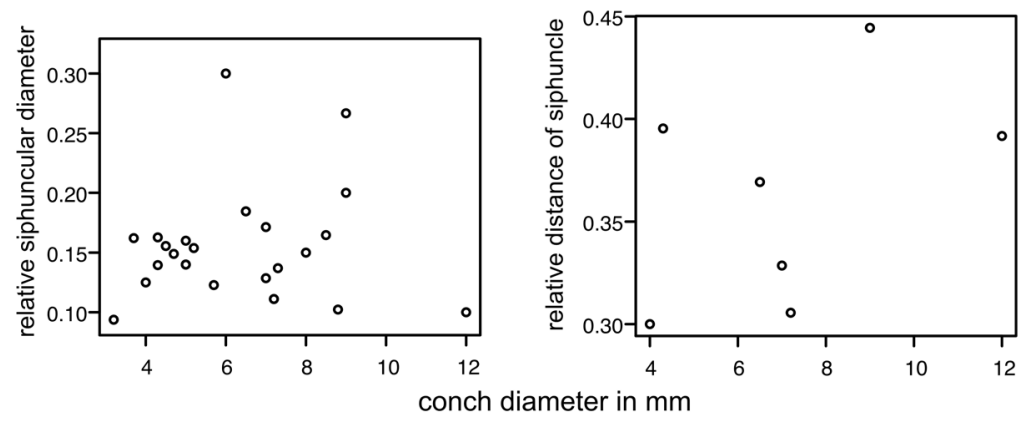

Fig. 40. Diagrams of relative siphuncular diameter and relative siphuncular distance of Eosomichelinoceras borealis gen. et sp. nov. from the Olenidsletta Member, Floian, Ordovician, Profilstranda section, Ny Friesland, Spitsbergen. See Supp. file 1 for details of measurements. 
perforation has a mean relative diameter of 0.16 in all measured specimens ( $\mathrm{rSD} 1^{\text {st }-3^{\text {rd }}}$ quantile: $0.13-$ $0.16 ; \mathrm{n}=26)$.

The siphuncle is eccentrically positioned, with $\mathrm{rSP} \approx 0.36$ on the convex side of the conch curvature $\left(1^{\text {st }}-3^{\text {rd }}\right.$ quantile: $\left.0.32-0.38 ; n=5\right)$ (Fig. 40$)$. The septal necks are short loxochoanitic in specimen FMNH-P30193 at $7 \mathrm{~mm}$ diameter conch diameter and orthocoanitic in larger fragments with a larger conch diameter (Figs 28C, 33C-E). The connecting ring is thin with tubular or slightly expanded segments. No endosiphuncular or cameral deposits known.

The extreme apical part is preserved in specimens FMNH- P30171, FMNH-P30182, and FMNH-P30184 (Fig. 12C, F-G). The initial ca $1.5 \mathrm{~mm}$ in both specimens are set apart from the subsequent shell in being distinctly bent in growth direction toward the convex side of the curvature of the subsequent shell, which is the prosiphuncular side. The initial ca $1.5 \mathrm{~mm}$ differs also in lacking the fine transverse striation of the subsequent conch parts. The protoconch has a very distinctive stump-like form with a diameter of $1 \mathrm{~mm}$ (specimen FMNH-P30182) and $1.4 \mathrm{~mm}$ (specimen FMNH-P30184), and a length of $0.9 \mathrm{~mm}$ (specimen FMNH-P30182) and $0.7 \mathrm{~mm}$ (specimen FMNH-P30184). The shaft is endogastrically curved and starts at a diameter of $1.2 \mathrm{~mm}$ (specimen FMNH-P30184) and $0.9 \mathrm{~mm}$ (specimen FMNH-P30182), respectively. The conch grows toward $2.8 \mathrm{~mm}$ within ca $17 \mathrm{~mm}$ in FMNH-P30184, and reaches $2.3 \mathrm{~mm}$ within ca $15 \mathrm{~mm}$ in FMNH-P30182. A second distinct change in growth pattern occurs at a diameter of ca 1.5-1.7 mm and is best seen in specimen FMNH-P30171. There, the conch curvature abruptly decreases and the angle of expansion increases (Fig. 12C).

\section{Stratigraphic and geographic range}

$120.3 \mathrm{~m}$ (PO 123.3) and $128 \mathrm{~m}$ (PO 131) above base of Olenidsletta Member, V2 trilobite zone, Blackhillsian, Floian.

\section{Comparison}

Eosomichelinoceras borealis sp. nov. is unique among Eosomichelinoceras in having a slightly curved juvenile conch and a relatively wide angle of expansion of ca $7^{\circ}$. The type species differs additionally in having a wider chamber spacing. In addition, in Eosomichelinoceras guizhouense Yang, 1978 the siphuncle is more central in position; in Eosomichelinoceras ordosoense Chen \& Zou, 1984 additionally the siphuncle is more eccentrically positioned. Eosomichelinoceras baldisii Kröger et al., 2007 differs from the new species in having a compressed conch cross section. Apical parts of species assigned to Eosomichelinoceras are only known so far from specimens from the Olenidsletta Member, making a comparison of this growth stage with other species impossible at present.

Order Tarphycerida Flower in Flower \& Kummel, 1950

Family Tarphyceratidae Hyatt, 1894

Genus Cycloplectoceras Ulrich, Foerste, Miller \& Furnish, 1942

\section{Type species}

Cycloplectoceras miseri Ulrich, Foerste, Miller \& Furnish, 1942, from the Smithville Formation (Floian Stage), north of Smithville, Lawrence County, Arkansas, USA; by original designation.

\section{Diagnosis}

Small discoidal conch with nearly circular whorls in cross section; whorls are in contact and slightly impressed dorsally; extremely small umbilical perforation; surface ornamented with strong annulations and prominent growth lines, which form $\mathrm{v}$-shaped ventral sinuses; sutures simple and nearly straight; siphuncle near the ventral wall of the conch (from Ulrich et al. 1942). 
Cycloplectoceras hinlopense sp. nov. urn:1sid:zoobank.org:act:17CC19A8-797C-4718-AE09-C6DEEF037258

Fig. 41C-D

\section{Diagnosis}

Strongly ribbed Cycloplectoceras with rapidly enlarging conch with WER of ca 3.7 and LER of ca 2, with adult size $>30 \mathrm{~mm}$.

\section{Etymology}

From Hinlopen Strait, referring to the type region of this species.

\section{Type material}

\section{Holotype}

Specimen FMNH-P30327; by monotypy.

\section{Type locality and horizon}

From Profilstranda section, Ny Friesland, Svalbard, bed PO 131, $128 \mathrm{~m}$ above base of Olenidsletta Member, Blackhillsian, Floian.

\section{Description}

Specimen FMNH-P30327 is a fragment of a phragmocone consisting of ca two whorls with a total diameter of $26 \mathrm{~mm}$. The conch grows with a WER of 3.66 and a LER of 2. The whorl is $13 \mathrm{~mm}$ wide and high at a conch diameter of $26 \mathrm{~mm}$ and is slightly flattened on the lateral flanks and venter; a $0.3 \mathrm{~mm}$ deep imprint zone is present at the dorsum.

The conch is strongly annulated with ribs than run obliquely transverse across the flanks and forming a deep and broad ventral lobe. Prominent growth lines or striae are present, ca 8 per one millimetre, and are parallel to the ribs.

The siphuncular perforation has a diameter of $1.4 \mathrm{~mm}$ and is positioned at a distance of $1.3 \mathrm{~mm}$ from the venter $(\mathrm{rSP}=0.1)$. The septal spacing is relatively narrow; where the conch is $22 \mathrm{~mm}$ in diameter the sutures have a distance of $2 \mathrm{~mm}$ apart over the venter.

\section{Remarks}

This specimen is assigned to Cycloplectoceras because it is a ribbed tarphycerid with rapidly enlarging whorls, both in whorl height and in whorl width. The conch cross section is nearly circular, similar as in known species of Cycloplectoceras. Pionoceras Ulrich et al., 1942 is another annulated tarphycerid with high WER and rapid growth of the whorl width. Pionoceras, however, differs in having broadly subtrapezoidal whorl cross sections and a very broad venter. The fragment described above is, however, relatively small, and ontogenetic growth changes are frequent among tarphycerid species, and especially among species of Pionoceras. It is therefore possible that this specimen represents a fragment of a larger individual, which if fully preserved would exhibit an adult morphology with an aspect of Pionoceras. More material is required to fully document the ontogeny, and consequently to further support the generic assignment of this species.

Cycloplectoceras hinlopense sp. nov. differs from C. miseri Ulrich, Foerste, Miller \& Furnish, 1942 in being larger (the adult size of $C$. miseri is only $20 \mathrm{~mm}$ ). The other known species of Cycloplectoceras, C. funatum Ulrich, Foerste, Miller \& Furnish, 1942, has a smaller rate of increase in relative conch width (LER = ca 1.2, compare Ulrich et al. 1942: pl. 6 fig. 7) and is less strongly annulated. 
Genus Deltoceras Hyatt, 1894

\section{Type species}

Deltoceras planum Hyatt, 1894, from strata of the St. George Group (Lower Ordovician) at Port au Choix, north side, western Newfoundland, Canada; by original designation.

\section{Emended diagnosis}

Rapidly expanding evolute conch possessing whorls with a compressed cross section with very shallow or lacking zone of impression; adoral portion of conch divergent from preceding whorl at maturity; no conspicuous shell sculpture; sutures form weak lateral lobes; siphuncle subventral in position (adopted from Evans 2011).

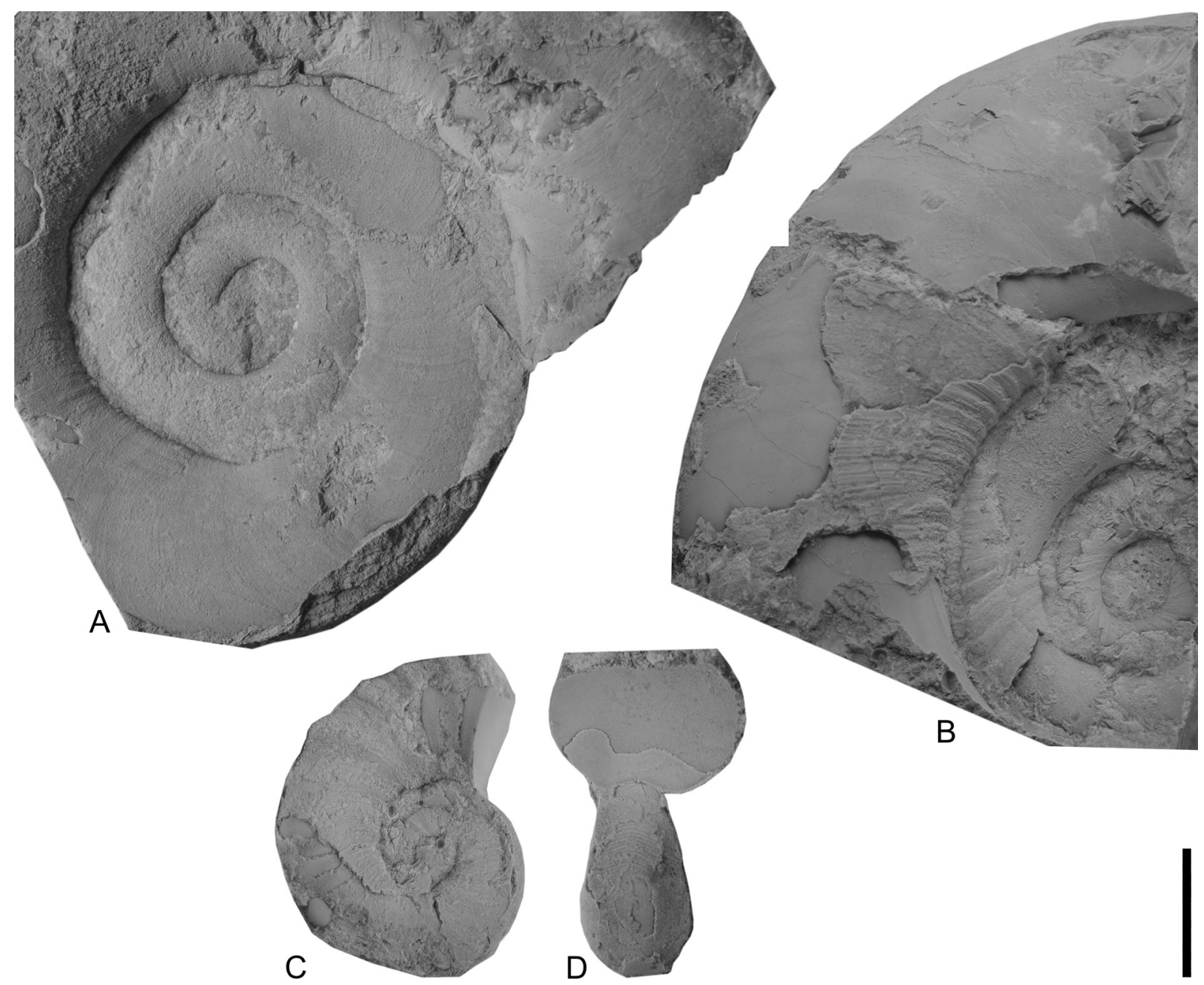

Fig. 41. Coiled cephalopods from the Olenidsletta Member, Floian, Ordovician, Profilstranda section, Ny Friesland, Spitsbergen. A. Deltoceras beluga sp. nov., FMNH-P30322, from bed PO 07. B. Trocholitoceras walcotti Hyatt, 1894, FMNH-P30328, from bed PO 131. C-D. Cycloplectoceras hinlopense sp. nov., FMNH-P30327, holotype, from bed PO 131. Scale bar $=10 \mathrm{~mm}$ for all figures. 


\section{Remarks}

The exact location of the only known specimen of the type species is given in Hyatt (1894: 450) as "Port au Choix, north side" without specifying wether this relates to the Port au Choix peninsula or the town of Port au Choix. Deltoceras is listed under doubtful taxa in Teichert (1964), but Evans (2011) revived the genus and provided a concise diagnosis adopted from Ulrich et al. (1942), which is used herein. The genus diagnosis is slightly emended and expanded, herein, from being exclusively without dorsal impression zone to also having a very shallow impressive zone, in order to include Deltoceras beluga sp. nov. We justify this emendation also based on the poor knowledge on the details of the single specimen of the type species, which may also during earlier growth stages have a slightly involute conch curvature. The emphasis of this genus now is the combination of strongly compressed smooth whorls with a subventrally positioned siphuncle.

Deltoceras beluga sp. nov. urn:lsid:zoobank.org:act:197BA0EF-574D-4EEF-ADC3-DF120829D7C5

Figs 41A, 42-43, 44A

\section{Diagnosis}

Discoidal, slightly involute conch with moderately expanding whorls with relative whorl width (rW) of ca $0.7-08$ and with slightly flattened venter. Ornamented with fine growth lines, which form broad lateral lobe and deep hyponomic sinus.

\section{Etymology}

From the Beluga whale Delphinapterus leucas (Pallas, 1776) a common guest offshore of Profilstranda in the Hinlopen Strait, Svalbard.
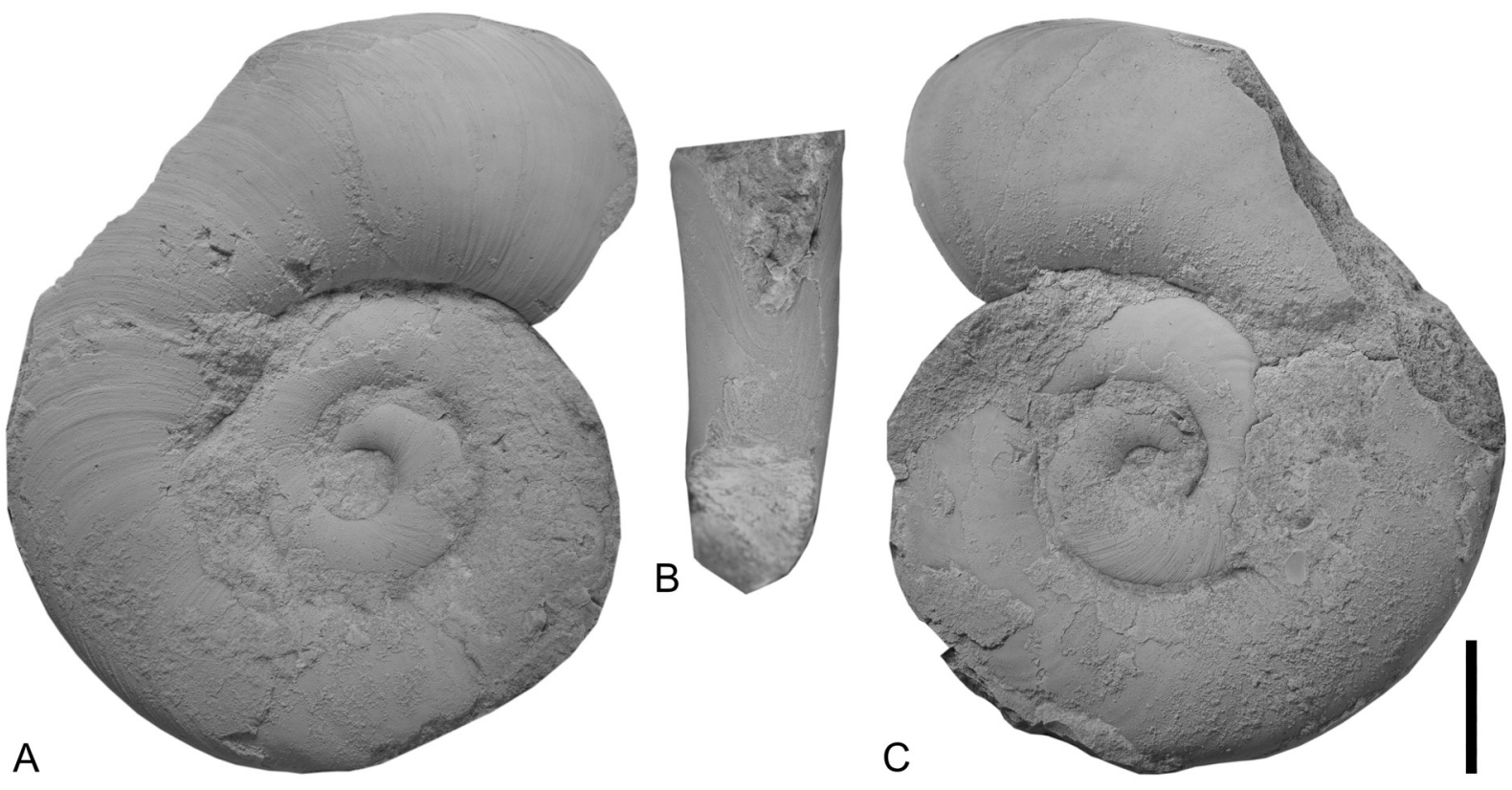

Fig. 42. Deltoceras beluga sp. nov., FMNH-P30321, holotype, from bed PO 07, from the Olenidsletta Member, Floian, Ordovician, Profilstranda section, Ny Friesland, Spitsbergen. A. View from right side. B. Ventral view; note the deep u-shaped hyponomic sinus. C. View from left side. Scale bar $=10 \mathrm{~mm}$. 


\section{Type material}

Holotype

Specimen FMNH-P30321.

\section{Paratypes}

Two additional specimens, FMNH-P30322 and FMNH-P30326, from type locality and horizon.

\section{Type locality and horizon}

From Profilstranda section, Ny Friesland, Svalbard, from bed PO 07, $4 \mathrm{~m}$ above base of Olenidsletta Member, V1a trilobite zone, Blackhillsian, Floian.

\section{Description}

The holotype is a complete specimen of ca 2.5 volutions, with a conch diameter of $42 \mathrm{~mm}$ and an apertural conch width and height of $12 \mathrm{~mm}$ and $15 \mathrm{~mm}$, respectively (WWI $=0.8$ ) (Fig. 42). The relative whorl width (rW) varies between 0.7 and 0.8 in the holotype. The conch grows with a WER of 2.78-1.96 between the first and last whorl and thus decreases with increasing diameter (Fig. 43). The whorls are rounded at the flanks with greatest width at ca the first third of the conch height from dorsum, ventral side slightly flattened and dorsum with shallow zone of impression (Fig. 44A). Zone of impression ca $1 \mathrm{~mm}$ deep at aperture.

The conch surface is ornamented with irregularly spaced fine growth lines which form a broad lobe across the flanks and a deep, rounded, V-shaped hyponomic sinus. Hyponomic sinus at aperture of holotype ca $10 \mathrm{~mm}$ deep. The completely preserved body chamber has a length of $250^{\circ}$ at the dorsum and $220^{\circ}$ at the distal end of the hyponomic sinus.

The septa form a broad lateral sinus and have a ventral distance of ca $4 \mathrm{~mm}$ at a conch diameter of $28 \mathrm{~mm}$. The umbilical window is ca $3 \mathrm{~mm}$ in diameter in the holotype.

\section{Comparison}

Besides the type species only one other species of Deltoceras was known. This second species, D. vangeni Ruedemann, 1906 from the Chazy Group, Valcour Island, New York, USA, has a nearly circular cross section and probably is an estonioceratid. The new species differs from the type species of Deltoceras in having a conch cross section with a slightly flattened venter and a shallow impression zone at the
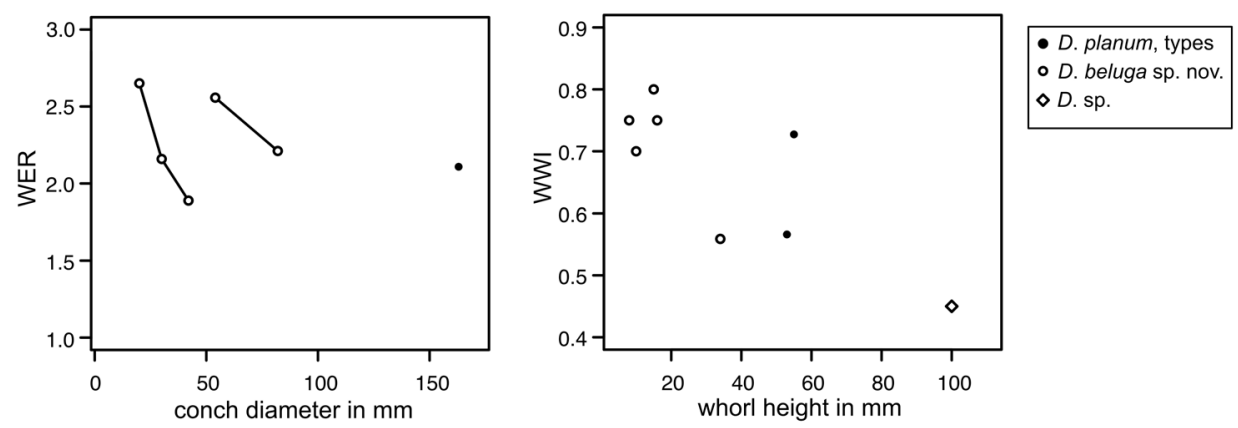

Fig. 43. Diagrams of whorl expansion rate (WER) and whorl width index (WWI) of Deltoceras beluga sp. nov., from the Olenidsletta Member, Floian, Ordovician, Profilstranda section, Ny Friesland, Spitsbergen. Solid lines connect measurements from individual specimens. Data of type specimens of D. planum Hyatt, 1894 from Ulrich et al. (1942). See Supp. file 2 for details of measurements 
dorsum. Because the early volutions of the type species are not known and the three specimens known from the Olenidletta Member are relatively small compared with the type specimen, the possibility exists that the Olenidsletta Member specimens are conspecific with D. planum and represent earlier growth stages. The assignment of Deltoceras to the Estonioceratidae (see Evans 2011) or alternatively into the Tarphyceratidae (herein) is questionable and depends on a better knowledge of the type species. Here we place the genus provisionally in the Tarphyceratidae because of an assumed shallow dorsal impression during earlier growth stages in D. planum.

Family Estonioceratidae Hyatt in Zittel, 1900

Gen. et sp. indet. A

Fig. 45E-F

\section{Material examined}

Specimen FMNH-P30342, from Profilstranda section, Ny Friesland, Svalbard, bed PO 7.5, $4.5 \mathrm{~m}$ above base of Olenidsletta Member, V1a trilobite zone, Blackhillsian, Floian.

\section{Description}

The specimen is a slightly curved, ca $19 \mathrm{~mm}$ long part of a body chamber, with a circular conch cross section with a diameter of $10.5 \mathrm{~mm}$ at the position of the last septum and $11 \mathrm{~mm}$ at the adoral end. The body chamber is simple conical, without constriction, and with a very shallow hyponomic? sinus at the concave side of the curvature. The conch surface is nearly smooth, ornamented only with very fine directly transverse growth lines. The shell is relatively thick, $1 \mathrm{~mm}$ at the base of the body chamber. The suture is directly transverse, and the septum has a concavity of ca $1.5 \mathrm{~mm}$. The septal perforation is ca $1 \mathrm{~mm}$ in diameter and positioned ca $0.5 \mathrm{~mm}$ from the convex margin of the conch.

\section{Remarks}

The body chamber is strongly curved but lacks an impression zone, and with the exception of the last septum the phragmocone is not preserved, which shows that the curvature is exogastric and the
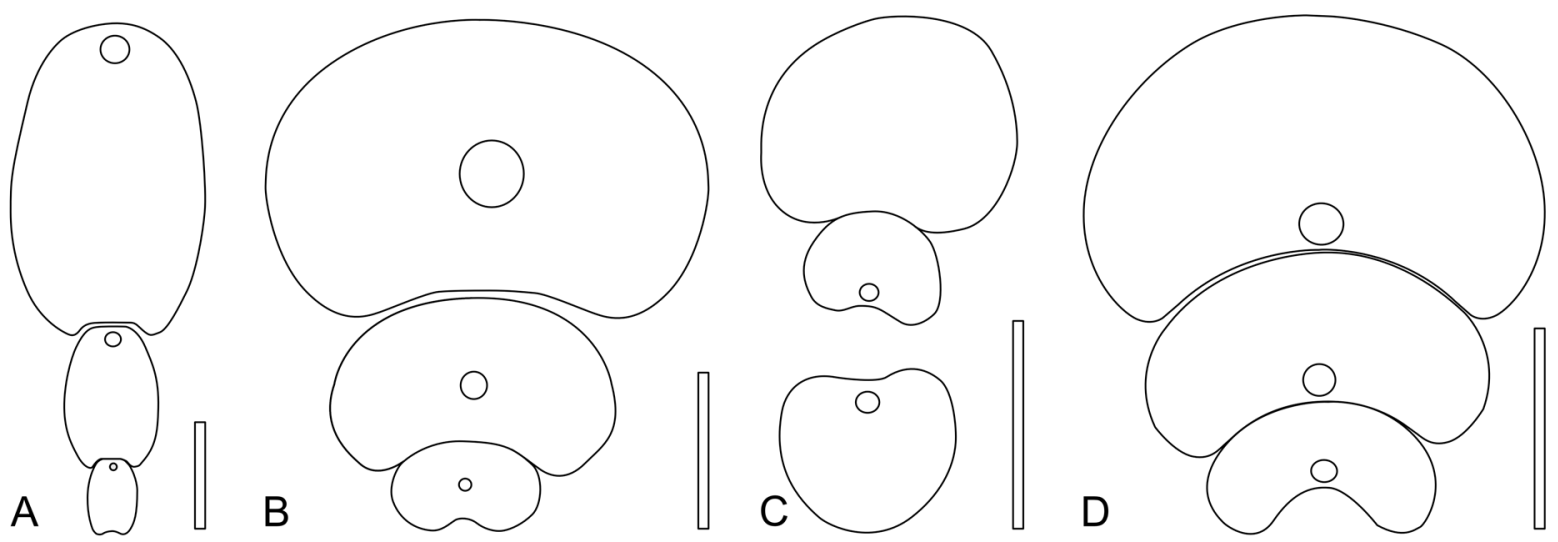

Fig. 44. Cross sections of coiled cephalopods from the Olenidsletta Member, Floian, Ordovician, Profilstranda section, Ny Friesland, Spitsbergen with details of siphuncular position and impression zone of conch. A. Deltoceras beluga sp. nov., FMNH-P30322, from bed PO 07. B. Litoceras profilbekkenense sp. nov, FMNH-P30329, holotype, from bed PO 131, C. Trocholitoceras juvenicostatum Ulrich et al., 1942, FMNH-P30324, from bed PO 131. D. Trocholitoceras walcotti Hyatt, 1894, FMNH-P30328, from bed PO 131. Scale bars $=10 \mathrm{~mm}$. 
siphuncle is positioned close to the conch margin. The available characters indicate that the fragment is part of an estonioceratid, but a more specific determination is impossible with the material at hand.

Family Trocholitidae Chapman, 1857

Genus Litoceras Hyatt, 1884

\section{Type species}

Nautilus versutus Billings, 1865 (part), from Gargamelle Cove, Pointe Riche Peninsula, western Newfoundland, Canada (lower Table Head Formation, Darriwilian, see Stouge 1984); by original designation.
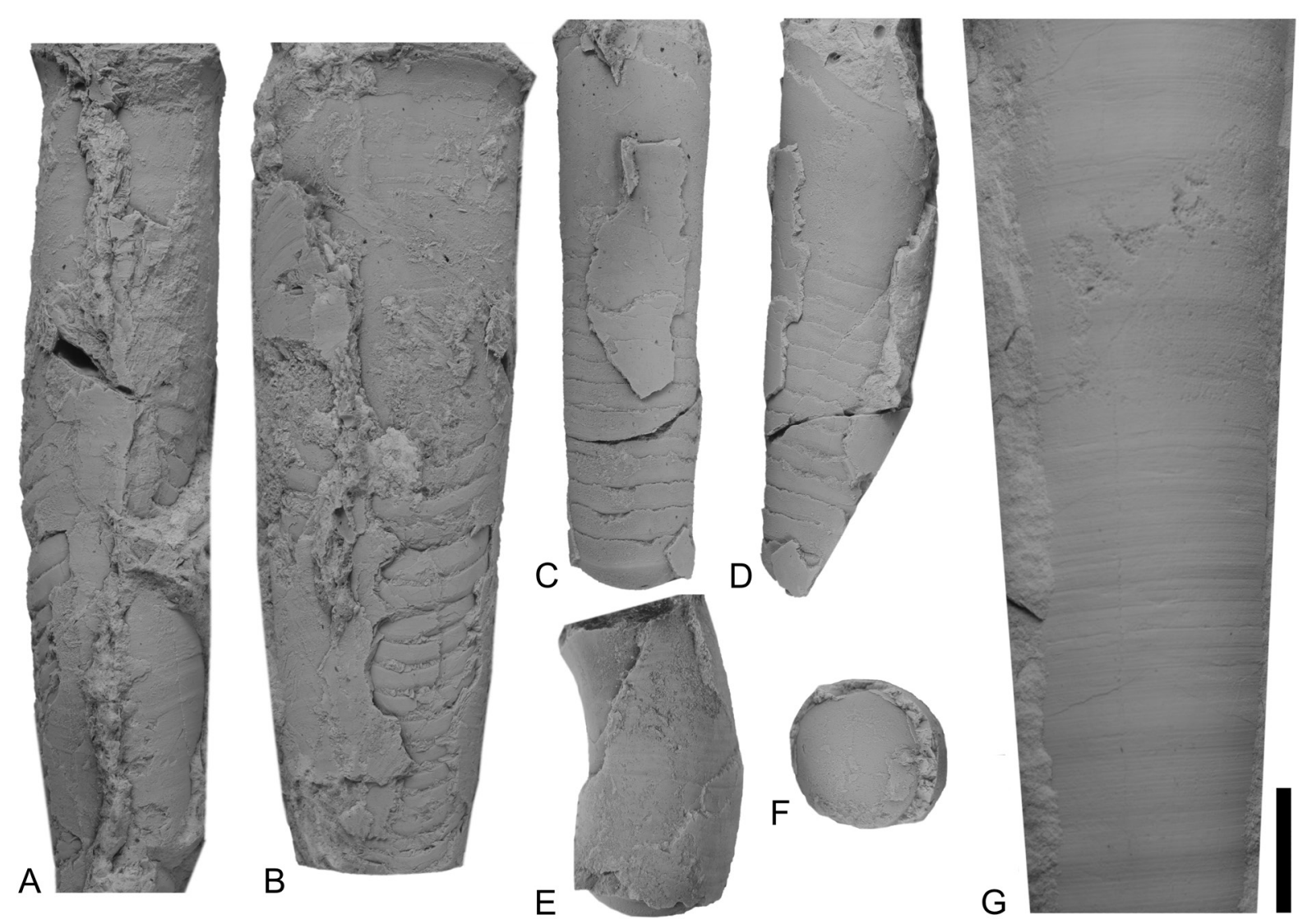

Fig. 45. Cephalopods from the Olenidsletta Member, Floian, Ordovician, Profilstranda section, Ny Friesland, Spitsbergen. A-B. Nyfrieslandoceras bassleroceroides gen. et sp. nov., FMNH-P30353, holotype, from bed PO 131. A. Ventral view, prosiphuncular side. B. Lateral view with ventral, prosiphuncular side toward the left. C-D. Order, gen. et sp. indet. A, FMNH-P30354, from bed PO 131. C. Dorsal (?) view. D. Lateral view, with dorsal (?), antisiphuncular side toward the right. E-F. Estonioceratid gen. et sp. indet. A., FMNH-P30342, from bed PO 7.5. E. Lateral view with ventral, prosiphuncular side toward the right. F. adoral view with preserved siphuncular perforation. G. Order, gen. et sp. indet. B, FMNH-P30424, from bed 4.8., lateral view with ventral, prosiphuncular side toward the right. Scale bar $=10 \mathrm{~mm}$ for all figures. 


\section{Diagnosis}

Thickly subdiscoidal to subglobular conchs with rapidly enlarging, depressed whorls; mature body chamber may become evolute; ornamented with growth lines, which slope apicad from the umbilical shoulder to the hyponomic sinus, growth lines may become fasciculate, and costae may develop which are not, however, prominent, and are not ordinarily evident on the internal mold; straight transverse sutures or faint ventral saddles may develop; siphuncle initially ventral, dorsal by the completion of the second volution (adopted from Flower 1968: 44).

\section{Remarks}

The type specimens (originally described as Nautilus versutus, referred to L. whiteavesi Hyatt, 1894 by Hyatt 1894: 475) have been listed as collected from the St. George and/or Table Head Group of western Newfoundland in Ulrich et al. (1942: 78). However, Flower (1979: 223) stated "after extensive collecting of coiled cephalopods, both from the St. George Group and in the Table Head limestone, it is clear that there is no true Litoceras in the St. George Group nor in any known late Canadian faunas. Specimens very close to L. versutum have been obtained in the Table Head limestone, from which I have obtained at least 35 large coiled cephalopods; all but one belong to Litoceras".

Litoceras profilbekkenense sp. nov. urn:1sid:zoobank.org:act:847E0904-7D05-46EF-81F3-EDA8A5F740A7

Figs 44B, 46-47

\section{Diagnosis}

Litoceras with relatively slender, rapidly enlarging conch, with WER of 2.3; with reniform, depressed conch cross section and WWI of ca 1.3; ornamented with fine growth lines which run obliquely across the flanks and form broad hyponomic sinus; the siphuncle is relatively wide, ca 0.25 of apertural height, and at a distance of 0.25 of the corresponding apertural height from the dorsum.

\section{Etymology}

Referring to the Profilbekken River near the type locality.

\section{Type material}

\section{Holotype}

Specimen FMNH-P30329; by monotypy.

\section{Type locality and horizon}

From Profilstranda section, Ny Friesland, Svalbard, PO 131, 128 m above base of Olenidsletta Member, Blackhillsian, Floian.

\section{Description}

This specimen is a tectonically distorted fragment of a phragmocone and parts of a ca $180^{\circ}$ long body chamber with a conch diameter of $86 \mathrm{~mm}$ (Fig. 46). The base of the body chamber is at a conch diameter of $58 \mathrm{~mm}$, where the conch has ca three volutions, a whorl height of $21 \mathrm{~mm}$, an apertural height of $20 \mathrm{~mm}$ and a conch width of $28 \mathrm{~mm}$. The WER of the conch at the base of the body chamber is 2.3 (see Fig. 47 for comparison). In cross section the whorls are reniform and show a very broad, almost flattened venter and rounded flanks.

The conch surface is ornamented with pronounced growth lines and is otherwise smooth or with very low ribs. The septal perforation at the base of the body chamber is subcentrally positioned at a distance 
of ca $5 \mathrm{~mm}$ from the dorsal margin and has a diameter of ca $5 \mathrm{~mm}$. The sutures are simple and directly transverse.

\section{Remarks}

This specimen falls within the range of variability of Trocholitoceras walcotti with respect to the IZR, WWI, and general conch cross section shape (see Fig 47); however, at a comparable conch size it has a much larger WER than $T$. walcotti and the siphuncle is wider and subcentrally positioned, as seen in Litoceras. Litoceras calciferum (Billings, 1865), L. insolens (Billings, 1865), L. versutum (Billings, 1865), and L. huygenae Flower, 1968 have broader whorls. In L. whiteavsi Hyatt, 1894 the rounded flanks are more convex. Litoceras avus Barrande, 1870 (see Flower 1979) and L. adamsi Flower, 1968 have a similar WER (2.3), but the whorl cross section and exact position of the siphuncle is not known from the former, and the whorl cross section is wider in the latter. Litoceras was previously restricted to the Middle Ordovician. Notably, several specimens of Litoceras with comparatively high whorls, which are still wider than those of $L$. profilbekkenense sp. nov., occur in basal Whiterockian strata in Nevada, USA (Flower 1968). These strata are only slightly younger than division V2 of the Olenidsletta Member (Fortey 1980; Fortey \& Droser 1999; Loch \& Ethington 2017), where L. profilbekkenense sp. nov. occurs. Therefore, L. profilbekkenense sp. nov. may be seen as a morphological and stratigraphical link between the predominantly Floian Trocholitoceras and the predominantly Middle Ordovician Litoceras.
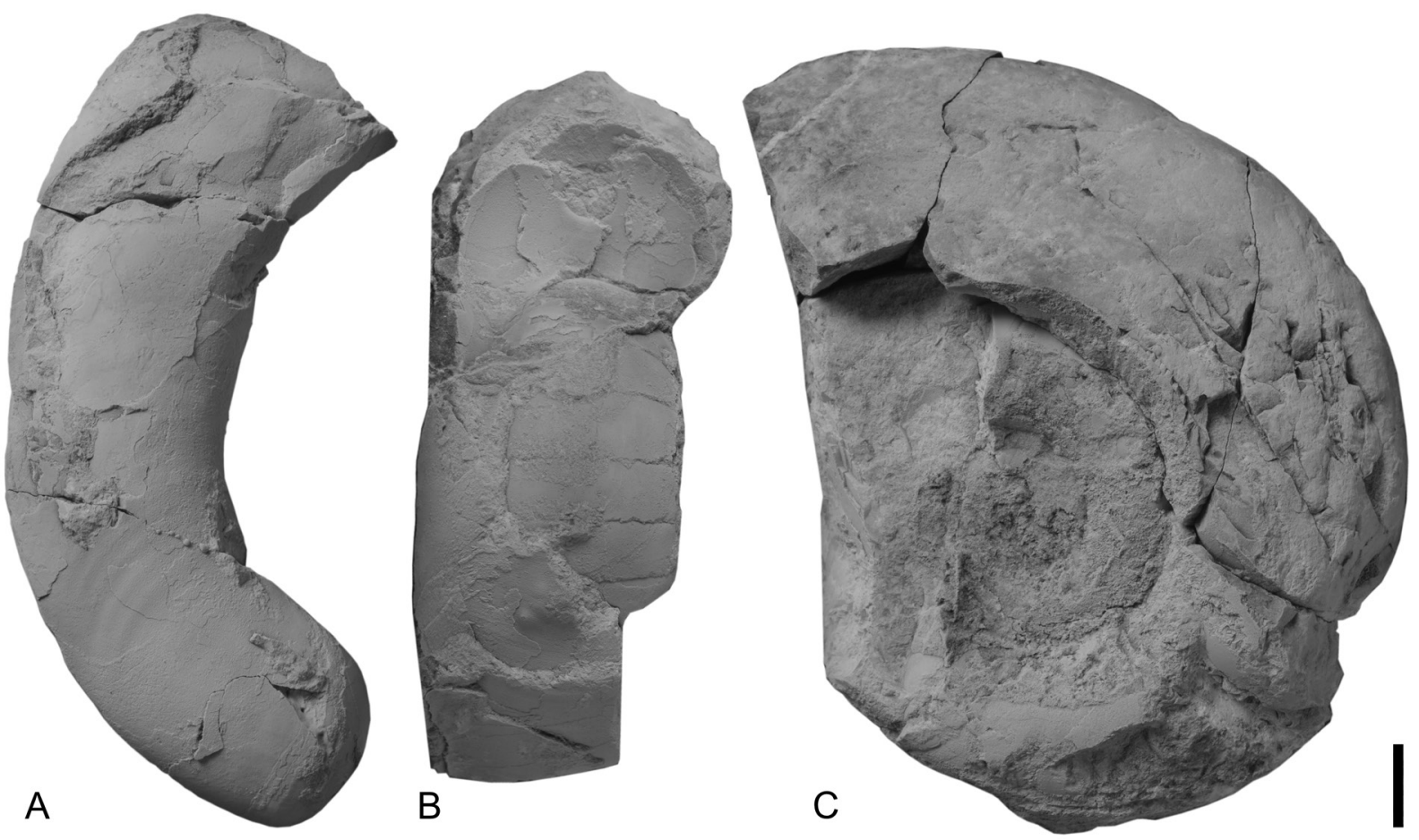

Fig. 46. Litoceras profilbekkenense sp. nov., FMNH-P30329, holotype, from bed PO 131, from the Olenidsletta Member, Floian, Ordovician, Profilstranda section, Ny Friesland, Spitsbergen. A. Lateral view of left side of fragment of body chamber. B. Ventral view and whorl cross section with siphuncular perforation preserved. C. Lateral view of right side. Scale bar $=10 \mathrm{~mm}$ for all figures. 
Genus Trocholitoceras Hyatt, 1894

\section{Type species}

Trocholitoceras walcotti Hyatt, 1894, from the Fort Cassin Limestone (late Floian Stage), Fort Cassin, Addison County, Vermont, USA; by original designation.

\section{Diagnosis}

Moderately large, subdiscoidal, involute conchs with a ca $180^{\circ}$ long body chamber; umbilical perforation very small; ornamented with prominent, partly fasciculate growth lines and low ribs which form a deep rounded ventral sinus; sutures directly transverse and nearly straight except on dorsal side where they form a shallow lobe; siphuncle small, subcentral during early adolescence, dorsal or nearly so at maturity (from Ulrich et al. 1942: 80).

Trocholitoceras walcotti Hyatt, 1894

Figs 41B, 44D, 47

Trocholitoceras walcotti Hyatt, 1894: 480-482, pl. 6 figs 12-20.

Trocholitoceras latum Ulrich et al., 1942: 82-83, pl. 42 figs 1-3.

Trocholitoceras walcotti - Ruedemann 1906: 478. — Ulrich et al. 1942: 80-81, pl. 31 fig. 3, pl. 53 figs 3-4. — Dzik 1984: 44, text-fig. 12.34.

\section{Diagnosis}

Trocholitoceras with moderately expanding whorls with WER decreasing during growth from ca 2 to 1.7 ; whorl cross section moderately involute with average IZR 0.26 , and depressed with WWI decreasing with conch size from more than 2 to less than 1.5; conch surface ornamented with prominent transverse growth lines and low rounded ribs at mature body chamber which curve apicad on the lateral side and form a deep, rounded hyponomic sinus; siphuncle subcentral in earliest growth, subdorsal during later growth; mature conch with diameter ca $90 \mathrm{~mm}$ with 4-5 volutions (compiled from Ulrich et al. 1942: $80-81)$.
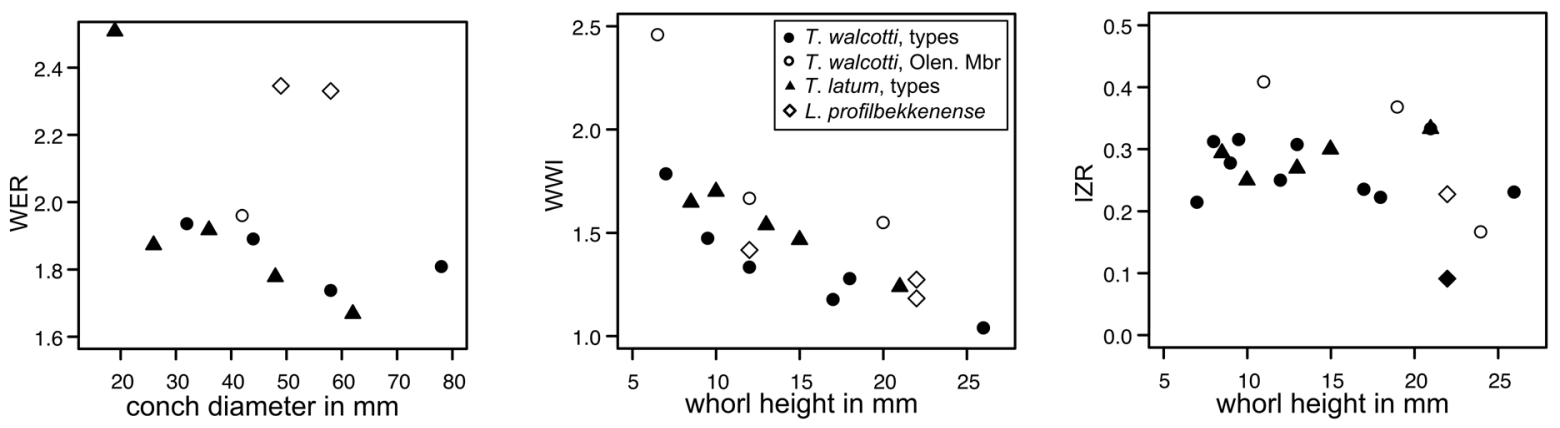

Fig. 47. Diagrams of whorl expansion rate (WER), whorl width index (WWI), and relative depth of impression zone (IZR) of Trocholitoceras walcotti Hyatt, 1894, T. latum Ulrich et al., 1942, and Litoceras profilbekkenense sp. nov. Measurements from specimens from the Olenidsletta Member (Olen. Mbr), Floian, Ordovician, Profilstranda section, Ny Friesland, Spitsbergen, and from type specimens based on Ulrich et al. (1942). See Supp. file 2 for details of measurements. 


\section{Material examined}

Three specimens (FMNH-P30325, FMNH-P30328, FMNH-P30333) from Profilstranda section, Ny Friesland, Svalbard, bed PO 131, $128 \mathrm{~m}$ above base of Olenidsletta Member, Blackhillsian, Floian.

\section{Description}

The most complete specimen is FMNH-P30328 with a presumed conch diameter of more than $80 \mathrm{~mm}$ and the last volution slightly evolute (Fig. 41B). At a conch diameter of $42 \mathrm{~mm}$ the whorl is $20 \mathrm{~mm}$ wide, $19 \mathrm{~mm}$ high, with an apertural height of $12 \mathrm{~mm}$, and an impression zone with a depth of 6-7 mm. The depression of the whorl decreases with increasing diameter, with WWI nearly 2.5 at an apertural height of $6 \mathrm{~mm}$ to 1.5 at an apertural height of $20 \mathrm{~mm}$. The WER is 1.96 at a conch diameter of $42 \mathrm{~mm}$ (Fig. 47). The IZR varies between ca 0.1 and 0.4 (Fig. 47). The whorl cross section has broadly rounded flanks and venter (Fig. 44D). The conch surface is ornamented with prominent transverse growth lines. The siphuncle is $2 \mathrm{~mm}$ distant from the dorsal margin in specimen FMNH-P30325, where the apertural height is $6.5 \mathrm{~mm}$, while its and diameter is ca $1 \mathrm{~mm}$. In specimen FMNH-P30328 the siphuncle is nearly marginal at whorl heights greater than $8 \mathrm{~mm}$ and has a diameter $\mathrm{ca}^{1 / 1} 10$ of the apertural height.

\section{Remarks}

Measurements taken from the median cross section of the types of $T$. walcotti and T. latum (Ulrich et al. 1942: text-fig. 22) reveal a large overlap in WER, IZR, and in the relative whorl width (WWI, Fig. 47) between both species. This is especially relevant in the case of the WWI, because T. latum was originally distinguished from T. walcotti based on the broader and lower whorls of the former (Ulrich et al. 1942: 83). The wide overlap suggests synonymy between the two species, with $T$. walcotti having priority. The two specimens from the Olenidsletta Member are slightly less involute, have less depressed whorls at growth stages less than $20 \mathrm{~mm}$, but fall within the variability of the WER of $T$. walcotti and are also similar in whorl cross section shape, ornamentation and position of the siphuncle. Altogether this similarity justifies the assignment of these specimens to T. walcotti. Trocholithoceras walcotti (and T. latum) were previously known from the Fort Cassin Limestone, Vermont and the St. Armand Limestone, Quebec.

Trocholitoceras juvenicostatum Ulrich, Foerste, Miller \& Furnish, 1942 Figs $44 \mathrm{C}, 48$

Trocholitoceras juvenicostatum Ulrich, Foerste, Miller \& Furnish, 1942: 82, pl. 51 fig. 6, pl. 53 figs 5-6, pl. 56 figs $1-3$.

\section{Diagnosis}

Trocholitoceras with relatively narrow whorls and prominent ribs throughout entire growth; sutures directly transverse with dorsal lobe; siphuncle located close to the dorsal wall in mature portions of the phragmocone (compiled from Ulrich et al. 1942: 82).

\section{Material examined}

Six specimens (FMNH-P30323, P30324, P30330, P30332, P30344, P30347), all from Profilstranda section, Ny Friesland, Svalbard, bed PO 131, 128 m above base of Olenidsletta Member, Blackhillsian, Floian.

\section{Description}

Specimen FMNH-P30323 (Fig. 48A-B) is the most complete specimen assigned this species; it is a fragment of a phragmocone, which is partly heavily recrystallized and part of a $140^{\circ}$ long continuously growing body chamber, and which grows with a WER of 2.03. At the base of the body chamber the conch diameter is $37 \mathrm{~mm}$ and the whorl is $16.5 \mathrm{~mm}$ wide and $11 \mathrm{~mm}$ high $(\mathrm{rW}=1.05)$. The slightly 
depressed cross section has flattened flanks, a rounded venter and a shallow imprint zone $(0.6 \mathrm{~mm}$ at whorl height $11 \mathrm{~mm}$ ) (Fig. 44C).

The conch is ornamented with prominent ribs which run obliquely transverse across the whorl and form a deep hyponomic sinus over the venter; ca 20 ribs occur per volution and the distance of the ribs is ca 4 $\mathrm{mm}$ at the base of the body chamber. Additionally, the conch surface is finely striated with ca 5 striae per mm, which run parallel to the ribs. The annulation appears to be constant in amplitude and relative spacing over the entire preserved part of the specimen. On the imprint of the inner shell a wrinkle layer is visible (Fig. 48A).

The septal perforation is ca $2.9 \mathrm{~mm}$ in diameter and positioned sub-dorsally, ca $1.5 \mathrm{~mm}$ from the dorsum at the base of the body chamber. The chamber distance is visible in specimen FMNH-P30324, which is a small fragment of a phragmocone with a conch diameter of $22 \mathrm{~mm}$, where at a conch width of $12 \mathrm{~mm}$
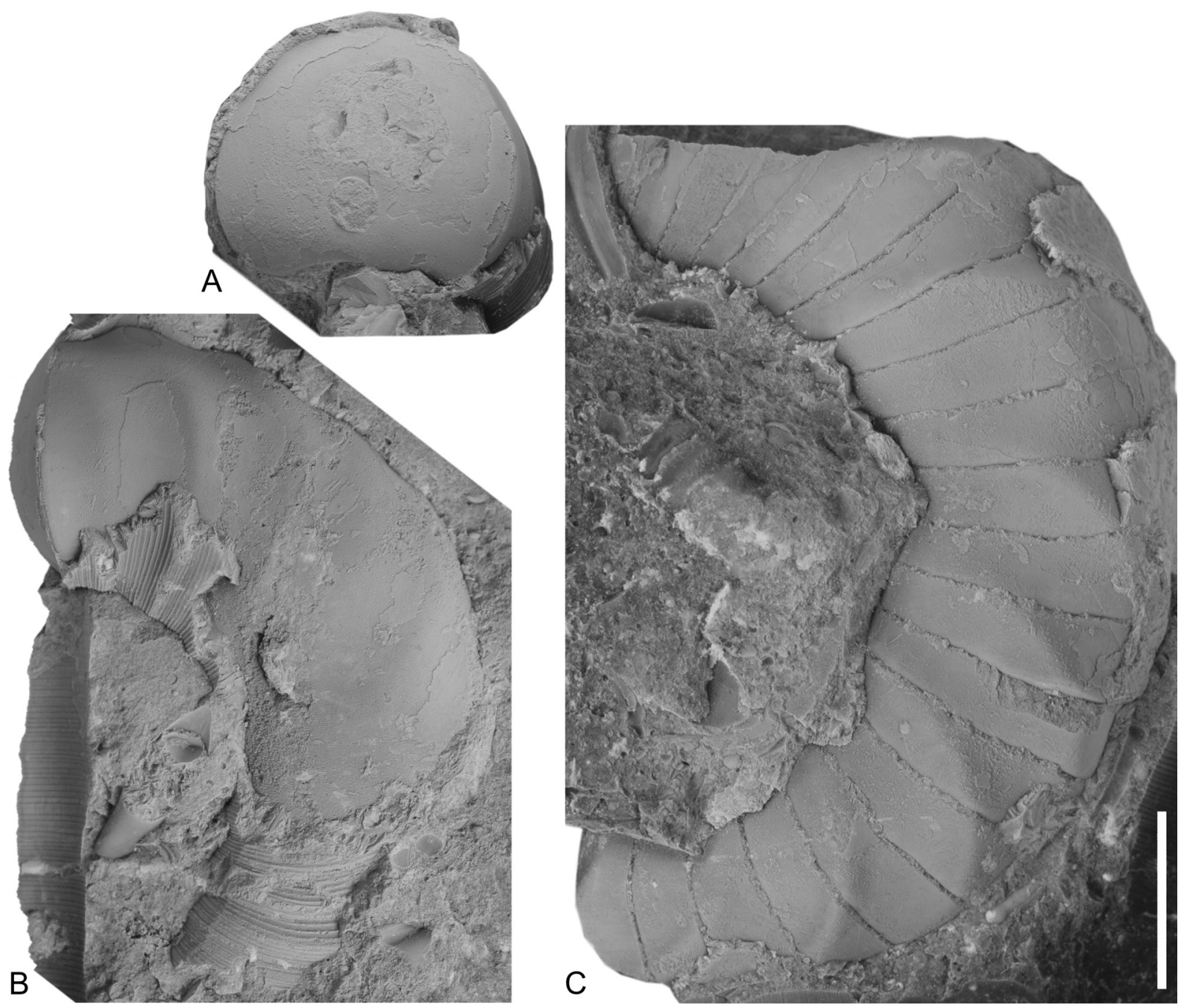

Fig. 48. Trocholitoceras juvenicostatum Ulrich, Foerste, Miller \& Furnish, 1942, from bed PO 131, Olenidsletta Member, Floian, Ordovician, Profilstranda section, Ny Friesland, Spitsbergen. A-B. Specimen FMNH-P30323. A. Adoral view with siphuncular perforation preserved. B. Lateral view of fragment of body chamber with outer shell and ornamentation partly preserved. C. Specimen FMNH-P30330, lateral view with distinctive ribs. Scale bar $=20 \mathrm{~mm}$ for all figures. 
the septal distance is ca $2 \mathrm{~mm}$ at the venter. The sutures are straight and directly transverse. In specimen FMNH-P30332 the whorl width is $15 \mathrm{~mm}$ where the whorl height is $13 \mathrm{~mm}(\mathrm{rW}=1.15)$.

\section{Remarks}

In the type material of T. juvenicostatum, from the St Armand limestone (Middle Ordovician, see Salad Hersi et al. 2007 for age constraint of St. Armand limestone), Quebec, Canada, described by Ulrich et al. (1942), the rW decreases from 1.2 at a whorl height of $6.5 \mathrm{~mm}$ to 0.91 at a whorl height of $12 \mathrm{~mm}$, and the conch grows with a WER of 2.5. This is slightly different from our material. However, the type material of $T$. juvenicostatum is slightly tectonically distorted and the measurements therefore reflect some preservation effects. Also, little is known about intraspecific variation of this species. The assignment of the specimens from the Olendisletta Member to T. juvenicostatum is justified by the presence of prominent ribs, the general similarity of the conch growth rate, shape of the whorl cross section and the subdorsal position of the siphuncle. The other species of Trocholitoceras with prominent ribs, T. phillipsburgense Ulrich, Foerste, Miller \& Furnish, 1942, differs in having a nearly smooth surface in early volutions. Trocholitoceras juvenicostatum was previously known from the St. Armand limestone (Middle Ordovician) of Quebec.

Order Oncocerida Flower in Flower \& Kummel, 1950

Family Phthanoncoceratidae Evans \& King, 1990

Genus Nyfrieslandoceras gen. nov. urn:Isid:zoobank.org:act:46CA8144-915D-4392-90B9-7F123D2BE411

\section{Type species}

Nyfrieslandoceras bassleroceroides gen. et sp. nov.

\section{Diagnosis}

Slightly curved slender conch with compressed conch cross section; ornamented with distinct irregularly spaced growth lines, which form hyponomic sinus at convex side of conch curvature; chambers are narrowly spaced, ca nine per distance similar to corresponding conch height; sutures form broad lateral lobe; siphuncle thin and nearly marginal at convex side of conch curvature, with slightly expanded segments; septal necks short, thickened achoanitic.

Nyfrieslandoceras bassleroceroides gen. et sp. nov. urn:1sid:zoobank.org:act:9E26DE1D-597E-4248-BC5C-6CB9461B66D2

Figs 8D, 45A-B, 49B-C

\section{Diagnosis}

As for genus, by monotypy.

\section{Etymology}

Referring to Bassleroceras Ulrich \& Foerste, 1936 because of its superficial similarity with this genus.

\section{Type material}

\section{Holotype}

Specimen FMNH-P30353.

Paratype

Specimen FMNH-P30356 from type horizon and locality. 


\section{Type locality and horizon}

From Profilstranda section, Ny Friesland, Spitsbergen, bed PO 131, $128 \mathrm{~m}$ above base of Olenidsletta Member, $\mathrm{V}_{2 \mathrm{~b}}$ trilobite zone, Blackhillsian, Floian.

\section{Description}

The type specimen is a $62 \mathrm{~mm}$ long fragment of a phragmocone and a complete body chamber (Fig. 45AB). The conch is slightly curved with a marginal siphuncle on the convex side of the conch curvature. The preserved portion of the phragmocone has a height of $13-18 \mathrm{~mm}$ and a width of $11-13 \mathrm{~mm}\left(9^{\circ}\right.$ angle of expansion of conch height). The body chamber is simple tubular, $30 \mathrm{~mm}$ long and has a height of 18-20 mm and a width of 13-14 $\mathrm{mm}$ ( $4^{\circ}$ angle of expansion of conch height). The body chamber is moderately compressed (with ratio conch width /conch height ca 0.7 ), but the more adapical parts of the fragment are less compressed $(\mathrm{rW} \approx 0.85)$.

The conch surface is ornamented with prominent irregularly spaced growth lines which form a distinct hyponomic sinus on the convex, prosiphuncular side of the conch curvature.

The siphuncle is thin ( $\mathrm{rSD}=1 / 16)$, nearly marginal, and slightly expanded within the chambers. The septal necks are thickened and very short orthochoanitic or achoanitic (Figs 8D, 49B-C). The sutures are obliquely transverse, form wide lateral lobes and bent forward on the convex side of the shell. Approximately nine chambers occur per length similar to the corresponding conch height at the base of the body chamber. The chamber length is $2 \mathrm{~mm}$ at a conch height of $18 \mathrm{~mm}$. Cameral and/or endosiphuncular deposits not known.

\section{Comparison}

This species is externally similar to a slender Bassleroceras Ulrich \& Foerste, 1936, but differs in having an expanded siphuncle with peculiar, very short or achoanitic, thickened septal necks, known otherwise only from Richardsonceras Foerste, 1933 and Richardsonoceroides Chen, 1987. The former genus is
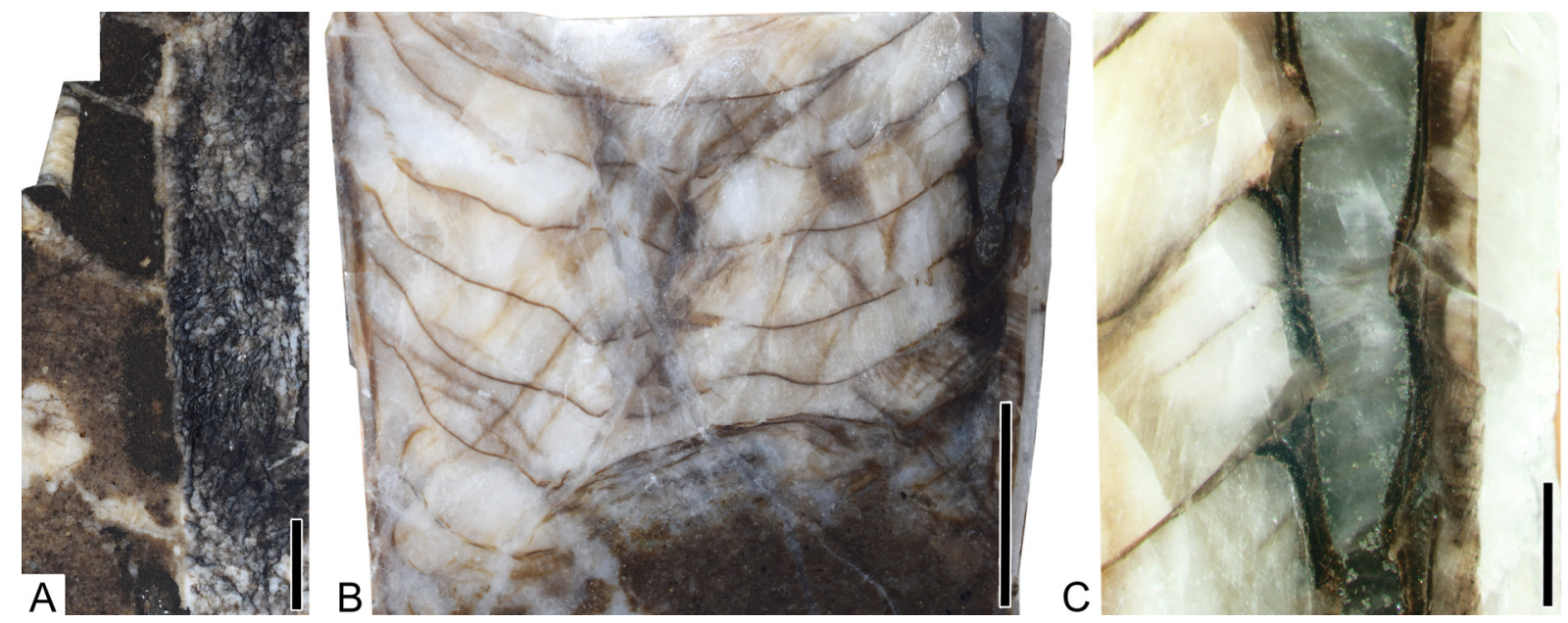

Fig. 49. Median sections of phragmocones of cephalopods from the Olenidsletta Member, Floian, Ordovician, Profilstranda section, Ny Friesland, Spitsbergen. A. Order, gen. et sp. indet. B, FMNH-P30424, from bed 4.8, see also Fig. 11A for interpretation. B-C. Nyfrieslandoceras bassleroceroides gen. et sp. nov., FMNH-P30353, holotype, from bed PO 131. B. Detail with septa and siphuncle preserved, septa are crushed and taphonomically distorted. C. Detail of septal necks and connecting ring, see Fig. 8D for interpretation. Scale bars: $A-B=5 \mathrm{~mm} ; \mathrm{C}=1 \mathrm{~mm}$. 
strongly curved and has a contracted adult body chamber. The latter genus is less compressed, smaller and more curved. Nyfrieslandoceras bassleroceroides gen. et sp. nov. can be conveniently classified within the Phthanoncoceratidae because of its combination of characteristic septal necks, nearly tubular siphuncle and exogastric conch curvature.

Genus Olenidslettoceras gen. nov.

urn:1sid:zoobank.org:act:D66D41DD-0A41-4110-BFF7-1E014ED180FA

\section{Type species}

Olenidslettoceras farmi gen. et sp. nov., from $120.3 \mathrm{~m}$ (PO 123.3) above base of Olenidsletta Member, V2a trilobite zone, Blackhillsian, Floian by original designation.

\section{Diagnosis}

Slender, depressed, exogastric cyrtocones. Angle of expansion larger in apical portions. Adoral portions of mature specimens less curved and with low angle of expansion. Chambers narrowly spaced. Thin siphuncle positioned near conch margin at convex side with thick connecting rings which are tubular at the dorsal side and concave at the ventral side. Septal necks are very short, thickened, and orthochoanitic to suborthochoanitic.

\section{Comparison}

See discussion of type species.

Olenidslettoceras farmi gen. et sp. nov.

urn:1sid:zoobank.org:act:8AE46041-CAE1-4ABB-8082-A21AD56CB9E5

Figs $5 \mathrm{~F}-\mathrm{G}, 6 \mathrm{D}, 8 \mathrm{C}, 50 \mathrm{~A}$

\section{Diagnosis}

As for genus, by monotypy.

\section{Etymology}

Referring to M/S Farm, the transport vessel of Henningsen Transport \& Guiding A/S that brought the specimen back from Profilstranda to Longyearbyen; Spitsbergen.

\section{Type material}

\section{Holotype}

Specimen FMNH-P30380.

\section{Paratype}

One additional specimen, FMNH-P30345, from type horizon and locality.

\section{Type locality and horizon}

From Profilstranda section, adjacent to Hinlopenstretet, Spitsbergen, bed PO 123.3, $120.3 \mathrm{~m}$ above base of Olenidsletta Member, $\mathrm{V}_{2 \mathrm{a}}$ trilobite zone, Blackhillsian, Floian

\section{Description}

The holotype is a $47 \mathrm{~mm}$ long fragment of a phragmocone with part of the body chamber preserved (Fig. 5F-G). The conch is exogastrically curved, more so in the apical parts of the specimen. The preserved part of the body chamber is ca $15 \mathrm{~mm}$ long. The conch cross section is elliptically depressed, it grows in width from $9.5 \mathrm{~mm}$ to $14 \mathrm{~mm}$ and in height from $7.6 \mathrm{~mm}$ to $10.8 \mathrm{~mm}$ at a length of $36 \mathrm{~mm}$ 
(expansion of width $7^{\circ}$, of height $5^{\circ}, \mathrm{rW} \approx 1.3$ ). The surface of the holotype is relatively poorly preserved but is presumed originally smooth, with weak growth lines.

The second specimen has a well-preserved conch surface and shows weak growth lines which run directly transverse and form a shallow and wide sinus at the antisiphuncular side of the conch. The second specimen is a fragment of a phragmocone, which grows in width from 8.7 to $11 \mathrm{~mm}$ and in height from $7.2 \mathrm{~mm}$ to $9.2 \mathrm{~mm}$ (expansion of width $11^{\circ}$, and height $9^{\circ}$ ) at a length of $13 \mathrm{~mm}$. The corresponding $\mathrm{rW}$ is 1.21 and 1.19 , respectively.

The chamber spacing is narrow, seven to ten chambers occur at a distance similar to the conch height. The siphuncle is close to the conch margin, has thick connecting rings which are tubular at the dorsal side (the side directed toward the conch center) and concave at the ventral side (Fig. 6D). The septal necks are short, thickened and orthochoanitic to suborthochoanitic (Figs 8C, 50A).

\section{Remarks}

The curvature of the conch of this species is relatively weak compared with the other cyrtocones from the Olenidsletta Member (e.g., Lawrenceoceras larus sp. nov., Valhalloceras floweri). The species can be distinguished from the superficially similar Valhalloceras floweri by its weaker curvature and
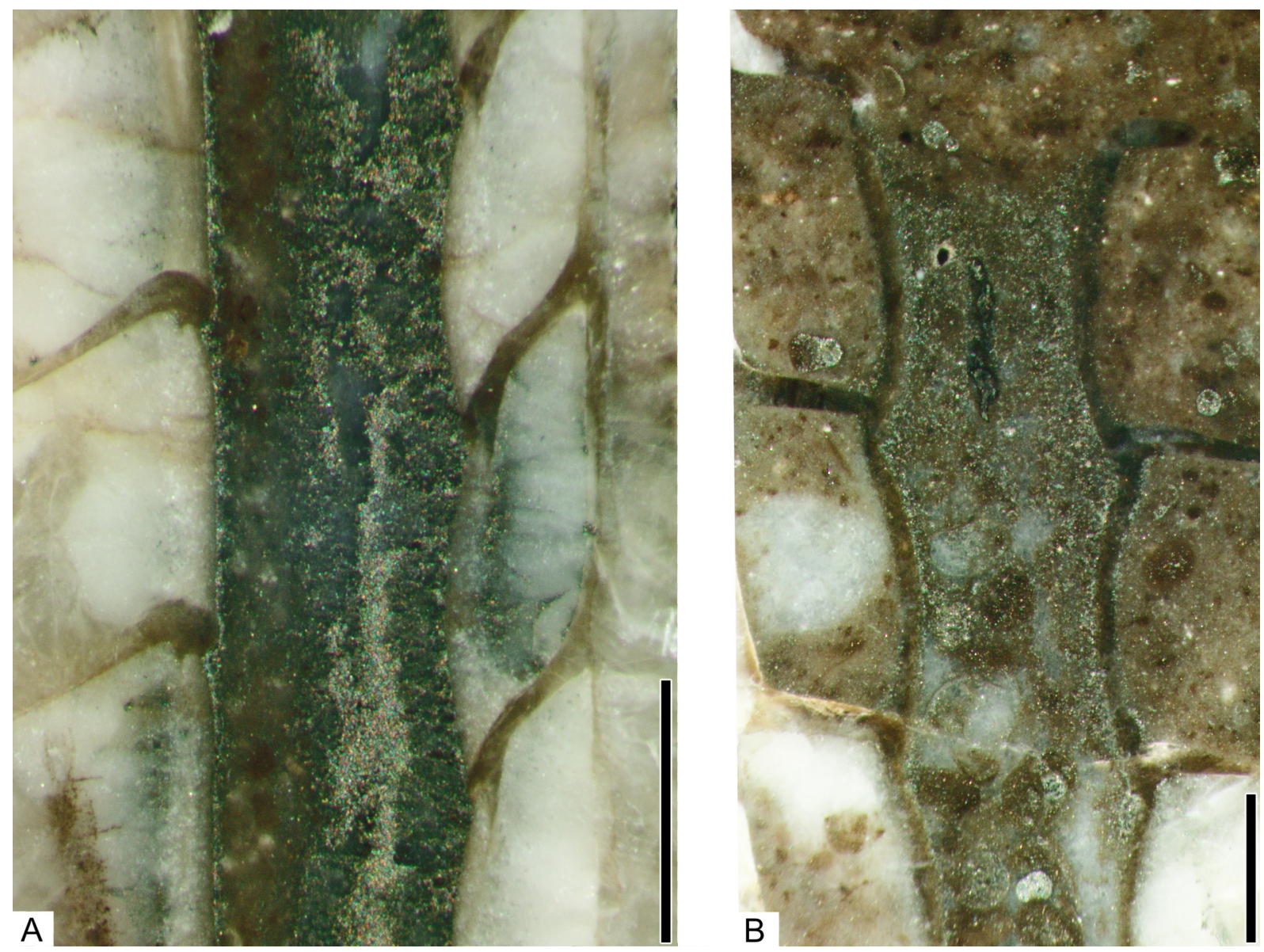

Fig. 50. Median sections of phragmocones of oncocerids from the Olenidsletta Member, Floian, Ordovician, Profilstranda section, Ny Friesland, Spitsbergen. A. Olenidslettoceras farmi gen. et sp. nov., FMNH-P30334, holotype, from bed PO 123.3, see Fig. 8C for interpretation. B. Vallhalloceras floweri Evans \& King, 1990, FMNH-P30340, see Fig. 8B for interpretation. Scale bars $=1 \mathrm{~mm}$ for both figures. 
relatively low angle of expansion. The septal necks are very similar to the necks of Middle Ordovician species of Richardsonoceroides and Richardsonoceras (see Kröger et al. 2009b: fig. 9.10-11). The new genus differs from Richardsonoceroides in having a depressed conch cross section and siphuncular segments with a concave ventral and tubular dorsal shape. Olenidslettoceras farmi gen. et sp. nov. is provisionally placed within the Phtanoncoceratidae because of its combination of characteristic septal necks, the presence of a partly tubular siphuncle and exogastric conch curvature.

Genus Valhalloceras Evans \& King, 1990

\section{Type species}

Valhalloceras floweri Evans \& King, 1990 from the Olenidsletta Member, Blackhillsian, Floian; by original designation.

\section{Diagnosis}

Small exogastrically curved conch with subtriangular conch cross section, venter obtusely rounded; lateral sides more acutely curved, and dorsum broadly rounded; siphuncle narrow, subventral with orthochoanitic septal necks; connecting rings thickened and differentiated; siphonal diaphragms present; sutures form weak dorsal and ventral lobes with lateral saddles; shell surface smooth with weak sinus over venter (from Evans \& King 1990).

\section{Remarks}

Evans \& King (1990) placed this genus within the Phthanoncoceratidae. However, the type species of this family, Phthanoncoceras oelandense Evans \& King, 1990, has strongly concave siphuncular segments, thickened connecting rings and relatively long, loxochoanitic septal necks, which is in contrast to the orthochoanitic necks and nearly tubular connecting rings known from Valhalloceras. Therefore, Valhalloceras would by definition be better placed within the Graciloceratidae (see Sweet 1964 for the diagnosis of the Graciloceratidae). However, this placing is ambiguous too, because the figured features of the connecting ring and septal necks of the type specimen of Valhalloceras are from relatively small apical parts of the phragmocone, with details of the connecting ring and septa of later growth stages either not, or poorly, preserved (see Evans \& King 1990: pl. 1 figs 8, 10-11). The few specimens of Valhalloceras present in our collection suggest that in parts of the phragmocone from later ontogenetic growth stages the connecting rings are thick and concave (see below). If this is the case (David Evans, pers. com., agrees with this opinion) and the connecting rings in Valhalloceras are concave during later growth stages, the species is intermediate among Oncoceratida, such as graciloceratids with tubular rings and bassleroceratids with concave rings. Hence, Valhalloceras compares closely to Proterocameroceras valhallfonnense sp. nov. with its ambiguous connecting ring shape, a species that is morphologicallly transitional between bassleroceratids, such as Lawrenceoceras, and oncocerids, such as Richardsonoceras Foerste, 1933.

Valhalloceras floweri Evans \& King, 1990

Figs $5 \mathrm{H}-\mathrm{N}, 6 \mathrm{C}, 8 \mathrm{~B}, 50 \mathrm{~B}$

Valhalloceras floweri Evans \& King, 1990: 628-629, pl. 1 figs 5-11, text-fig. 3.

\section{Diagnosis}

As for genus, by monotypy. 


\section{Material examined}

Specimen FMNH-P30343 from Profilstranda section, adjacent to Hinlopenstretet, Spitsbergen, bed PO 123.3, $120.3 \mathrm{~m}$ above base of Olenidsletta Member, V2a trilobite zone, and specimens FMNH-P30340, P30346, P30348, and P30350 from bed PO 131, $128 \mathrm{~m}$ above base of Olenidsletta Member, V2b trilobite zone, Blackhillsian, Floian.

\section{Description}

Specimen FMNH-P30343 is the externally most complete specimen (Fig. 5H-I). It is a slightly crushed curved conch with a length of more than $30 \mathrm{~mm}$ which grows from $7.3 \mathrm{~mm}$ in height and $9.5 \mathrm{~mm}$ in width to $10 \mathrm{~mm}$ in height and $14 \mathrm{~mm}$ in width at a length of $15 \mathrm{~mm}$ (width expands with $17^{\circ}$, height with $10^{\circ}$ ). The cross section is depressed (rW: 1.3-1.5) and nearly elliptical at the adapical end of the specimen. The surface is ornamented with irregularly spaced fine growth lines, which run almost transversally at the ventral side and form a shallow broad sinus at the dorsal side. The internal characters of specimen FMNH-P30343 are not preserved. Three specimens with similar relative conch shape (rW: 1.3-1.6) occur in bed PO 131 and are better preserved internally. In specimen FMNH-P30340 from bed PO 131 at the Profilstranda section, the septal necks are orthochoanitic and the connecting rings are thickened and concave (figs 6C, 50B). The septal perforation is $1.7 \mathrm{~mm}$ in diameter and the connecting ring at approximately midlength between two chambers is $1.4 \mathrm{~mm}$ in diameter $(0.11-0.14$ of corresponding conch height). Approximately six chambers occur at a distance similar to the corresponding conch height.

\section{Remarks}

The type specimen of this species comes from a coastal outcrop between Lundehuken and Papegoyneset, adjacent to Hinlopenstretet, from a level near the top of $V_{2}$ in the terminology of Fortey (1980) (see Evans \& King 1990). This is only a few kilometers south of the Profilstranda section, and at a level almost identical to beds PO 131, where the majority of our specimens of $V$. floweri were collected (see Fig. 1). Evans \& King (1990) described and discussed Valhalloceras floweri in detail based on a single specimen, which expands laterally with an angle of $12^{\circ}$ and dorsally with an angle of $19^{\circ}$, and which has a relative conch width (rW) of 1.4. Both values are closely similar to the specimens described herein. The specimens are also almost identical in conch cross section shape, conch curvature, in relative septal spacing and in the shape of the septal necks. However, the only available median section from specimens from our collection shows a siphuncle with contracted segments. This difference can be an effect of different preservation. In the type specimen, the septa and partly the connecting rings are strongly recrystallized and partly only traces of the former outlines are preserved (Evans \& King 1990: pl. 1 figs 8, 10-11). Alternatively, the difference can be true and reflect different growth stages and ontogenetic change, because the figured siphuncle in the type is from a corresponding conch height of ca $7 \mathrm{~mm}$, compared with the specimen figured herein (Fig. 50B) with a corresponding conch height of ca $14 \mathrm{~mm}$. Depending on the interpretation of the differences, the genus Valhalloceras has tubular to concave or exclusively concave segments, respectively. In the former interpretation the genus would be transitional between Oncocerida and Ellesmerocerida and in the latter it would be a bassleroceratid, similar to Lawrenceoceras, but with orthochoanitic, instead of loxochoanitic septal necks. More material is needed to definitively solve this problem. Here we place the genus provisionally within the Phthanoncoceratidae, because the presence of tubular connecting rings during early growth stages is assumed to be real.

Order, gen. et sp. indet. A

Fig. 45C-D

\section{Material examined}

Specimen FMNH-P30354, from Profilstranda section, Ny Friesland, Spitsbergen, bed PO 131, $128 \mathrm{~m}$ above base of Olenidsletta Member, V2b trilobite zone, Blackhillsian, Floian. 


\section{Description}

Specimen FMNH-P30354 is a $30 \mathrm{~mm}$ long fragment of a phragmocone and part of a body chamber. The preserved part of the body chamber is $14 \mathrm{~mm}$ long and has a compressed conch cross section with $\mathrm{rW}=0.9$ at a height of $10 \mathrm{~mm}$. The angle of expansion is not known with precision, but the conch is longiconic and its width grows less than $1 \mathrm{~mm}$ at the preserved length of $30 \mathrm{~mm}$. The shell surface is smooth. The conch is nearly orthoconic or slightly curved with the siphuncle presumably near or at the conch margin. The direction of conch curvature is difficult to determine, because the specimen is slightly distorted taphonomically, but presumably the siphuncle is at the concave side of the conch curvature. The sutures are obliquely transverse and bent forward on the convex side of the shell. Approximately five to six chambers occur per length similar to the corresponding conch height. The chamber length is $1.8 \mathrm{~mm}$ at a conch height of $9.5 \mathrm{~mm}$ ( 0.19 of corresponding conch width).

\section{Remarks}

This specimen is relatively well preserved externally, but the position of the siphuncle, its shape and the shape of the septal necks are unknown, which precludes any further determination. Based on the relatively narrow septal spacing and the almost straight slender conch form, the specimen is either a fragment of a bassleroceratid or a proterocameroceratid.

Order, gen. et sp. indet. B

Figs 11A, 45G, 49A

\section{Material examined}

Specimen FMNH-P30424, from Profilstranda section, Ny Friesland, Spitsbergen, bed PO 4.8, $1.8 \mathrm{~m}$ above base of Olenidsletta Member, V1a trilobite zone, Blackhillsian, Floian.

\section{Description}

The specimen is a relatively well-preserved fragment representing a weakly exogastrically curved slender phragmocone with a length of $72 \mathrm{~mm}$ and a conch height of 17-23 mm (Fig. 45G). Only the left part of the conch is preserved. Based on the preserved position of the siphuncle, the conch width can be reconstructed: the reconstructed width is ca $18-28 \mathrm{~mm}$ at either end of the preserved portion. The conch cross section, hence, is slightly compressed.

The surface is ornamented with distinct, straight, transverse, rounded lirae (ca six per mm at the adapical end of the specimen) and irregularly spaced growth lines. Additionally, the conch is very weakly and irregularly undulated with a distance between two subsequent undulations between 3 and $5 \mathrm{~mm}$. The ornamentation is slightly oblique, shifted toward the aperture at the antisiphuncular side of the conch.

At the adoral end of the specimen the chamber distance is $7 \mathrm{~mm}$. The septal perforation has a diameter of ca $7 \mathrm{~mm}$ at the adoral end of the specimen $(\mathrm{rSD}=0.4)$ and is eccentrically positioned, with a distance of the siphuncle of ca $3 \mathrm{~mm}$ from the conch margin. The septal necks are long orthochoanitic to hemichoanitic and the shape of the connecting ring was presumably tubular or nearly so (Figs 11A, 49A).

\section{Remarks}

Given the high number of longiconic orthocones with a relatively wide subcentral, tubular siphuncle and orthochoanitic septal necks within the Baltoceratidae, Troedssonellidae, and Proterocameroceratidae in Floian and Dapingian strata, a high-level classification of this specimen is not possible until more material is available. The relatively long septal necks of this specimen are similar to those of Hemichoanella, but the siphuncle is marginal in the latter genus. More material is needed, specifically to evaluate the presence or absence of endosiphunular deposits in apical portions of the shell. 


\section{Discussion}

\section{Cladistic analysis - Odd mosaics of endocerid-like, orthocerid-like and oncocerid-like cephalopods}

Early Palaeozoic cephalopods may be relatively conveniently classified within a number of distinct orders possessing contrasting combinations of internal and external characters (Teichert et al. 1964; King \& Evans 2019). Taxonomic grouping is more difficult when Floian, particularly late Floian, cephalopod assemblages are compared. The seemingly 'accidental' combinations of features within Floian cephalopod genera, which are otherwise constrained to specific orders, have already been emphasized for the assemblages of the Emanuel Creek Formation, Western Australia (Teichert \& Glenister 1954: 171-172). In the Emanuel Creek faunas, long septal necks - a feature characteristic of the Endocerida, which invariably possess very wide siphuncles - exist in combination with both wide and narrow siphuncles, while orthochoanitic and loxochoanitic septal necks occur in forms with thick or thin connecting rings as well as annulated or smooth shells. Several cephalopods of the Olenidsletta Member also have odd trait combinations, which are difficult to place in the existing classification scheme.

A cladistic analysis, performed with a number of relevant taxa, helps to find ideally monophyletic taxonomic groups and to frame explicit phylogenetic relationships among them. Herein, four separate analyses have been conducted to test different a priori interpretations and hypotheses (Fig. 51). In some species it is challenging to differentiate between tubular and concave siphuncular segments. Therefore, two different character matrices have been used for each interpretation. Additionally, the analyses have been constrained by assuming that the Endocerida, Oncocerida, and Orthocerida are monophyletic (see Methods).

Each of the four analyses resulted in a single most parsimonious tree, respectively (Fig. 51A-D). One tree was plotted against the stratigraphy (Fig. 52). The retained clades were roughly similar to established families and orders, although there exist large differences in their basal relationships. The consistency and retention indices had a narrow range, with the CI ranging from 0.269 to 0.279 and a RI between 0.535 and 0.545 . These indices indicate a relatively high level of homoplasy. This is not surprising, because of the presence of continuous as well as other characters, that relate mainly to shape and only a few characters represent new evolutionary innovations. Bremer support and bootstrap frequencies are relatively low throughout the cladogram, although they tend to be slightly higher in more nested nodes. Nevertheless, this is common for many morphological datasets and the results presented herein do not present wildly new hypotheses that contradict current understanding of Palaeozoic cephalopod evolution. Therefore, although they are relevant and provide new insights, the trees should not be read too literally, as additional taxa may significantly alter the phylogenetic reconstructions.

The Ellesmocerida Flower, 1950 are composed of paraphyletic species. This is expected as they are considered to be ancestral to most other Ordovician groups (Flower \& Kummel 1950; Dzik 1984; Wade 1988). This situation is difficult to resolve because many ellesmerocerids are poorly known and relatively similar to each other, so that only a few additional steps are required to support an alternative tree topology. Nevertheless, the genera Robsonoceras Ulrich \& Foerste, 1933, Rudolfoceras Ulrich et al., 1944, and Eorudolfoceras Kröger \& Landing, 2007 are consistently recovered close to the base of the tree, near the outgroup Ectenolites Ulrich \& Foerste, 1935. In fact, since the outgroup has no effect on the number of steps, one could re-root the tree so that these four genera, all of which are typically classified within the Ellesmeroceratidae Kobayashi, 1934, would be monophyletic in the unconstrained analyses (Fig. 51A, C). In the constrained analyses (Fig. 51B, D), the ellesmeroceratids are still close to the base of the tree, but not sequential as before, since the enforced monophyly of the Oncocerida has the effect of moving the bassleroceratids close to the base of the tree. The Bassleroceratidae are represented herein by two 


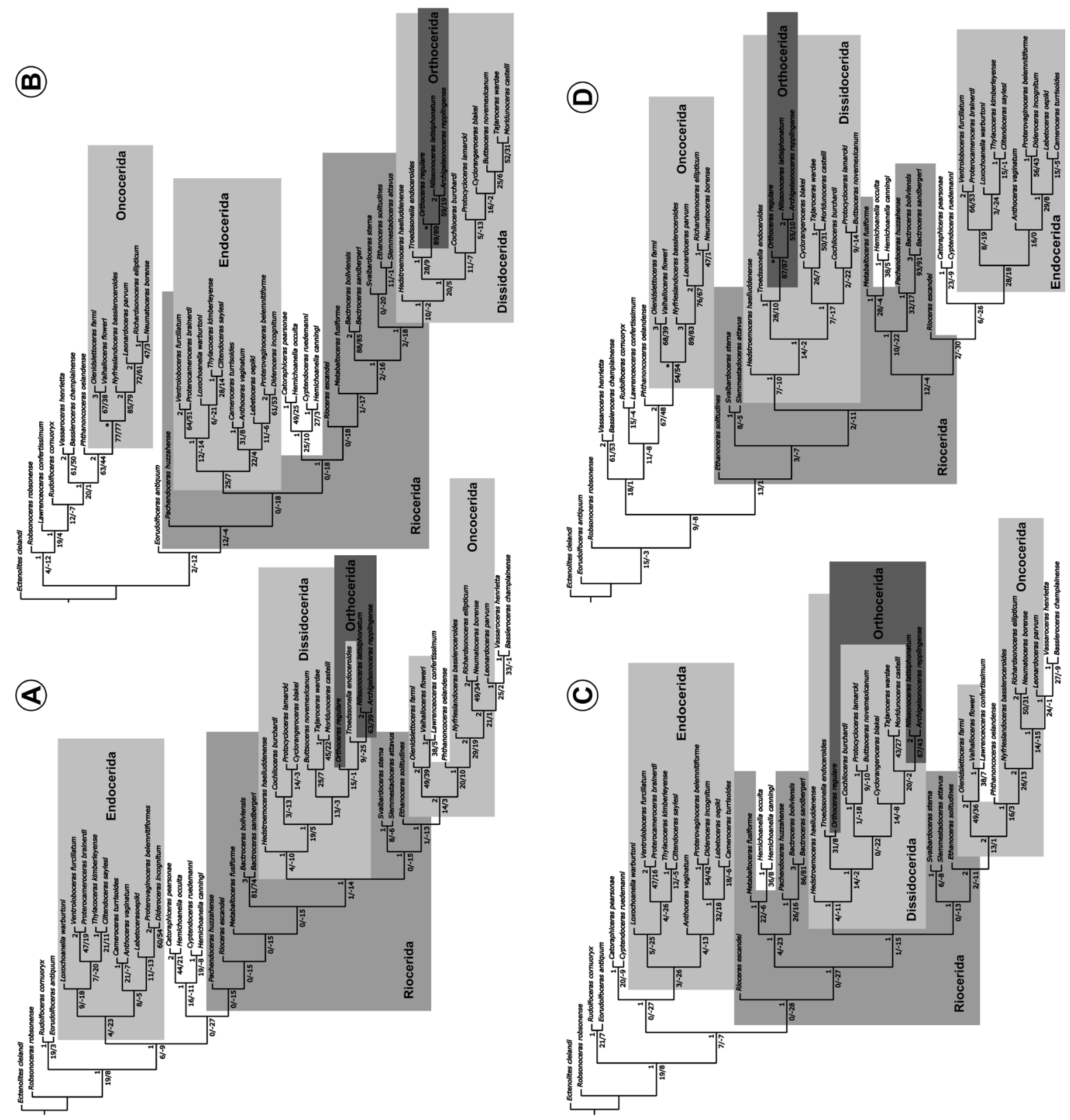

Fig. 51. Single most parsimonious trees of four separate cladistic analyses to test different a priori interpretations and hypotheses. A-B. Shape of siphuncular segments of critical species interpreted as "tubular". C-D. Shape of siphuncular segments of critical species interpreted as "concave". B-D. Analyses with several topological constraints enforced under an assumption of the monophyly of the Endocerida, Oncocerida, and Orthocerida (see methods for details). Critical species are: Ethanoceras solitudines sp. nov., Olenidslettoceras farmi gen. et sp. nov., Svalbardoceras sterna gen. et sp. nov., and Valhalloceras floweri Evans \& King, 1990. Grey boxes indicate established order level classification of species in the analysis. Values above branches are Bremer supports (if $>1$ ), values below branches are bootstrap supports (absolute and GC frequencies). 
genera: Bassleroceras and Lawrenceoceras. Curiously, although both are recovered within the larger oncocerid clade (unconstrained) or near its base (constrained), they are never recovered as monophyletic or sequential to each other. This is possibly a result of using Lawrenceoceras confertissimum here, which differs from typical bassleroceratids in possessing straight sutures with slight ventral and dorsal lobes instead of only lateral lobes. In any case, it is interesting that the Stairsian genus Vassaroceras Ulrich et al., 1944 is always recovered as sister taxon to Bassleroceras, in the case of the constrained analyses. The classification of Vassaroceras has been unclear in the past (Kröger \& Landing 2008), but the results here might suggest that it could be classified within the Bassleroceratidae. Consequently, our analyses show no support for the monophyly of this family, even if Vassaroceras were to be included, but the constrained analyses support a paraphyletic group ancestral to the Oncocerida that includes besides the bassleroceratids, the exogastric Rudolfoceras and Phthanoncoceras Evans \& King, 1990. The position of Bassleroceras and Vassaroceras deep within the Oncocerida as suggested by the unconstrained analyses can be rejected because it directly contradicts the stratigraphic sequence of appearance. Therefore, the Bassleroceratidae are here confirmed as ancestral group of the Oncocerida, as presumed earlier (Flower \& Kummel 1950). If the results obtained here are confirmed by future studies, the group may be emended to include Rudolfoceras and Vassaroceras as well. The Phthanoncoceratidae was established by Evans \& King (1990), but Kröger et al. (2009b) placed the type genus in the Ellesmerocerida and the second genus Valhalloceras in the Oncocerida. While our results do not support the monophyly of the Phthanoncoceratidae, the two genera, together with Nyfrieslandoceras gen. nov. and Olenidslettoceras gen. nov., are relatively closely related and ancestral to oncocerids. It is therefore possible to resurrect the Phthanoncoceratidae as basal oncocerids that include these four genera, which differ from the Graciloceratidae in having concave siphuncular segments. This approach is followed herein. The last group of ellesmerocerids is represented by Hemichoanella, Catoraphiceras and Cyptendoceras. None of our analyses recovered these genera as closely related to other ellesmerocerids. The two species of Hemichoanella were recovered as paraphyletic by the analyses with the tubular interpretation of the connecting ring, while they represent a monophyletic clade in the concave interpretation. While this may question the assignment of Hemichoanella occulta sp. nov. to this genus and suggest an alternative classification as Catoraphiceras, we think that in this case the concave interpretation is more realistic, and the close association between $H$. occulta sp. nov. and Catoraphiceras pearsonae Hook \& Flower, 1977 is likely driven by similarities in external conch shape. The four species had differing phylogenetic positions in each of the analyses, which makes their classification challenging. However, it also shows that the Protocycloceratidae are likely polyphyletic and should be abandoned or used in a more restricted concept. Here, the Protocycloceratidae are therefore not used. Instead, the Cyptendoceratidae are here shown to be independently derived, and possibly Catoraphiceras and Hemichoanella belong to this group as well. It is somewhat puzzling that no tree recovered Catoraphiceras and Cyptendoceras within the Dissidocerida, which would suggest that rods and cameral deposits evolved at least twice independently. It is also possible that additional taxa would resolve these two taxa closer to the base of that order. Here, presence of these two characters is regarded as highly relevant and the Cyptendoceratidae are provisionally placed within the Dissidocerida. Hemichoanella is difficult to place with the available information. If endocones, endosiphuncular deposits and cameral deposits are truly absent, it would suggest a potential relationship to the Riocerida.

The Endocerida consistently formed a monohyletic clade in all conducted analyses, albeit with low support. Its position varied from a sister clade to all remaining non-Ellesmeroceratidae to derived from within the Riocerida. It is therefore impossible to draw conclusions on the origin of the Endocerida here. The genera Lebetoceras Teichert \& Glenister, 1954, Loxochoanella Teichert \& Glenister, 1954 and Ventroloboceras Teichert \& Glenister, 1954 were consistently recovered within the endocerid clade, thus supporting their transfer from the Ellesmerocerida to a yet to be determined family of the Endocerida. The exact assignment is hampered in that endocones are unknown in these taxa. More research is needed to clarify whether the known material represents juvenile stages without endocones being developed, 
or whether they represent relics of ancestral endocerids prior to the evolution of endocones or the secondary loss of endocones. Note also that none of our analyses recovered Hemichoanella within the Endocerida. Internally, endocerids were consistently divided into two weakly supported sister clades, which seem to correlate with their stratigraphic position. With the exception of Lebetoceras, all Early Ordovician (possible) endocerids were assigned to one clade, most notably Thylacoceras Teichert \& Glenister, 1952 and Proterocameroceras. The remaining endocerids in the sister clade range from the Darriwilian to the Katian, in addition to the Floian Lebetoceras. Whether these relationships within the Endocerida are representative remains doubtful, because characters describing the internal structures of endocones are not included here. These structures are considered important for endocerid classification (Flower 1955). In addition, the taxon sampling is not representative for the entire endocerid clade and several major lineages are missing which could potentially alter the phylogenetic reconstructions (see Evans \& King 2012).

The Dissidocerida and the Orthocerida are corroborated by the analyses as a monophyletic clade containing both orders, although the former was always recovered as paraphyletic and the latter as polyphyletic when unconstrained. An origin of the Orthocerida from the Dissidocerida has been suggested previously (Zhuravleva 1994), and thus the paraphyly of the Dissidocerida is not surprising. The sample of the Orthocerida is relatively small and homeoplasy in external shell shape may explain its polyphyly. Alternatively, Troedssonella may be transferred to the Orthocerida, suggesting complex evolutionary patterns of endosiphuncular deposits. However, this would render the Troedssonellidae polyphyletic, as it also contains Buttsoceras, Moridunoceras and Tajaroceras. The DissidoceridaOrthocerida clade originates in all analyses from within the Riocerida, which supports the classification of the Orthoceratoidea (or Orthoceratia) as envisioned by King \& Evans (2019), ignoring the uncertain origin of the Endocerida. However, all analyses recovered the Riocerida as paraphyletic, additionally giving rise to the Oncocerida (unconstrained analyses) or the Endocerida (constrained). Furthermore, several topologies were recovered where genera previously classified within the Ellesmerocerida fell into a subclade of the Riocerida (see above). Relationships within the Riocerida were quite unstable between analyses and generally, except for the sister group relationship between the two species of Bactroceras, with very low bootstrap frequencies. Remarkably, despite the presence of endosiphuncular linings in B. boliviensis, the analyses do not show a close relationship between Bactroceras and dissidocerids which contain deposits. This may suggest either that 1) the trait evolved twice independently or 2) the phylogenetic trees are biased. While 2) is certainly the case at least to some degree, a more thorough species sampling combined with a better understanding of the formation and evolution of endosiphuncular deposits would help immensely in improving the definitions of character state transitions. There is no clear link between Bactroceras and Middle Ordovician orthocerids with endosiphuncular deposits. The deposits of the latter are mostly restricted to the septal necks (annuli) and their siphuncle is central. It is therefore more parsimonious to derive these taxa from dissidocerids, which already had central siphuncles and a combination of linings and annuli, which is also supported by our analyses.

The Oncocerida were recovered as paraphyletic in the unconstrained analyses, which is mainly caused by the nested position occupied by the Bassleroceratidae (see above). Constraining the Oncocerida to be monophyletic results in the expected ancestral position of the Bassleroceratidae. The intra-oncocerid relationships are consistent with their stratigraphic record, especially in the constrained analysis for the concave interpretation (Fig. 52). This is also true for their ancestral lineage, where Bassleroceras and Vassaroceras are the oldest members and recovered as sister group to the rest of the the clade, followed by Rudolfoceras and Lawrenceoceras. The oldest members of the Oncocerida, the late Floian Olenidslettoceras gen. nov., Valhalloceras and Nyfrieslandoceras gen. nov. are also closely related, while the Middle Ordovician oncocerids were recovered as a monophyletic clade. The only exception to this pattern is the Darriwilian Phthanoncoceras, which was recovered as sister group to the constrained monophyletic Oncocerida. 
In summary, it becomes clear that additional phylogenetic analyses are needed to clarify the picture of the early radiation of orthoconic cephalopods. The analyses, conducted herein, confirm some previous hypotheses, but also offer a new perspective for some of the traditionally recognized groups. The Ellesmerocerida has long been recognised as ancestral to many other groups of Ordovician cephalopods and thus as being paraphyletic (e.g., Flower \& Kummel 1950; Dzik 1984). Subsequent removal of several groups from the Ellesmerocerida such as the Baltoceratidae (Kröger \& Evans 2011), Cyrtocerinida (Mutvei 2015) and Rioceratidae (King \& Evans 2019) helped to reduce the scope of the order but did not change its fundamental paraphyly. The analyses, presented herein, confirm the Riocerida as ancestral group of the Orthoceratoidea, but also highlight that it represents a paraphyletic group with at least two independent descendant lineages. Likewise, the Dissidocerida is confirmed as basal to the Orthocerida, which emphasizes the paraphyly of the former group. The Orthocerida are possibly polyphyletic, although adding further taxa potentially resolves this situation. Resolving the systematic classification to a more natural, phylogenetic scheme is challenging because of the ladder-like tree topology. This would leave many of the basal taxa without clear morphological definitions. For now, a pragmatic approach may be best, retaining the Riocerida as ancestral orthoceratoids that mostly lack endosiphuncular and cameral deposits. The division into Rioceratidae with wide siphuncles and the Bactroceratidae with narrow siphuncles may be practical (and is followed herein), although our results question whether this distinction is natural. The Dissidocerida are then defined as orthoceratoids with large siphuncles that may contain diverse combinations of cameral and endosiphuncular deposits, while the Orthocerida are descendants of the latter and possess narrow, more or less central siphuncles.

Furthermore, the analyses presented herein emphasize the problematic nature of some current diagnoses of family or order ranked taxonomic units, as they often do not accurately reflect evolutionary patterns. For example, much emphasis has been put on the concave siphuncle of ellesmerocerids as a definition of that group (e.g., Kröger \& Mutvei 2005). However, since multiple groups originated from this order, the concave shape of the siphuncle was apparently prone to evolutionary transitions. Thus, reversals from tubular or expanded back to concave siphuncular segments represent an explicit possibility that would immediately render the Ellesmerocerida polyphyletic. Having the Ellesmerocerida as an ancestral group to nearly all other early Palaeozoic cephalopods is undesirable in the long run, because it obscures evolutionary relationships between the other clades. Future research should therefore focus on identifying the ancestral 'ellesmerocerid' lineages of other nautiloid groups and broaden the definitions of those groups. Homeomorphy is common in many Palaeozoic cephalopods and presents a serious challenge for the definition of family-rank groups and above. Diagnoses should therefore always allow for some variation. The assignment to taxonomic units should be based on phylogenetic relationships, but at the same time represent a useful assemblage of similar characters. The ultimate goal would be to reach a classification that reflects phylogeny, but also has high stability and utility for specialists and non-experts alike.

In the above discussion, we explicitly excluded the extensive phylogenetic analyses of Pohle et al. (submitted), because they are still unpublished at the time of writing. Because of the different methodology (Bayesian vs Parsimony) and the taxonomic scope, the studies are somewhat difficult to compare. Nevertheless, the analyses presented herein show roughly similar patterns, confirming traditionally recognised orders. Most orthoceratoids and endoceratoids fall within a monophyletic clade, although the Oncocerida are part of the Orthoceratoidea in the unconstrained analyses. Furthermore, our analyses seem to suggest a closer relationship between Orthoceratoidea and Endoceratoidea than Pohle et al. (submitted). However, both differences can be explained by the absence of early representatives of the Multiceratoidea (e.g., Cyrtocerinida, Tarphycerida) in the dataset used herein, as they would perhaps pull oncocerids away from orthoceratoids while also providing a connection between endoceratoids and multiceratoids. The advantage of our analyses here is that they include more riocerid and oncocerid species, confirming the close but paraphyletic relationship between the former and the association 


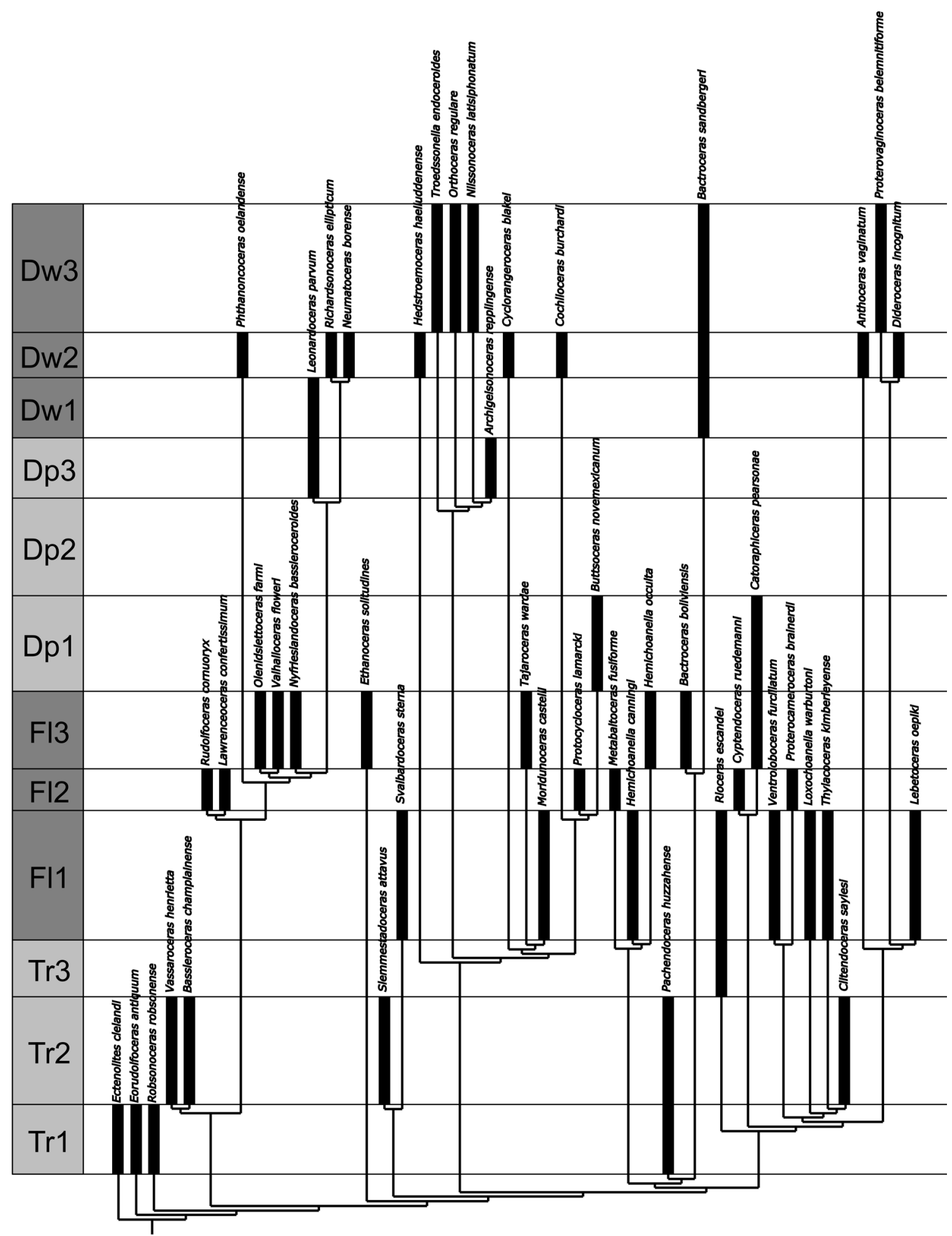

Fig. 52. Single most parsimonious tree resulting from constrained analysis with the "concave" interpretation plotted against stratigraphy. Stratigraphic units (in grey boxes) are Ordovician stage slices after Bergström et al. (2009), modified by Rasmussen et al. (2019). Vertical range of stage slices represents absolute age (after Rasmussen et al. 2019). Abbrevations: $\mathrm{Tr}=$ Tremadocian; $\mathrm{Fl}=$ Floian; $\mathrm{Dp}=$ Dapingian $; \mathrm{Dw}=$ Darriwilian . 
of the latter with bassleroceratids. Note that Pohle et al. (submitted) recover the Ellesmerocerida as polyphyletic, with the Bassleroceratidae nested within the Multiceratoidea clade.

\section{Paleogeographic relations}

One of the more remarkable features of the cephalopod assemblages of the Olenidsletta Member is the high taxonomic distinctiveness of the sampled levels. Bactrites boliviensis is the only species which occurs in all samples and the only species that ranges through divisions $\mathrm{V}_{1}$ and $\mathrm{V}_{2}$. No more than five of the 22 species $(=23 \%)$ sampled from $V_{2}$ are shared between $V_{2 a}$ and $V_{2 b}$ (Fig. 53). The high distinctiveness of the samples results probably from a combination of their relatively large age difference and from the different palaeoecological conditions they represent. The sample horizons of division $\mathrm{V}_{1}$ are within the Oepikodus communis conodont zone and hence were deposited approximately three to four million years prior to the deposition of the horizons within $\mathrm{V}_{2}$, which are within the Isograptus victoriae lunatus graptolite zone (Goldman et al. 2020). Furthermore, the $\mathrm{V}_{2}$ sampling horizons contain a highly diverse nileid trilobite assemblage, which contrasts with the low diversity olenid trilobite assemblage that occurs in the $\mathrm{V}_{1}$ sampling horizons (Fortey 1975a; Fortey \& Barnes 1977). The two trilobite assemblages are interpreted as reflecting communities with different benthic habitat depths and are also recognizable within conodont assemblages (Fortey \& Barnes 1977): the olenid trilobite / Prionodus conodont community has been interpreted as a fauna that lived in relatively deep waters at the outer slope of the shelf, and the nileid trilobite/Periodon conodont community probably inhabited the deep neritic environment of the shelf shoreward from the outer slope (Fortey \& Barnes 1977; Rasmussen \& Stouge 1995; Adrain et al. 2004). High local turnover can also be expected from the repeated change of anoxic/euxinic to oxic bottom conditions during the deposition of the Olenidsletta Member (Lee et al. 2019).

The cephalopod assemblages, although containing nektobenthic and pelagic organisms, reflect the shifts in the trilobite and conodont communities. The cephalopod diversity and evenness is low in the combined sample horizons of $\mathrm{V}_{1}\left(\mathrm{D}_{\mathrm{H} 0}=8, \mathrm{~J}=0.58\right)$ and the diversity is many times higher with a similar evenness in the combined $\mathrm{V}_{2}$ sample horizons $\left(\mathrm{D}_{\mathrm{H} 0}=62, \mathrm{~J}=0.55\right)$ (Fig. 54, see Table 1 for confidence intervals). Cephalopods with a presumed nektobenthic life habit, such as cyrtoconic ellesmerocerids and oncocerids (see, e.g., Hewitt \& Westermann 1996; Peterman et al. 2019) are more diverse and abundant in the $\mathrm{V}_{2}$ sample horizons. Therefore, it can be assumed that the assemblages from $\mathrm{V}_{1}$ are representations of cephalopod faunas from a deeper, more distal, open sea habitat than those of $\mathrm{V}_{2}$.

This interpretation is supported by the results from the septal strength analysis (Table 2, see above) and by the taphonomic differences of the two assemblages, as imploded and heavily recrystallized conchs are much more common in the sampled horizons of $\mathrm{V}_{1}$. These peculiarities of the Olenidsletta Member cephalopod assemblages have to be taken into account when comparing them with contemporaneous assemblages elsewhere.

Cephalopods from the upper O. communis - lower Reuterodontus andinus conodont zone level, middle Floian, have been reported from few regions of the world, most importantly from the Emanuel Formation, stage III of Guppy \& Öpik (1950) of western Australia (see Laurie \& Shergold 1996 for correlation), from the Ogof Hên Formation in Wales, UK (Evans 2005), from the Sciota Member of the Fort Cassin Formation in Vermont, USA (Kröger \& Landing 2009), and from the Croisaphuill Formation in Scotland, UK (Evans 2011). Of the six determinable genera collected from the $\mathrm{V}^{1}$ division of the Olenidsletta Member, three (!) occur in the Fort Cassin Formation (Cyptendoceras, Deltoceras, Protocycloceras). A comparison with the Croisaphuill Formation is complicated by differences in preservation. However, the Olenidsletta Member shares Deltoceras and Protocycloceras lamarcki with the Croisaphuill Formation. The latter is an exceptionally widespread species across eastern Laurentia; it occurs also, e.g., in Vermont, USA (see discussion in Evans 2011). No generic overlap exists with the other regions listed above. 


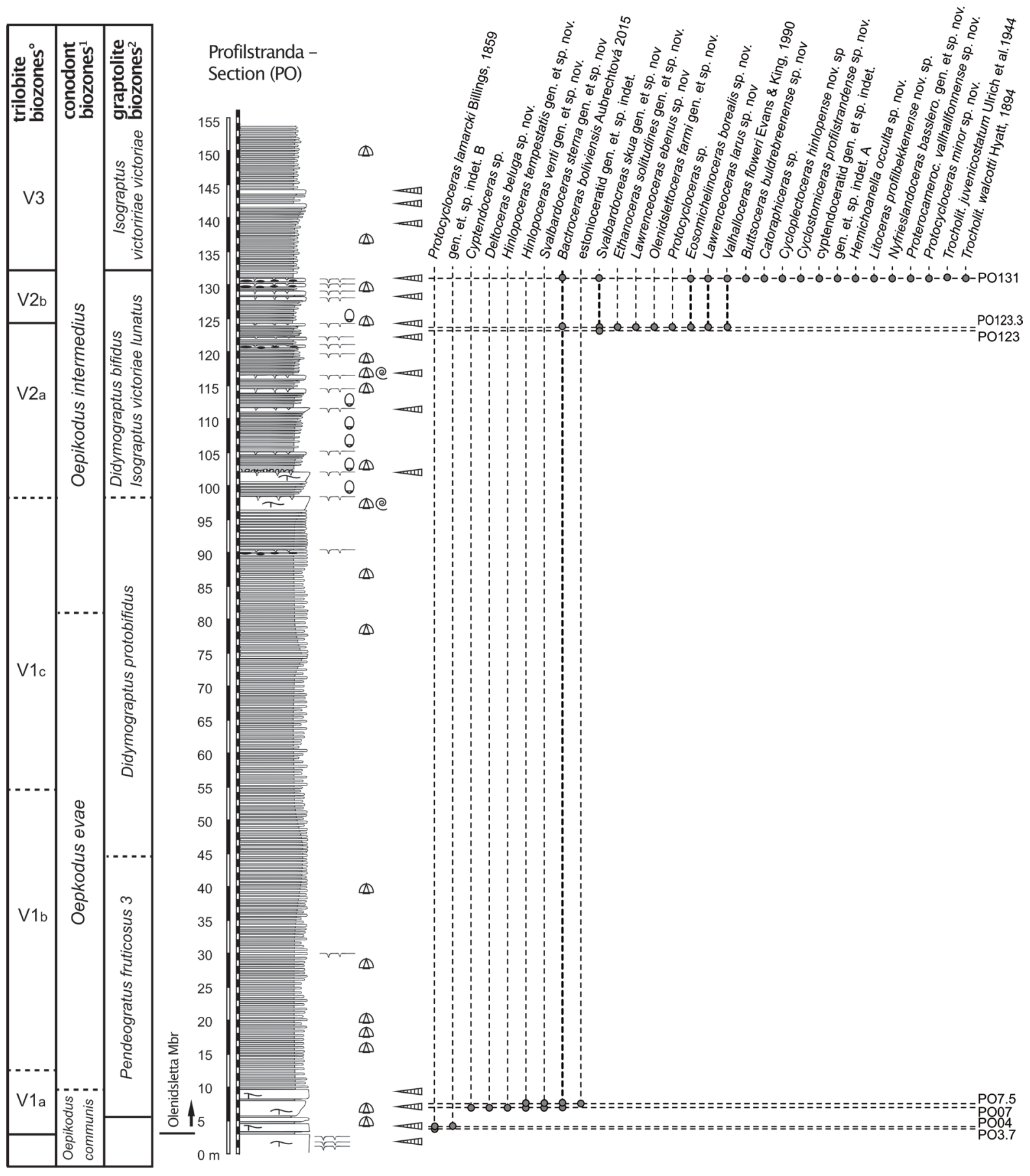

Fig. 53. Cephalopod occurrences in sampled intervals of the Olenidsletta Member, Floian, Ordovician, Profilstranda (PO) section, Ny Friesland, Spitsbergen. ${ }^{0}$ from Fortey (1980), ${ }^{1}$ from Lehnert et al. (2013), ${ }^{2}$ from Cooper \& Fortey (1982). Grey shaded time interval marks nileid trilobite assemblage after Fortey \& Barnes 1977. Section from Kröger et al. (2017). Symbols for organism groups as in Fig. 3. 
Table 1. Diversity $\left(\mathrm{D}_{\mathrm{H} 0}\right)$ and Evenness $(\mathrm{J})$ of stratigraphic intervals of the Olenidsletta Member, Floian, Ordovician of the Profilstranda section, Ny Friesland, Spitsbergen, extrapolated after Hsieh et al. (2016), with $95 \%$ confidence intervals. Abbreviation: $\mathrm{N}=$ number.

\begin{tabular}{ccccc}
\hline Trilobite biozone & N specimens & N species observed & $\mathbf{D}_{\text {н0 }}$ & J \\
\hline $\mathrm{V}_{1}$ & 70 & 7 & $8(7-21)$ & 0.57 \\
$\mathrm{~V}_{2}$ & 194 & 22 & $62(28-282)$ & 0.55 \\
\hline
\end{tabular}

Very few known cephalopod faunas are stratigraphically directly comparable with the interval of the $\mathrm{V}_{2}$ division of the Olenidsletta Member, which can be correlated with the Didymograptus bifidus Isograptus victoriae lunatus graptolite zones, latest Floian (Cooper \& Fortey 1982; see Goldman et al. 2020 for correlation). This situation has not changed since the two seminal publications of Flower (1968) and Hook \& Flower (1977) which are to date the only two reports from Laurentian latest Floian - earliest Dapingian cephalopod occurrences. A general overview on cephalopod occurrences within the Catoche Formation, Newfoundland, gives sparse additional information from eastern Laurentia (Flower 1979). Notably, several genera are shared between the Olenidsletta Member and the roughly time equivalent lower part of the Wah Wah Formation, Ibex area, Utah, USA (see, e.g., Hook \& Flower 1977; Fortey \& Droser 1999; Loch \& Ethington 2017, for correlation). Of the 17 genera recorded from the $\mathrm{V}_{2}$ interval, four genera (Buttsoceras, Catoraphiceras, Protocycloceras, and Trocholitoceras) also occur in the Wah Wah Formation. Two of these genera, Protocycloceras (see above) and Buttsoceras, are relatively widespread across Laurentia (Flower 1962, 1964: 150-153; Evans 2011) and are also reported from the Catoche Formation of western Newfoundland (Flower 1979). Additionally, four of the cephalopod genera from $\mathrm{V}_{2}$, Cycloplectoceras, Cyclostomiceras, Lawrenceoceras, and Litoceras have their type localities in Laurentian, specifically, eastern Laurentian strata. This listing results in a picture of an Olenidsletta cephalopod fauna, which altogether has a strong eastern Laurentian aspect, which is not surprising given prior knowledge from previous works on trilobites and brachiopods (e.g., Fortey 1975a, 1980; Fortey \& Barnes 1977; Hansen \& Holmer 2010, 2011).

However, Bactroceras and Eosomichelinoceras, which are by far the most abundant genera in the $\mathrm{V}_{2}$ collections (Fig. 54), are either unknown or very rare (see Flower 1968: 24) at other Laurentian localities. Instead, they are described from roughly time equivalent strata in deep neritic or basinal depositional settings in South America and South China (Kröger et al. 2007; Aubrechtová 2015). And although the Chinese (North and South China) cephalopod occurrences of the Floian-Dapingian boundary interval are generally in need of a revision, the recognition of a "Shelf Slope-Basin Cyclostomiceras Biofacies" by Xiao et al. (2006) for South China, which also contains Bactroceras, indicates some faunal overlap with middle - late Floian faunas of the Olenidsletta Member. This seemingly paradoxical relation can directly be compared with the occurrences of the Olenidsletta trilobite species Carolinites and Opipeuter, which had a pelagic lifestyle and therefore a global distribution with sporadic occurrences, e.g., in Bolivia and elsewhere (e.g., Fortey 1974; Fortey \& Barnes 1977; Zhou \& Zhou 2019). Cosmopolitan distributions are also known from several linguliform brachiopods of the Olenidsletta Member, which are interpreted as forms that had a long pelagic larval stage (Hansen \& Holmer 2010, 2011). The small spherical protoconch, known also from Bactroceras and Eosomichelinoceras from the Olenidsletta Member (Fig. 12J) are evidence of pelagic early life stages of these genera (see also Kröger et al. 2009a). 
Furthermore, the graptolite fauna of the Olenidsletta Member can be directly compared with faunas of Australia and New Zealand assigned to the "Pacific Province" (Cooper \& Fortey 1982). The terms "Atlantic Province" and "Pacific Province" have been considered misleading, because they refer to modern geography, rather than reflecting different conditions of surface water temperature and depth stratification of temperature and oxygenation (Goldman et al. 2013; Maletz \& Bates 2017). Vertical niche partitioning resulting from the presence of upwelling plumes and related bioproductivity gradients appear to be a specific feature of the Pacific Province (Cooper et al. 2012a).

The co-occurrence of taxa with Laurentian affinities, and at the same time, of taxa with distant occurrences on the palaeo-globe is a characteristic feature of the Olenidsletta Member that could be attributed to the pelagic habitat of the preserved fauna. The relatively high temporal turnover could be a result of faunal change after local anoxic/euxinic episodes related to upwelling and eustatic sea level change.

\section{Habitat depth versus depositional depth}

The calculation of the septal strength resulted in maximum habitat depths for Bactroceras minor sp. nov. of $108 \mathrm{~m}$ for the large specimen, FMNH-P30215, and $769 \mathrm{~m}$ for the smaller specimen, FMNH-P30229. In Svalbardoceras gen. nov. the maximum calculated habitat depths are 474-540 m (Table 2). The only sufficiently well preserved Eosomichelinoceras phragmocone had an implosion depth of $743 \mathrm{~m}$. These high depth ranges of the shells are typical for longiconic orthocones and are interpreted as evidence of a pelagic, vertically migrating lifestyle in these forms (Hewitt \& Westermann 1996; Westermann 1998). The high depth tolerance of orthocones contrast with that obtained from breviconic cyrtocones. The small cyrtoconic Olenidslettoceras farmi gen. et sp. nov. has an implosion depth of $50 \mathrm{~m}$ only, and calculations from conchs of Valhalloceras floweri result in an implosion depth of $53 \mathrm{~m}$. These numbers

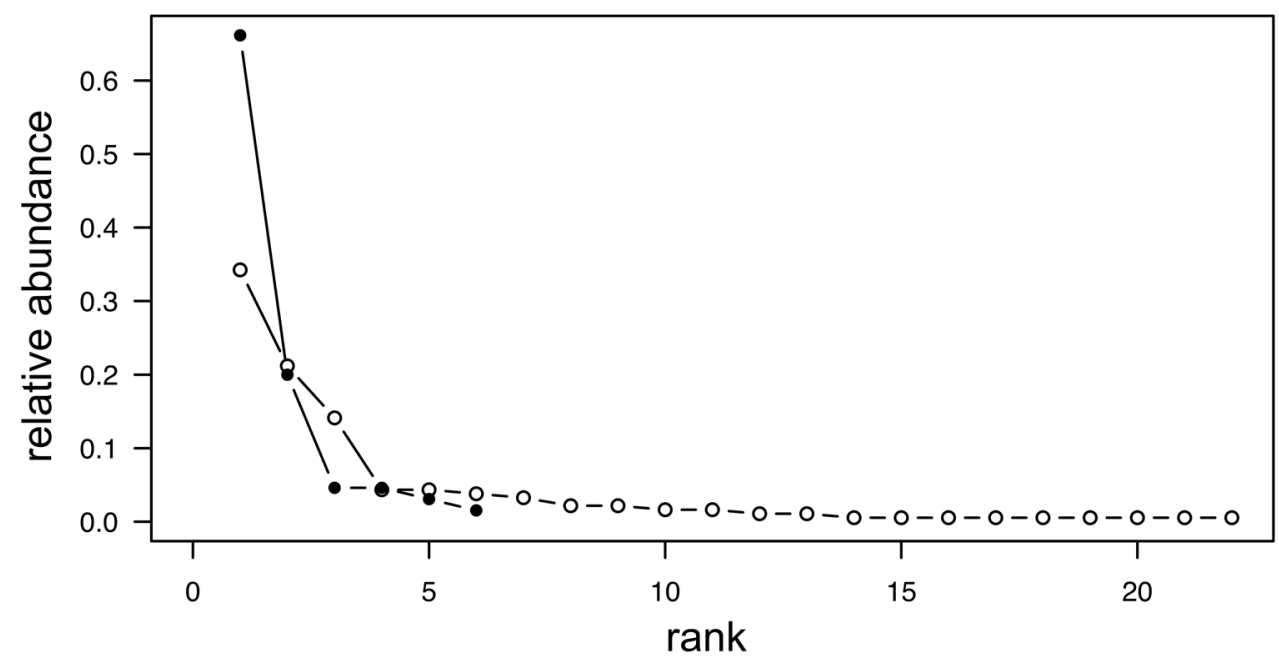

\footnotetext{
- beds PO 07 and PO 7.5 Rank:

1. Svalbardoceras sterna gen. et sp. nov.

2. Hinlopoceras tempestatis gen. et sp. nov.

3. Hinlopoceras venti gen. et sp. nov.

4. Bactroceras boliviensis Aubrechtová, 2015

5. Deltoceras beluga sp. nov.

6. Protocycloceras sp.
}

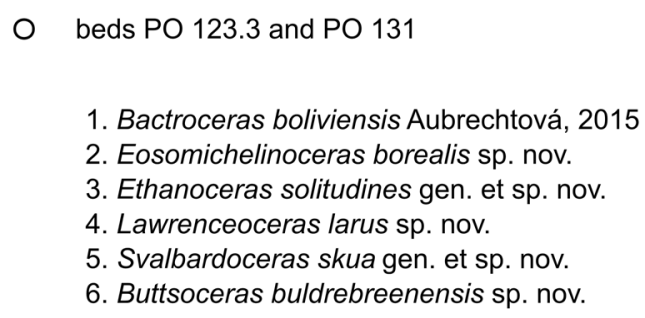

Fig. 54. Rank abundance diagram of cephalopod rich horizons of the $V_{1}$ (black circles) and $V_{2}$ (white circles) trilobite biozone with ranks of the six most important species listed. 
Table 2. Septal strength measurements and implosion depths (calculated after Hewitt \& Westermann 1996) of phragmocones of the Olenidsletta Member, Floian, Ordovician of the Profilstranda section, Ny Friesland, Spitsbergen.

\begin{tabular}{|c|c|c|c|c|c|c|c|}
\hline $\begin{array}{c}\text { FMNH } \\
\text { nr }\end{array}$ & taxon & bed & $\begin{array}{c}\text { septal } \\
\text { curvature } \\
\text { in } \mathbf{m m}\end{array}$ & $\begin{array}{c}\text { septal } \\
\text { diameter } \\
\text { in } \mathbf{m m}\end{array}$ & $\begin{array}{c}\text { septal } \\
\text { thickness } \\
\text { in } \mathbf{m m}\end{array}$ & imploded & $\begin{array}{l}\text { implosion } \\
\text { depth }\end{array}$ \\
\hline P30259 & B. boliviensis Aubrechtová & PO 123.3 & 2.3 & 7 & 0.078 & no & 700 \\
\hline P30215 & B. boliviensis Aubrechtová & PO 131 & 8 & 22 & 0.094 & no & 109 \\
\hline P30229 & B. boliviensis Aubrechtová & PO 131 & 4 & 13 & 0.156 & no & 768 \\
\hline P30430 & B. buldrebreenense sp. nov. & PO 131 & 7 & 22 & 0.125 & no & 176 \\
\hline P30431 & Cyptendoceratid indet. & PO 131 & 3.5 & 20 & 0.063 & yes & 24 \\
\hline P30402 & E. solitudines gen. et sp. nov. & PO 123.3 & 2.5 & 7 & 0.078 & no & 743 \\
\hline P30334 & O. farmi gen. et sp. nov. & PO 123.3 & 1.5 & 11 & 0.06 & yes & 50 \\
\hline P30411 & P. minor sp. nov. & PO 131 & 3 & 9 & 0.063 & no & 273 \\
\hline P30408 & S. skua gen. et sp. nov. & PO 123.3 & 3 & 11.5 & 0.125 & no & 530 \\
\hline P30368 & S. sterna gen. et sp. nov. & PO 7.5 & 2.2 & 8.5 & 0.094 & no & 541 \\
\hline P30371 & S. sterna gen. et sp. nov. & PO 7.5 & 2.1 & 8.7 & 0.094 & no & 474 \\
\hline P30340 & V. floweri Evans \& King & PO 131 & 1.4 & 13.3 & 0.094 & no & 53 \\
\hline
\end{tabular}

agree with earlier calculations of, e.g., Hewitt \& Westermann (1996) and Westermann (1998), and they support their interpretation of cyrtoconic cephalopods as shallow water dwellers with relatively limited tolerance of ambient pressure.

The septal strength calculation (Table 2) also helps to constrain the depositional depth of the individual sampling horizons, because at horizon PO 131 conchs with implosion depths of $24 \mathrm{~m}$ are imploded (FMNH-P30431) and conchs with implosion depths of $53 \mathrm{~m}$ (FMNH-P30340) and 109 m(FMNH-P30215) are not imploded. In sampling horizon PO 123.3 a conch with a maximum habitat depth of $50 \mathrm{~m}$ is imploded (FMNH-P30215), and the conchs of Svalbardoceras gen. nov. and Esosomichelinoceras with implosion depths of $>400 \mathrm{~m}$ are not imploded (Table 2). In samples from horizon PO 7.5 imploded conchs of Svalbardoceras gen. nov. are common. These imploded conchs, however, must be interpreted with caution, because dissolution and partial erosion of the shells prior to burial or after syndepositional reworking is prevalent in horizon PO 7.5. Chemical weakening of the shells that sank into and were deposited on and within anoxic/euxinic substrate could have facilitated rapid buckling and implosion under much lower hydrostatic pressures. Furthermore, poor preservation of the shells or slight deviations of the cutting surface from the median plane could introduce error in measurements of septal thickness and result in misleading calculations of implosion depth. Additional measurements and a more detailed analysis are needed to further constrain the preliminary results of septal strength calculations presented herein. 


\section{Thriving in the open - small orthoconic cephalopods and the open seas of the Early Palaeozoic}

The most abundant cephalopods in the lower part of the Olenidsletta Member $\left(\mathrm{V}_{1}\right)$ are Hinlopoceras gen. nov. and Svalbardoceras gen. nov. The genera Bactroceras and Eosomichelinoceras dominate the abundance in the middle part $\left(\mathrm{V}_{2}\right)$ of the member (Fig. 54). Bactroceras and Eosomichelinoceras are stick-like, slender orthocones that can reach considerable conch sizes. In the Olenidsletta Member Bactroceras is the species with the largest shell, reaching conch diameters of more than $40 \mathrm{~mm}$, and with an angle of ca $4^{\circ}$ grew to lengths of up to $0.6 \mathrm{~m}$. The conchs of Hinlopoceras gen. nov. and Svalbardoceras gen. nov. are significantly shorter: they expand with an angle of $7-14^{\circ}$ and reached maximum lengths of $0.15-0.2 \mathrm{~m}$.

The two contrasting morphologies, short vs long orthoconic, are a recurring theme in cephalopod assemblages of the Early Palaeozoic. Examples of short and long orthocones in mass occurrences are, e.g., Rioceras escandei Kröger \& Evans, 2011 and Bactroceras mourguesi Kröger \& Evans, 2011 in the Tremadocian strata of the Montagne Noir (Kröger \& Evans 2011); Isorthoceras albersi (Miller \& Faber, 1894) and Ordogeisonoceras amplicameratum (Hall, 1847) in the Katian Clays Ferry Formation of Kentucky, USA (Frey 1995); Orthoceras gregarium Sowerby in Murchison, 1839 and Temperoceras ludense (Sowerby, 1839) in the Ludlow Series of the Welsh Borderland, UK (Hewitt \& Watkins 1980); and Arionoceras submoniliforme (Meneghini, 1857) and Columenoceras grande (Meneghini, 1857) in the Late Silurian sediments of Sardinia (Serpagli \& Gnoli 1977). In some strata the large forms dominate in abundance, in others both morphologies occur in balanced numbers. Often, the small forms are overwhelmingly dominant, such as in the Elgin Member, Maquoketa Formation, Katian of Iowa, USA, where Isorthoceras sociale (Hall, 1847) occurs in rock-forming abundance (Miller \& Youngquist 1949). The Elgin Member cephalopod coquina is in several aspects very similar to the mass occurrence of Svalbardoceras sterna gen. et sp. nov. in bed PO 7.5 of the Olenidsletta Member, because it consists of a highly uneven cephalopod assemblage dominated by small orthocones (Miller \& Youngquist 1949). It is interbedded within dark shales, which represent anoxic to dysoxic bottom conditions; and it is interpreted to represent a condensed section that was deposited during rapid transgression at a shelf/ slope boundary at ca $200 \mathrm{~m}$ below sea level (Raatz \& Ludvigson 1996). Small orthocones also dominate the deeper parts of the Ludlow shelf in the Welsh Borderland (Hewitt \& Watkins 1980), and the small orthocone Kopaninoceras Kiselev, 1969 is the predominant taxon in the Silurian graptolitic shale facies of the Barrandian area (Czech Republic) (see, e.g., Hewitt \& Westermann 1996).

This general picture is in accordance with the occurrences within the Olenidsletta Member. The cephalopod coquina of bed PO 7.5 occurs in a part of a section with black nodular, bituminous limestones which are interbedded with dark shales, and which toward the top become increasingly more shaly, bituminous and poor in benthos (Fig. 3). Bed PO 7.5 is interpreted as representing a top of a parasequence within a generally transgressive interval of the lower Olenidsletta Member (see Kröger et al. 2017).

A model for the deposition of cephalopod concentrations in black, bituminous limestones under a transgressive regime has been proposed based on Early Silurian occurrences in the East Siberian Basin (Bogolepova 1998). There, the concentrations occur in diachronous facies belts across the basin, which are interpreted as the results of geographically shifting upwelling zones with oxygen depleted, nutrient rich deep waters (Bogolepova 1998). A similar situation could have resulted in the deposition of the cephalopod concentrations in the $\mathrm{V}_{1}$ division of the Olenidsletta Member (Fig. 55).

However, not all cephalopod mass occurrences can be attributed to rapid sea level rise. Cephalopod rich facies belts can also result from decreasing sea levels in originally very deep water sites that became temporarily shallower during a regression (Bogolepova 1998; Kř́ž 1998; Kröger 2008). This may have been the case during the deposition of the cephalopod concentrations in division $\mathrm{V}_{2}$ of the Olenidsletta Member, specifically in bed PO 131 (see also Kröger et al. 2017). Here, septal implosion 
is less and septal strength calculations (Table 2, see above) indicate depositional depths of only 25$50 \mathrm{~m}$. Notably, the assemblages of the $\mathrm{V}_{2}$ interval are more diverse and dominated by long orthocones, such as Eosomichelinoceras (bed PO 123.3) and large specimens of Bactroceras (bed PO 131). Short orthocones, such as Hinlopoceras gen. nov. and Svalbardoceras gen. nov, in contrast, are dominant in the cephalopod horizons of the $\mathrm{V}_{1}$ interval, where many of their phragmocones are imploded. The imploded phragmocones of the $\mathrm{V}_{1}$ interval horizons are probably a result of the early dissolution of the calcitic shells under anoxic/euxinic bottom conditions with higher levels of free hydrogen sulfide and do not reflect the hydrostatic buckling pressure of the shells of the living animals (which are $>400 \mathrm{~m}$ ). The sea level changes during the time of the deposition of the Olenidsletta Member were unlikely to be more than $80 \mathrm{~m}$, which is the eustatic sea level amplitude given for the Floian in Haq \& Schutter (2008). The maximum water depth, thus, is unlikely to have exceeded $130 \mathrm{~m}$ during the deposition of the Olenidsletta Member. This estimation is in agreement with the presence of photic zone biomarker signatures in all Olenidsletta Member samples (Lee et al. 2019).

The distinct cephalopod assemblages thus reflect a niche differentiation of pelagic cephalopods within the photic zone, probably along a water temperature and/or oxygenation gradient. Therein, large and long orthocones dominated the shallow, more proximal habitats and the small and short orthocones dominated the deeper, more distal habitats (Fig. 55). Evidence for a pronounced Floian pelagic niche differentiation was known previously from conodonts, which were deposited at the eastern shelf edge of Laurentia along an original temperature gradient of ca $7-8^{\circ} \mathrm{C}$ and within a water depth range of ca 250-300 m (Wheeley et al. 2018). Niche differentiation of pelagic Floian faunas is also relatively well known from graptolites (e.g., Cooper et al. 1991, 2012a; Egenhoff \& Maletz 2007; Goldman et al. 2013; Maletz \& Bates 2017). The presence of a highly differentiated pelagic cephalopod fauna in the Olenidsletta Member indicates that highly diverse niches existed among Floian pelagic animals at the top of the marine food chain as well.

\section{Conclusion}

The collection of cephalopods from eight sampling horizons within the Olenidsletta Member, Valhallfonna Formation, Floian from Profilstranda, Ny Friesland, Spitsbergen resulted in the detection of

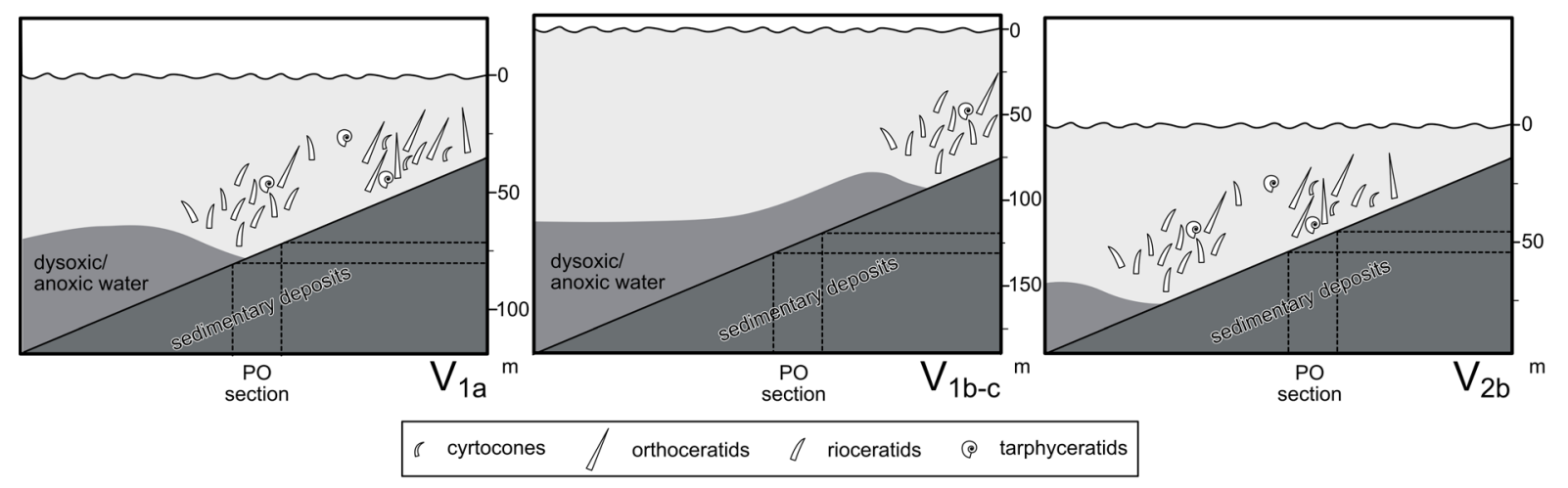

Fig. 55. Model of cephalopod habitat and faunal composition for three intervals (trilobite biozones $V_{1 a}$, $\mathrm{V}_{1 \mathrm{~b}-\mathrm{c}}, \mathrm{V}_{2 \mathrm{~b}}$ ) of the depositional time of the Olenidsletta Member, Floian, Ordovician at Profilstranda (PO) section, Ny Friesland, Spitsbergen. Absolute water depth is estimated from septal implosion depths of cephalopods during $\mathrm{V}_{2 \mathrm{~b}}$, from presence of photic zone biomarker signatures in all Olenidsletta Member samples (Lee et al. 2019), and from a global amplitude of eustatic sea level change of ca $80 \mathrm{~m}$ during the Floian (Haq \& Schutter 2008). 
31 species, 20 genera, and 12 families from the Ellesmerocerida, Endocerida, Riocerida, Dissidocerida, Orthocerida, Tarphycerida, and Oncocerida (Table 3). Of these, five genera and 18 species are new.

The turnover between the sampling horizons and between the different stratigraphic intervals of the Olenidsletta Member is high. Only one species, Bactroceras boliviensis, ranges through the entire member, and only four of the 22 cephalopod species of the $V_{2}$ trilobite assemblage zone range through the sampling horizons of this zone. In each of the main sampling horizons a different orthoconic longiconic cephalopod species dominates. The evenness of the cephalopod assemblages of the collections from the two trilobite assemblage zones of the Olenidsletta Member, the zones $\mathrm{V}_{1}$ and $\mathrm{V}_{2}$, is similar and relatively low (ca $\mathrm{J}=0.6$ ), but the diversity of the latest Floian $\mathrm{V}_{2}$ zone is more than seven times higher than that of the lower-middle Floian $\mathrm{V}_{1}$ zone. The assemblage of the $\mathrm{V}_{2}$ also differs from that of the $\mathrm{V}_{1}$ zone in containing a variety of cyrtoconic breviconic cephalopods.

These differences in composition of the cephalopod assemblages are interpreted as reflecting changing depth and oxygenation conditions during the deposition of the Olenidsletta Member and are consistent with interpretations of changes within the trilobite and conodont assemblages (Fortey \& Barnes 1977; Fortey 1980). The co-occurrence of endemic species, species with Laurentian affinities, and species with global distributions is interpreted as resulting from a high vertical niche differentiation among the preserved cephalopods and from eustatically generated lateral shifts of facies zones.

Calculations of implosion depths of phragmocones of several species from different sample horizons are in general agreement with previous calculations from orthoconic and breviconic cephalopods where brevicones have low implosions depths of $<100 \mathrm{~m}$ and orthocones have implosion depths of several hundred meters (e.g., Hewitt \& Westermann 1996). The presence of imploded orthoconic shells in some sample horizons, which are resistant to hundreds of meters of water depth, is interpreted as resulting from chemical weakening after deposition under anoxic/euxinic conditions. Implosion depths of intact phragmocones indicate minimum depositional depths of ca $50 \mathrm{~m}$ for the sample horizon with the interpreted lowest sea level. Based on these calculations, depositional depths of 50-130 m are plausible for the Olenidsletta Member, which supports independent evidence from biomarker signatures (Lee et al. 2019).

Several cephalopod species of the Olenidsletta Member represent odd mosaics of morphological features of existing cephalopods and/or cannot be unambiguously assigned to one of the existing cephalopod families or orders. Most remarkable is the presence of a continuous endosiphuncular lining in Bactroceras boliviensis, which is in conflict with the simplified dichotomic distinction between "vacuosiphonate baltoceratids" and endosiphuncular deposit bearing dissidoceratids in high level classification (e.g., King \& Evans 2019). Results from a cladistic analysis, undertaken herein, suggest that endosiphuncular lining with high probability evolved twice or multiple times within the Riocerida and Dissidoceroda-Orthocerida clades. The occurrence of various combinations of characters in species such as Valhalloceras floweri and Olenidslettoceras farmi gen. et sp. nov. sheds new light on the early evolution of the Oncocerida.

In conclusion, the thorough description and palaeoecological analysis of the cephalopods of the Olenidsletta Member presented herein demonstrates that latest Floian pelagic assemblages represent highly differentiated niches, dependent on water depth, oxygenation level as well as related attributes, such as temperature and availability of trophic resources. The Olenidsletta Member contains several species which are crucial for the understanding of the evolution of high-level taxonomic groups of the early Palaeozoic Cephalopoda. Likely, future studies of distal and pelagic cephalopod faunas of the Early Ordovician elsewhere will have a similar great potential to provide valuable information on the structure of pelagic ecosystems and their development and evolution at the dawn of the Ordovician radiation. 
Table 3. Number of macroscopic occurrences of cephalopod specimens per species in six of nine sampling horizons (PO-numbers) within the Olenidsletta Member, Floian, Ordovician, Profilstranda section, Ny Friesland, Spitsbergen. Microscopic specimens (apex fragments) are excluded from this list (see methods).

\begin{tabular}{|c|c|c|c|c|c|c|c|}
\hline Family & Species & $\begin{array}{l}\text { PO } \\
3.7\end{array}$ & $\begin{array}{c}\text { PO } \\
4\end{array}$ & $\begin{array}{c}\text { PO } \\
7\end{array}$ & $\begin{array}{l}\text { PO } \\
7.5\end{array}$ & $\begin{array}{c}\text { PO } \\
123.3\end{array}$ & $\begin{array}{l}\text { PO } \\
131\end{array}$ \\
\hline \multirow{2}{*}{ Bassleroceratidae Ulrich et al., 1944} & Lawrenceoceras ebenus sp. nov & 0 & 0 & 0 & 0 & 1 & 0 \\
\hline & Lawrenceoceras larus sp. nov & 0 & 0 & 0 & 0 & 1 & 6 \\
\hline Cyclostomiceridae Foerste, 1925 & Cyclostomiceras profilstrandense sp. nov. & 0 & 0 & 0 & 0 & 1 & 0 \\
\hline $\begin{array}{l}\text { Proterocameroceratidae } \\
\text { Kobayashi, } 1937\end{array}$ & Proterocameroceras valhallfonnense sp. nov. & 0 & 0 & 0 & 0 & 0 & 3 \\
\hline \multirow[t]{5}{*}{ Rioceratidae Kröger \& Evans, 2011} & Ethanoceras solitudines gen. et sp. nov. & 0 & 0 & 0 & 0 & 27 & 2 \\
\hline & Hinlopoceras tempestatis gen. et sp. nov. & 0 & 0 & 15 & 0 & 0 & 0 \\
\hline & Hinlopoceras venti gen. et sp. nov. & 0 & 0 & 1 & 2 & 0 & 0 \\
\hline & Svalbardoceras sterna gen. et sp. nov. & 0 & 0 & 2 & 43 & 0 & 0 \\
\hline & Svalbardoceras skua gen. et sp. nov. & 0 & 0 & 0 & 0 & 9 & 0 \\
\hline Bactroceratidae King \& Evans, 2019 & Bactroceras boliviensis Aubrechtová, 2015 & 0 & 0 & 1 & 2 & 2 & 63 \\
\hline \multirow[t]{4}{*}{ Cyptendoceratidae Zhuravleva, 1994} & Cyptendoceras sp. A. & 0 & 0 & 1 & 0 & 0 & 0 \\
\hline & Catoraphiceras sp. & 0 & 0 & 0 & 0 & 0 & 1 \\
\hline & Hemichoanella occulta sp. nov. & 0 & 0 & 0 & 0 & 0 & 1 \\
\hline & cyptendoceratid gen. et sp. indet. & 0 & 0 & 0 & 0 & 0 & 1 \\
\hline \multirow[t]{4}{*}{ Troedssonellidae Kobayashi, 1935} & Buttsoceras buldrebreenense sp. nov. & 0 & 0 & 0 & 0 & 0 & 5 \\
\hline & Protocycloceras lamarcki Billings, 1859 & 1 & 1 & 0 & 0 & 0 & 0 \\
\hline & Protocycloceras minor sp. nov. & 0 & 0 & 0 & 0 & 0 & 6 \\
\hline & Protocycloceras sp. & 0 & 0 & 0 & 0 & 1 & 0 \\
\hline Baltoceratidae Kobayashi, 1935 & Eosomichelinoceras borealis sp. nov. & 0 & 0 & 0 & 0 & 42 & 1 \\
\hline \multirow[t]{2}{*}{ Tarphyceratidae Hyatt, 1894} & Cycloplectoceras hinlopense sp. nov. & 0 & 0 & 0 & 0 & 0 & 1 \\
\hline & Deltoceras beluga sp. nov. & 0 & 0 & 3 & 0 & 0 & 0 \\
\hline Estonioceratidae Hyatt in Zittel, 1900 & estonioceratid gen. et. sp. indet. & 0 & 0 & 0 & 1 & 0 & 0 \\
\hline \multirow[t]{3}{*}{ Trocholitidae Chapman, 1857} & Litoceras profilbekkenense sp. nov. & 0 & 0 & 0 & 0 & 0 & 1 \\
\hline & $\begin{array}{l}\text { Trocholitoceras juvenicostatum Ulrich et al., } \\
1942\end{array}$ & 0 & 0 & 0 & 0 & 0 & 6 \\
\hline & Trocholitoceras walcotti Hyatt, 1894 & 0 & 0 & 0 & 0 & 0 & 3 \\
\hline \multirow[t]{3}{*}{$\begin{array}{l}\text { Phthanoncoceratidae Evans \& King, } \\
1990\end{array}$} & $\begin{array}{l}\text { Nyfrieslandoceras bassleroceroides gen. et } \\
\text { sp. nov. }\end{array}$ & 0 & 0 & 0 & 0 & 0 & 3 \\
\hline & Olenidslettoceras farmi gen. et sp. nov. & 0 & 0 & 0 & 0 & 2 & 0 \\
\hline & Valhalloceras floweri Evans \& King, 1990 & 0 & 0 & 0 & 0 & 1 & 4 \\
\hline Family indet. & Order, gen. et sp. indet. A & 0 & 0 & 0 & 0 & 0 & 1 \\
\hline
\end{tabular}




\section{Acknowledgments}

Many thanks to Melanie J. Hopkins (American Museum of Natural History [AMNH], New York, USA) for initially inviting B.K. to take part in the expedition to Svalbard. We thank Franziska Franeck (F.F.) (Natural History Museum [NHM], Oslo, Norway), Melanie J. Hopkins (M.J.H.), Seth Finnegan (University of California, Berkeley, USA) and Håvard Hansen (Norsk Polarinstitut, Svalbard, Norway) for being such a good team in the field. B.K. is grateful for the general support during preparation and realization of the project by David Bruton (Natural History Museum [NHM], Oslo, Norway), Ebony (Longyearbyen, Svalbard, Norway), Ethan (Profilbekken, Svalbard, Norway), Richard Fortey (NHM London), Håvard Hansen, Nils Martin Hanken (Tromsø/Oslo, Norway), Stig Hennigsen and family (Longyearbyen, Svalbard, Norway), Jim Johansen (Norsk Polarinstitut, Svalbard, Norway), Hårvard Kårstad (Ørsta, Norway), Henriika Kivilä (Helsinki, Finland), Rupert Krapp (Norsk Polarinstitut, Svalbard, Norway), Lee Hsiang Liow (NHM Oslo, Norway), Ivar Midtkandal (Oslo, Norway), Hans Arne Nakrem (NHM Oslo, Norway), Svend Stouge (University of Copenhagen, Denmark), Mariah Slovacek (AMNH), and thanks also the Sysselmannen på Svalbard for permissions of fieldwork. The manuscript benefited from an early review by M.J.H. David H. Evans' (Peterborough, UK) thorough review helped much to improve the quality of the manuscript. Susan Scholze (University of Helsinki, Finland) helped prepare the samples and we are grateful for her preparation work. Fieldwork was conducted under permit 2016/00110-2. The project was financially supported by the Swiss National Science Foundation project 200020169627 (A.P.), Niarchos Foundation (M.J.H.), the National Geographic Society (F.F.), and the Societas Scientarium Fennica (B.K.). This work is part of Research in Svalbard (RIS) ID 10467.

\section{References}

Adrain J.M., Edgecombe G.D., Fortey R.A., Hammer Ø., Laurie J.R., McCormick T.O., Waisfeld B.G., Webby B.D., Westrop S.R. \& Zhou Z.-Y. 2004. Trilobites. In: Webby B.D., Paris F., Droser M. \& Percival I. (eds) The Great Ordovician Diversification Event: 231-254. Columbia University Press, New York. https://doi.org/10.7312/webb12678-025

Aubrechtová M. 2015. A revision of the Ordovician cephalopod Bactrites sandbergeri Barrande: systematic position and palaeobiogeography of Bactroceras. Geobios 48: 193-211.

https://doi.org/10.1016/j.geobios.2015.03.002

Balashov E.G. 1962. Nautiloidei ordovika sibirskoi platformy. Izdatel'stvo Leningradskogo Universiteta, St. Petersburg.

Balashov E.G. 1968. Endoceratoidei ordovika SSSR. Isdatelstvo Leningradskogo Universiteta, Leningrad.

Bergström S.M., Chen X., Gutiérrez-Marco J.C. \& Dronov A. 2009. The new chronostratigraphic classification of the Ordovician System and its relation to major regional series and stages and to $\delta^{13} \mathrm{C}$ chemostratigraphy. Lethaia 42: 97-107. https://doi.org/10.1111/j.1502-3931.2008.00136.x

Billings E. 1859. Fossils of the calciferous sandrock, including those of a deposit of White Limestone at Mingan, supposed to belong to the formation. Canadian Naturalist and Geologist, Proceedings of the Society of Natural History Montreal 4: 345-367.

Bogolepova O.K. 1998. Silurian cephalopod beds from North Asia. New York State Museum Bulletin 491: 199-207.

Bremer K. 1988. The limits of amino acid sequence data in angiosperm phylogenetic reconstruction. Evolution 42: 795-803. https://doi.org/10.1111/j.1558-5646.1988.tb02497.x

Bremer K.R. 1994. Branch support and tree stability. Cladistics 10: 295-304. https://doi.org/10.1111/j.1096-0031.1994.tb00179.x 
Brett K.D. \& Westrop S.R. 1996. Trilobites of the Lower Ordovician (Ibexian) Fort Cassin Formation, Champlain Valley region, New York State and Vermont. Journal of Paleontology 70 (3): 408-427. https://doi.org/10.1017/S0022336000038348

Chao A., Chiu C.-H. \& Jost L. 2016. Phylogenetic diversity measures and their decomposition: a framework based on Hill numbers. In: Pellens R. \& Grandcolas P. (eds) Biodiversity Conservation and Phylogenetic Systematics: 141-172. Topics in Biodiversity and Conservation vol. 14. Springer, Cham, Switzerland. https://doi.org/10.1007/978-3-319-22461-9_8

Cocks L.R.M. \& Torsvik T.H. 2011. The Palaeozoic geography of Laurentia and western Laurussia: a stable craton with mobile margins. Earth-Science Reviews 106: 1-51.

https://doi.org/10.1016/j.earscirev.2011.01.007

Cooper R.A. \& Fortey R.A. 1982. The Ordovician graptolites of Spitsbergen. Bulletin of the British Museum (Natural History), Geology 36: 157-302. Available from https://www.biodiversitylibrary.org/page/2364287 [accessed 25 Oct. 2021].

Cooper R.A., Fortey R.A. \& Lindholm K. 1991. Latitudinal and depth zonation of early Ordovician graptolites. Lethaia 24: 199-218. https://doi.org/10.1111/j.1502-3931.1991.tb01468.x

Cooper R.A., Rigby S., Loydell D.K. \& Bates D.E.B. 2012a. Palaeoecology of the Graptoloidea. EarthScience Reviews 112: 23-41. https://doi.org/10.1016/j.earscirev.2012.01.001

Cooper R.A., Sadler P.M., Hammer O. \& Gradstein F.M. 2012b. Chapter 20 - The Ordovician Period. In: Gradstein F.M., Schmitz J.G., Ogg M.D. \& Ogg G.M. (eds) The Geologic Time Scale 2012: 489-523. Elsevier, Boston. https://doi.org/10.1016/B978-0-444-59425-9.00020-2

Cooper R.A., Sadler P.M., Munnecke A. \& Crampton J.S. 2014. Graptoloid evolutionary rates track Ordovician-Silurian global climate change. Geological Magazine 151: 349-364.

https://doi.org/10.1017/S0016756813000198

Dzik J. 1984. Phylogeny of the Nautiloidea. Palaeontologia Polonica 45: 1-203.

Egenhoff S. \& Maletz J. 2007. Graptolites as indicators of maximum flooding surfaces in monotonous deep-water shelf successions. Palaios 22: 373-383. https://doi.org/10.2110/palo.2005.p05-096r

Evans D.H. 2005. The Lower and Middle Ordovician cephalopod faunas of England and Wales. Monograph of the Palaeontographical Society 628: 1-81.

Evans D.H. 2011. The cephalopod faunas of the Durness Limestone (Lower and early Middle Ordovician) of Northwest Scotland. Monograph of the Palaeontographical Society 637: 1-131.

Evans D.H. \& King A.H. 1990. The affinities of early oncocerid nautiloids from the Lower Ordovician of Spitsbergen and Sweden. Palaeontology 33: 623-630.

Evans D.H. \& King A.H. 2012. Resolving polyphyly within the Endocerida: the Bisonocerida nov., a new order of early palaeozoic nautiloids. Geobios 45: 19-28. https://doi.org/10.1016/j.geobios.2011.11.015

Felsenstein J. 1985. Confidence limits on phylogenies: an approach using the bootstrap. Evolution 39: 783-791. https://doi.org/10.1111/j.1558-5646.1985.tb00420.x

Ferretti A. \& Krŕýz J. 1995. Cephalopod limestone biofacies in the Silurian of the Prague Basin, Bohemia. Palaios 10: 240-253. https://doi.org/10.2307/3515255

Finnegan S. \& Droser M.L. 2005. Relative and absolute abundance of trilobites and rhynchonelliform brachiopods across the Lower/Middle Ordovician boundary, eastern Basin and Range. Paleobiology 31: 480-502. https://doi.org/10.1666/0094-8373(2005)031[0480:RAAAOT]2.0.CO;2

Flower R.H. 1941. Development of the mixochoanites. Journal of Paleontology 15: 523-548. 
Flower R.H. 1955. Status of endoceroid classification. Journal of Paleontology 29: 329-371. Available from https://www.jstor.org/stable/1300321 [accessed 19 Nov. 2021].

Flower R.H. 1962. Part 1, Revision of Buttsoceras. Part 2, Notes on the Michelinoceratida. State Bureau of Mines and Mineral Resources, New Mexico Institute of Mining and Technology, Memoir 10: 1-58.

Flower R.H. 1964. The nautiloid order Ellesmeroceratida (Cephalopoda). State Bureau of Mines and Mineral Resources, New Mexico Institute of Mining and Technology, Memoir 12: 1-164.

Flower R.H. 1968. Part I. The first great expansion of the actinoceroids. Part II. Some additional Whiterock cephalopods. New Mexico Bureau of Mines and Mineral Resources, Memoir 19: 1-120.

Flower R.H. 1979. St. George and Table Head cephalopod zonation in western Newfoundland. Papers of the Geological Survey of Canada 78: 217-224. https://doi.org/10.4095/103891

Flower R.H. \& Kummel B. 1950. A classification of the Nautiloidea. Journal of Paleontology 24: 604616.

Fortey R.A. 1974. The Ordovician trilobites of Spitsbergen: 1. Olenidae. Skrifter Norsk Polarinstitutt 160: $1-81$.

Fortey R.A. 1975a. Early Ordovician trilobite communities. Fossil and Strata 4: 331-352.

Fortey R.A. 1975b. The Ordovician trilobites of Spitsbergen: 2. Asaphidae, Nileidae, Raphiophoridae and Telephinidae of the Valhallfonna Formation. Skrifter Norsk Polarinstitutt 162: 1-125.

Fortey R.A. 1980. The Ordovician trilobites of Spitsbergen: 3. Remaining trilobites of the Valhalla Formation. Skrifter Norsk Polarinstitutt 171: 1-113.

Fortey R.A. \& Barnes C.R. 1977. Early Ordovician conodont and trilobite communities of Spitsbergen: influence on biogeography. Alcheringa 1: 297-309. https://doi.org/10.1080/03115517708527766

Fortey R.A. \& Bruton D.L. 1973. Cambrian-Ordovician rocks adjacent to Hinlopenstretet, North Ny Friesland, Spitsbergen. Bulletin of the Geological Society of America 84: 2227-2242.

https://doi.org/10.1130/0016-7606(1973)84<2227:CRATHN>2.0.CO;2

Fortey R.A. \& Droser M.L. 1999. Trilobites from the base of the type Whiterockian (Middle Ordovician) in Nevada. Journal of Paleontology 73: 182-201. https://doi.org/10.1017/S0022336000027712

Frey R.C. 1995. Middle and Upper Ordovician Cephalopods of the Cincinnati Arch Region of Kentucky, Indiana, and Ohio. United States Geological Survey Professional Paper 1066P: 1-119.

https://doi.org/10.3133/pp1066P

Furnish W.M. \& Glenister B.F 1964. Nautiloidea-Tarphycerida. In: Teichert C. (ed.) Treatise on Invertebrate Paleontology, Part K, Mollusca 3: K343-K368. Geological Society of America and the University of Kansas Press, Boulder, Colorado.

Gee D.G. \& Teben'kov A.M. 2004. Svalbard: a fragment of the Laurentian margin. Geological Society, London, Memoirs 30: 191-206. https://doi.org/10.1144/GSL.MEM.2004.030.01.16

Goldberg S.L., Present T.M., Finnegan S. \& Bergmann K.D. 2021. A high-resolution record of early Paleozoic climate. Proceedings of the National Academy of Sciences 118: e2013083118.

https://doi.org/10.1073/pnas.2013083118

Goldman D., Maletz J., Melchin M.J. \& Junxuan F. 2013. Graptolite palaeobiogeography. Geological Society, London, Memoirs 38: 415-428. https://doi.org/10.1144/M38.26

Goldman D., Sadler P.M., Leslie S.A., Melchin M.J., Agterberg F.P. \& Gradstein F.M. 2020. Chapter 20 - The Ordovician Period. In: Gradstein F.M., Ogg J.G., Schmitz M.D. \& Ogg G.M. (eds) Geologic Time Scale 2020: 631-694. Elsevier, New York. https://doi.org/10.1016/B978-0-12-824360-2.00020-6 
KRÖGER B. \& POHLE A., Ordovician Spitsbergen cephalopods

Goloboff P.A. \& Catalano S.A. 2016. TNT version 1.5, including a full implementation of phylogenetic morphometrics. Cladistics 32: 221-238. https://doi.org/10.1111/cla.12160

Goloboff P.A., Farris J.S., Källersjö M., Oxelman B., Ramírez M.J. \& Szumik C.A. 2003. Improvements to resampling measures of group support. Cladistics 19: 324-332.

https://doi.org/10.1111/j.1096-0031.2003.tb00376.x

Guppy D.G. \& Öpik A.A. 1950. Discovery of Ordovician rocks, Kimberley Division, Western Australia. Australian Journal of Science 12: 205-206.

Gutiérrez-Marco J.C. \& Martin E.L.O. 2016. Biostratigraphy and palaeoecology of Lower Ordovician graptolites from the Fezouata Shale (Moroccan Anti-Atlas). Palaeogeography, Palaeoclimatology, Palaeoecology 460: 35-49. https://doi.org/10.1016/j.palaeo.2016.07.026

Hansen J. \& Holmer L.E. 2010. Diversity fluctuations and biogeography of the Ordovician brachiopod fauna in Northeastern Spitsbergen. Bulletin of Geoscience 85: 497-504.

https://doi.org/10.3140/bull.geosci.1178

Hansen J. \& Holmer L.E. 2011. Taxonomy and biostratigraphy of Ordovician brachiopods from northeastern Ny Friesland, Spitsbergen. Zootaxa 3076 (1): 1-122.

https://doi.org/10.11646/zootaxa.3076.1.1

Haq B.U. \& Schutter S.R. 2008. A chronology of Paleozoic sea-level changes. Science 322: 64-68. https://doi.org/10.1126/science.1161648

Harland T.L., Wallis R.H. \& Gayer R.A. 1966. A revision of the Lower Hecla Hoek succession in central north Spitsbergen and correlation elsewhere. Geological Magazine 103: 70-97.

https://doi.org/10.1017/S0016756800050433

Harland W.B. 1997. Chapter 7 Northeastern Spitsbergen. Geological Society, London, Memoirs 17: 110-131. https://doi.org/10.1144/GSL.MEM.1997.017.01.07

Hewitt R.A. \& Watkins R. 1980. Cephalopod ecology across a late Silurian shelf tract. Neues Jahrbuch für Geologie und Paläontologie, Abhandlungen 160: 96-117.

Hewitt R.A. \& Westermann G.E.G. 1996. Post-mortem behaviour of Early Paleozoic nautiloids and paleobathymetry. Paläontologische Zeitschrift 70: 405-424. https://doi.org/10.1007/BF02988081

Hintze L.F. 1953. Lower Ordovician trilobites from western Utah and eastern Nevada. Utah Geological and Mineralogical Survey Bulletin 48: 1-249.

Holm G. 1898. Palaeontologiska notiser. Om ett par Bactrites-liknande untersiluriska orthocer-former. Geologiska Föreningen i Stockholm Förhandlingar 20: 354-360.

https://doi.org/10.1080/11035899809447943

Hook S.C. \& Flower R.H. 1977. Late Canadian (Zones J, K) cephalopod faunas from southwestern United States. New Mexico Bureau of Mines and Mineral Resources, Memoir 32: 1-102.

Hopkins M. 2019. Phylogenetic analysis and revision of the trilobite subfamily Balnibarbiinae (Olenidae). American Museum Novitates 3928: 1-20. https://doi.org/10.1206/3928.1

Hsieh T.C., Ma K.H. \& Chao A. 2016. iNEXT: an R package for rarefaction and extrapolation of species diversity (Hill numbers). Methods in Ecology and Evolution 7: 1451-1456.

https://doi.org/10.1111/2041-210X.12613

Hyatt A. 1894. Phylogeny of an acquired characteristic. Proceedings of the American Philosophical Society 32: 349-647. https://doi.org/10.5962/bhl.title.59826 
King A.H. 1998. A review of the cyclostomiceratid nautiloids, including new taxa from the Lower Ordovician of Öland, Sweden. Palaeontology 41: 335-347.

King A.H. \& Evans D.H. 2019. High-level classification of the nautiloid cephalopods: a proposal for the revision of the Treatise Part K. Swiss Journal of Palaeontology 138: 65-85.

https://doi.org/10.1007/s13358-019-00186-4

Korn D. \& Klug C. 2003. Morphological pathways in the evolution of Early and Middle Devonian ammonoids. Paleobiology 29: 329-348.

https://doi.org/10.1666/0094-8373(2003)029<0329:MPITEO>2.0.CO;2

Kř́iž, J. 1998. Recurrent Silurian-Lowest Devonian cephalopod limestone of Gondwanan Europe and Perunica. New York State Museum Bulletin 491: 183-198.

Kröger B. 2008. A new genus of middle Tremadocian orthoceratoids and the Early Ordovician origin of orthoceratoid cephalopods. Acta Palaeontologica Polonica 53: 745-749.

https://doi.org/10.4202/app.2008.0417

Kröger B. \& Evans D.H. 2011. Review and palaeoecological analysis of the late Tremadocian-early Floian (Early Ordovician) cephalopod fauna of the Montagne Noire, France. Fossil Record 14: 5-34. https://doi.org/10.1002/mmng.201000013

Kröger B. \& Landing E. 2008. Onset of the Ordovician cephalopod radiation - evidence from the Rochdale Formation (middle Early Ordovician, Stairsian) in eastern New York. Geological Magazine 145: 490-520. https://doi.org/10.1017/S0016756808004585

Kröger B. \& Landing E. 2009. Cephalopods and paleoenvironments of the Fort Cassin Formation (Upper Lower Ordovician), eastern New York and adjacent Vermont. Journal of Paleontology 83: 664-693. https://doi.org/10.1666/08-181.1

Kröger B. \& Mutvei H. 2005. Nautiloids with multiple paired muscle scars from Lower-Middle Ordovician of Baltoscandia. Palaeontology 48: 781-791. https://doi.org/10.1111/j.1475-4983.2005.00478.x

Kröger B., Beresi M. \& Landing E. 2007. Early orthoceratoid cephalopods of the Argentine Precordillera (Lower-Middle Ordovician). Journal of Paleontology 81: 1266-1283. https://doi.org/10.1666/06-013.1

Kröger B., Servais T. \& Zhang Y. 2009a. The origin and initial rise of pelagic cephalopods in the Ordovician. PLoS ONE 4: e7262. https://doi.org/10.1371/journal.pone.0007262

Kröger B., Zhang Y. \& Isakar M. 2009b. Discosorids and oncocerids (Cephalopoda) of the Middle Ordovician Kunda and Aseri Regional Stages of Baltoscandia and the early evolution of these groups. Geobios 42: 273-293. https://doi.org/10.1016/j.geobios.2008.09.006

Kröger B., Finnegan S., Franeck F. \& Hopkins M. 2017. The Ordovician succession adjacent to Hinlopenstretet, Ny Friesland, Spitsbergen. American Museum Novitates 3882: 1-28.

https://doi.org/10.1206/3882.1

Laurie J.R. \& Shergold J.H. 1996. Early Ordovician trilobite taxonomy and biostratigraphy of the Emanuel Formation, Canning Basin, Western Australia, Part 1. Palaeontographica, Abteilung A 240: 65-103.

Lee C., Love G.D., Hopkins M.J., Kröger B., Franeck F. \& Finnegan S. 2019. Lipid biomarker and stable isotopic profiles through Early-Middle Ordovician carbonates from Spitsbergen, Norway. Organic Geochemistry 131: 5-18. https://doi.org/10.1016/j.orggeochem.2019.02.008

Legg D.P. 1978. Ordovician biostratigraphy of the Canning Basin, Western Australia. Alcheringa 2: 321-334. https://doi.org/10.1080/03115517808527788 
Lehnert O., Stouge S. \& Brandl P.A. 2013. Conodont biostratigraphy in the Early to Middle Ordovician strata of the Oslobreen Group in Ny Friesland, Svalbard. Zeitschrift der Deutschen Gesellschaft für Geowissenschaften 164: 149-172. https://doi.org/10.1127/1860-1804/2013/0003

Li X. \& Droser M.L. 1999. Lower and Middle Ordovician shell beds from the Basin and Range province of the western United States (California, Nevada, and Utah). Palaios 14: 215-233.

https://doi.org/10.2307/3515435

Loch J. \& Ethington R. 2017. An integrated trilobite and conodont biostratigraphy across the base of the Laurentian Whiterockian Series (lower Middle Ordovician) at its stratotype, Whiterock Canyon Narrows, Nevada. Journal of Paleontology 91: 294-317. https://doi.org/10.1017/jpa.2016.127

Maletz J. \& Bates D.E.B. 2017. Paleoecology of the Pterobranchia. In: Maletz J. (ed.) Graptolite Paleobiology: 50-57. John Wiley \& Sons Ltd, New York.

https://doi.org/10.1002/9781118515624.ch4

Marek J., Weber B., Schönian F., Egenhoff S.O. \& Erdtmann D. 2000. Arenig cephalopods from Bolivia. In: Cockle P., Wilson G., Brock G., Engelbretsen M., Simpson A. \& Winchester-Seeto T. (eds) Palaeontology Down Under 2000, Geological Society of Australia, Abstracts: 56. Geological Society of Australia, Sydney.

Miller A.K. \& Youngquist W. 1949. The Maquoketa Coquina of Cephalopods. Journal of Paleontology 23: 199-204.

Mutvei H. 2015. Characterization of two new superorders Nautilosiphonata and Calciosiphonata and a new order Cyrtocerinida of the subclass Nautiloidea; siphuncular structure in the Ordovician nautiloid Bathmoceras (Cephalopoda). GFF 137: 164-174. https://doi.org/10.1080/11035897.2015.1061592

Peterman D.J., Barton C.C. \& Yacobucci M.M. 2019. The hydrostatics of Paleozoic ectocochleate cephalopods (Nautiloidea and Endoceratoidea) with implications for modes of life and early colonization of the pelagic zone. Palaeontologia Electronica 22: 1-29. https://doi.org/10.26879/884

Pielou E.C. 1966. The measurement of diversity in different types of biological collections. Journal of Theoretical Biology 13: 131-144. https://doi.org/10.1016/0022-5193(66)90013-0

Piepjohn K., Dallmann W.K. \& Elvevold S. 2019. The Lomfjorden Fault Zone in eastern Spitsbergen (Svalbard). In: Piepjohn K., Strauss J.V., Reinhardt L. \& McClelland W.C. (eds) Circum-Arctic Structural Events: Tectonic Evolution of the Arctic Margins and Trans-Arctic Links with Adjacent Orogens: 95152. Geological Society of America, Boulder, CO. https://doi.org/10.1130/2019.2541(06)

Pohle A., Kröger B., Warnock R.C.M., King A.H., Evans D.H., Aaubrechtová M., Cichowolski M., Fang X. \& Klug C. (submitted). Bayesian inference of early cephalopod phylogeny - posterior clade supports and tree similarities in fossil datasets. BMC Biology.

Pruss S.B., Finnegan S., Fischer W.W. \& Knoll A.H. 2010. Carbonates in skeleton-poor seas: new insights from Cambrian and Ordovician strata of Laurentia. Palaios 25: 73-84.

https://doi.org/10.2110/palo.2009.p09-101r

Raatz W.D. \& Ludvigson G.A. 1996. Depositional environments and sequence stratigraphy of Upper Ordovician epicontinental deep water deposits, eastern Iowa and southern Minnesota. Geological Society of America, Special Paper 306: 143-159. https://doi.org/10.1130/0-8137-2306-X.143

Rasmussen C.M.Ø., Kröger B., Nielsen M.L. \& Colmenar J. 2019. Cascading trend of Early Paleozoic marine radiations paused by Late Ordovician extinctions. Proceedings of the National Academy of Sciences 116 (15): 7207-7213.. https://doi.org/10.1073/pnas.1821123116 
Rasmussen J.A. \& Stouge S. 1995. Late Arenig - early Llanvirn conodont biofacies acrosse the Iapetus Ocean. In: Cooper J.D., Droser M.L. \& Finney S.C. (eds) Ordovician Odyssey: Short Papers for the Seventh International Symposium on the Ordovician System: 443-447. SEPM Pacific section, Las Vegas.

Rüdiger H. 1889. Ueber die Silur-Cephalopoden aus den Mecklenburgischen Diluvialgeschieben. Rathsbuchdruckerei von C. Michaal \& A. Schuster, Güstrow, Germany.

https://doi.org/10.5962/bhl.title.14078

Ruedemann R. 1906. Cephalopoda of the Beekmantown and Chazy formations of the Champlain Basin. New York State Museum Bulletin 90: 393-611.

Salad Hersi O., Nowlan G.S. \& Lavoie D. 2007. A revision of the stratigraphic nomenclature of the Cambrian-Ordovician strata of the Philipsburg tectonic slice, southern Quebec. Canadian Journal of Earth Sciences 44: 1775-1790. https://doi.org/10.1139/e07-041

Serpagli E. \& Gnoli M. 1977. Upper Silurian cephalopods from southwestern Sardinia. Bollettino della Società Paleontologica Italiana 16: 153-196.

Servais T., Lehnert O., Li J., Mullins G.L., Munnecke A., Nützel A. \& Vecoli M. 2008. The Ordovician Biodiversification: revolution in the oceanic trophic chain. Lethaia 41: 99-109.

https://doi.org/10.1111/j.1502-3931.2008.00115.x

Smith M.P. \& Rasmussen J.A. 2008. Cambrian-Silurian development of the Laurentian margin of the Iapetus Ocean in Greenland and related areas. Geological Society of America, Memoirs 202: 137-167. https://doi.org/10.1130/2008.1202(06)

Stigall A.L., Edwards C.T., Freeman R.L. \& Rasmussen C.M.Ø. 2019. Coordinated biotic and abiotic change during the Great Ordovician Biodiversification Event: Darriwilian assembly of early Paleozoic building blocks. Palaeogeography, Palaeoclimatology, Palaeoecology 530: 249-270.

https://doi.org/10.1016/j.palaeo.2019.05.034

Stouge S.S. 1984. Conodonts of the Middle Ordovician Table Head Formation, western Newfoundland. Fossil and Strata 16: 1-145.

Sweet W.C. 1964. Oncocerida. In: Moore R.C. (ed.) Treatise on Invertebrate Paleontology, Part K, Mollusca 3: K277-K319. Geological Society of America and the University of Kansas Press, Boulder, Colorado.

Teichert C. 1964. Endoceratoidea. In: Moore R.C. (ed.) Treatise on Invertebrate Palaeontology, Part K, Mollusca 3: K160-K189. Geological Society of America and the University of Kansas Press, Boulder, Colorado.

Teichert C. 1969. Names and authorship of some cephalopod orders. Journal of Paleontology 43: 561562.

Teichert C. \& Glenister B.F. 1954. Early Ordovician cephalopod fauna from northwestern Australia. Bulletins of American Paleontology 35: 7-112.

Teichert C., Kummel B., Sweet W.C., Stenzel H.B., Furnish W.M., Glenister B.F., Erben H.K., Moore R.C. \& Nodine Zeller D.E. 1964. Cephalopoda - General Features - Endoceratoidea Actinoceratoidea - Nautiloidea - Bactritoidea. In: Moore R.C. (ed.) Treatise on Invertebrate Paleontology, Part K, Mollusca 3. Geological Society of America and the University of Kansas Press, Boulder, Colorado.

Trotter J.A., Williams I.S., Barnes C.R., Lécuyer C. \& Nicoll R.S. 2008. Did cooling oceans trigger Ordovician biodiversification? Evidence from conodont thermometry. Science 321: 550-554.

https://oi.org/10.1126/science.1155814 
Ulrich E.O., Foerste A.F., Miller A.K. \& Furnish W.M. 1942. Ozarkian and Canadian cephalopods: Part I: Nautilicones. Geological Society of America Special Papers 37: 1-157. https://doi.org/10.1130/SPE37-p1

Ulrich E.O., Foerste A.F. \& Miller A.K. 1943. Ozarkian and Canadian cephalopods. Part II. Brevicones. Geological Society of America Special Papers 59: 1-240. https://doi.org/10.1130/SPE49-p1

Ulrich E.O., Foerste A.F., Miller A.K. \& Unklesbay A.G. 1944. Ozarkian and Canadian cephalopods. Part III: Longicones and summary. Geological Society of America Special Papers 58: 1-226. https://doi.org/10.1130/SPE58

Wade M. 1988. Nautiloids and their descendants: cephalopod classification in 1986. New Mexico Bureau of Mines and Mineral Resources, Memoir 44: 15-25.

Westermann G.E.G. 1973. Strength of concave septa and depth limits of fossil cephalopods. Lethaia 6: 388-401. https://doi.org/10.1111/j.1502-3931.1973.tb01205.x

Westermann G.E.G. 1998. Life habits of nautiloids. In: Savazzi E. (ed.) Functional Morphology of the Invertebrate Skeleton: 263-298. John Wiley \& Sons, Chichester, New York.

Wheeley J.R., Jardine P.E., Raine R.J., Boomer I. \& Smith M.P. 2018. Paleoecologic and paleoceanographic interpretation of $\delta^{18} \mathrm{O}$ variability in Lower Ordovician conodont species. Geology 46: 467-470. https://doi.org/10.1130/G40145.1

Wolberg D.L. 1991. Notice of transfer of fossils from the New Mexico Bureau of Mines Rousseau H. Flower collections. Journal of Paleontology 65: 698-698.

https://doi.org/10.1017/S002233600003081X

Xiao C., Chen Z., Liu L. \& He Y. 2006. Ordovician cephalopod biofacies of South China and its provincialization. Journal of China University of Geosciences 17: 221-230.

https://doi.org/10.1016/S1002-0705(06)60031-9

Xu G.-H. \& Lai C.-G. 1987. Cephalopods. In: Wang X., Ni S., Zeng Q. et al. (eds) Biostratigraphy of the Yangtze Gorge Area, Volume 2, Early Palaezoic Area: 245-253. Geological Publishing House, Bejing.

Zhou Z.-Q. \& Zhou Z.-Y. 2019. Ordovician trilobites from the lower part of the Dawan Formation (Floian-Dapingian) at Huanghuachang, Yichang, Hubei, southern China. Palaeoworld 28 (1-2): 145165. https://doi.org/10.1016/j.palwor.2018.12.006

Zhuravleva F.A. 1994. The order Dissidocerida (Cephalopoda). Paleontological Journal 28: 115-132.

Manuscript received: 25 May 2021

Manuscript accepted: 1 October 2021

Published on: 20 December 2021

Topic editor: Christian de Muizon

Desk editor: Pepe Fernández

Printed versions of all papers are also deposited in the libraries of the institutes that are members of the EJT consortium: Muséum national d'histoire naturelle, Paris, France; Meise Botanic Garden, Belgium; Royal Museum for Central Africa, Tervuren, Belgium; Royal Belgian Institute of Natural Sciences, Brussels, Belgium; Natural History Museum of Denmark, Copenhagen, Denmark; Naturalis Biodiversity Center, Leiden, the Netherlands; Museo Nacional de Ciencias Naturales-CSIC, Madrid, Spain; Real Jardín Botánico de Madrid CSIC, Spain; Zoological Research Museum Alexander Koenig, Bonn, Germany; National Museum, Prague, Czech Republic. 


\section{Supplementary files}

Supp. file 1. List of straight and curved cephalopod specimens from the Olenidsletta Member, adjacent to Hinlopenstretet, Spitsbergen with measurements. Abbreviations and explanation of column names: working_number $=$ number given to specimen prior to inventory; FMNH specimen $=$ Finnish Museum of Natural History paleontological collection number of specimen; coll = collection $(\mathrm{mac}=$ macro, mic $=$ micro specimen); tax_nr = number of taxon; bed = bed number in locality PO; $w 1=$ conch width at position $1 ; \mathrm{w} 2=$ conch width at position $2 ; \mathrm{h} 1=$ conch height at position $1 ; \mathrm{h} 2=$ conch height at position $2 ; 1=$ distance between position 1 and 2 ; dsipho = diameter of siphuncle; $\mathbf{s}$ at $=$ conch height at position of measurement of dsipho; sdist $=$ distance of connecting ring from conch margin; sdist at $=$ conch height at position of measurement of sdist; $\mathrm{ch}=$ chamber length; $\mathrm{ch} \_$at $=$conch height at position of measurement of ch; anndist $=$ distance of annuli; anndepth $=$ amplitude height of annulation; a_at $=$ conch height at position of measurement ofanndist and anndepth; liraa = number of lira/striae; dist $=$ length of interval with liraa; 1 at $=$ conch height at position of measurement of liraa; sph $d=$ diameter of spherical apex; sph_l = length of speherical apex; con = diameter of apical constriction. All measurements in mm. https://doi.org/10.5852/ejt.2021.783.1601.5633

Supp. file 2. List of coiled cephalopod specimens from the Olenidsletta Member, adjacent to Hinlopenstretet, Spitsbergen with measurements. Abbreviations and explanation of column names: working_number $=$ number given to specimen prior to inventory; FMNH specimen $=$ Finnish Museum of Natural History paleontological collection number of specimen; $\mathrm{dm} 1=$ larger conch diameter; $\mathrm{dm} 2=$ smaller conch diameter; $\mathrm{uw}=$ umbilocal width; $\mathrm{iz}=$ imprint zone; $\mathrm{wh}=$ whorl height; $\mathrm{ww}=$ whorl width, $\mathrm{ds}=$ siphuncular diameter; ds_at $=$ whorl height at position of measurement of ds; sdist = distance of connecting ring from venter; $\overline{a h}=$ apertural height; $w h 2=$ second measurement of whorl height; wh $3=$ third measurement of whorl height, distance between measurements of whorl height $360^{\circ}$. https://doi.org/10.5852/ejt.2021.783.1601.5635

Supp. file 3. Character matrix for cladistic analysis see Pohle et al. (submitted) for details and explanation. https://doi.org/10.5852/ejt.2021.783.1601.5637 